OAK RIDGE

NATIONAL

LABORATORY

MARTIN MARUETTA
Evaluation of Dry-Solids-Blend Material Source for Grouts Containing 106-AN Waste: September 1990 Progress Report

T. M. Gilliam

S. C. Osborne

C. L. Francis

T. C. Scott 
This report has been reproduced directly from the best available copy.

Available to DOE and DOE contractors from the Otfice of Scientific and Technical Information, P.O. Box 62, Oak Ridge, TN 37831; prices available from (615) 576-8401, FTS 626-8401.

Available to the public from the National Trechnical Information Service, U.S. Department of Commerce, 5285 Port Royal Rid., Springfiuld, VA 22161.

This report was prepared as an account of work sponsored by an agency of the United States Government. Neither the United States Government nor any agency thereof, nor any of their employees, makes any warranty, express or implied, or assumes any legal liability or responsibility for the accuracy, completeness, or usefulness of any information, apparatus, product, or process disclosed, or represents that its use would not infringe privately owned rights. Reference herein to any specific commercial product, process, or service by trade name, trademark, manufacturer, or otherwise, does not necessarily constitute or imply its endorsement, recommendation, or favoring by the United States Government or any agency thereof. The views and opinions of authors expressed herein do not necessarily state or reflect those of the United States Government or any agency thereot. 
Chemical Technology Division

EVALUATION OF DRY-SOLIDS-BLEND MATERIAL SOURCE FOR GROUTS CONTAINING 106-AN WASTE: SEPTEMBER 1990 PROGRESS REPORT

T. M. Gilliam

S. C. Osborne

C. L. Francis

T. C. Scott

Date Published-September 1993

Prepared for Westinghouse Hanford Company

(Activity No. GF 7101864 )

Prepared by the

OAK RIDGE NATIONAI LABORATORY

Oak Ridge, Tennessee 37831

mainaged by

MARTIN MARIETTA ENERGY SYSTEMS, INC.

for the

U.S. DEPARTMENT OF ENERGY

under contract DE-AC05-84OR21400 


\section{CONTENTS}

LIST OF TABLES $\ldots \ldots \ldots \ldots \ldots \ldots \ldots \ldots \ldots \ldots \ldots \ldots \ldots \ldots \ldots \ldots$

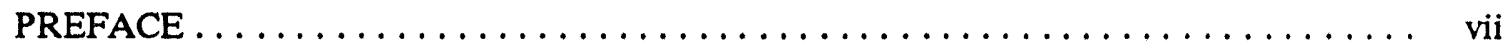

EXECUTIVE SUMMARY $\ldots \ldots \ldots \ldots \ldots \ldots \ldots \ldots \ldots \ldots \ldots \ldots \ldots \ldots \ldots$

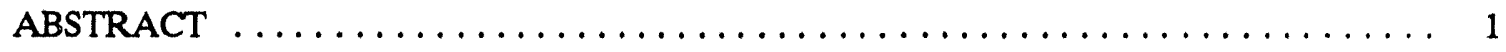

1. INTRODUCTION $\ldots \ldots \ldots \ldots \ldots \ldots \ldots \ldots \ldots \ldots \ldots \ldots \ldots \ldots \ldots \ldots$

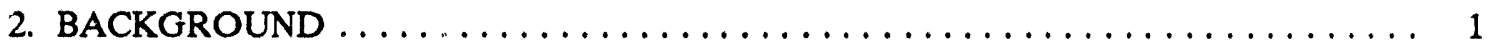

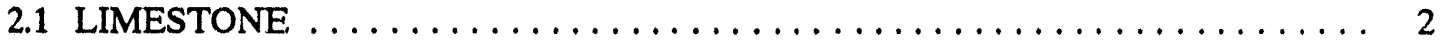

2.2 GRANULATED-BLAST FURNACE SLAG $\ldots \ldots \ldots \ldots \ldots \ldots \ldots \ldots \ldots$

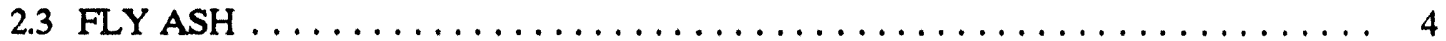

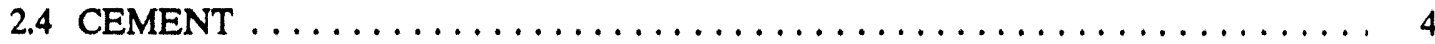

2.5 IMPACT ON MATERIAL SOURCE SELECTION $\ldots \ldots \ldots \ldots \ldots \ldots \ldots \ldots 5$

3. SELECTION OF DRY-SOLIDS-BLEND MATERIAL SOURCE $\ldots \ldots \ldots \ldots \ldots \ldots$

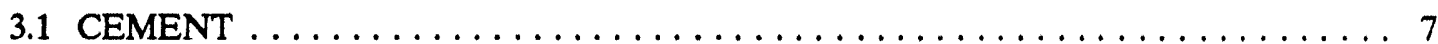

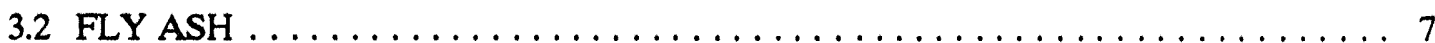

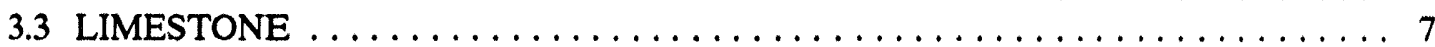

3.4 GRANULATED-BLAST FURNACE SLAG $\ldots \ldots \ldots \ldots \ldots \ldots \ldots \ldots$

4. METHODOLOGY FOR EVALUATION OF GROUT PROPERTIES . . . . . . . . . . 9

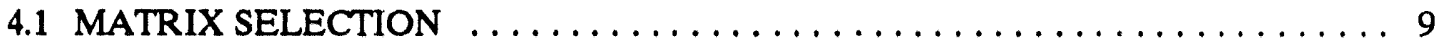

4.2 SAMPLE PREPARATION PROCEDURE $\ldots \ldots \ldots \ldots \ldots \ldots \ldots \ldots \ldots \ldots \ldots$

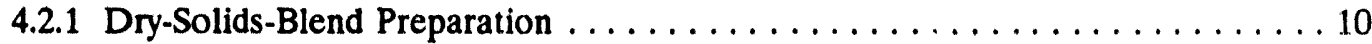

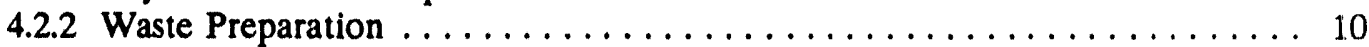

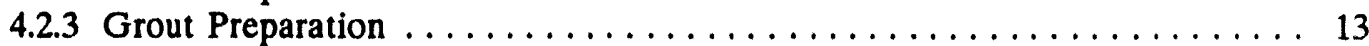

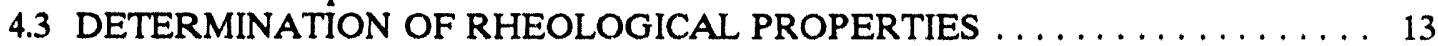

4.4 DETERMINATION OF SOLID-GROUT PROPERTIES $\ldots \ldots \ldots \ldots \ldots \ldots \ldots \ldots$

4.4.1 Unconfined Compressive Strength $\ldots \ldots \ldots \ldots \ldots \ldots \ldots \ldots \ldots \ldots$

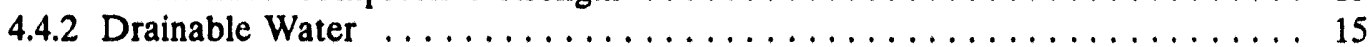

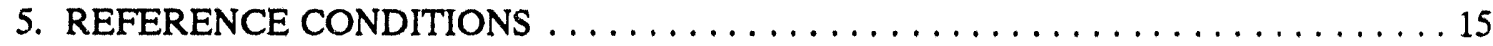

6. STATISTICAL ANALYSIS TO DETERMINE EFFECTS OF MATERIAL SOURCE . 21

6.1 APPROACH UTILIZED IN STATISTICAL ANALYSIS $\ldots \ldots \ldots \ldots \ldots \ldots \ldots 21$

6.2 COMPARISON OF REFERENCE FORMULATION TREATMENTS $\ldots \ldots \ldots \ldots 22$

6.3 APPLICATION TO FIELD OPERATION $\ldots \ldots \ldots \ldots \ldots \ldots \ldots \ldots \ldots \ldots$

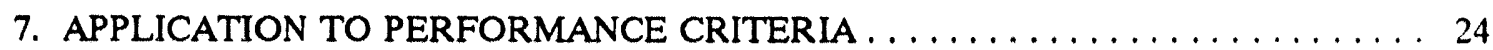

7.1 COMPARISON OF MATRIX CHARACTERISTIC VALUFS $\ldots \ldots \ldots \ldots \ldots \ldots$

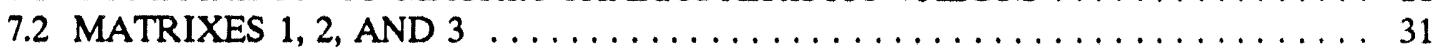




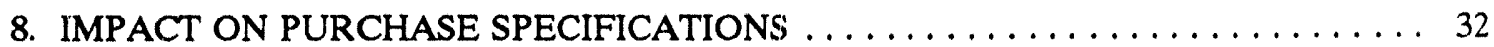

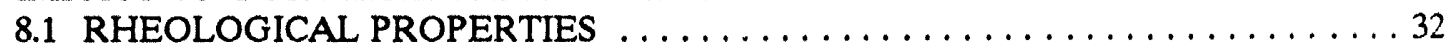

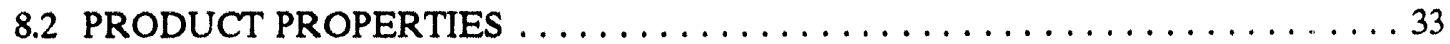

9. SUMMARY AND RECOMMENDATIONS $\ldots \ldots \ldots \ldots \ldots \ldots \ldots \ldots \ldots \ldots$

10. ACKNOWLEDGMENT $\ldots \ldots \ldots \ldots \ldots \ldots \ldots \ldots \ldots \ldots \ldots \ldots \ldots \ldots \ldots \ldots \ldots$

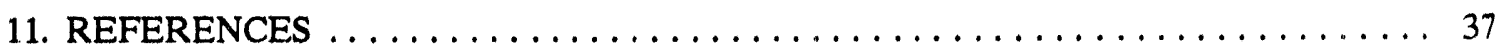

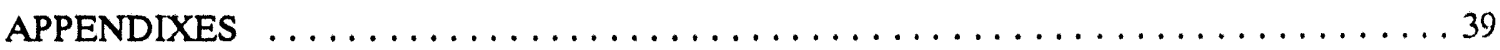

Appendix A. CHARACTERIZATION OF DRY-SOLIDS-BLEND

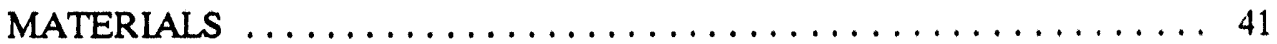

Appendix B. ADDITIONAL MATERIAL CHARACTERIZATION DATA . . . . . . 55

Appendix C. GROUT FORMULATIONS USED IN EXPERIMENTAL

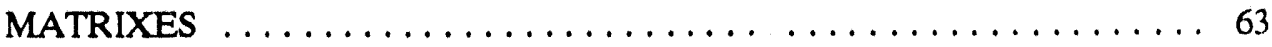

Appendix D. FLUID-GROUT DATA FOR ALL EXPERIMENTAL RUNS $\ldots \ldots \ldots \ldots 81$

Appendix E. DRAINABLE-WATER DATA FOR ALL EXPERIMENTAL

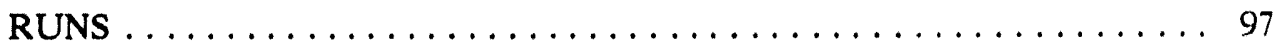

Appendix F. UNCONFINED-COMPRESSIVE-STRENGTH DATA FOR

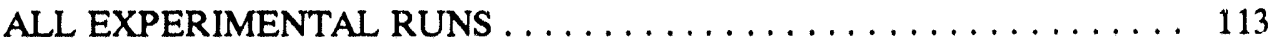

Appendix G. AVERAGED FLUID-PROPERTY DATA . . . . . . . . . . . . . . 129

Appendix $H . \quad$ AVERAGED DRAINABLE-WATER DATA $\ldots \ldots \ldots \ldots \ldots \ldots \ldots 145$

Appendix I. AVERAGED UNCONFINED-COMPRESSIVE-STRENGTH

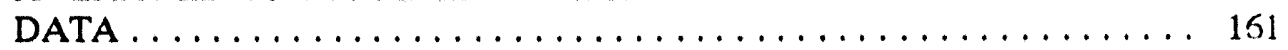

Appendix J. STATISTICAL COMPARISON OF AVERAGE DATA OBTAINED ON REFERENCE FORMULATION $\ldots \ldots \ldots \ldots \ldots \ldots 177$

Appendix K. STATISTICAL COMPARISON OF DATA OBTAINED BY AVERAGING ALL DATA WITHIN A MATRIX 


\section{List of Tables}

Table

$\underline{\text { Page }}$

1. Basic matrix used for comparison of grouts prepared from various sources of material $\ldots \ldots \ldots \ldots \ldots \ldots \ldots \ldots \ldots \ldots \ldots \ldots$

2. Basic matrix (converted to typical units) used for comparison of grouts prepared from various sources of material $\ldots \ldots \ldots \ldots \ldots \ldots \ldots \ldots \ldots$

3. Dry-solids-blend components used in each matrix $\ldots \ldots \ldots \ldots \ldots \ldots \ldots \ldots \ldots \ldots$

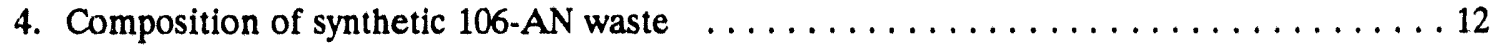

5. Data for critical velocity obtained from reference formulations $\ldots \ldots \ldots \ldots \ldots \ldots \ldots 16$

6. Data for $10-\mathrm{min}$ gel strength obtained from reference formulation $\ldots \ldots \ldots \ldots \ldots 17$

7. Data for $28-\mathrm{d}$ drainable water obtained from reference formulation $\ldots \ldots \ldots \ldots \ldots 18$

8. Data for $28-d$ unconfined compressive strength obtained from reference formulation $\ldots 19$

9. F-test and Q-test values in reference formulation from 11 matrixes $\ldots \ldots \ldots \ldots \ldots 23$

10. F-test and Q-test values for matrix average characteristics $\ldots \ldots \ldots \ldots \ldots \ldots \ldots 25$

11. Data for critical velocity obtained from all matrix values $\ldots \ldots \ldots \ldots \ldots \ldots \ldots 27$

12. Data for 10 -min gel strength obtained from all matrix values $\ldots \ldots \ldots \ldots \ldots \ldots \ldots$

13. Data for 28 -d drainable water obtained from all matrix values $\ldots \ldots \ldots \ldots \ldots \ldots \ldots 29$

14. Data for 28 -d unconfined compressive strength obtained from all matrix values $\ldots \ldots \ldots 30$ 


\section{PREFACE}

This report meets requirements for Milestone 3.5, "Report Recommended Purchase Specifications for Each of Dry Materials," and Milestone 3.6, "Report Results of the Impact on Waste-Form Properties of Dry Materials Source," as described in Statement of Work (SOW) TMG-SOW-90, Revision No. 1, in support of the Westinghouse Hanford Grout Disposal Program. It should be noted that funding reductions, which occurred during the course of this work, reduced the scope of the project. Consequently, the recommendations presented in this report must be considered preliminary, pending additional data scheduled for acquisition in fiscal year 1991. 


\section{EXECUTTVE SUMMARY}

Stabilization/solidification (S/S) is the most widely used technology for the treatment and ultimate disposal of both radioactive and chemically hazardous wastes. Cement-based products, commonly referred to as grouts, are the predominant materials of choice because of their associated low processing costs, compatibility with a wide variety of disposal scenarios, and ability to meet stringent processing and performance requirements.

Such technology is being utilized in a Grout Treatment Facility (GTF) by the Westinghouse Hanford Company (WHC) for the disposal of various wastes, including 106-AN wastes, located on the Hanford Reservation. The WHC personnel have developed a grout formula for 106-AN disposal that is designed to meet stringent performance requirements. This formula consists of a dry-solids blend containing $40 \mathrm{wt} \%$ limestone, $28 \mathrm{wt} \%$ granulated blast furnace slag (BFS), 28 wt \% ASTM Class F fly ash, and 4 wt \% Type I-II-LA Portland cement. The blend is mixed with 106-AN waste at a ratio of $9 \mathrm{lb}$ of dry-solids blend per gallon of waste. This report documents progress made to date on efforts at Oak Ridge National Laboratory (ORNL) in support of WHC's Grout Technology Program to assess the effects of the source of the dry-solids-blend materials on the resulting grout formula.

Numerous sources of dry-solids-blend materials were obtained. Grouts were prepared with various combinations of these materials and synthetic 106-AN waste. The composition of the grout formula was varied in such a manner as to produce a matrix of grouts for each component combination designed to represent the population of variations expected during operation of the GTF. The following characteristics of cach grout formulation were determined: critical velocity, frictional pressure drop, 10-min gel strength, fluid density, 28-d unconfined compressive strength, and 28-d drainable water. Based on a comparison of the average characteristics of the reference formulation and the matrix population, it has been determined that there is a statistically significant difference in all measured grout characteristics because of the source of the dry-solids-blend components.

Significantly, all grouts evaluated in this report met GTF performance requirements with regard to critical velocity, frictional pressure drop, 10-min gel strength, and 28 -d unconfined compressive strength. Thus, although the source of material affects these grout properties, the impact is not significant relative to the performance that would be desired or expected, based on these properties. However, this conclusion does not apply to 28-d drainable water. Average values for the reference formulation and the matrix routinely exceeded the performance criterion of 5 vol \% drainable water. Only the data obtained from Matrixes 1, 6, 7, and 12 met this 
criterion with any degree of confidence. Matrixes 1 and 12 contained limestone flour and BFS S-8, while matrixes 6 and 7 contained limestone flour and BFS S-13. Matrixes 1 and 12 also varied the source of cement, while Matrixes 6 and 7 varied the source of fly ash. Thus, it can be inferred that the sources of cement and fly ash do not play a major role in controlling drainable water when used with limestone flour and either BFS S-8 or S-13.

Assuming that the control of drainable water is due, in large part, to the sorption or wetting of the limestone, then, logically, the use of limestone flour with its smaller particle size and, hence, larger surface area, as compared with the ground limestone, should prove beneficial in controlling drainable water. A comparison of average data for 28-d drainable water from Matrixes 4 and 10 supports this premise. The components in Matrixes 4 and 10 are identical except that Matrix 4 used limestone flour, while Matrix 10 used ground limestone. The average value of 28 -d drainable water for Matrix 4 was 5.8 vol \%, while that for Matrix 10 was $8.2 \mathrm{vol} \%$.

This sensitivity of drainable water with respect to the surface area of limestone within ASTM Class $T$ designation has potentially serious implications on both plant operation and material purchase specifications. Requiring a finer grind of limestone beyond that consistent with ASTM C 602.69 will definitely increase its cost. In addition, without significant additional development effort, neither the acceptable range in particle-size distribution to be used as a purchase specification nor a correlation between particle-size distribution and drainable water can be estaolished. Such a developmental effort is not consistent with budget and schedule constraints. Thus, it can be assumed that, because of differences in particle-size distribution, the plant will experience variations in drainable water from batch to batch of limestone flour. At present, the size of these variations must be considered unknown. It can only be assumed that if the purchase specifications for limestone flour are made consistent with the material used in this study, then the drainable water criterion should be met the majority of the time.

Significantly, the limestone flour controlled the values for 28 -d drainable water to within desired limits only in combination with BFS S-8 and S-13. The cause of this synergistic effect is unknown at present. Blaine fineness values for S-8 and S-13, 390 and $567 \mathrm{~m}^{2} / \mathrm{kg}$, respectively, essentially bracket the values for the other BFSs tested. Thus, the synergistic effect is apparently not related to the particle size or the grade of the BFS. Some other, as yet to be identified, characteristic of the BFS appears to be the underlying cause. Clearly, efforts to be conducted during the next fiscal year should focus on a detailed characterization of the BFSs and their impact on drainable water. 


\title{
EVALUATION OF DRY-SOLIDS-BLEND MATERIAL SOURCE FOR GROUTS CONTAINING 106-AN WASTE: SEPTEMBER 1990 PROGRESS REPORT
}

T. M. Gilliam

S. C. Osborne

C. L. Francis

T. C. Scott

\begin{abstract}
This report documents progress made to date on the evaluation of dry-solids-blend material source and the subsequent impact on waste-form performance criteria. The evaluation is intended to provide documentation in support of purchase specifications for individual dry-solids-blend components.
\end{abstract}

\section{INTRODUCTION}

Stabilization/solidification (S/S) is the most widely used technology for the treatment and ultimate disposal of both radioactive and chemically hazardous wastes. Cement-based products, commonly referred to as grouts, are the predominant materials of choice because of their associated low processing costs, compatibility with a wide variety of disposal scenarios, and ability to meet stringent processing and performance requirements.

Such technology is being utilized in a Grout Treatment Facility (GTF) by the Westinghouse Hanford Company (WHC) for the disposal of various wastes, including 106-AN wastes, located on the Hanford Reservation. The WHC personnel have developed a grout formula for the 106-AN disposal that is designed to meet stringent performance requirements. This formula consists of a dry-solids blend containing $40 \mathrm{wt} \%$ limestone, $28 \mathrm{wt} \%$ granulated blast furnace slag (BFS), 28 wt \% ASTM Class F fly ash, and 4 wt \% Type I-II-LA Portland cement. The blend is mixed with 106-AN waste at a ratio of $9 \mathrm{lb}$ of dry-solids blend per gallon of waste. This report documents progress made to date on efforts at Oak Ridge National Laboratory (ORNL) in support of WHC's Grout Technology Program to assess the effects of the source of the dry-solids-blend materials on the resulting grout formula.

\section{BACKGROUND}

The grout is to be used in Westinghouse Hanford's GTF, where the dry-solids-blend materials are combined with specified volumes of waste in equipment located adjacent to the waste storage tanks. The resulting fresh grout is then pumped to a permanent disposal site 
where it hardens and forms an engineered barrier protecting against the intrusion of groundwater and subsequent release of the waste constituents of concern. As such, the grout must meet stringent process and product performance criteria such as:

\section{Product Performance Criteria}

Unconfined compressive strength, $>60$ psi after $28 \mathrm{~d}$

Drainable water, $\leq 5$ vol $\%$ after $28 \mathrm{~d}$

\section{Process Performance Criteria (based on nominal 2-in. schedule 80 pipe)}

Frictional pressure drop, $<14 \mathrm{psi} / 100 \mathrm{ft}$

Ten-minute gel strength, $<100 \mathrm{lb}_{\mathrm{f}} / 100 \mathrm{ft}^{2}$

Critical velocity, $<60 \mathrm{gpm}$

It is essential that the dry-solids-blend components be of sufficient quality to meet these requirements when combined to form the grout, and it is economically desirable that these materials be available from as many commercial sources as possible. The four dry-solids-blend components (limestone, fly ash, granulated BFS, and cement) are generic materials produced by numerous commercial vendors, and each can be characterized by well established ASTM standards.

\subsection{LIMESTONE}

Limestone is added to the grout as an inert material to minimize the heat liberated during the curing process. As such, it adds little to the final strength or durability of the grout product; however, it may contribute to the fluidity of freshly prepared grouts at elevated temperatures. Limestone is an agricultural liming material whose calcium and magnesium compounds are capable of neutralizing soil acidity. As such, it can be characterized by ASTM $C$ 602-69, "Standard Specification for AGRICULTURAL LIMING MATERIALS." As an essentially chemically pure material $\left(\mathrm{CaCO}_{3}\right)$, the standard specifies that limestone be classified according to its size distribution. Principal classification specifications are as follows:

\begin{tabular}{ccc}
$\begin{array}{c}\text { Class } \\
\text { designation }\end{array}$ & $\begin{array}{c}\text { Passing No. 8 sieve } \\
(\text { min. \%) }\end{array}$ & $\begin{array}{c}\text { Passing No. 60 sievc } \\
(\text { min. \%) }\end{array}$ \\
\cline { 2 - 3 } S & 100 & 100 \\
T & 99 & 75 \\
O & 95 & 55 \\
N & 90 & 40 \\
E & 80 & 25
\end{tabular}

In addition, the limestone shall have a "calcium carbonate equivalent" of not less than $80 \%$. 


\subsection{GRANULATED BLAST-FURNACE SLAG}

BFS is added to the grout primarily due to its redox potential and its corresponding ability to reduce $\mathrm{Tc}(\mathrm{VII})$ to $\mathrm{Tc}(\mathrm{IV})$, which is significantly less mobile. In addition, BFS has cementitious properties and may result in a product with a finer microstructure than that exhibited by simple cement paste. The molten material forms a glassy, granular material on being rapidly chilled, as by immersion in water. It can be used as an additive for construction. grade concrete and can be characterized by ASTM C 989.88, "Standard Specification for GROUND GRANULATED BLAST-FURNACE SLAG FOR USE IN CONCRETE AND

MORTARS." As described in ASTM C989-88, the principal characteristics of granulated BFS are as follows:

\section{General properties}

Amount retained when wet screened on a $45-\mu \mathrm{m}$ (No. 325) sieve, max. \%

Air content of slag mortar, max. \%

Sulfide sulfur, max. \%

Sulfate ion reported as $\mathrm{SO}_{3}$, max. \%

4.0

\section{Grade-specific properties}

Average o:

last five

consecutive

samples

Any individual sample

Slag activity index, $\min . \%$

7-d index

Grade 80

Grade 100

NR*

75

Grade 120

90

INR"

70

28-d index

Grade 80

75

Grade 100

95

70

Grade 120

115

90

110

${ }^{\mathrm{a}}$ No requirement specified. 
In effect, granulated BFS, hereafter referred to as BFS, is also classified according to size distribution or grade. That is, the higher the grade classification, the smaller the particle size.

\section{FLY ASH}

Fly ash is added to the grout for a variety of reasons. It minimizes the $\mathrm{CaOH}$ content of the final grout product, reduces the heat liberated during curing (by substitution of BFS and cement), can undergo cementitious reactions when chemically or thermally activated, can increase the fluidity of fresh grouts, and can improve the final strength and microstructure of the product. Fly ash is used routinely as a mineral admixture in concrete for structural applications. As such, it can be characterized by ASTM C 618-85, "Standard Specification for FLY ASH AND RAW OR CALCINED NATURAL POZZOLAN FOR USE AS A MINERAL ADMIXTURE IN PORTLAND CEMENT CONCRETE." Fly ash is classified primarily by gross chemical composition as follows:

Characteristic

Silicon dioxide $\left(\mathrm{SiO}_{2}\right)$ plus aluminum oxide $\left(\mathrm{Al}_{2} \mathrm{O}_{3}\right)$

plus iron oxide $\left(\mathrm{Fe}_{2} \mathrm{O}_{3}\right)$, min. \%

Sulfur trioxide $\left(\mathrm{SO}_{3}\right), \max . \%$

Moisture content, $\max . \%$

Loss on ignition, $\max \%$

\begin{tabular}{ccc}
\multicolumn{3}{c}{ Classification } \\
\hline $\mathrm{N}$ & $\mathrm{F}$ & $\mathrm{C}$ \\
\hline
\end{tabular}

70.0

70.0

50.0

4.0

5.0

5.0

3.0

3.0

3.0

10.0

6.0

6.0

ASTM C618-85 specifications indirectly dictate allowable $\mathrm{CaO}$ content. In general, $\mathrm{CaO}$ is the primary constituent in fly ash beyond those specified in the standard. As such, Class $\mathrm{F}$ fly ash would have a significantly lower $\mathrm{CaO}$ content than does Class $\mathrm{C}$ fly ash; however, since it is not specified directly, the $\mathrm{CaO}$ content can vary within any individual fly-ash class.

\section{CEMENT}

Cement is added to the grout as the primary adhes monolithic product. It is a common construction material and can be characterized by 
ASTM C 150-84, "Standard Specification for PORTLAND CEMENT." This standard classifies cement primarily by its chemical composition as follows:

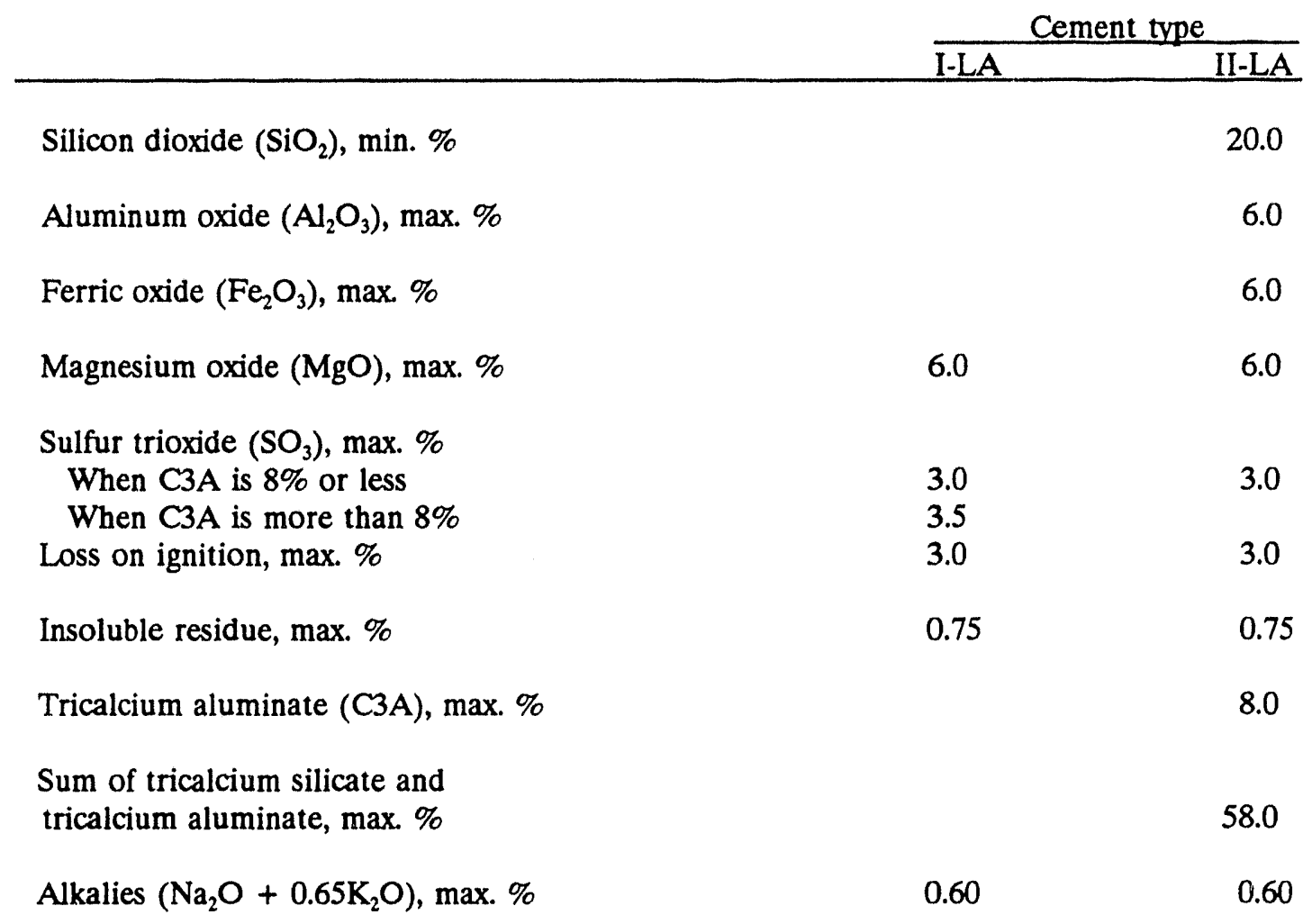

\subsection{IMPACT ON MATERIAL SOURCE SELECTION}

It is envisioned that a minimum purchase specification for each of the blend components will be consistent with basic applicable ASTM standards for the material (i.e., ASTM C602-69, ASTM C989-88, ASTM C618-85, and ASTM C150-84). As seen in Sects. 2.1 through 2.4, these basic specifications allow some variability in the characteristics of the material, particularly with respect to those materials that are waste materials per se (i.e., fly ash and BFS). Therefore, in selecting materials for evaluation, it was desired that sufficient sources of materials would be identified so as to address variability allowed by the basic ASTM standard. Specifically, this variability should include:

1. variations in particle-size distribution for limestone within a single-class designation,

2. variations in BFS grade from a single source, and

3. variation in $\mathrm{CaO}$ content for fly ash meeting Class $\mathrm{F}$ specifications. 
It should be noted that the basic ASTM cement specifications have historically proven to be adequate. Consequently, a large number of cement sources were not needed.

\section{SELECTION OF DRY-SOLIDS-BLEND MATERIAL SOURCE}

Known suppliers of the dry-solids-blend materials were contacted, and samples were requested for evaluation in this study. In order to limit the number of materials evaluated to meet budget and schedule commitments, the general operation of the GTF and its location were described to each vendor, and the following constraints were placed on material source:

1. The vendor must be able to supply material for two 1-million-gal disposal campaigns per year.

2. The material must meet applicable ASTM standards as described in Sect. 2.

3. If chosen as a supplier, the vendor must be willing to have its quality assurance program/procedures audited periodically by WHC personnel.

4. Considering the nature or use of the material (waste disposal) and the location of the GTF (Hanford Reservation), the vendor must believe that his material is a viable candidate for eventual use.

It was this last constraint that provided the limiting factor for the materials to be evaluated. As generic bulk materials, the greatest contributor to their ultimate cost is shipping/transportation. Typically, the associated transportation costs limit the source of these materials to a radius of approximately 500 miles from their final destination (Hanford). Since "local" sources of cement, fly ash, and limestone are available, vendors from other parts of the country did not feel that they would be economically competitive; however, as no "local" source of BFS exists, numerous vendors were willing to participate. Significantly, no vendor expressed concern over the fact that the materials would be used for waste disposal.

It is important for the reader to note that these constraints, believed to be realistic with respect to operation of the GTF, allowed the desires detailed in Sect. 2.5 to be met. That is, the materials evaluated encompassed variations allowed by the basic ASTM standards. Specifically, the materials received included:

1. a single-class designation of limestone with different particle-size distributions,

2. a single source of BFS at two different grades, and

3. ASTM Class $\mathrm{F}$ fly ash with different $\mathrm{CaO}$ contents.

The sources of materials used in this study are documented in the following sections. Additional characterization data are shown in Appendixes A and B. 
3.1 CEMENT

Type I-II-LA Portland cement was supplied by two vendors:

Ash Grove Cement West, Inc.

3801 East Marginal Way, South

Seattle, WA 98134

(hereafter referred to as C-88) and

Lafarge Corporation

N. 209 Havana Street

P. O. Box 13189

Spokane, WA $99213-3189$

(hereafter referred to as C-91)

\subsection{FLY ASH}

ASTM Class F fly ash was supplied by:

Pozzolanic International

7525 SE 24th Street

Suite 630

Mercer Island, WA 98040

Fly ash was supplied from two plants:

(1) Jim Bridger, hereafter referred to as P-56; and

(2) Centralia, hereafter referred to as P-55.

The CaO content of the Jim Bridger ash was on the order of $6 \mathrm{wt} \%$, while the Centralia fly ash had a $\mathrm{CaO}$ content on the order of $12 \mathrm{wt} \%$.

\subsection{LIMESTONE}

Limestone was supplied by:

Ash Grove Cement West, Inc.

P.O. Box 83007

St. Johns Station

Portland, Oregon 97283-0007

Two different grinds of material were received:

(1) ground limestone, hereafter referred to as P.58; and

(2) limestone flour, hereafter referred to as P.59.

Both of these materials would be classified as Class T in accordance with ASTM C 602-69. 


\subsection{GRANULATED BLAST-FURNACE SLAG}

As indicated previously, numerous potential sources of BFS were identified. The suppliers and their internal labels are as follows:

\begin{tabular}{|c|c|c|}
\hline Label & Description & Supplier \\
\hline S-6 & 5000 Blaine & $\begin{array}{l}\text { The Standard Slag Company } \\
1200 \text { Stambaugh Building } \\
\text { P.O. Box } 1378 \\
\text { Youngstown, Ohio } 44501\end{array}$ \\
\hline S-7 & 6000 Blaine & $\begin{array}{l}\text { The Standard Slag Company } \\
1200 \text { Stambaugh Building } \\
\text { P.O. Box } 1378 \\
\text { Youngstown, Ohio } 44501\end{array}$ \\
\hline S-8 & & $\begin{array}{l}\text { Ash Grove Cemeni West, Inc. } \\
3801 \text { East Marginal Way, South } \\
\text { Seattle, WA } 98134\end{array}$ \\
\hline S.9 & Grade 120 & $\begin{array}{l}\text { Blue Circle Atlantic, Inc. } \\
\text { P.O. Box } 3 \\
\text { Ravena, New Yurk } 12143\end{array}$ \\
\hline S-10 & Grade 100 & $\begin{array}{l}\text { Blue Circle Atlantic, Inc. } \\
\text { P.O. Box } 3 \\
\text { Ravena, New York } 12143\end{array}$ \\
\hline S-11 & 3720 Blaine & $\begin{array}{l}\text { C.T. Takahashi \& Co., Inc. } \\
\text { Bay Vista Building, Suite } 230 \\
2815 \text { Second Avenue } \\
\text { Seattle, WA } 98121\end{array}$ \\
\hline S-12 & 5060 Blaine & $\begin{array}{l}\text { C.T. Takahashi \& Co., Inc. } \\
\text { Bay Vista Building, Suite } 230 \\
2815 \text { Second Avenue } \\
\text { Seattle, WA } 98121\end{array}$ \\
\hline$S-13$ & 3910 Blaine & $\begin{array}{l}\text { Standard Slag Cement } \\
360 \text { Jones Road } \\
\text { Fruitland, Ontario LOR } 1 \text { LO }\end{array}$ \\
\hline S-14 & High Blaine & $\begin{array}{l}\text { Standard Slag Cement } \\
360 \text { Jones Road } \\
\text { Fruitland, Ontario LOR 1LO }\end{array}$ \\
\hline
\end{tabular}




\section{METHODOLOGY FOR EVALUATION OF GROUT PROPERTIES}

Ultimately, a method of determining the effect of the material source on subsequent properties of the grout prepared using that material was of major interest. In order to address this interest, it was desired to have an experimental matrix that encompassed the expected compositional variations of the material in the grout. Each matrix would be comprised of grouts made from materials from one source (per component). Data obtained from this matrix would be averaged, with the average being representative of the population (or material composition variations) encompassed by the matrix. This matrix would then be repeated using different material sources and the average values compared. Similar averages between matrices would indicate no significant differences in grout properties due to the material source. On the other hand, significant differences between the averages would indicate a dependency on material source. The same result could be achieved by comparing identical observations between matrixes. The data obtained as described in these sections are presented in Appendixes $\mathrm{C}$ through I.

\subsection{MATRIX SELECTION}

The matrix of interest must encompass the compositional variations associated with the dry-solids-blend materials that could be expected to occur during routine operation of the GTF. The range of interest that needs to be encompassed by the matrix is that of composition expected during the normal blending and mixing of limestone (A), fly ash (B), granulated BFS (C), and cement (D), and the mix ratio (E). The basic matrix chosen to evaluate these materials is a quarter of the full factorial for five variables. The basic matrix is shown in Table 1.

Table 1. Basic matrix used for comparison of grouts prepared from various sources of material

\begin{tabular}{cccccc}
\hline $\begin{array}{c}\text { Observation } \\
\text { No. }\end{array}$ & \multicolumn{5}{c}{ Variable $^{4}$} \\
\cline { 2 - 6 } & A & B & C & D & E \\
\hline 1 & - & - & - & + & - \\
2 & - & - & + & - & + \\
3 & - & + & - & - & + \\
4 & - & + & + & + & - \\
5 & + & - & - & + & + \\
6 & + & - & + & $\cdot$ & - \\
7 & + & + & - & - & - \\
8 & + & + & + & + & + \\
9 & R & R & R & R & R
\end{tabular}

- values, $90 \%$ of the reference value; + values, $110 \%$ of the reference value; $R$ values, reference blend composition. 
In this matrix, variables $A$ through $D$ reflect blend composition, while variable $E$ reflects mix ratio. Typically, these variables are thought to possess different units. Blend composition is routinely referred to as $w t \%$, while mix ratio is typically expressed in lb/gal. In reality, the GTF will measure all of these variables based on weight; thus, if the variables are selected based on 1 gal of waste, then all will be in units of pounds.

Based on 1 gal of waste, the reference blend composition ( $R$ ), in units of pounds, is as follows: limestone flour, 3.6; fly ash, 2.52; granulated BFS, 2.52; cement, 0.36; and mix ratio, 9. During routine operation of the GTF, the weight of individual blend components can be controlled $\pm 5 \%$, while the mix ratio can be controlled $\pm 0.5 \mathrm{lb}$ (on a per-gallon basis). Using this digree of control as a guideline, the "plus" values in the block for variables $A, B, C$, and D are $110 \%$ of the reference value, while "minus" values are $90 \%$ of the reference value. For variable $\mathrm{E}$, the plus value is 9.5 , while the minus value is 8.5 . Note that the variability of the blend components is greater than that expected during routine operation of the GTF.

For the reader's convenience, Table 2 presents the blend compositions (from Table 1 ) in more typical units. Table 3 presents the blend materials used in each matrix.

\subsection{SAMPLE PREPARATION PROCEDURE}

Prior to sample preparation for each matrix, the sources of materials were selected. These materials were then used for all blends in a particular matrix. The runs in each matrix were performed in a random order, with the order selected by drawing the numbers 1 through 9 out of a hat. In all data tables presented in this report, the run No. represents the order in which the experiment was performed; the observation No. relates the formulation used to Tables 1 and 2.

\subsubsection{Dry-Solids-Blend Preparation}

Predetermined weights of each blend component were added to a 3- $\mathrm{ft}^{3}$ Patterson-Kerlly twin-shell V-blender in sufficient quantity to accommodate sample requirements for all runs in a matrix. The materials were then tumbled for $23 \mathrm{~h}$. The resulting blended material became the dry-solids blend to be added to the waste in the grout preparation step.

\subsubsection{Waste Preparation}

Synthetic 106-AN waste of composition shown in Table 4 was prepared in sufficient quantity to accommodate all sample requirements for all runs in a matrix. The waste was

maintained at $50^{\circ} \mathrm{C}$ and continuously stirred for introduction to the grout preparation step. 
11

Table 2. Basic matrix (converted to typical units) used for comparison of grouts prepared from various sources of material

\begin{tabular}{|c|c|c|c|c|c|}
\hline \multirow{2}{*}{$\begin{array}{l}\text { Observation } \\
\text { No. }\end{array}$} & \multirow[b]{2}{*}{ Liniestone } & \multicolumn{3}{|c|}{ Blend composition (wt \%) } & \multirow{2}{*}{$\frac{\text { Mix ratlo }}{\text { (lb/gal) }}$} \\
\hline & & Fly ash. & BES & Cement & \\
\hline 1 & 39.63 & 27.76 & 27.76 & 4.84 & 8.5 \\
\hline 2 & 37.66 & 26.38 & 32.19 & 3.77 & 9.5 \\
\hline 3 & 37.66 & 32.19 & 26.38 & 3.77 & 9.5 \\
\hline 4 & 35.31 & 30.19 & 30.19 & 4.32 & 8.5 \\
\hline 5 & 44.51 & 25.52 & 25.52 & 4.45 & 9.5 \\
\hline 6 & 42.47 & 24.35 & 29.71 & 3.47 & 8.5 \\
\hline 7 & 42.47 & 29.71 & 24.35 & 3.47 & 8.5 \\
\hline 8 & 40.02 & 27.99 & 27.99 & 4.0 & 9.5 \\
\hline 9 & 40.0 & 28.0 & 28.0 & 4.0 & 9.0 \\
\hline
\end{tabular}

Table 3. Dry-solids-blend components used in each matrix

\begin{tabular}{|c|c|c|c|c|}
\hline $\begin{array}{l}\text { Matrix } \\
\text { No. }\end{array}$ & Limestone & Fly ash & Cement & BFS \\
\hline 1 & P.59 & P.55 & C-88 & S.8 \\
\hline 2 & P.5' & P.55 & C-88 & S.10 \\
\hline $2 \mathbf{R}$ & P.59 & P.55 & C.88 & S.10 \\
\hline 3 & P.59 & P.55 & C.88 & S.9 \\
\hline 4 & P.59 & P.55 & C.88 & S.6 \\
\hline 5 & P.59 & P.55 & C.88 & S.7 \\
\hline 6 & P.59 & P.55 & C-88 & S.13 \\
\hline 7 & P. .99 & P.56 & C-88 & S-13 \\
\hline 8 & P.59 & P.56 & C.88 & S.7 \\
\hline 9 & P. .59 & P.56 & C.88 & S.14 \\
\hline 10 & P. 58 & P-55 & C.88 & S.6 \\
\hline 11 & P.58 & P.56 & C. 88 & S. 14 \\
\hline 12 & P.59 & P.55 & C-91 & S.8 \\
\hline 13 & P. 59 & P.55 & C.91 & S.11 \\
\hline
\end{tabular}


Table 4. Composition of synthetic 106-AN waste

\begin{tabular}{ll}
\hline Component & Molarity \\
\hline $\mathrm{NaAl}(\mathrm{OH})_{4}$ & 0.421 \\
$\mathrm{Na}_{2} \mathrm{SO}_{4}$ & 0.031 \\
$\mathrm{NaCl}$ & 0.15 \\
$\mathrm{NaF}$ & 0.0081 \\
$\mathrm{Ca}\left(\mathrm{NO}_{3}\right)_{2} 4 \mathrm{H}_{2} \mathrm{O}$ & 0.002 \\
$\mathrm{NaOH}(50 \%)$ & 0.675 \\
$\mathrm{NaNO}$ & 1.29 \\
$\mathrm{NaNO}_{2}$ & 0.758 \\
$\mathrm{Na}_{2} \mathrm{CO}_{3}$ & 0.382 \\
$\mathrm{HEDTA}$ & 0.019 \\
$\mathrm{Na}_{4} \mathrm{EDTA}_{2}$ & 0.0044 \\
$\mathrm{GlycOlic} \mathrm{acid}_{(70 \%)^{4}}$ & 0.042 \\
$\mathrm{Na}_{3} \mathrm{PO}_{4} 12 \mathrm{H}_{2} \mathrm{O}$ & 0.155 \\
$\mathrm{Na}_{3} \mathrm{C}_{6} \mathrm{H}_{3} \mathrm{O}_{2} 2 \mathrm{H}_{2} \mathrm{O}^{b}$ & 0.03 \\
\hline
\end{tabular}

"Hydroxyacetic acid.

bSodlum citrate. 


\subsubsection{Grout Preparation}

A predetermined volume of the waste was added to a Model N.50 Hobart Mixer, which was set to a low speed $(-140 \mathrm{rpm})$, and a predetermined weight of dry-solids material was added over a 10- to 15-s period and blended for a total of $30 \mathrm{~s}$. The mixer was then set to medium speed ( $285 \mathrm{rpm}$ ), and blending was continued for an additional $30 \mathrm{~s}$. The volume of grout prepared was sufficient for:

1. one sample for determination of rheological properties;

2. one sample for determination of drainable water;

3. one sample for determination of grout density; and

4. three samples for determination of compressive strength.

Grout preparation and subsequent data acquisition were repeated three times for each blend in the matrix.

\subsection{DETERMINATION OF RHEOLOOICAL PROPERTIES}

A total of $350 \mathrm{~mL}$ of grout (prepared as described in Sect. 4.2.3) was placed in a FANN viscometer. Shear stress data were obtained as a function of shear-rate at shear rate settings of $600,300,200,100,181,90,60$, and $30 \mathrm{rpm}$. The resulting data are represented by the power-law model as follows:

$$
S_{0}=k^{\prime}\left(S_{N^{n}}\right)^{n^{\prime}}
$$

where

$S_{1}=$ shear stress, $1 \mathrm{~b} / \mathrm{ft}^{2}$;

$k^{\prime}=$ fluid consistency index, $\mathrm{Ib}_{i} \mathrm{~s}^{\mathbf{n}} / \mathrm{ft}^{2}$;

$S,=$ shear rate, $s^{1,}$; and

$\eta^{\prime}=$ now behavior index $\left(0<\eta^{\prime}<1.0\right)$, dimensionless. 
From Eq. (1), the Reynolds number can be calculated by

$$
N_{M}=\frac{1.86 V^{\left(2-\eta^{\prime}\right)} p}{k^{\prime}\left(96 / d_{1}\right)^{n^{\prime}}},
$$

where

$$
\begin{aligned}
& N_{R_{*}}=\text { Reynolds number, dimensionless; } \\
& V \quad=\text { fluld velocity, } \mathrm{ft} / \mathrm{s} \text {; } \\
& d_{i} \quad=\text { inside diameter of pipe, in.; and } \\
& p \quad=\text { fluid density, lb/gal. }
\end{aligned}
$$

Critical velocity is determined from Eq. (2) assuming a Reynolds number of 2100 and a schedule 80 plpe of nominal 2-In. diameter. Grout density was determinert using an NL Baroid mud balance.

Additional nuid properties are calculated as follows:

$$
P_{1}=\frac{0.039 L_{p} V_{f}}{d_{1}}
$$

where

$P_{f} \quad$ - frictional pressure drop through a straight pipe, psi;

$L \quad=$ pipe length, $f_{t}$ and

$f \quad$ fanning friction factor (0.008), dimensionless;

and

$$
P_{n}=\frac{G A_{w}}{\left(1.44 \times 10^{d}\right) A_{p}}
$$

where

$$
\begin{aligned}
& P_{H} \quad=\text { pump head pressure necessary to overcome gel strength, psi; } \\
& G \quad=\text { gel strength, lb, } / 100 \mathrm{ft}^{2} \\
& A_{H} \quad=\text { pipe inside surface area, in. }{ }^{2} ; \text { and } \\
& A_{p} \quad=\text { inside pipe cross-sectional area, in. }
\end{aligned}
$$


For calculations presented in the report, the measured gel strength of the fresh grout is the maximum deflection taken from the FANN viscometer at $3 \mathrm{rpm}$ after the grout has remained static for $10 \mathrm{~min}$

\subsection{DETERMINATION OF SOLID.OROUT PROPERTIES}

\subsubsection{Unconflined Compresstve Strength}

Freshly prepared grout (Sect. 4.2.3) wai poured into three 2-in.-cube molds conforming to ASTM C-109.80 speciffcations and then placed on a Model VP5101 Syntron vibrating table at a setting of 6.5 for $20 \mathrm{~s}$. The samples were subsequently stored in a humidity cabinet maintained at $50^{\circ} \mathrm{C}$ and a relative humidity of $>95 \%$. Twenty-eight days after being placed in the molds, the cured grouts were removed and the unconfined compressive strength was determined using a Tinius Olsen Super L Universal Testing Machine in accordance with ASTM C 109-80.

\subsubsection{Drainable Water}

A to:al of $250 \mathrm{~mL}$ of freshly prepared grout (Sect. 4.2.3) was placed in a polymethylpentene graduated cylinder, which was sealed below the pour spout with an inverted No. 7 stopper. The cylinder was then stored in a cabinet maintained at $50^{\circ} \mathrm{C}$. Drainable water was observed at $2 \mathrm{~h}, 1 \mathrm{~d}, 7 \mathrm{~d}, 14 \mathrm{~d}, 21 \mathrm{~d}$, and $28 \mathrm{~d}$ after the grout had been placed in the cylinders.

\section{REFERENCE CONDITIONS}

In order to evaluate the effects of material source on grout properties with respect to establishing purchase specifications, two questions must be addressed: (1) Is there a statistical difference in grout propertles due to material source? and (2) Are these differences significant with respect to the established performance criteria? A discussion of these factors is included in Sects. 6 and 7 of this report: however, prior to a detailed statistical treatment, it is desirable to establish a performance bascline in order to provide guidance on subsequent data interpretation.

In order to provide this guidance, selected grout properties of the reference formulation were compiled from each matrix and then compared with established performance criteria, as shown in Tables 5 through 8 . In this context, the reference formulation refers to a dry-solids blend consisting of $40 \mathrm{wt} \%$ limestone, $28 \mathrm{wt} \%$ ASTM Class F fly ash, 28 wt \% BFS, and $4 \mathrm{wt} \%$ Type I.II-LA Portland cement, which is subsequently mixed with the waste at a ratio of $9 \mathrm{lb} / \mathrm{gal}$ (observation No. 9 in each matrix). 
Table 5. Data for critical velocity obtained from on reference formulation

\begin{tabular}{lll}
\hline $\begin{array}{l}\text { Run } \\
\text { No. }\end{array}$ & $\begin{array}{c}\text { Critical } \\
\text { velocity } \\
(\mathrm{gal} / \mathrm{min})\end{array}$ & $\begin{array}{c}95 \% \\
\text { Confidence } \\
\text { interval }\end{array}$ \\
\hline MX1-8 & $14.2 \pm 0.8$ & \pm 2.0 \\
MX2-3 & $13.9 \pm 0.6$ & \pm 1.5 \\
MX2R-3 & $14.1 \pm 0.5$ & \pm 1.2 \\
MX3-2 & $14.1 \pm 0.4$ & \pm 1.0 \\
MX4-1 & $14.7 \pm 0.2$ & \pm 0.5 \\
MX5-8 & $16.2 \pm 0.2$ & \pm 0.5 \\
MX6-7 & $16.1 \pm 0.1$ & \pm 0.2 \\
MX7-3 & $18.2 \pm 0.3$ & \pm 0.7 \\
MX8-4 & $16.6 \pm 0.5$ & \pm 1.2 \\
MX9-5 & $14.8 \pm 0.5$ & \pm 1.2 \\
MX10-1 & $15.2 \pm 0.8$ & \pm 2.0 \\
MX11-1 & $15.1 \pm 0.4$ & \pm 1.0 \\
MX12-4 & $15.7 \pm 0.2$ & \pm 0.5 \\
MX13-9 & $14.8 \pm 0.2$ & \pm 0.5 \\
\hline
\end{tabular}


Table 6. Data for 10-min gel strength obtained from reference formulation"

\begin{tabular}{lll}
\hline $\begin{array}{c}\text { Run } \\
\text { No. }\end{array}$ & $\begin{array}{c}10 \text {-min gel } \\
\text { strength } \\
\left(\mathrm{lb}_{f} / 100 \mathrm{ft}^{2}\right)\end{array}$ & $\begin{array}{c}95 \% \\
\text { Confidence } \\
\text { interval }\end{array}$ \\
\hline MX1-8 & $6.2 \pm 0.4$ & \pm 1.0 \\
MX2-3 & $10.8 \pm 2.5$ & \pm 6.2 \\
MX2R-3 & $3.5 \pm 0$ & $\pm 1.2^{\mathrm{c}}$ \\
MX3-2 & $13.0 \pm 1.0$ & \pm 2.5 \\
MX4-1 & $6.3 \pm 0.6$ & \pm 1.5 \\
MX5.8 & $6.5 \pm 0.5$ & \pm 1.2 \\
MX6-7 & $4.7 \pm 0.3$ & \pm 0.7 \\
MX7-3 & $5.5 \pm 0.5$ & \pm 1.2 \\
MX8-4 & $4.3 \pm 0.3$ & \pm 0.7 \\
MX9-5 & $4.2 \pm 0.3$ & \pm 0.7 \\
MX10-1 & $3.5 \pm 0.5$ & \pm 1.2 \\
MX11-1 & $4.2 \pm 0.3$ & \pm 0.7 \\
MX12-4 & $5.8 \pm 0.3$ & \pm 0.7 \\
MX13-9 & $4.7 \pm 0.3$ & \pm 0.7 \\
\hline
\end{tabular}

"Reference formulation corresponds to observation No. 9 in each matrix.

b Average value and one standard deviation obtained from three replicates.

'Interval calculated based on assumed standard deviation of 0.5 . 
Table 7. Data for 28-d drainable water obtained from reference formulation ${ }^{\mathrm{a}}$

\begin{tabular}{lll}
\hline $\begin{array}{c}\text { Run } \\
\text { No. }\end{array}$ & $\begin{array}{c}28-d \text { drainable } \\
\text { water }^{b} \\
(\text { vol \%) }\end{array}$ & $\begin{array}{c}95 \% \\
\text { Confidence } \\
\text { interval }\end{array}$ \\
\hline MX1-8 & $2.8 \pm 0.8$ & \pm 2.0 \\
MX2-3 & $15.3 \pm 1.2$ & \pm 3.0 \\
MX2R-3 & $8.4 \pm 0$ & $\pm 2.0^{c}$ \\
MX3-2 & $8.8 \pm 3.3$ & \pm 8.2 \\
MX4-1 & $7.9 \pm 3.0$ & \pm 7.5 \\
MX5-8 & $3.1 \pm 0.8$ & \pm 2.0 \\
MX6-7 & $4.7 \pm 0.8$ & \pm 2.0 \\
MX7-3 & $3.5 \pm 0.6$ & \pm 1.5 \\
MX8-4 & $5.3 \pm 0.5$ & \pm 1.2 \\
MX9-5 & $6.9 \pm 0.5$ & \pm 1.2 \\
MX10-1 & $7.7 \pm 0.8$ & \pm 2.0 \\
MX11-1 & $8.3 \pm 0.5$ & \pm 1.2 \\
MX12-4 & $4.0 \pm 0.4$ & \pm 1.0 \\
MX13-9 & $6.7 \pm 0.5$ & \pm 1.2 \\
\hline
\end{tabular}

"Reference formulation corresponds to observation No. 9 in each matrix.

${ }^{b}$ Average value and one standard deviation obtained from three replicates.

'Interval calculated based on assumed standard deviation of 0.8 . 
Table 8. Data for 28-d unconfined compressive strength obtained from reference formulation ${ }^{2}$

\begin{tabular}{lcl}
\hline $\begin{array}{c}\text { Run } \\
\text { No. }\end{array}$ & $\begin{array}{c}\text { 28-d unconfined } \\
\text { compressive } \\
\text { strength } \\
\text { (psi) }\end{array}$ & $\begin{array}{c}95 \% \\
\text { Confidence } \\
\text { interval }\end{array}$ \\
\hline MX1-8 & $489 \pm 49$ & \pm 38 \\
MX2-3 & $346 \pm 21$ & \pm 16 \\
MX2R-3 & $379 \pm 30$ & \pm 23 \\
MX3-2 & $306 \pm 33$ & \pm 25 \\
MX4-1 & $492 \pm 69$ & \pm 53 \\
MX5-8 & $380 \pm 23$ & \pm 18 \\
MX6-7 & $481 \pm 30$ & \pm 23 \\
MX7-3 & $383 \pm 30$ & \pm 23 \\
MX8-4 & $392 \pm 48$ & \pm 37 \\
MX9-5 & $367 \pm 32$ & \pm 25 \\
MX10-1 & $377 \pm 55$ & \pm 42 \\
MX11-1 & $510 \pm 75$ & \pm 58 \\
MX12-4 & $491 \pm 35$ & \pm 27 \\
MX13-9 & $436 \pm 41$ & \pm 32 \\
\hline
\end{tabular}


In Tables 5 through 7, average values for the selected properties were obtained from three replicate measurements on the reference formulation from each matrix, whiis average values reported in Table 8 were obtained from nine replicate measurements. The $95 \%$ confidence interval was calculated as follows:

$$
C= \pm t_{\alpha / 2}(\sigma / \sqrt{n}),
$$

where

$C=(1-a) \%$ confidence interval,

$t_{\mathrm{a} / 2}=$ value from $\mathrm{t}$ tables,

$\sigma \quad=$ standard deviation, and

$n=$ number of replicate data.

The confidence interval would be applied to the average value $(u)$ as follows: $u \pm C$. That is, for a value for the selected property of $u$, the data show an interval extending from $(u-C)$ to $(u+C)$ that includes the true value of $u$ with $95 \%$ probability. One would then be confident that the reference formulation meets the desired performance criteria with a high degree of confidence if the value of $u$ meets the performance criterion and the calculated confidence interval does not include the value for the performance criterion. It must be noted that the above discussion is limited to the reference formulation and is intended only to provide guidance to subsequent data interpretation; it is not intended to address the effects of variations in either the dry-solids-blend composition or the mix ratio.

As shown in Tables 5, 6, and 8, the confidence intervals for critical velocity, 10-min gel strength, and 28-d unconfined compressive strength do not include the performance criteria values of $60 \mathrm{gpm}, 100 \mathrm{lb}_{\mathrm{f}} / 100 \mathrm{ft}^{2}$, and $60 \mathrm{psi}$, respectively. This provides preliminary indications that vendor source will not affect these characteristics to the point where the grout will not be able to meet performance criteria with respect to these characteristics.

As shown in Table 7, the confidence interval for 28-d drainable water includes or exceeds the performance criterion value of $<5 \%$ for all of the data except MX1-8, which has a confidence interval of 0.8 to 4.8; however, the data from Matrixes 1, 2, and 3 are an anomaly, which will be discussed in Sect. 7. These data indicate that the ability of the reference formulation to meet the drainable water criterion of $\leqq 5$ vol \% is highly suspect; but, as the average values range from 8.4 to $3.1 \mathrm{vol} \%$, there is some indication that vendor source may affect the drainable water. Clearly, drainable water becomes a key variable to be addressed in the subsequent data analysis. 
6. STATISTICAL ANALYSIS TO DETERMINE EFFECTS OF MATERIAL SOURCE

Section 5 indicated that material source may have a significant effect on grout properties. In addition, 28-d drainable water was identified as a key variable that could be used to evaluate this potential effect. To determine whether the source of the components of the grout makes a difference in the grout's physical properties, one must compare the effects of a number of different "treatments" (i.e., different combinations of grout material sources) on grout properties.

\subsection{APPROACH UTILIZED IN STATISTICAL ANALYSIS}

Eleven different material source mixtures (or matrixes), denoted MX2R and MX4 through MX13, were compared to determine differences. The following physical properties were examined: compressive strength (CS); critical velocity (CV); frictional pressure drop (PD); pump-head pressure (PH); 10-min. gel strength (GS); density (DN); and drainable water after $2 \mathrm{~h}$ (D2), $1 \mathrm{~d}$ (D1), $7 \mathrm{~d}$ (D7), $14 \mathrm{~d}$ (D14), $21 \mathrm{~d}$ (D21), and $28 \mathrm{~d}$ (D28).

To perform this analysis, data from observation Nos. 9-A, -B, and -C from each matrix were utilized. In this context, observation No. 9 is a "treatment." It should be noted that observation No. 9 corresponds to the reference formulation as discussed in Sect. 5. The statistical technique used is called "analysis of variance," or ANOVAR (see Ref. 1, Chap. 6). In this approach, the statistical variance in the values of a physical property (e. g., D28) is calculated by two different procedures. One of these uses the differences within replicate runs of a treatment to estimate the variance, while the other uses differences between treatments (from the 11 matrixes) to estimate the same statistical parameter. An "F-test" is then performed on the ratio of these two estimates of the variance to determine whether viable differences exist. If the F-test indicates that the variance calculated by the "between-treatments" method is significantly larger than the "within-treatment" number, then it may be said that the different material sources do cause changes in the physical properties.

The F-test alone would not indicate the significance of differences between two specific sources but, rather, that differences exist between the 11 combinations that were tried. In order to address significant differences between specific sources, Tukey's paired comparison procedure (see Ref. 1., p. 204) may be used. This approach uses the studentized range parameter (or "Q-test") in order to set a lower limit by which values from two treatments or sources of material must vary in order to be meaningful. 
22

\subsection{COMPARISON OF REFERENCE FORMULATION TREATMENTS}

Table 9 contains a list of the F-test and Q-test results for the 11 treatments. Additional data are shown in Appendixes $\mathrm{J}$ and $\mathrm{K}$. The tabular entries indicate that significant differences were detected between the treatments or material sources in all physical property measurements. The $99 \%$ confidence level for the F-test is less than 4 ; thus, values greater than 4 indicate that differences exist. As shown in Table 9, it is quite evident that there are differences in all physical properties due to material source. For example, the F-test ratio for 28 -d drainable water (D28) is 20.75, which is well beyond the critical value of 4 .

For the properties that show vable differences, one can use the Q-test value to compare sources of materials in pairwise fashion. In the case of compressive strength (CS), the tabulated Q-test value is $118 \mathrm{psi}$ (see Appendix J). This means that the absolute value of the difference in CS between any two sources in question (1.e., treatments) must be greater than 118 psi in order to verify that a significant difference exists. For this test, one should use the values obtained by averaging the $A, B$, and $C$ runs for each treatment. With this technique, one may examinc the differences between any pair of material sources or treatments.

Although a statistical comparison has been performed on each of the physical characteristics, it is important to note that many of these comparisons do not yield additional information (i.e., many of the characteristics depend on one another). For example, within experimental error, a comparison of the $2-h$ drainable water (D2) values yields the same statistical information as the 28-d drainable water data. The same can be said for:

1. frictional pressure drop, which is dependent on critical velocity; and

2. pump-head pressure, which is dependent on 10-min gel strength.

However, a comparison of all determined physical characteristics is presented in this report to show that a comparison of these dependent characteristics will provide the same statistical information as a comparison of the nonrelated characteristics. Such documentation will provide the basis for reductions in the required measurements for future experiments on this issue.

An interesting point is emphasized when examining the frictional pressure drop data (PD) (see Appendix J). The precision of these data is insufficient to determine whether statistically significant differences exist. The data take on one of two values only, 5.5 or 5.6, and in only one case (MX13) is there a difference in the three replicates. This yields an extremely low and, probably, misleading estimate for the variance. Therefore, these data for frictional pressure drop should not be used to assess differences based on source. 
Table 9. F-test and Q-test values in reference formulation from 11 matrixes

\begin{tabular}{clll}
\hline Characteristic & $\begin{array}{l}\text { F-test } \\
\text { ratio }\end{array}$ & $\begin{array}{l}\text { Q-test } \\
\text { lower } \\
\text { limit }\end{array}$ & $\begin{array}{c}\text { Signilfcant } \\
\text { difference? }\end{array}$ \\
\hline CS & 6.0 & $118.4 \mathrm{psi}$ & Yes \\
CV & 29.1 & $1.4 \mathrm{gal} / \mathrm{min}^{2}$ & Yes \\
PD & 24.4 & $0.05 \mathrm{psi} / 100 \mathrm{ft}^{2}$ & Yes \\
PH & 23.1 & $0.43 \mathrm{psi}$ & Yes \\
GS & 27.4 & $1.7 \mathrm{lb} / 100 \mathrm{ft}^{2}$ & Yes \\
DN & 26.9 & $0.11 \mathrm{lb} / \mathrm{ft}^{3}$ & Yes \\
D2 & 21.3 & $6.3 \mathrm{~mL}$ & Yes \\
D1 & 20.3 & $7.7 \mathrm{~mL}$ & Yes \\
D7 & 23.8 & $7.7 \mathrm{~mL}$ & Yes \\
D14 & 24.5 & $7.8 \mathrm{~mL}$ & Yes \\
D21 & 24.0 & $7.8 \mathrm{~mL}$ & Yes \\
D28 & 20.8 & $8.5 \mathrm{~mL}$ & Yes \\
\hline
\end{tabular}




\subsection{APPLICATION TO FIEID OPERATION}

As discussed in Sect. 6.2, there is a statistically significant difference in grout characteristics based on material source. This conclusion was derived from comparisons of a single treatment from each source. It is recognized that, during routine operation of the GTF, variations in the reference formulation will occur. As discussed in Sect. 4, the formulations utillzed in each matrix represent a quarter factorial of the varlations that can be expected. As such, the "population" of formulations contained in each matrix is believed to be representative of the actual population of formulations expected during operation of the GTF. Thus, analysis of the overall response of each matrix should be representative of the expected range of possible operating conditions in the OTF. The analysis-of-variance approach discussed in Sects. 6.1 and 6.2 can be used to compare physical properties obtained over the operating range as a whole. That is to say, all of the data points for a particular grout characteristic from the various runs within a matrix can be combined (i.e., averaged) to obtain a characteristic value for the matrix of interest. These characteristic values, or averages, can then be analyzed as discussed in Sects. 6.1 and 6.2.

F.test and Q-test values obtained for these matrix average characteristics are listed in Table 10. Additional data are presented in Appendix $\mathrm{K}$. As seen in Table 10, there is a significant sta:istical difference between the grout sources, in each case, as indicated by the large values of the ratio of variances. This information serves to document that no anomalies are introduced by variations in the formulation composition, and that, in the future, the necessary statistical comparison can be performed on a more limited number of experiments, such as those described in Sects. 6.1 and 6.2 .

\section{APPLICATION TO PERFORMANCE CRITERIA}

As discussed in Sects. 5 and 6, grout characteristics show a statistically significant difference based on material source. This is not surprising because the various sources of materials translate to materials of differing particle size and chemical composition. Since the fluid grout can be characterized as a slurry, its properties should be dependent on the physical characteristics (e. g., particle size) of its individual components. Characteristics of the fina! product are determined after the cementitious reactions have occurred. Because the rate and, possibly, final product of these chemical reactions should be dependent on the particle size and chemical composition of the grout components, the product's characteristics may also be 
Table 10. F-test and Q-test values for matrix average characteristics

\begin{tabular}{cllc}
\hline Characteristic & $\begin{array}{l}\text { F.test } \\
\text { ratio }\end{array}$ & $\begin{array}{l}\text { Q-lest } \\
\text { lower } \\
\text { limit }\end{array}$ & $\begin{array}{c}\text { Significant } \\
\text { difference? }\end{array}$ \\
\hline CS & 14.2 & $82.8 \mathrm{psi}$ & Yes \\
CV & 18.1 & $1.0 \mathrm{gal} / \mathrm{min}$ & Yes \\
PD & 7.8 & $0.13 \mathrm{psi} / 100 \mathrm{ft}^{2}$ & Yes \\
PH & 10.4 & $0.5 \mathrm{psi}$ & Yes \\
OS & 10.7 & $1.35 \mathrm{lb} / 100 \mathrm{ft}^{2}$ & Yes \\
DN & 7.8 & $0.13 \mathrm{lb} / \mathrm{ft}^{3}$ & Yes \\
D2 & 31.0 & $3.9 \mathrm{~mL}$ & Yes \\
D1 & 26.9 & $4.7 \mathrm{~mL}$ & Yes \\
D7 & 24.0 & $4.8 \mathrm{~mL}$ & Yes \\
D14 & 23.8 & $4.9 \mathrm{~mL}$ & Yes \\
D21 & 22.4 & $4.9 \mathrm{~mL}$ & Yes \\
D28 & 21.9 & $5.0 \mathrm{~mL}$ & Yes \\
\hline
\end{tabular}

See Sect. 6.1 for definitions. 
dependent on the components. The key question then becomes, "Are the differences in grout characteristics due to material source significant with respect to performance requirements?" That is, "Do the grout characteristics vary sumctently to exceed performance constraints?"

\subsection{COMPARISON OF MATRIX CHARACTERISTIC VALUES}

As discussed prevlously, each matrix is comprised of nine runs that correspond to nine variations in the reference formulation. These variations are designed to be representative of the total population of variations expected during operation of the OTF. As such, the average of any particular grout characteristic from all runs within a matrix can reasonably be expected to approximate the average value of that characteristic obtained during operation of the OTF, using the source of materials in the matrix.

Characteristic values $(u)$ averaged ovet all applicable data within a matrix are shown in Tables 11, 12, 13, and 14 for critical velocity, 10-min gel strength, 28-d drainable water, and 28-d unconfined compressive strength, respectively. Also shown in the tables are the calculated confidence intervals $( \pm C)$. The confidence interval $(C)$ combined with the average value $(u)$ can be used as follows: The data show that the interval extending from $(u-C)$ to $(u+C)$ includes the true value of $u$ with $95 \%$ probability. Clearly, the values obtained for critical velocity, 10-min gel strength, and 28-d unconfined compressive strength are well within the performance criteria for all of the matrixes. Thus, for the materials evaluated in this study, material source has a negligible impact on these characteristics relative to the performance criteria.

Consistent with analysis presented in Sect. 5, 28-d drainable water continues to be a key variable for matrix average values. For both the averages obtained from the reference formulation (Sect. 5) and those for the entire matrix (presented here), the average values for 28-d drainable water were below the performance criterion of 5 vol $\%$ only for data from Matrixes $1,5,6,7$, and 12 . Applying the $95 \%$ confidence interval to the matrix-average values results in the following:

95\% Confidence interval for average 28-d drainable water

Matrix

1 (vol \%)

3.0104 .2

3.8 to 5.6

2.3 to 3.9

2.0 to 3.6

4.0 to 5.0 
Table 11. Characteristic values for critical velocity obiained by averaging applicable matrix data

\begin{tabular}{|c|c|c|}
\hline $\begin{array}{c}\text { Matrix } \\
\text { No. }\end{array}$ & $\begin{array}{l}\text { Crilical } \\
\text { velocity } \\
\text { (gal/min) }\end{array}$ & $\begin{array}{c}95 \% \\
\text { Confldence } \\
\text { interval }\end{array}$ \\
\hline $\mathbf{M X 1}$ & $14.6 \div 1.5$ & \pm 0.6 \\
\hline$M X_{2}$ & $13.6 \pm 1.2$ & \pm 0.5 \\
\hline$M \times 2 R$ & $13.6 \div 1.2$ & \pm 0.5 \\
\hline $\mathbf{M X 3}$ & $15.0 \neq 1.0$ & \pm 0.4 \\
\hline MX4 & $15.0 \div 1.2$ & \pm 0.5 \\
\hline MXs & $16.0=1.1$ & \pm 0.4 \\
\hline MX6 & $16.3 \div 1.5$ & 0.6 \\
\hline MX7 & $17.1=1.3$ & \pm 0.5 \\
\hline MX8 & $16.4 \neq 0.9$ & \pm 0.4 \\
\hline MX9 & $15.7 * 1.1$ & \pm 0.4 \\
\hline MX10 & $15.4 \div 1.0$ & \pm 0.4 \\
\hline$M \times 11$ & $15.0 \div 0.8$ & \pm 0.3 \\
\hline$M \times 12$ & $15.7 \neq 1.1$ & \pm 0.4 \\
\hline $\mathrm{MX} 13$ & $14.9 \div 1.0$ & \pm 0.4 \\
\hline
\end{tabular}

Average value and one standard deviation obtained from 27 data points. 
Table 12. Characteristic values for 10-min gel strength obtalned by averaging all applicable matrix data

\begin{tabular}{|c|c|c|}
\hline $\begin{array}{l}\text { Matrix } \\
\text { No. }\end{array}$ & $\begin{array}{l}\text { 10-min gel } \\
\text { strength" } \\
\left(16, / 100 n^{2}\right)\end{array}$ & $\begin{array}{c}95 \% \\
\text { Confidence } \\
\text { Interval }\end{array}$ \\
\hline$M \times 1$ & $6.4 \pm 1.2$ & 0.5 \\
\hline MX2 & $8.9 \div 3.9$ & 1.5 \\
\hline$M \times 2 R$ & $3.9 \div 0.7$ & \pm 0.3 \\
\hline $\mathbf{M} \mathbf{X}^{3}$ & $15.4 * 4.6$ & 21.8 \\
\hline $\mathrm{MX4}$ & $5.5 \div 1.1$ & \pm 0.4 \\
\hline MXs & $5.5=1.0$ & $\approx 0.4$ \\
\hline MX6 & $5.6 \neq 1.3$ & \pm 0.5 \\
\hline$M \times 7$ & $5.9 * 1.0$ & .0 .4 \\
\hline MX8 & $5.9 * 3.9$ & +1.5 \\
\hline MX9 & $4.6 \pm 0.9$ & \pm 0.4 \\
\hline MX10 & $3.9 \div 0.5$ & $\$ 0.2$ \\
\hline$M \times 11$ & $4.1 \div 1.0$ & .0 .4 \\
\hline$M \times 12$ & $7.0 \pm 1.7$ & \pm 0.7 \\
\hline$M \times 13$ & $5.0 \div 1.0$ & \pm 0.4 \\
\hline
\end{tabular}

'Average value and one standard deviation obtained from 27 data points. 
Table 13. Characteristic values tor 28-d drainable water obtained by averaging all applicable matrix data

\begin{tabular}{|c|c|c|}
\hline $\begin{array}{c}\text { Matrix } \\
\text { No. }\end{array}$ & $\begin{array}{c}\text { 28-d drainable } \\
\text { water } \\
\text { (vol \%) }\end{array}$ & $\begin{array}{c}95 \% \\
\text { Confidence } \\
\text { interval }\end{array}$ \\
\hline $\mathrm{MXI}$ & $3.6 \pm 1.6$ & \pm 0.6 \\
\hline$M \times 2$ & $13.2 \div 4.1$ & 21.6 \\
\hline$M \times 2 R$ & $9.1 \div 3.0$ & $\$ 1.2$ \\
\hline $\mathrm{M} \times 3$ & $9.5 * 3.6$ & $\neq 1.4$ \\
\hline $\mathrm{MX} 4$ & $5.8=3.1$ & \pm 1.2 \\
\hline MXs & $4.7 \div 2.4$ & \pm 0.9 \\
\hline MX6 & $3.1 \neq 1.9$ & $\$ 0.8$ \\
\hline$M \times 7$ & $2.8 \div 1.9$ & $* 0.8$ \\
\hline MX8 & $5.1 \div 2.1$ & \pm 0.8 \\
\hline MX9 & $7.0 \pm 1.9$ & 20.8 \\
\hline$M \times 10$ & $8.2 \div 2.2$ & \pm 0.9 \\
\hline$M \times 11$ & $8.1 * 1.6$ & \pm 0.6 \\
\hline$M \times 12$ & $4.5 * 1.2$ & .0 .5 \\
\hline$M \times 13$ & $8.0 \div 2.0$ & \pm 0.8 \\
\hline
\end{tabular}

'Average value and one standard deviation obtained from 27 data points. 
Table 14. Characteristic values for 28-d unconfined compressive strength obtained by averaging all applicable matrix data

\begin{tabular}{lcl}
\hline $\begin{array}{c}\text { Matrix } \\
\text { No. }\end{array}$ & $\begin{array}{c}\text { 28-d unconfined } \\
\text { compressive } \\
\text { strength } \\
(\text { psi) }\end{array}$ & $\begin{array}{c}95 \% \\
\text { Confidence } \\
\text { interval }\end{array}$ \\
\hline MX1 & $431 \pm 61$ & \pm 14 \\
MX2 & $371 \pm 37$ & \pm 8 \\
MX2R & $349 \pm 45$ & \pm 10 \\
MX3 & $372 \pm 56$ & \pm 12 \\
MX4 & $433 \neq 84$ & \pm 19 \\
MX5 & $425 \pm 80$ & \pm 18 \\
MX6 & $473 \pm 89$ & \pm 20 \\
MX7 & $377 \pm 80$ & \pm 18 \\
MX8 & $386 \pm 86$ & \pm 19 \\
MX9 & $388 \pm 59$ & \pm 13 \\
MX10 & $431 \pm 106$ & \pm 24 \\
MX11 & $579 \pm 183$ & \pm 41 \\
MX12 & $527 \pm 73$ & \pm 16 \\
MX13 & $429 \pm 71$ & \pm 16 \\
\hline
\end{tabular}


The confidence interval for Matrix 5 exceeds the performance criterion of $5 \%$. Thus, it can be stated with a high degree of confidence $(95 \%)$ that, on the average, formulation variations expected in the GTF with those materials used in Matrixes 1, 6, 7, and 12 will meet performance criteria with respect to critical velocity, 10-min gel strength, 28-d unconfined compressive strength, and 28-d drainable water.

\subsection{MATRIXES 1, 2, AND 3}

As mentioned previously, data obtained from Matrixes 1, 2, and 3 represent an anomaly with respect to the other natrixes. Grouts in Matrixes 1, 2, and 3 were prepared with synthetic 106-AN waste prepared from off-the-shelf chemicals. Beginning with Matrix 4, all grouts were prepared with a new batch of waste comprised of a fresh shipment of chemicals. The waste used in Matrixes 1, 2, and 3 contained a precipitate, while the new batch did not. Analysis of the precipitate indicated it to be predominantly $\mathrm{Al}(\mathrm{OH})_{3}$ in the form of Gibbsite and Bayerite. Thus, the data from Matrixes 1, 2, and 3 are not consistent with the other matrixes. In order to assess the effects of the precipitate on grout characteristics, Matrix 2 was repeated with a new batch of waste. The repeat matrix was labeled MX2R. A comparison between matrix average values obtained for Matrixes 2 and $2 R$ is as follows:

\begin{tabular}{lll}
\multicolumn{1}{c}{ Characteristic } & \multicolumn{2}{c}{$\begin{array}{c}\text { Matrix average at the } \\
\text { 95\% confldence level }\end{array}$} \\
\cline { 2 - 3 } & \multicolumn{1}{c}{ MX2 } & MX2R \\
\hline Critical velocity, gpm & $13.6 \pm 0.5$ & $13.6 \pm 0.5$ \\
10-min gel strength, $\mathrm{lh} / 100 \mathrm{ft}^{2}$ & $8.9 \pm 1.5$ & $3.9 \pm 0.3$ \\
28-d unconfined compressive strength, psi & $371 \pm 8$ & $349 \pm 10$ \\
28-d drainable water, vol \% & $13.2 \pm 1.6$ & $9.1 \pm 1.2$
\end{tabular}

This comparison indicates that the precipitate behaves as an ineri solid material. That is, the grouts prepared with the precipitate present are characterized by little change in critical velocity but an increase in gel strength, drainuole water, and unconfined compressive strength. Since the quantity of contained precipitate was not determined, it is not possible to determine the change in characteristics as a function of contained precipitate. As discussed previously, critical velocity, gel strength, and unconfined compressive strength met performance criteria. Consequently, if we assume that the grouts prepared with these materials, using waste containing no precipitate, will result in a reduction in average values for these characteristics, then the new 
grouts should be consistent with the performance requirements. However, assuming that the $31 \%$ reduction in drainable water is maintained for Matrixes 1 and 3, only Matrix 1 will meet the performance criterion with respect to drainable water.

\section{IMPACT ON PURCHASE SPECIFICATIONS}

The dry-solids-blend components used in this project included (1) ASTM Class T limestone at two particle-size distributions, (2) ASTM Class F fly ash at two CaO contents, (3) Type I-II-LA Portland cement from two distinct sources, and (4) BFS from numerous sources with Blaine fineness ranging from 390 to $627 \mathrm{~m}^{2} / \mathrm{kg}$. Although grade classification of the BFS is to be performed next fiscal year, the Blaine fineness values are believed to correspond to grades of 100 and 120. These materials encompassed expected variations permitted under the basic applicable ASTM standards.

\subsection{RHEOLOGICAL PROPERTIES}

The following theological properties were determined in this study: critical velocity, frictional pressure drop, 10-min gel strength, pump-head pressure, and density. Average values determined on both the reference formulation and a matrix designed to represent the population of formulation variations expected in the GTF indicated that, with a high degree of confidence, all combinations of material sources tested easily met performance requirements with respect to these characteristics. Thus, with regard to these characteristics, the basic ASTM standards appear to be sufficient in order to properly characterize, or give specifications for, the dry-solidsblend materials. That is, in order to meet the desired rheological property performance criteria, the following purchase specifications appear to be sufficient:

1. Limestone: ASTM C $602-69$ Class $T$. It is believed that other class designations would also meet the rheological criteria; however, since only Class $T$ has been evaluated, purchase specifications should remain consistent with the existing support documentation.

2. Fly ash: ASTM C 618-85 Class F - The data presented in this report evaluated Class F fly ash at $\mathrm{CaO}$ contents of 6 and 12\%. This provides reasonable assurance that a variable $\mathrm{CaO}$ content (allowed by $\mathrm{C} 618-85$ specifications) has no deleterious impact on rheological properties. In theory, the $\mathrm{CaO}$ content of Class $\mathrm{F}$ fly ash could range as high as $30 \%$; however, in practice, the value is more typically less than $15 \%$. Since vendors have no direct 
means of controlling $\mathrm{CaO}$ content, it is not desirable to make it a purchase specification; however, it is recommended that reporting of the $\mathrm{CaO}$ content be a requirement. It is expected that the majority of potential vendors will have fly ash with $\mathrm{CaO}$ contents below $15 \%$; any values significantly above $15 \%$ should be viewed as cause for concern.

3. Cement: ASTM C150-84 Type I-II-LA Portland cement - As discussed previously, cement, as classified by $C 150-84$, has a long historical "track record"; thus, these standard specifications are sufficient.

4. BFS: ASTM C $989-88$ Grade 100 and 120 - The grade specifications must be considered preliminary at this point. BFSs evaluated included Blaine fineness values of 390 to $627 \mathrm{~m}^{2} / \mathrm{kg}$, which are believed to be consistent with grades 100 and 120 specifications; however, characterization, with respect to grade, is scheduled for fiscal year 1991.

\subsection{PRODUCT PROPERTIES}

Two product properties, 28-d unconfined compressive strength and drainable water, were determined for each study. The average values determined on both the reference formulation and a matrix designed to represent the population of formulation variations expected in the GTF indicated that, with a high degree of confidence, all combinations of material source tested easily met performance requirements with respect to 28-d unconfined compressive strength. Thus, with regard to this characteristic, the basic ASTM standards (Sect. 8.1) appear to be sufficient in order to properly characterize, or give specification for, the dry-solids-blen materials. However, the same conclusion did not hold true for 28 -d drainable water. Average values for the reference formulation and the matrix routinely exceeded the performance criterion of 5 vol \% drainable water. Only data obtained from Matrixes $1,6,7$, and 12 met this criterion with any degree of confidence. Matrixes 1 and 12 contained limestone flour and BFS S-8. Matrixes 6 and 7 contained limestone flour and BFS S-13. Matrixes 1 and 12 also varied the source of cement, while Matrixes 6 and 7 varied the source of fly ash; thus, it can be inferred that the sources of cement and fly ash do not play a major role in controlling drainable water when used with limestone flour and either BFS S-8 or S-13.

Assuming that the control of drainable water is due, in large part, to the sorption or wetting of the limestone, then the use of limestone flour, with its smaller particle size, and, hence, larger surface area as compared with the ground limestone, would prove beneficial in controlling the drainable water. A comparison of average $28-\mathrm{d}$ drainable water data from 
Matrixes 4 and 10 supports this premise. Components in Matrixes 4 and 10 are identical except that Matrix 4 used limestone flour, while Matrix 10 used ground limestone. The average 28-d drainable water for Matrix 4 was 5.8 vol \%, while that for Matrix 10 was $8.2 \mathrm{vol} \%$.

This sensitivity of drainable water, with respect to the surface area of limestone within the ASTM Class $T$ designation, has potentially serious implication on both plant operation and material purchase specifications. Requiring a finer grind of limestone beyond that consistent with ASTM C 602-69 will certainly increase its cost. In addition, without significant additional development effort, neither the acr ptable range in particle-size distribution to be used as a purchase specification nor a correlation between particle-size distribution and drainable water can be established. Such a developmental effort is not consistent with budget and schedule constraints. Thus, it can be assumed that, because of differences in particle-size distribution, the plant will experience variations in drainable water from batch to batch of limestone flour. At present, the size of these variations must be considered unknown. It can only be assumed that if the purchase specifications for limestone flour are made consistent with the material used in this study, the drainable water criterion should be met most of the time.

Significantly, the limestone flour controlled the 28-d drainable water content to within desired limits only in combination with BFS S-8 and S-13. The cause of this synergistic effect is unknown at present. The Blaine fineness values for S-8 and S-13, 390 and $567 \mathrm{~m}^{2} / \mathrm{kg}$, respectively, essentially bracket the values for the other BFSs tested. Thus, the synergistic effect does not appear to be due to the particle size or grade of the BFS. Some other, as yet to be identified, characteristic of the BFS is apparently the cause. Another possibility is that a unique product microstructure created a situation whereby only those samples that contained the limestone flour, in combination with BFS S-8 and S-13, exhibited satisfactory 28-d drainable water values. This possibility might have been verified by the use of comparative micrographic evidence. As such, it is recommended that the acquisition of such micrographic informa'ion become a routine part of studies such as this.

Based on available data, only limestone flour in combination with BFSs S-8 and S-13 achieved the desired drainable water criterion. Specifying the purchase of these materials from the designated sources may impact both their cost and their long-term availability. In addition, lack of an understanding of the specific desirable characteristic, and, hence, the ability to control it through the use of purchase specifications, means that the variability of the material from these sources may well impact drainable water.

It must be recognized that drainable water data were obtained at $50^{\circ} \mathrm{C}$ in this study, while grouts to be produced within the GTF are expected to experience higher temperatures. The data presented in this report were obtained at $50^{\circ} \mathrm{C}$ to allow measurements to be taken at 
various time intervals. At temperatures above $50^{\circ} \mathrm{C}$, losses due to evaporation become significant, requiring specialty containers to seal the samples. These containers do not allow visual observation of drainable water without opening the containers and, hence, rendering the sample unusable for further observation. The schedule and the cost constraints for this project were not compatible with the large number of such containers needed. Nonetheless, the data are thought to be sufficient to identify the acceptability of the grout product with respect to the drainable water criterion. On the other hand, it should be pointed out that a companion study being performed at Pacific Northwest Laboratories (PNL) indicates that drainable water may decrease with increasing cure temperatures. Although unlikely that the decrease would be sufficient to meet this criterion, it is recommended that the data base associated with the PNL study be assessed to determine whether the current documentation is sufficient to allow the extrapolation of data presented here to expected cure temperatures.

Of the grout characteristics studied in this report, drainable water has been identified as the key variable relative to purchase specifications. Relaxation of this criterion would greatly increase the available sources of materials and, hence, allow a more competitive bid. In light of this situation, it is recommended that consideration be given to (1) formulation enhancement to improve its retention of water and/or (2) relaxation of the drainable water criterion.

\section{SUMMARY AND RECOMMENDATIONS}

This report documents progress made to date on efforts in support of the WHC Grout Technology Program to assess the effects of the source of the dry-solids-blend materials on grout characteristics of the 106-AN formulation. This formulation consists of a dry-solids blend containing $\mathbf{4 0}$ wt \% limestone, $28 \mathrm{wt} \%$ granulated blast furnace slag, $28 \mathrm{wt} \%$ ASTM Class F fly ash, and 4 wt \% Type I-II-LA Portland cement. The blend is mixed with 106-AN waste at a ratio of $9 \mathrm{lb}$ of dry-solids blend per gallon of waste.

Numerous sources of dry-solids-blend materials were obtained. Grouts were prepared with various combinations of these materials and synthetic 106-AN waste. The composition of the grout formula was varied in such a manner as to produce a matrix of grouts for each component combination designed to represent the population of variations expected during operation of the GTF. The following characteristics were determined for each grout formulation: critical velocity, frictional pressure drop, 10-min gel strength, fluid density, 28-d unconfined compressive strength, and 28-d drainable water. Based on a comparison of the average characteristics of the reference formulation and the matrix population, it has been 
determined that there is a statistically significant difference in all measured grout characteristics because of the source of the dry-solids-blend components.

Significantly, all grouts evaluated in this report met OTF performance requirements with respect to critical velocity, frictional pressure drop, 10-min gel strength, and 28-d unconfined compressive strength. Thus, although the source of material affects the grout properties, the impact is not significant relative to the performance that is desired or expected, based on these properties. However, the same conclusion cannot be drawn with respect to 28-d drainable water. Average values for the reference formulation and the matrix routinely exceeded the performance criterion of 5 vol \% drainable water. Only data obtained from Matrixes 1, 6, 7, and 12 met this criterion with any degree of confidence. Matrixes 1 and 12 contained limestone flour and BFS S-8, while Matrixes 6 and 7 contained limestone flour and BFS S-13. Matrixes 1 and 12 also varied the source of cement, while Matrixes 6 and 7 varied the source of fly ash. Thus, it can be inferred that the sources of cement and fly ash do not play a major role in controlling drainable water when used with limestone flour and either BFS S-8 or S-13.

Assuming that control of the drainable water is due, in large part, to the sorption or wetting of the limestone, then, the use of limestone flour with its smaller particle size and, hence, larger surface area, as compared with the ground limestone, should prove beneficial in controlling drainable water. A comparison of average 28-d drainable water data from Matrixes 4 and 10 supports thic premise. Components in Matrixes 4 and 10 are identical except that Matrix 4 used limestone flour, while Matrix 10 used ground limestone. The average 28-d drainable water for Matrix 4 was $5.8 \mathrm{vol} \%$, while that for Matrix 10 was 8.2 vol \%.

This sensitivity of drainable water with respect to the surface area of limestone within the ASTM Class $T$ designation has potentially serious implications on both plant operation and material purchase specifications. Requiring a finer grind of limestone beyond that consistent with ASTM C 602.69 will certainly increase its cost. In addition, without significant additional developmental effort, neither the acceptable range in particle-size distribution to be used as a purchase specification nor a correlation between particle-size distribution and drainable water can be established. Such an effort is not consistent with budget and schedule constraints; thus, it can be assumed that, because of differences in particle-size distribution, the plant will experience variations in drainable water from batch to batch of limestone flour. At present, the size of these variations must be considered unknown. It can only be assumed that if the purchase specifications for limestone flour are made consistent with the material used in this study, then drainable water criterion should be met the majority of the time.

Significantly, the limestone flour controlled 28-d drainable water to within the desired limits only in combination with BFS S.8 and S-13. The cause of this synergistic effect is 
unknown at present. The Blaine fineness values for S-8 and S-13, 390 and $567 \mathrm{~m}^{2} / \mathrm{kg}$, respectively, essentially bracket the values for the other BFSs tested. Thus, the synergistic effect does not appear to be due to the particle size or grade of the BFS. Some other, as yet to be identified, characteristic of the BFS appears to be the cause. Clearly, efforts to be conducted next fiscal year should focus on a detailed characterization of the BFSs and their impact on drainable water.

The statistical treatment of the data in this report clearly indicates that the comparison of reference formulation characteristics provides information similar to that obtained by comparing the average matrix values. Thus, during the studies to be conducted next fiscal year, the number of experiments may be greatly reduced as compared with those summarized in this report. (This reduction is required in order to meet existing budget and schedule constraints.) It should also be noted that the data base contained in this report, combined with material characterization data (to be obtained next fiscal year), should provide guidance as to additional experiment requirements and insight to additional purchase specifications.

\section{ACKNOWLEDGMENT}

The authors wish to thank T. L. Welsh and C. M. Sager, Westinghouse Hanford Company, for their assistance in developing the blend-composition matrix. They also wish to thank the following individuals for their technical review of this report: M. T. Harris and J. L. Shoemaker, Martin Marietta Energy Systems, Inc.; and E. F. Riebling, Westinghouse Hanford Company.

\section{REFERENCES}

1. G. E. P. Box, W. G. Hunter, and J. S. Hunter, Statistics For Experimenters, John Wlley \& Sons, Inc., New York, 1978. 
APPENDIXES 
Appendix A: Characterization of Dry-Solids-Blend Materials 


\section{$\mathrm{CaCO}_{3}$}

Source: Ash Grove Cement West, Inc.

P. O. Box 83007

St. Johns Station

Portland, Oregon 97283-0007

Label: P.58 (Ground) and P.59 (Flour)

\begin{tabular}{lcc}
\hline Mesh & $\begin{array}{c}\text { Ground limestone' } \\
(\%)\end{array}$ & $\begin{array}{c}\text { Limestone flour } \\
(\%)\end{array}$ \\
\hline 10 & 99 & 100 \\
20 & 97 & 99 \\
40 & 90 & 98 \\
60 & 80 & 94 \\
100 & 70 & 90 \\
\hline
\end{tabular}

Label P.58.

'Label P.59. 
Coment, Type I-11-LA

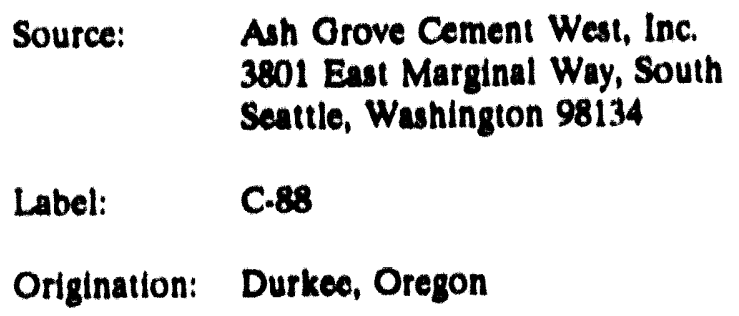

CHIEMICAL COMPOSITION \%

$\begin{array}{lr}\mathrm{SiO}_{2} & 22.38 \\ \mathrm{Al}_{2} \mathrm{O}_{1} & 3.79 \\ \mathrm{Fe}_{2} \mathrm{O}, & 4.25 \\ \mathrm{CaO} & 64.43 \\ \mathrm{MgO} & 1.61 \\ \mathrm{SO}_{3} & 2.04 \\ \text { Loss on ignition } & 1.24 \\ \text { Insoluble residue } & 0.23 \\ \text { Total alkalles }\left(\mathrm{as} \mathrm{Na}_{2} \mathrm{O}\right) & 0.43 \\ \mathrm{CS} & 54.8 \\ \mathrm{C} S & 22.8 \\ \mathrm{C} \mathrm{A} & 2.9 \\ \mathrm{C} A \mathrm{AF} & 12.9\end{array}$

\section{PHYSICAL TIESTS}

$\begin{array}{ll}\text { Blaine fineness } & 360 \mathrm{~m}^{2} / \mathrm{kg} \\ \text { Normal consistency } & 24.6 \% \\ \text { Setting time - Vicat } & \\ \text { Initial } & 150 \mathrm{~min} \\ \text { Final } & 235 \mathrm{~min} \\ \text { False set } & 86.8 \% \\ \text { Autoclave expansion } & +0.039 \% \\ \text { Air entrainment } & 7.0 \% \\ \text { Compressive strength, psi } & \\ 1 \mathrm{~d} & \\ 3 \mathrm{~d} & 1345 \\ 7 \mathrm{~d} & 2860 \\ & 3985\end{array}$


Cament, Type II

Source:

Lafarge Corporation

N. 209 Havana Street

Spokane, Washington 99213.3189

Label: $\quad$ C.91

Origination: Exhaw, Aberta, Canada

\section{CHEMICAL COMPOSITION. $\%$}

$\mathrm{SIO}_{2}$

$A 1, O$,

$\mathrm{Fe}_{2} \mathrm{O}$,

$\mathrm{CaO}$

$\mathrm{MgO}$

SO,

Loss on Ienition

Insoluble residue

Total alkalies (as $\mathrm{Na}, \mathrm{O}$ )

çs

C.S

C,A

CAAF
21.14

3.59

5.18

61.53

4.32

2.42

0.94

0.20

0.58

51.13

22.03

0.89

15.77

\section{PHYSICAL TESTS, DA}

Blaine fineness

Setting lime - Vicat Initial

Final

Autoclave expansion

Air entralnment

$386 \mathrm{~m}^{2} / \mathrm{kg}$

$115 \mathrm{~min}$

$195 \mathrm{~min}$

$0.10 \%$

$7.4 \%$

Compressive strength, psi

$$
3 \text { d }
$$

$7 d$

3065

3875 
Fy Aun, ASTM Cons F

$\begin{array}{ll}\text { Source: } & \begin{array}{l}\text { Pozzolanic Northwest } \\ 7525 \text { SE 24th Street } \\ \text { Sulte } 630 \\ \text { Mercer Island, Washington } 98040\end{array} \\ & \begin{array}{l}\text { P.55 } \\ \text { Label: }\end{array} \\ \text { Origination: Centralla Plant, Washington } \\ \end{array}$

Sillocon dioxide

Aluminum oxide

23.32

Iron oxdde

6.46

Total

75.71

Sulfur irloxide

0.59

Calcium oxdde

11.67

Moisture content

0.05

Loss on Ignition

0.06 
Fly Ash, ASTM Clans F

Source: Pozzolanic International

7525 SE 24th Street

Sulte 630

Mercer Island, Washington 98040

Label: P.56

Origination: Jim Bridger Plant

\section{CHEMICAL COMPOSITION $\%$}

Sillicon dioxide

Aluminum oxide

Iron oxide

Total

Sulfur trioxdde

Calcium oxide

Moisture content

Loss on Ignition
62.73

18.16

5.08
85.97

0.44

6.08

0.03

0.26 


\section{Oranulated Binat Furnace Slag}

Source: The Standard Slag Company

1200 Stambaugh Bullding

P. O. Box 1378

Youngstown, Ohio 44501

Label: $\quad$ S.6 (5000 Blaine) and S.7 (6000 Blaine)

\section{General Properties}

\section{CHEMICAL.PROPERTIES}

$\mathrm{CaO}$

$\mathrm{MgO}$

$\mathrm{SiO}_{2}$

$\mathrm{Al}_{2} \mathrm{O}$

$\mathrm{FeO}$

$\mathrm{MnO}$

$S$

$\mathrm{Na}_{2} \mathrm{O}$ equivalent

Base/acid ratio

\section{PHYSICAL PROPERTIES}

Color

Specific gravity

Blaine fineness, $\mathrm{cm}^{2} / \mathrm{g}$

325 mesh, \% retained
BANGE \%

$36 \cdot 41$

$10 \cdot 13$

$34 \cdot 36$

$8 \cdot 11$

$0.4-0.8$

$0.4 \cdot 0.8$

$1.5 \cdot 2.0$

$<1.0$

$1.0 \cdot 1.2$

Off-white

$2.90 \cdot 2.95$

$40000 \cdot 55(00)$

$2 \cdot 5$ 
Source: Ash Grove Cement West, Inc.

3801 East Marginal Way, South

Seattle, Washington 98134

Label: $\quad$ S-8

Origination: Kawasaki Steel, Japan; ground in Seattle Plant

\section{CHEMICAL}

Sulfur (as sulfide)

Max. $2.5 \%$

$0.72 \%$

Sulfate (as $\left.\mathrm{SO}_{3}\right)$

$\operatorname{Max} .4 .0 \% \quad 1.91 \%$

\section{PHYSICAL}

Fineness:

Air permeability, Blaine

$599 \mathrm{~m}^{2} / \mathrm{kg}$

Retained on No. 325 Sieve, max. $20 \%$ 
50

\section{Granulated Blast Furnace Slag}

Source: Blue Circle Atlantic, Inc.

P. O. Box 3

Ravena, New York 12143

Label: $\quad$ S-9 (Grade 120) and S-10 (Grade 100)

Origination: Sparrows Point Plant, Maryland

\section{CHEMICAL ANALYSES, \%}

$\begin{array}{lrc}\mathrm{SiO}_{2} & 35.33 & 35.51 \\ \mathrm{Al}_{2} \mathrm{O}_{3} & 10.26 & 10.36 \\ \mathrm{Fe} 2 \mathrm{O} 3 & 1.83 & 1.74 \\ \mathrm{CaO} & 38.29 & 38.45 \\ \mathrm{MgO} & 12.42 & 12.72 \\ \mathrm{~S} & 1.00 & 1.02 \\ \mathrm{Na}_{2} \mathrm{O} & 0.20 & 0.20 \\ \mathrm{~K}_{2} \mathrm{O} & 0.38 & 0.38 \\ \text { Gain on ignition } & 0.60 & 1.00\end{array}$

\section{FINENESS}

325 Residue, \%

Blaine, $\mathrm{cm}^{2} / \mathrm{g}$
3.0

5410
5.7

4170 
Source: $\quad$ C. T. Takahashi \& Co., Inc.

Bay Vista Building, Suite 230

2815 Second Avenue

Seattle, Washington 98121

Label: $\quad$ S-11 (3720 Blaine)

Origination: Nippin Steel Chemical Co., Ltd., Japan

CHEMICAL COMPOSITION, \%

Silicon dioxide $\left(\mathrm{SiO}_{2}\right) \quad 33.0$

Aluminum oxide $\left(\mathrm{Al}_{2} \mathrm{O}_{3}\right) \quad 14.6$

Ferric oxide $\left(\mathrm{Fe}_{2} \mathrm{O}_{3}\right) \quad 0.6$

Calcium oxide $(\mathrm{CaO}) \quad 41.1$

Magnesium oxide $(\mathrm{MgO}) \quad 6.7$

Sulfur (S) $\quad \underline{0.8}$

$\begin{array}{ll}\text { Total } & 96.8\end{array}$

\section{PHYSICAL PROPERTIES}

Specific gravity

Fineness, $\mathrm{cm}^{2} / \mathrm{g}$ 


\section{Granulated Blast Furnace Slag}

Source: $\quad$ C. T. Takahashi \& Co., Inc.

Bay Vista Building, Suite 230

2815 Second Avenue

Seattle, Washington 98121

Label: $\quad$ S-12 (5060 Blaine)

Origination: Nippin Steel Chemical Co., Ltd., Japan

CHEMICAL COMPOSITION, \%

Silicon dioxde $\left(\mathrm{SiO}_{2}\right) \quad 34.6$

Aluminum oxide $\left(\mathrm{Ai}_{2} \mathrm{O}_{3}\right)$

$\begin{array}{ll}\text { Ferric oxide }\left(\mathrm{Fe}_{2} \mathrm{O}_{3}\right) & 0.2\end{array}$

Calcium oxide $(\mathrm{CaO}) \quad 41.2$

$\begin{array}{ll}\text { Magnesium oxide }(\mathrm{MgO}) & 6.8\end{array}$

Sulfur (S) $\quad \underline{0.7}$

$\begin{array}{lr}\text { Total } & 97.8\end{array}$

\section{PHYSICAL PROPERTIES}

Specific gravity $\quad 2.90$

Fineness, $\mathrm{cm}^{2} / \mathrm{g} \quad 5060$ 
Source: Standard Slag Cement 360 Jones Road

Fruitland, Ontario LOR 1LO

Label: $\quad$ S.13 (3910 Blaine)

Origination: Hamilton, Ontario

Typical Analysis. \%

Typical Range in Analysis, \%

$\begin{array}{llllll}\text { Calcium } & (\mathrm{CaO}) & 36.66 & \text { Calcium } & (\mathrm{CaO}) & 33-44 \\ \text { Alumina } & \left(\mathrm{Al}_{2} \mathrm{O}_{3}\right) & 10.49 & \text { Alumina } & \left(\mathrm{Al}_{2} \mathrm{O}_{3}\right) & 9.12 \\ \text { Silica } & \left.\mathrm{SiO}_{2}\right) & 35.37 & \text { Silica } & \left(\mathrm{SiO}_{2}\right) & 33-38 \\ \text { Magnesia } & (\mathrm{MgO}) & 13.4 & \text { Magnesia } & (\mathrm{MgO}) & 12-16.5 \\ \text { Ferrous oxide } & \left(\mathrm{Fe}_{2} \mathrm{O}_{3}\right) & 0.96 & \text { Ferrous oxide } & \left(\mathrm{Fe}_{2} \mathrm{O}_{3}\right) & 0.5-1.9 \\ \text { Manganese } & (\mathrm{MnO}) & 0.64 & \text { Manganese } & (\mathrm{MnO}) & 0.3-1.0 \\ \begin{array}{l}\text { Sulphur } \\ \text { (Total) }\end{array} & (\mathrm{S}) & 1.50 & \begin{array}{l}\text { Sulfur } \\ \text { (Total) }\end{array} & (\mathrm{S}) & 1.0-2.3\end{array}$

Trace elements and loss on ignition 


\section{Granulated Blast Furnace Slag}

Source: $\quad$ Standard Slag Cement

360 Jones Road

Fruitland, Ontario LOR 1LO

Label: $\quad$ S-14

Origination: Hamilton, Ontario. (Ground in laboratory of the Standard Slag Company.)

Typical Analysis, \%

Typical Range in Analysis, \%

\begin{tabular}{|c|c|c|c|c|c|}
\hline Calcium & $(\mathrm{CaO})$ & 36.66 & Calcium & $(\mathrm{CaO})$ & 33.44 \\
\hline Alumina & $\left(\mathrm{Al}_{2} \mathrm{O}_{3}\right)$ & 10.49 & Alumina & $\left(\mathrm{Al}_{2} \mathrm{O}_{3}\right)$ & $9-12$ \\
\hline Silica & $\left.\mathrm{SiO}_{2}\right)$ & 35.37 & Silica & $\left(\mathrm{SiO}_{2}\right)$ & 33.38 \\
\hline Magnesia & $(\mathrm{MgO})$ & 13.4 & Magnesia & $(\mathrm{MgO})$ & $12-16.5$ \\
\hline Ferrous oxide & $\left(\mathrm{Fe}_{2} \mathrm{O}_{3}\right)$ & 0.96 & Ferrous oxide & $\left(\mathrm{Fe}_{2} \mathrm{O}_{3}\right)$ & $0.5-1.9$ \\
\hline Manganese & $(\mathrm{MnO})$ & 0.64 & Manganese & $(\mathrm{MnO})$ & $0.3-1.0$ \\
\hline $\begin{array}{l}\text { Sulphur } \\
\text { (Total) }\end{array}$ & (S) & 1.50 & $\begin{array}{l}\text { Sulfur } \\
\text { (Total) }\end{array}$ & (S) & $1.0-2.3$ \\
\hline $\begin{array}{l}\text { Trace elements } \\
\text { and loss on } \\
\text { ignition }\end{array}$ & \pm & 1.13 & & & \\
\hline
\end{tabular}


Appendix B: ADDITIONAL MATERIAL CHARACTERIZATION DATA 
Table B.1. Density of matrix materials"

\begin{tabular}{|c|c|c|c|}
\hline \multirow{3}{*}{$\begin{array}{l}\text { Material } \\
\text { C-88 }\end{array}$} & \multicolumn{3}{|c|}{ Density $\left(\mathrm{g} / \mathrm{cm}^{3}\right)$} \\
\hline & \multicolumn{2}{|c|}{ Replicate measurements } & \multirow{2}{*}{$\begin{array}{c}\text { Average } \\
3.18\end{array}$} \\
\hline & 3.176 & 3.184 & \\
\hline $\begin{array}{l}\text { P.55 } \\
\text { P. } 56\end{array}$ & $\begin{array}{l}2.183 \\
2.336\end{array}$ & $\begin{array}{l}2.178 \\
2.341\end{array}$ & $\begin{array}{l}2.18 \\
2.34\end{array}$ \\
\hline $\begin{array}{l}\text { S.6 } \\
\text { S-7 } \\
\text { S-8 } \\
\text { S-9 } \\
\text { S-10 } \\
\text { S-11 } \\
\text { S-12 } \\
\text { S-13 } \\
\text { S-14 }\end{array}$ & $\begin{array}{l}2.896 \\
2.896 \\
2.869 \\
2.909 \\
2.903 \\
2.896 \\
2.896\end{array}$ & $\begin{array}{l}2.889 \\
2.889 \\
2.896 \\
2.909 \\
2.909 \\
2.909 \\
2.896\end{array}$ & $\begin{array}{l}2.89 \\
2.89 \\
2.88 \\
2.91 \\
2.91 \\
2.90 \\
2.90\end{array}$ \\
\hline
\end{tabular}

'Determined by ASTM C188-84. 
Table B.2. Hydraulic activity of S-6 by reaction with alkali

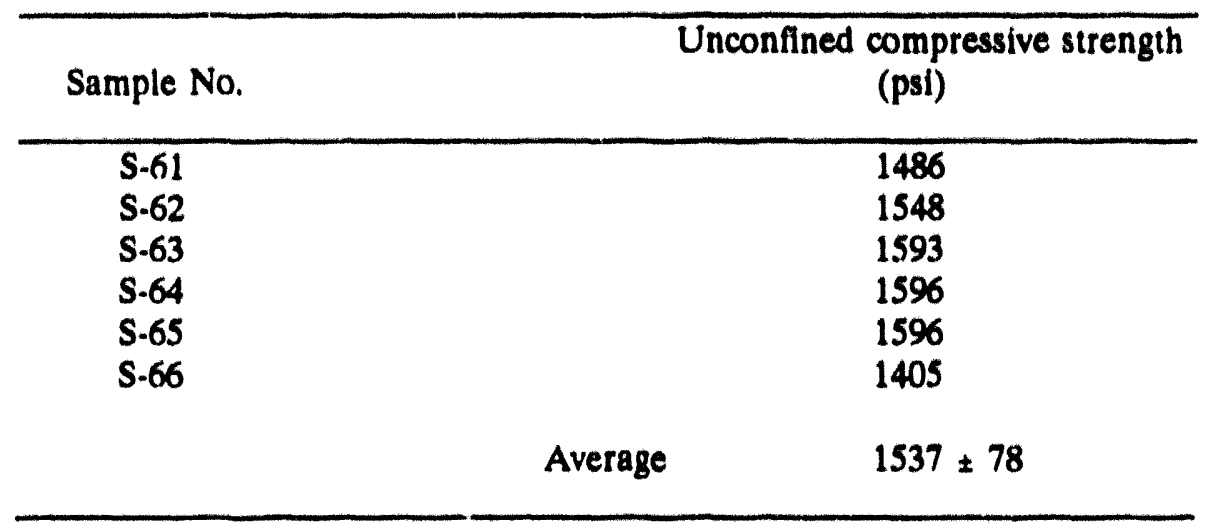

Table B.3. Hydraulic activity of S-7 by reaction with alkali

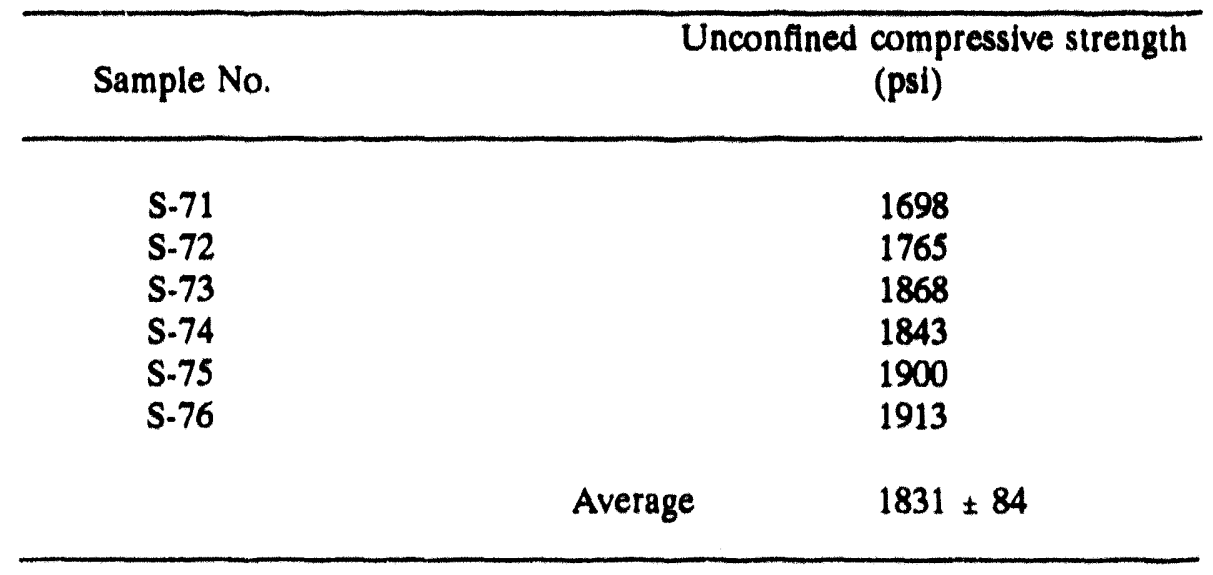


Table B.4. Hydraulic activity of $S .8$ by reaction with alkali

\begin{tabular}{|c|c|}
\hline Sample No. & $\begin{array}{l}\text { Unconfined compressive strength } \\
\text { (psi) }\end{array}$ \\
\hline \multirow[t]{2}{*}{$\begin{array}{l}\text { S.82 } \\
\text { S.83 } \\
\text { S-84 } \\
\text { S.85 } \\
\text { S-86 }\end{array}$} & $\begin{array}{l}2171 \\
2338 \\
2088 \\
2334 \\
2326\end{array}$ \\
\hline & $2251 \pm 115$ \\
\hline
\end{tabular}

Table B.5. Hydraulic activity of S.9 by reaction with alkall

\begin{tabular}{|c|c|}
\hline Sample No. & $\begin{array}{l}\text { Unconfined compressive strength } \\
\text { (psi) }\end{array}$ \\
\hline \multirow[t]{2}{*}{$\begin{array}{l}\text { S.91 } \\
\text { S.92 } \\
\text { S.93 } \\
\text { S.94 } \\
\text { S.95 } \\
\text { S.96 }\end{array}$} & $\begin{array}{l}2 ? 91 \\
2245 \\
2571 \\
2244 \\
2314 \\
2366\end{array}$ \\
\hline & $2355 \pm 122$ \\
\hline
\end{tabular}


60

Table B.6. Hydraulic activity of S.10 by reaction with alkall

\begin{tabular}{|c|c|c|}
\hline Sample No. & $\mathrm{t}$ & $\begin{array}{l}\text { Unconfined compressive strength } \\
\text { (psi) }\end{array}$ \\
\hline \multirow[t]{2}{*}{$\begin{array}{l}\text { S.101 } \\
\text { S.102 } \\
\text { S.104 } \\
\text { S.105 } \\
\text { S.106 }\end{array}$} & & $\begin{array}{l}1498 \\
1558 \\
1435 \\
1456 \\
1509\end{array}$ \\
\hline & Average & $1491 \div 48$ \\
\hline
\end{tabular}

Table B.7. Hydraulic activity of $\$ .11$ by reaction with alkall

\begin{tabular}{|c|c|c|}
\hline Sample No. & & $\begin{array}{l}\text { Unconfined compressive strength } \\
\text { (pal) }\end{array}$ \\
\hline \multirow[t]{2}{*}{$\begin{array}{l}\text { S.111 } \\
\text { S.112 } \\
\text { S.113 } \\
\text { S.114 } \\
\text { S.11S } \\
\text { S.116 }\end{array}$} & & $\begin{array}{l}2480 \\
2550 \\
2545 \\
2510 \\
2523 \\
2635\end{array}$ \\
\hline & Average & $2541 \div 53$ \\
\hline
\end{tabular}


Table B.8. Hydraulic activity of $\$-12$ by reaction with alkall

\begin{tabular}{|c|c|}
\hline Sample No. & $\begin{array}{l}\text { Unconfined compressive strength } \\
\text { (psi) }\end{array}$ \\
\hline \multirow[t]{2}{*}{$\begin{array}{l}S .121 \\
s .122 \\
s .123 \\
s .124 \\
s .125 \\
s .126\end{array}$} & $\begin{array}{l}2508 \\
2595 \\
2543 \\
2445 \\
2490 \\
2505\end{array}$ \\
\hline & $2514 * 51$ \\
\hline
\end{tabular}

Table B.9. Hydraulic activity of $\$ .13$ by reaction with alkali

\begin{tabular}{ll}
\hline Sample No. & $\begin{array}{c}\text { Unconfined compressive strengith } \\
(p s i)\end{array}$ \\
\hline S.131 & 2028 \\
S.132 & 1728 \\
S.133 & 1940 \\
S.134 & 135 \\
S.136 & 1918 \\
& 1950 \\
& 1785 \\
\hline
\end{tabular}


Table B.10. Hydraulle activity of $\mathrm{S}-14$ by reaction with alkall

\begin{tabular}{lc}
\hline Sample No. & $\begin{array}{c}\text { Unconfined compressive strength } \\
(\mathrm{psi})\end{array}$ \\
\hline S.141 & 1373 \\
$\mathrm{~S} \cdot 142$ & 1283 \\
$\mathrm{~S} \cdot 143$ & 1378 \\
$\mathrm{~S} \cdot 144$ & 1230 \\
$\mathrm{~S} \cdot 145$ & 1390 \\
$\mathrm{~S} \cdot 146$ & 1258 \\
& Average \\
\hline
\end{tabular}

Table B.11. Blaine fineness determinations'

\begin{tabular}{|c|c|c|c|c|c|}
\hline \multirow{3}{*}{$\begin{array}{l}\text { Material } \\
\text { C.88 }\end{array}$} & \multicolumn{5}{|c|}{ Blaine fineness $\left(\mathrm{cm}^{3} / \mathrm{g}\right)$} \\
\hline & \multicolumn{3}{|c|}{ Replicate measurements } & \multirow{2}{*}{$\begin{array}{c}\text { Average } \\
\mathbf{3 7 8 8}\end{array}$} & \multirow{2}{*}{$\begin{array}{c}\text { Standard } \\
\text { deviation }\end{array}$} \\
\hline & 3779.6 & 3791.6 & 3791.6 & & \\
\hline $\begin{array}{l}S .6 \\
S .7 \\
S .8 \\
S .9 \\
S .10 \\
S .11 \\
S .12\end{array}$ & $\begin{array}{l}5170.0 \\
6296.0 \\
5684.0 \\
5411.0 \\
3922.0 \\
4271.1 \\
5045.4\end{array}$ & $\begin{array}{l}5194.9 \\
6263.0 \\
5659.0 \\
5668.0 \\
4083.0 \\
4289.2 \\
5035.2\end{array}$ & $\begin{array}{l}\$ 170.0 \\
6260.9 \\
\\
5646.0 \\
3955.0\end{array}$ & $\begin{array}{l}5178 \\
6273 \\
5672 \\
5657 \\
4019 \\
4280 \\
5040\end{array}$ & $\begin{array}{r}14 \\
20 \\
18 \\
16 \\
91 \\
13 \\
7\end{array}$ \\
\hline
\end{tabular}

-ASTM lest method C204-84. 
Table B.12. Isothermal calorimetric data at $80^{\circ} \mathrm{C}$ for matrix components mixed with 101.AW at $9 \mathrm{lb} / \mathrm{gal}$

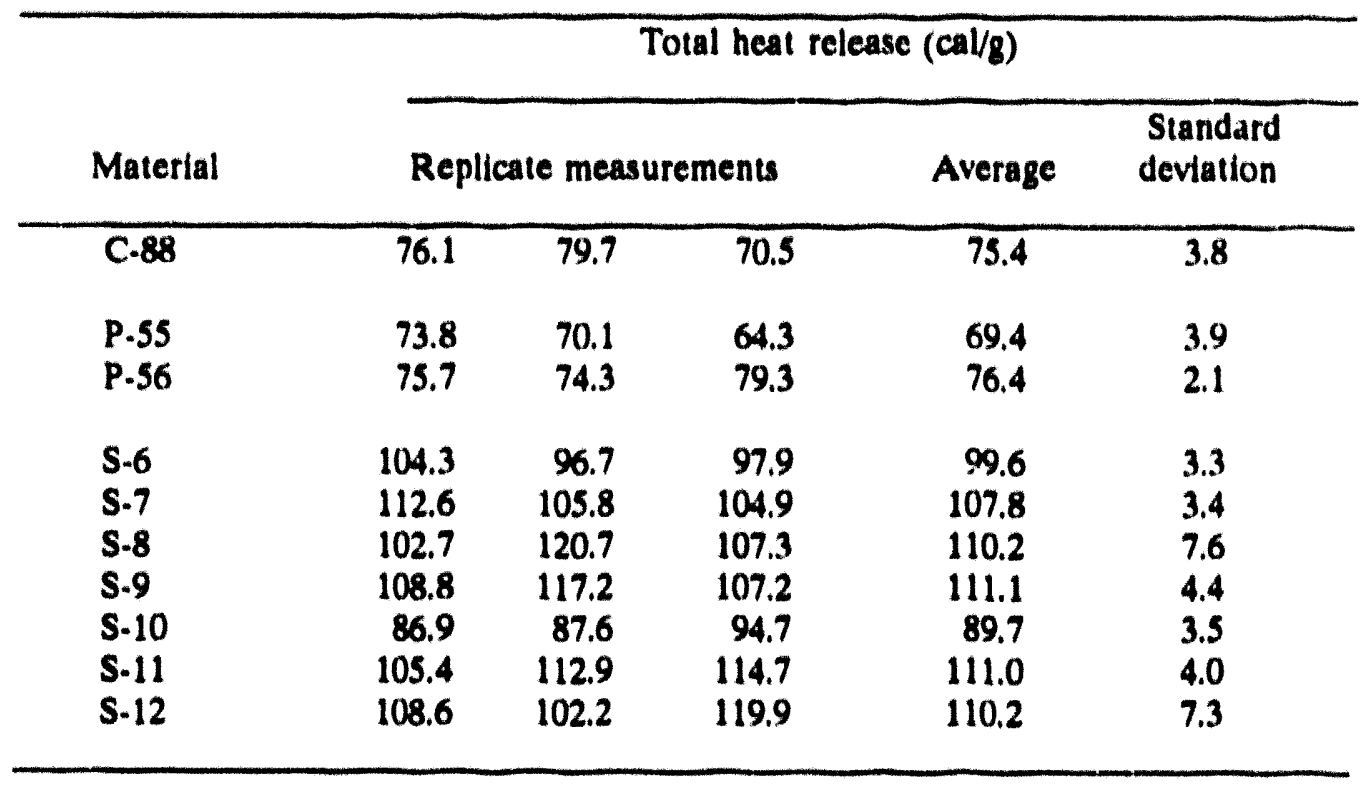


Appendix C. GROUT FORMULATIONS USED IN EXPERIMENTAL MATRIXES 
Table C-1. Grout formulations used in Matrix $1^{\mathrm{a}}$

\begin{tabular}{|c|c|c|c|c|c|c|}
\hline \multirow{2}{*}{$\begin{array}{c}\text { Run } \\
\text { No. }\end{array}$} & \multirow{2}{*}{$\begin{array}{l}\text { Corresponding } \\
\text { Jbservation } \\
\text { No. }\end{array}$} & \multicolumn{4}{|c|}{ Blend composition (wt \%) } & \multirow{2}{*}{$\begin{array}{r}\text { Mix } \\
\text { Ratio } \\
\text { (lb/gal) }\end{array}$} \\
\hline & & Limestone & Fly ash & $\mathrm{BFS}$ & $\overline{\text { Cement }}$ & \\
\hline MX1-1 & 5 & 44.51 & 25.52 & 25.52 & 4.45 & 9.5 \\
\hline $\mathbf{M} \times 1-2$ & 2 & 37.66 & 26.38 & 32.19 & 3.77 & 9.5 \\
\hline $\mathrm{MX1-3}$ & 4 & 35.31 & 30.19 & 30.19 & 4.32 & 8.5 \\
\hline MX1-4 & 3 & 37.66 & 32.19 & 26.38 & 3.77 & 9.5 \\
\hline MX1-5 & 7 & 42.47 & 29.71 & 24.35 & 3.47 & 8.5 \\
\hline MX1-6 & 8 & 40.02 & 27.99 & 27.99 & 4.0 & 9.5 \\
\hline MX1-7 & 1 & 30.63 & 27.76 & 27.76 & 4.84 & 8.5 \\
\hline $\mathrm{MX1-8}$ & 9 & 40.0 & 28.0 & 28.06 & 4.0 & 9.0 \\
\hline $\mathrm{MX1-9}$ & 6 & 42.47 & 24.35 & 29.71 & 3.47 & 8.5 \\
\hline
\end{tabular}

"Materials: limestone, P-59; fly ash, P-55; cement, C-88; and slag, S-8. 
Table C-2. Grout formulations used in Matrix $2^{\mathrm{a}}$

\begin{tabular}{|c|c|c|c|c|c|}
\hline \multirow{2}{*}{$\begin{array}{l}\text { Run } \\
\text { No. }\end{array}$} & \multicolumn{4}{|c|}{ Blend composition (wt \%) } & \multirow{2}{*}{$\begin{array}{c}\text { Mix } \\
\text { ratio } \\
\text { (lb/gal) }\end{array}$} \\
\hline & Limestone & Fly ash & BFS & Cement & \\
\hline $\mathrm{MX2-1}$ & 37.66 & 26.38 & 32.19 & 3.77 & 9.5 \\
\hline $\mathrm{MX2-2}$ & 42.47 & 24.35 & 29.71 & 3.47 & 8.5 \\
\hline $\mathrm{MX2-3}$ & 42.47 & 29.71 & 24.35 & 3.47 & 8.5 \\
\hline $\mathrm{MX2-4}$ & 44.51 & 25.52 & 25.52 & 4.45 & 9.5 \\
\hline $\mathrm{MX2-5}$ & 40.0 & 28.0 & 28.0 & 4.0 & 9.0 \\
\hline $\mathrm{MX2-6}$ & 35.31 & 30.19 & 30.19 & 4.32 & 8.5 \\
\hline $\mathrm{MX} 2-7$ & 40.02 & 27.99 & 27.99 & 4.0 & 9.5 \\
\hline $\mathrm{MX} 2-8$ & 39.63 & 27.76 & 27.76 & 4.84 & 8.5 \\
\hline$M \times 2-9$ & 37.66 & 32.19 & 26.38 & 3.77 & 9.5 \\
\hline
\end{tabular}

'Materials: limestone, P-59; fly ash, P-55; cement, C-88; and slag, S-10. 
69

Table C-3. Grout formulations used in Matrix $3^{2}$

\begin{tabular}{|c|c|c|c|c|c|c|}
\hline \multirow{2}{*}{$\begin{array}{l}\text { Run } \\
\text { No. }\end{array}$} & \multirow{2}{*}{$\begin{array}{l}\text { Corresponding } \\
\text { observation } \\
\text { No. }\end{array}$} & \multicolumn{4}{|c|}{ Blend composition (wt \%) } & \multirow{2}{*}{$\begin{array}{l}\text { Mix } \\
\text { ratio } \\
\text { (lb/gal }\end{array}$} \\
\hline & & Limestone & Fly ash & BFS & Cement & \\
\hline $\mathrm{MX3}-1$ & 5 & 44.51 & 25.52 & 25.52 & 4.45 & 9.5 \\
\hline $\mathrm{MX} 3-2$ & 9 & 40.0 & 28.0 & 28.0 & 4.0 & 9.0 \\
\hline $\mathrm{MX3-3}$ & 8 & 40.02 & 27.99 & 27.99 & 4.0 & 9.5 \\
\hline $\mathrm{MX3.4}$ & 4 & 35.31 & 30.19 & 30.19 & 4.32 & 8.5 \\
\hline MX3-5 & 3 & 37.66 & 32.19 & 26.38 & 3.77 & 9.5 \\
\hline MX3-6 & 2 & 37.66 & 26.38 & 32.19 & 3.77 & 9.5 \\
\hline $\mathrm{MX3-7}$ & 7 & 42.47 & 29.71 & 24.35 & 3.47 & 8.5 \\
\hline $\mathrm{MX3-8}$ & 1 & 39.63 & 29.76 & 27.76 & 4.84 & 8.5 \\
\hline MX3-9 & 6 & 42.47 & 24.35 & 29.71 & 3.47 & 8.5 \\
\hline
\end{tabular}

"Materials: limestone, P-60; fly ash, P-55; cement, C-88; and slag, S-9. 
Table C-4. Grout formulations used in Matrix $4^{a}$

\begin{tabular}{|c|c|c|c|c|c|c|}
\hline \multirow{2}{*}{$\begin{array}{l}\text { Run } \\
\text { No. }\end{array}$} & \multirow{2}{*}{$\begin{array}{l}\text { Corresponding } \\
\text { observation } \\
\text { No. }\end{array}$} & \multicolumn{4}{|c|}{ Blend composition (wt \%) } & \multirow{2}{*}{$\begin{array}{c}\text { Mix } \\
\text { ratio } \\
\text { (lb/gal) }\end{array}$} \\
\hline & & Limestone & Fly ash & BFS & Cement & \\
\hline $\mathrm{MX} 4-1$ & 9 & 40.0 & 28.0 & 28.0 & 4.0 & 9.0 \\
\hline MX4-2 & 2 & 37.66 & 26.38 & 32.19 & 3.77 & 9.5 \\
\hline MX4-3 & 5 & 44.51 & 25.52 & 25.52 & 4.45 & 9.5 \\
\hline MX4-4 & 8 & 40.02 & 27.99 & 27.99 & 4.0 & 9.5 \\
\hline MX4-5 & 1 & 39.63 & 27.76 & 27.76 & 4.84 & 8.5 \\
\hline MX4-6 & 7 & 42.47 & 29.71 & 24.35 & 3.47 & 8.5 \\
\hline MX4-7 & 4 & 35.31 & 30.19 & 30.19 & 4.32 & 8.5 \\
\hline MX4-8 & 3 & 37.66 & 32.19 & 26.38 & 3.77 & 9.5 \\
\hline MX4-9 & 6 & 42.47 & 24.35 & 29.71 & 3.47 & 8.5 \\
\hline
\end{tabular}

"Materials: limestone, P-60; fly ash, P.62; cement, C-88; and slag, S-6. 
71

Table C-5. Grout formulations used in Matrix 5

\begin{tabular}{|c|c|c|c|c|c|c|}
\hline \multirow{2}{*}{$\begin{array}{c}\text { Run } \\
\text { No. }\end{array}$} & \multirow{2}{*}{$\begin{array}{l}\text { Corresponding } \\
\text { observation } \\
\text { No. }\end{array}$} & \multicolumn{4}{|c|}{ Blend composition (wt \%) } & \multirow{2}{*}{$\begin{array}{r}\text { Mix } \\
\text { ratio } \\
\text { (lb/gal) }\end{array}$} \\
\hline & & Limestone & Fly ash & BFS & Cement & \\
\hline MX5.1 & 5 & 44.51 & 25.52 & 25.52 & 4.45 & 9.5 \\
\hline MX5-2 & 7 & 42.47 & 29.71 & 24.35 & 3.47 & 8.5 \\
\hline MX5-3 & 1 & 39.63 & 27.76 & 27.76 & 4.84 & 8.5 \\
\hline $\mathrm{MX5-4}$ & 4 & 35.31 & 30.19 & 30.19 & 4.32 & 8.5 \\
\hline MX5-5 & 3 & 37.66 & 32.19 & 26.38 & 3.77 & 9.5 \\
\hline MX5-6 & 8 & 40.02 & 27.99 & 27.99 & 4.0 & 9.5 \\
\hline MX5-7 & 2 & 37.66 & 26.38 & 32.19 & 3.77 & 9.5 \\
\hline MX5-8 & 9 & 40.0 & 28.0 & 28.0 & 4.0 & 9.0 \\
\hline MX5-9 & 6 & 42.47 & 24.35 & 29.71 & 3.47 & 8.5 \\
\hline
\end{tabular}

"Materials: limestone, P-60; fly ash, P-62; cement, C-88; and BFS, S-7. 
Table C-6. Grout formulations used in Matrix $6^{a}$

\begin{tabular}{|c|c|c|c|c|c|c|}
\hline \multirow{2}{*}{$\begin{array}{c}\text { Run } \\
\text { No. }\end{array}$} & \multirow{2}{*}{$\begin{array}{l}\text { Corresponding } \\
\text { observation } \\
\text { No. }\end{array}$} & \multicolumn{4}{|c|}{ Blend composition (wt \%) } & \multirow{2}{*}{$\begin{array}{l}\text { Mix } \\
\text { ratio } \\
\text { (lb/gal) }\end{array}$} \\
\hline & & Limestone & Fly ash & BFS & Cement & \\
\hline MX6-1 & 8 & 40.02 & 27.99 & 27.99 & 4.0 & 9.5 \\
\hline MX6-2 & 4 & 35.31 & 30.19 & 30.19 & 4.32 & 8.5 \\
\hline MX6-3 & 2 & 37.66 & 26.38 & 32.19 & 3.77 & 9.5 \\
\hline MX6-4 & 3 & 37.66 & 32.19 & 26.38 & 3.77 & 9.5 \\
\hline MX6-5 & 7 & 42.47 & 29.71 & 24.35 & 3.47 & 8.5 \\
\hline MX6.6 & 1 & 39.63 & 27.76 & 27.76 & 4.84 & 8.5 \\
\hline MX6-7 & 9 & 40.0 & 28.0 & 28.0 & 4.0 & 9.0 \\
\hline MX6-8 & 6 & 42.47 & 24.35 & 29.71 & 3.47 & 8.5 \\
\hline MX6-9 & 5 & 44.51 & 25.52 & 25.52 & 4.45 & 9.5 \\
\hline
\end{tabular}

"Materials: limestone, P-60; fly ash, P-62; cement, C-88; and BFS, S-13. 
73

Table C-7. Grout formulations used in Matrix $7^{\mathrm{a}}$

\begin{tabular}{|c|c|c|c|c|c|c|}
\hline \multirow{2}{*}{$\begin{array}{l}\text { Run } \\
\text { No. }\end{array}$} & \multirow{2}{*}{$\begin{array}{l}\text { Corresponding } \\
\text { observation } \\
\text { No. }\end{array}$} & \multicolumn{4}{|c|}{ Blend composition (wt \%) } & \multirow{2}{*}{$\begin{array}{l}\text { Mix } \\
\text { ratio } \\
\text { (lb/gal) }\end{array}$} \\
\hline & & Limestone & Fly ash & BFS & Cement & \\
\hline MX7-1 & 8 & 40.02 & 27.99 & 27.99 & 4.0 & 9.5 \\
\hline$M \times 7-2$ & 5 & 44.51 & 25.52 & 25.52 & 4.45 & 9.5 \\
\hline$M \times 7-3$ & 9 & 40.0 & 28.0 & 28.0 & 4.0 & 9.0 \\
\hline$M \times 7-4$ & 7 & 42.47 & 29.71 & 24.35 & 3.47 & 8.5 \\
\hline MX7.5 & 4 & 35.31 & 30.19 & 30.19 & 4.32 & 8.5 \\
\hline$M \times 7-6$ & 2 & 37.66 & 26.38 & 32.19 & 3.77 & 9.5 \\
\hline$M \times 7-7$ & 6 & 42.47 & 24.35 & 29.71 & 3.47 & 8.5 \\
\hline$M \times 7-8$ & 3 & 37.66 & 32.19 & 26.38 & 3.77 & 9.5 \\
\hline$M \times 7-9$ & 1 & 39.63 & 27.76 & 27.76 & 4.84 & 8.5 \\
\hline
\end{tabular}

"Materials: limestone, Jim Bridger ash, cement Type I-II-LA, and slag S-13. 
74

Table C.8. Grout formulations used in Matrix $\mathbf{8}^{\prime}$

\begin{tabular}{|c|c|c|c|c|c|c|}
\hline \multirow{2}{*}{$\begin{array}{l}\text { Run } \\
\text { No. }\end{array}$} & \multirow{2}{*}{$\begin{array}{c}\text { Corresponding } \\
\text { observation } \\
\text { No. }\end{array}$} & \multicolumn{4}{|c|}{ Blend composition (wt \%) } & \multirow{2}{*}{$\begin{array}{l}\text { Mix } \\
\text { ratio } \\
\text { (lb/gal) }\end{array}$} \\
\hline & & Limestone & Fly ash & BFS & $\overline{\text { Cement }}$ & \\
\hline MX8-1 & 8 & 40.02 & 27.99 & 27.99 & 4.0 & 9.5 \\
\hline $\mathrm{MX8-2}$ & 4 & 35.31 & 30.19 & 30.19 & 4.32 & 8.5 \\
\hline MX8-3 & 5 & 44.51 & 25.52 & 25.52 & 4.45 & 9.5 \\
\hline MX8-4 & 9 & 40.0 & 28.0 & 28.0 & 4.0 & 9.0 \\
\hline MX8.5 & 6 & 42.47 & 24.35 & 29.71 & 3.47 & 8.5 \\
\hline MX8-6 & 7 & 42.47 & 29.71 & 24.35 & 3.47 & 8.5 \\
\hline MX8-7 & 1 & 39.63 & 27.76 & 27.76 & 4.84 & 8.5 \\
\hline MX8-8 & 3 & 37.66 & 32.19 & 26.38 & 3.77 & 9.5 \\
\hline MX8.9 & 2 & 37.66 & 26.38 & 32.19 & 3.77 & 9.5 \\
\hline
\end{tabular}

"Materials: limestone flour, Jim Bridger ash, Cement Type I-lI-LA, and slag S.7. 
75

Table C.9. Grout formulations used in Matrix $9^{*}$

\begin{tabular}{|c|c|c|c|c|c|c|}
\hline \multirow{2}{*}{$\begin{array}{c}\text { Run } \\
\text { No. }\end{array}$} & \multirow{2}{*}{$\begin{array}{c}\text { Corresponding } \\
\text { observation } \\
\text { No. }\end{array}$} & \multicolumn{4}{|c|}{ Blend composition (wr \%) } & \multirow{2}{*}{$\begin{array}{l}\text { MLx } \\
\text { ratio } \\
\text { (lb/gal) }\end{array}$} \\
\hline & & Limestone & Fly ash & BFS & Cement & \\
\hline MX9-1 & 5 & 44.51 & 25.52 & 25.52 & 4.45 & 9.5 \\
\hline MX9.2 & 1 & 39.63 & 27.76 & 27.76 & 4.84 & 8.5 \\
\hline MX9-3 & 7 & 42.47 & 29.71 & 24.35 & 3.47 & 8.5 \\
\hline MX9.4 & 2 & 37.66 & 26.38 & 32.19 & 3.77 & 9.5 \\
\hline MX9.5 & 9 & 40.0 & 28.0 & 28.0 & 4.0 & 9.0 \\
\hline MX9.6 & 4 & 35.31 & 30.19 & 30.19 & 4.32 & 8.5 \\
\hline MX9.7 & 8 & 40.02 & 27.99 & 27.99 & 4.0 & 9.5 \\
\hline MX9-8 & 6 & 42.47 & 24.35 & 29.71 & 3.47 & 8.5 \\
\hline MX9.9 & 3 & 37.66 & 32.19 & 26.38 & 3.77 & 9.5 \\
\hline
\end{tabular}

"Materials: limestone flour, Jim Bridger ash, cement Type I-II-LA, and slag S-14. 
Table C.10. Grout formulations used in Matrix $10^{\circ}$

\begin{tabular}{|c|c|c|c|c|c|c|}
\hline \multirow{2}{*}{$\begin{array}{c}\text { Run } \\
\text { No. }\end{array}$} & \multirow{2}{*}{$\begin{array}{l}\text { Corresponding } \\
\text { observation } \\
\text { No. }\end{array}$} & \multicolumn{4}{|c|}{ Blend composition (w g) } & \multirow{2}{*}{$\begin{array}{c}\text { Mix } \\
\text { ralio } \\
\text { (lb/gal) }\end{array}$} \\
\hline & & Limestone & Fly ash & BFS & Cement & \\
\hline$M \times 10-1$ & 9 & 40.0 & 28.0 & 28.0 & 4.0 & 9.0 \\
\hline $\mathrm{M} \times 10-2$ & 2 & 37.66 & 26.38 & 32.19 & 3.77 & 9.5 \\
\hline$M \times 10-3$ & 5 & 44.51 & 25.52 & 25.52 & 4.45 & 9.5 \\
\hline$M \times 10.4$ & 8 & 40.02 & 27.99 & 27.99 & 4.0 & 9.5 \\
\hline$M \times 10.5$ & 1 & 39.63 & 27.76 & 27.76 & 4.84 & 8.5 \\
\hline MX10.6 & 7 & $4<.47$ & 29.71 & 24.35 & 3.47 & 8.5 \\
\hline$M \times 10-7$ & 4 & 35.31 & 30.19 & 30.19 & 4.32 & 8.5 \\
\hline$M \times 10-8$ & 3 & 37.66 & 32.19 & 26.38 & 3.77 & 9.5 \\
\hline$M \times 10.9$ & 6 & 42.47 & 24.35 & 29.71 & 3.47 & 8.5 \\
\hline
\end{tabular}
slag S-6.

Materials: limestone ground, Centralia fly ash, cement Type I.11.LA, and 
77

Table C.11. Orout formulations used in Matrix 11"

\begin{tabular}{|c|c|c|c|c|c|c|}
\hline \multirow{2}{*}{$\begin{array}{l}\text { Run } \\
\text { No. }\end{array}$} & \multirow{2}{*}{$\begin{array}{c}\text { Corresponding } \\
\text { observation } \\
\text { No. }\end{array}$} & \multicolumn{4}{|c|}{ Blend composillon $\left(x+\sigma_{0}\right)$} & \multirow{2}{*}{$\begin{array}{l}\text { Mix } \\
\text { ratio } \\
\text { (lb/gal) }\end{array}$} \\
\hline & & Limastone & Fy wh & BFS & Cement & \\
\hline$M \times 11.1$ & 9 & 40.0 & 28.0 & 28.0 & 4.0 & 9.0 \\
\hline $\mathrm{M} \times 11.2$ & 2 & 37.66 & 26.38 & 32.19 & 3,77 & 9.5 \\
\hline $\mathrm{M} \times 11.3$ & $\mathbf{s}$ & 44.51 & 25.52 & 25.52 & 4.45 & 9.5 \\
\hline $\mathrm{MX} 11.4$ & 8 & 40.02 & 27.99 & 27.99 & 4.0 & 9.5 \\
\hline$M \times 11.5$ & 7 & 42.47 & 29.71 & 24.35 & 3.47 & 8.5 \\
\hline$M \times 11.6$ & 4 & 35.31 & 30.19 & 30.19 & 4.32 & 8.5 \\
\hline$M \times 11.7$ & 3 & 37.66 & 32.19 & 26.38 & 3.77 & 9.5 \\
\hline MX11.8 & 1 & 39.63 & 27.76 & 27.76 & 4.84 & 8.5 \\
\hline MX11.9 & 6 & 42.47 & 24.35 & 29.71 & 3.47 & 8.5 \\
\hline
\end{tabular}
slag S.14. 
Table C.12. Grout formulations used In Matrix 124

\begin{tabular}{|c|c|c|c|c|c|c|}
\hline \multirow{2}{*}{$\begin{array}{l}\text { Run } \\
\text { No. }\end{array}$} & \multirow{2}{*}{$\begin{array}{l}\text { Corresponding } \\
\text { observation } \\
\text { No. }\end{array}$} & \multicolumn{4}{|c|}{ Blend composilion (w $\%$ ) } & \multirow{2}{*}{$\begin{array}{c}\text { Mix } \\
\text { ratio } \\
(\mathrm{lb} / \mathrm{gal})\end{array}$} \\
\hline & & Limestone & Fly ash & BFS & Cement & \\
\hline MX12.1 & 8 & 40.02 & 27.99 & 27.99 & 4.0 & 9.5 \\
\hline$M \times 12.2$ & 1 & 39.63 & 27.76 & 27.76 & 4.84 & 8.5 \\
\hline$M \times 12.3$ & 7 & 42.47 & 29.71 & 24.35 & 3.47 & 8.5 \\
\hline$M \times 12.4$ & 9 & 40.0 & 28.0 & 28.0 & 4.0 & 9.0 \\
\hline$M \times 12.5$ & 3 & 37.66 & 32.19 & 26.38 & 3.77 & 9.5 \\
\hline$M \times 12.6$ & 2 & 37.66 & 26.38 & 32.19 & 3.77 & 9.5 \\
\hline$M \times 12.7$ & 5 & 4.51 & 25.52 & 25.52 & 4.45 & 9.5 \\
\hline $\mathrm{MX} 12.8$ & 6 & 42.47 & 24.35 & 29.71 & 3.47 & 8.5 \\
\hline$M \times 12.9$ & 4 & 35.31 & 30.19 & 30.19 & 4.32 & 8.5 \\
\hline
\end{tabular}

"Materials: limestone nour, Centralia ash, slag S.8, and

Type 1.II cement from LaFarge Corp. 
Table C-13. Grout formulations used in Matrix 13"

\begin{tabular}{|c|c|c|c|c|c|}
\hline \multirow{2}{*}{$\begin{array}{c}\text { Run } \\
\text { No. }\end{array}$} & \multirow{2}{*}{$\begin{array}{l}\text { Corresponding } \\
\text { observation } \\
\text { No. }\end{array}$} & \multicolumn{3}{|c|}{ Blend composition (wt \%) } & \multirow{2}{*}{$\begin{array}{l}\text { Mix } \\
\text { ratio } \\
\text { (Ib/gal) }\end{array}$} \\
\hline & & Limestone & BFS & Cement & \\
\hline $\mathrm{MX13.1}$ & 2 & 37.66 & 32.19 & 3.77 & 9.5 \\
\hline$M \times 13.2$ & 7 & 42.47 & 24.35 & 3.47 & 8.5 \\
\hline $\mathrm{M} \times 13.3$ & 5 & 44.51 & 25.52 & 4.45 & 9.5 \\
\hline$M \times 13.4$ & 3 & 37.66 & 26.38 & 3.77 & 9.5 \\
\hline $\mathrm{M} \times 13.5$ & 6 & 42.47 & 29.71 & 3.47 & 8.5 \\
\hline $\mathrm{MX13.6}$ & 8 & 40.02 & 27.99 & 4.0 & 9.5 \\
\hline $\mathrm{MX13.7}$ & 4 & 35.31 & 30.19 & 4.32 & 8.5 \\
\hline$M \times 13-8$ & 1 & 39.63 & 27.76 & 4.84 & 8.5 \\
\hline MX13.9 & 9 & 40.0 & 28.0 & 4.0 & 9.0 \\
\hline
\end{tabular}

"Materials: limestone flour, Centralla ash, slag S.11, and

Type I.II cement from LaFarge Corp. 
Appendix D. FLUID-GROUT DATA FOR ALL EXPERIMENTAL RUNS 
83

Table D-1. Properties of fluid grouts prepared from Matrix 1

\begin{tabular}{|c|c|c|c|c|c|c|}
\hline & $\begin{array}{l}\text { Corresponding } \\
\text { observation } \\
\text { No. }\end{array}$ & $\begin{array}{l}\text { Critical } \\
\text { velocity } \\
\text { (gal/min) }\end{array}$ & $\begin{array}{l}\text { Frictional } \\
\text { pressure } \\
\text { drop } \\
(\text { psi } / 100 \mathrm{ft})\end{array}$ & $\begin{array}{l}\text { Pump-head } \\
\text { pressure } \\
\text { (psi) }\end{array}$ & $\begin{array}{c}10 \text {-min gel } \\
\text { strength } \\
\left(1 \mathrm{~b}_{\mathrm{f}} / 100 \mathrm{ft}^{2}\right)\end{array}$ & $\begin{array}{l}\text { Density } \\
\text { (lb/gal) }\end{array}$ \\
\hline $\begin{array}{l}M X 1-1-A \\
M X 1-1-B \\
M X 1-1-C\end{array}$ & 5 & $\begin{array}{l}14.7 \\
15.0 \\
14.7\end{array}$ & $\begin{array}{l}5.7 \\
5.7 \\
5.6\end{array}$ & $\begin{array}{l}2.0 \\
1.9 \\
2.4\end{array}$ & $\begin{array}{l}5.6 \\
5.2 \\
6.7\end{array}$ & $\begin{array}{l}13.5 \\
13.5 \\
13.4\end{array}$ \\
\hline $\begin{array}{l}M X 1-2-A \\
M X 1-2-B \\
M X 1-2-C\end{array}$ & 2 & $\begin{array}{l}15.5 \\
15.8 \\
15.1\end{array}$ & $\begin{array}{l}5.7 \\
5.7 \\
5.7\end{array}$ & $\begin{array}{l}3.5 \\
3.0 \\
3.1\end{array}$ & $\begin{array}{l}9.5 \\
8.1 \\
8.5\end{array}$ & $\begin{array}{l}13.5 \\
13.5 \\
13.5\end{array}$ \\
\hline $\begin{array}{l}M X 1-3-A \\
M X 1-3-B \\
M X 1-3-C\end{array}$ & 4 & $\begin{array}{l}12.5 \\
19.8 \\
14.0\end{array}$ & $\begin{array}{l}5.5 \\
5.5 \\
5.5\end{array}$ & $\begin{array}{l}2.6 \\
2.4 \\
2.6\end{array}$ & $\begin{array}{l}7.0 \\
6.5 \\
7.0\end{array}$ & $\begin{array}{l}13.2 \\
13.2 \\
13.2\end{array}$ \\
\hline $\begin{array}{l}\text { MX1-4-A } \\
\text { MX1-4-B } \\
\text { MX1-4-C }\end{array}$ & 3 & $\begin{array}{l}15.6 \\
14.5 \\
14.4\end{array}$ & $\begin{array}{l}5.6 \\
5.6 \\
5.6\end{array}$ & $\begin{array}{l}2.5 \\
2.6 \\
2.5\end{array}$ & $\begin{array}{l}6.8 \\
7.0 \\
6.8\end{array}$ & $\begin{array}{l}13.3 \\
13.3 \\
13.4\end{array}$ \\
\hline $\begin{array}{l}\text { MX1-5-A } \\
\text { MX1-5-B } \\
M X 1-5-C\end{array}$ & 7 & $\begin{array}{l}12.7 \\
12.7 \\
13.9\end{array}$ & $\begin{array}{l}5.5 \\
5.5 \\
5.5\end{array}$ & $\begin{array}{l}1.6 \\
1.6 \\
1.9\end{array}$ & $\begin{array}{l}4.5 \\
4.5 \\
5.2\end{array}$ & $\begin{array}{l}13.2 \\
13.2 \\
13.2\end{array}$ \\
\hline $\begin{array}{l}\text { MX1-6-A } \\
\text { MX1-6-B } \\
\text { MX1-6-C }\end{array}$ & 8 & $\begin{array}{l}15.4 \\
15.6 \\
15.0\end{array}$ & $\begin{array}{l}5.7 \\
5.7 \\
5.7\end{array}$ & $\begin{array}{l}2.4 \\
2.0 \\
2.4\end{array}$ & $\begin{array}{l}6.5 \\
5.5 \\
6.5\end{array}$ & $\begin{array}{l}13.5 \\
13.5 \\
13.5\end{array}$ \\
\hline $\begin{array}{l}\text { MX1-7-A } \\
M X 1-7-B \\
M X 1-7-C\end{array}$ & 1 & $\begin{array}{l}13.2 \\
13.5 \\
13.2\end{array}$ & $\begin{array}{l}5.5 \\
5.5 \\
5.5\end{array}$ & $\begin{array}{l}2.0 \\
2.0 \\
2.4\end{array}$ & $\begin{array}{l}5.5 \\
5.5 \\
6.5\end{array}$ & $\begin{array}{l}13.2 \\
13.2 \\
13.2\end{array}$ \\
\hline $\begin{array}{l}\text { MX1-8-A } \\
\text { MX1-8-B } \\
\text { MX1-8-C }\end{array}$ & 9 & $\begin{array}{l}13.4 \\
14.8 \\
14.6\end{array}$ & $\begin{array}{l}5.6 \\
5.6 \\
5.6\end{array}$ & $\begin{array}{l}2.1 \\
2.3 \\
2.4\end{array}$ & $\begin{array}{l}5.8 \\
6.2 \\
6.5\end{array}$ & $\begin{array}{l}13.3 \\
13.3 \\
13.4\end{array}$ \\
\hline $\begin{array}{l}\text { MX1-9-A } \\
\text { MX1-9-B } \\
\text { MX1-9-C }\end{array}$ & 6 & $\begin{array}{l}12.7 \\
13.8 \\
13.3\end{array}$ & $\begin{array}{l}5.6 \\
5.6 \\
5.6 \\
\end{array}$ & $\begin{array}{r}12.4 \\
35.0 \\
5.6\end{array}$ & $\begin{array}{l}34.0 \\
96.0 \\
15.5\end{array}$ & $\begin{array}{l}13.3 \\
13.3 \\
13.3\end{array}$ \\
\hline
\end{tabular}


Table D-2. Properties of fluid grouts prepared from Matrix 2

\begin{tabular}{|c|c|c|c|c|c|c|}
\hline $\begin{array}{r}\text { Run } \\
\text { No. }\end{array}$ & $\begin{array}{l}\text { Corresponding } \\
\text { observation } \\
\text { No. }\end{array}$ & $\begin{array}{c}\text { Critical } \\
\text { velocity } \\
\text { (gal/min) }\end{array}$ & $\begin{array}{c}\text { Frictional } \\
\text { pressure } \\
\text { drop } \\
(\mathrm{psi} / 100 \mathrm{ft}) \\
\end{array}$ & $\begin{array}{c}\text { Pump-head } \\
\text { pressure } \\
\text { (psi) }\end{array}$ & $\begin{array}{c}\text { 10-min gel } \\
\text { strength } \\
\left(\mathrm{lb}_{\mathrm{f}} / 100 \mathrm{ft}^{2}\right)\end{array}$ & $\begin{array}{l}\text { Density } \\
\text { (lb/gal) }\end{array}$ \\
\hline $\begin{array}{l}\text { MX2-1-A } \\
M \times 2-1-B \\
M \times 2-1-C\end{array}$ & 8 & $\begin{array}{l}13.7 \\
13.6 \\
12.6\end{array}$ & $\begin{array}{l}5.7 \\
5.7 \\
5.7\end{array}$ & $\begin{array}{l}2.4 \\
2.4 \\
2.2\end{array}$ & $\begin{array}{l}6.5 \\
6.5 \\
6.0\end{array}$ & $\begin{array}{l}13.6 \\
13.6 \\
13.6\end{array}$ \\
\hline $\begin{array}{l}M X 2-2-A \\
M X 2-2-B \\
M X 2-2-C\end{array}$ & 1 & $\begin{array}{l}11.9 \\
11.9 \\
12.0\end{array}$ & $\begin{array}{l}5.6 \\
5.6 \\
5.6\end{array}$ & $\begin{array}{l}1.6 \\
2.2 \\
2.2\end{array}$ & $\begin{array}{l}4.5 \\
6.0 \\
6.0\end{array}$ & $\begin{array}{l}13.3 \\
13.3 \\
13.3\end{array}$ \\
\hline $\begin{array}{l}M \times 2-3-A \\
M \times 2-3-B \\
M X 2-3-C\end{array}$ & 9 & $\begin{array}{l}12.4 \\
12.2 \\
12.4\end{array}$ & $\begin{array}{l}5.6 \\
5.6 \\
5.6\end{array}$ & $\begin{array}{l}2.6 \\
2.6 \\
2.7\end{array}$ & $\begin{array}{l}7.0 \\
7.0 \\
7.5\end{array}$ & $\begin{array}{l}13.2 \\
13.3 \\
13.3\end{array}$ \\
\hline $\begin{array}{l}M \times 2-4-A \\
M \times 2-4-B \\
M \times 2-4-C\end{array}$ & 6 & $\begin{array}{l}14.6 \\
14.3 \\
14.1\end{array}$ & $\begin{array}{l}5.7 \\
5.7 \\
5.7\end{array}$ & $\begin{array}{l}4.4 \\
4.0 \\
4.2\end{array}$ & $\begin{array}{l}12.0 \\
11.0 \\
11.5\end{array}$ & $\begin{array}{l}13.6 \\
13.6 \\
13.6\end{array}$ \\
\hline $\begin{array}{l}M \times 2-5-A \\
M \times 2-5-B \\
M \times 2-5-C\end{array}$ & 4 & $\begin{array}{l}13.2 \\
14.4 \\
14.0\end{array}$ & $\begin{array}{l}5.7 \\
5.7 \\
5.7\end{array}$ & $\begin{array}{l}3.1 \\
4.9 \\
3.8\end{array}$ & $\begin{array}{r}8.5 \\
13.5 \\
10.5\end{array}$ & $\begin{array}{l}13.6 \\
13.5 \\
13.5\end{array}$ \\
\hline $\begin{array}{l}M X 2-6-A \\
M X 2-6-B \\
M \times 2-6-C\end{array}$ & 2 & $\begin{array}{l}13.5 \\
12.4 \\
12.4\end{array}$ & $\begin{array}{l}5.6 \\
5.6 \\
5.6\end{array}$ & $\begin{array}{l}1.8 \\
1.6 \\
1.5\end{array}$ & $\begin{array}{l}5.0 \\
4.5 \\
4.2\end{array}$ & $\begin{array}{l}13.3 \\
13.3 \\
13.4\end{array}$ \\
\hline $\begin{array}{l}M \times 2-7-A \\
M \times 2-7-B \\
M \times 2-7-C\end{array}$ & 3 & $\begin{array}{l}14.5 \\
14.7 \\
13.9\end{array}$ & $\begin{array}{l}5.7 \\
5.7 \\
5.7\end{array}$ & $\begin{array}{l}2.6 \\
2.0 \\
2.3\end{array}$ & $\begin{array}{l}7.0 \\
5.5 \\
6.2\end{array}$ & $\begin{array}{l}13.6 \\
13.6 \\
13.6\end{array}$ \\
\hline $\begin{array}{l}\text { MX2-8-A } \\
M X 2-8-B \\
M X 2-8-C\end{array}$ & 7 & $\begin{array}{l}13.5 \\
13.5 \\
14.0\end{array}$ & $\begin{array}{l}5.6 \\
5.6 \\
5.7\end{array}$ & $\begin{array}{l}3.3 \\
3.6 \\
4.2\end{array}$ & $\begin{array}{r}9.0 \\
10.0 \\
11.4\end{array}$ & $\begin{array}{l}13.4 \\
13.4 \\
13.5\end{array}$ \\
\hline $\begin{array}{l}\text { MX2-9-A } \\
M X 2-9-B \\
M X 2-9-C\end{array}$ & 5 & $\begin{array}{l}15.6 \\
15.8 \\
15.9 \\
\end{array}$ & $\begin{array}{l}5.8 \\
5.8 \\
5.7 \\
\end{array}$ & $\begin{array}{l}5.5 \\
6.9 \\
6.0 \\
\end{array}$ & $\begin{array}{l}15.0 \\
19.0 \\
16.5 \\
\end{array}$ & $\begin{array}{l}13.7 \\
13.7 \\
13.7\end{array}$ \\
\hline
\end{tabular}


85

Table D-3. Properties of fluid grouts prepared from Matrix 2R

\begin{tabular}{|c|c|c|c|c|c|}
\hline $\begin{array}{l}\text { Run } \\
\text { No. }\end{array}$ & $\begin{array}{c}\text { Critical } \\
\text { velocity } \\
\text { (gal/min) }\end{array}$ & $\begin{array}{l}\text { Frictional } \\
\text { pressure } \\
\text { drop } \\
\text { (psi/100 ft) }\end{array}$ & $\begin{array}{l}\text { Pump-head } \\
\text { pressure } \\
\text { (psi) }\end{array}$ & $\begin{array}{c}10 \text {-min gel } \\
\text { strength } \\
\left(1 \mathrm{~b}_{\mathrm{f}} / 100 \mathrm{ft}^{2}\right)\end{array}$ & $\begin{array}{l}\text { Density } \\
\text { (lb/gal) }\end{array}$ \\
\hline $\begin{array}{l}\text { MX2R-1-A } \\
\text { MX2R-1-B } \\
\text { MX2R-1-C }\end{array}$ & $\begin{array}{l}14.4 \\
14.4 \\
14.1\end{array}$ & $\begin{array}{l}5.6 \\
5.6 \\
5.6\end{array}$ & $\begin{array}{l}1.6 \\
1.3 \\
1.6\end{array}$ & $\begin{array}{l}4.5 \\
3.5 \\
4.5\end{array}$ & $\begin{array}{l}13.4 \\
13.4 \\
13.4\end{array}$ \\
\hline $\begin{array}{l}\text { MX2R-2-A } \\
\text { MX2R-2-B } \\
\text { MX2R-2-C }\end{array}$ & $\begin{array}{l}12.1 \\
12.4 \\
11.2\end{array}$ & $\begin{array}{l}5.5 \\
5.5 \\
5.5\end{array}$ & $\begin{array}{l}1.3 \\
1.3 \\
1.3\end{array}$ & $\begin{array}{l}3.5 \\
3.5 \\
3.5\end{array}$ & $\begin{array}{l}13.1 \\
13.1 \\
13.1\end{array}$ \\
\hline $\begin{array}{l}\text { MX2R-3-A } \\
M X 2 R-3-B \\
M X 2 R-3-C\end{array}$ & $\begin{array}{l}11.6 \\
12.7 \\
12.4\end{array}$ & $\begin{array}{l}5.5 \\
5.5 \\
5.5\end{array}$ & $\begin{array}{l}1.1 \\
1.3 \\
1.1\end{array}$ & $\begin{array}{l}3.0 \\
3.5 \\
3.0\end{array}$ & $\begin{array}{l}13.0 \\
13.1 \\
13.0\end{array}$ \\
\hline $\begin{array}{l}\text { MX2R-4-A } \\
M X 2 R-4-B \\
M X 2 R-4-C\end{array}$ & $\begin{array}{l}15.0 \\
14.9 \\
15.1\end{array}$ & $\begin{array}{l}5.6 \\
5.6 \\
5.6\end{array}$ & $\begin{array}{l}2.0 \\
1.6 \\
1.8\end{array}$ & $\begin{array}{l}5.5 \\
4.5 \\
5.0\end{array}$ & $\begin{array}{l}13.4 \\
13.4 \\
13.4\end{array}$ \\
\hline $\begin{array}{l}\text { MX2R-5-A } \\
\text { MX2R-5-B } \\
\text { MX2R-5-C }\end{array}$ & $\begin{array}{l}13.5 \\
14.5 \\
14.2\end{array}$ & $\begin{array}{l}5.6 \\
5.5 \\
5.6\end{array}$ & $\begin{array}{l}1.3 \\
1.3 \\
1.3\end{array}$ & $\begin{array}{l}3.5 \\
3.5 \\
3.5\end{array}$ & $\begin{array}{l}13.2 \\
13.2 \\
13.2\end{array}$ \\
\hline $\begin{array}{l}\text { MX2R-6-A } \\
\text { MX2R-6-B } \\
M X 2 R-6-C\end{array}$ & $\begin{array}{l}13.9 \\
13.8 \\
11.9\end{array}$ & $\begin{array}{l}5.5 \\
5.5 \\
5.5\end{array}$ & $\begin{array}{l}1.3 \\
1.3 \\
1.1\end{array}$ & $\begin{array}{l}3.5 \\
3.5 \\
3.0\end{array}$ & $\begin{array}{l}13.0 \\
13.0 \\
13.0\end{array}$ \\
\hline $\begin{array}{l}\text { MX2R-7-A } \\
\text { MX2R-7-B } \\
\text { MX2R-7-C }\end{array}$ & $\begin{array}{l}15.3 \\
14.3 \\
14.7\end{array}$ & $\begin{array}{l}5.6 \\
5.6 \\
5.6\end{array}$ & $\begin{array}{l}1.6 \\
1.8 \\
1.6\end{array}$ & $\begin{array}{l}4.5 \\
5.0 \\
4.5\end{array}$ & $\begin{array}{l}13.4 \\
13.4 \\
13.4\end{array}$ \\
\hline $\begin{array}{l}\text { MX2R-8-A } \\
\text { MX2R-8-B } \\
\text { MX2R-8-C }\end{array}$ & $\begin{array}{l}13.5 \\
12.9 \\
12.6\end{array}$ & $\begin{array}{l}5.5 \\
5.5 \\
5.5\end{array}$ & $\begin{array}{l}1.5 \\
1.1 \\
1.3\end{array}$ & $\begin{array}{l}4.0 \\
3.0 \\
3.5\end{array}$ & $\begin{array}{l}13.1 \\
13.1 \\
13.1\end{array}$ \\
\hline $\begin{array}{l}\text { MX2R-9-A } \\
\text { MX2R-9-B } \\
\text { MX2R-9-C }\end{array}$ & $\begin{array}{l}14.4 \\
14.2 \\
14.3\end{array}$ & $\begin{array}{l}5.6 \\
5.6 \\
5.6\end{array}$ & $\begin{array}{l}1.6 \\
1.6 \\
1.5\end{array}$ & $\begin{array}{l}4.5 \\
4.5 \\
4.0\end{array}$ & $\begin{array}{l}13.4 \\
13.4 \\
13.4\end{array}$ \\
\hline
\end{tabular}


Tuble D-4. Properties of fluid grouts prepared from Matrix 3

\begin{tabular}{|c|c|c|c|c|c|}
\hline $\begin{array}{c}\text { Run } \\
\text { No. }\end{array}$ & $\begin{array}{l}\text { Critical } \\
\text { velocity } \\
(\mathrm{gal} / \mathrm{min})\end{array}$ & $\begin{array}{l}\text { Frictional } \\
\text { pressure } \\
\text { drop } \\
\text { (psi/100 ft) }\end{array}$ & $\begin{array}{c}\text { Pump-head } \\
\text { pressure } \\
\text { (psi) }\end{array}$ & $\begin{array}{l}10 \text {-min gel } \\
\text { strength } \\
\left(1 \mathrm{~b}_{\mathrm{f}} / 100 \mathrm{ft}^{2}\right)\end{array}$ & $\begin{array}{l}\text { Density } \\
\text { (lb/gal) }\end{array}$ \\
\hline $\begin{array}{l}\text { MX3-1-A } \\
\text { MX3-1-B } \\
\text { MX3-1-C }\end{array}$ & $\begin{array}{l}14.9 \\
15.3 \\
15.4\end{array}$ & $\begin{array}{l}5.7 \\
5.7 \\
5.7\end{array}$ & $\begin{array}{l}5.6 \\
5.1 \\
5.5\end{array}$ & $\begin{array}{l}15.5 \\
14.0 \\
15.0\end{array}$ & $\begin{array}{l}13.6 \\
13.6 \\
13.5\end{array}$ \\
\hline $\begin{array}{l}\text { MX3-2-A } \\
M \times 3-2-B \\
M \times 3-2-C\end{array}$ & $\begin{array}{l}14.6 \\
14.0 \\
13.8\end{array}$ & $\begin{array}{l}5.6 \\
5.6 \\
5.6\end{array}$ & $\begin{array}{l}4.4 \\
5.1 \\
4.7\end{array}$ & $\begin{array}{l}12.0 \\
14.0 \\
13.0\end{array}$ & $\begin{array}{l}13.4 \\
13.4 \\
13.4\end{array}$ \\
\hline $\begin{array}{l}M X 3-3-A \\
M X 3-3-B \\
M X 3-3-C\end{array}$ & $\begin{array}{l}14.7 \\
15.3 \\
15.0\end{array}$ & $\begin{array}{l}5.7 \\
5.7 \\
5.7\end{array}$ & $\begin{array}{l}8.4 \\
5.3 \\
6.9\end{array}$ & $\begin{array}{l}23.0 \\
14.5 \\
19.0\end{array}$ & $\begin{array}{l}13.6 \\
13.6 \\
13.6\end{array}$ \\
\hline $\begin{array}{l}\text { MX3-4-A } \\
M X 3-4-B \\
M X 3-4-C\end{array}$ & $\begin{array}{l}13.8 \\
13.0 \\
13.8\end{array}$ & $\begin{array}{l}5.6 \\
5.6 \\
5.6\end{array}$ & $\begin{array}{l}5.5 \\
4.4 \\
3.8\end{array}$ & $\begin{array}{l}15.0 \\
12.0 \\
10.5\end{array}$ & $\begin{array}{l}13.3 \\
13.3 \\
13.3\end{array}$ \\
\hline $\begin{array}{l}M \times 3-5-A \\
M X 3-5-B \\
M \times 3-5-C\end{array}$ & $\begin{array}{l}16.1 \\
16.2 \\
15.7\end{array}$ & $\begin{array}{l}5.7 \\
5.7 \\
5.7\end{array}$ & $\begin{array}{l}5.6 \\
4.7 \\
4.7\end{array}$ & $\begin{array}{l}15.5 \\
13.0 \\
13.0\end{array}$ & $\begin{array}{l}13.5 \\
13.5 \\
13.5\end{array}$ \\
\hline $\begin{array}{l}M \times 3-6-A \\
M \times 3-6-B \\
M \times 3-6-C\end{array}$ & $\begin{array}{l}16.7 \\
17.1 \\
17.2\end{array}$ & $\begin{array}{l}5.7 \\
5.7 \\
5.7\end{array}$ & $\begin{array}{l}8.7 \\
9.1 \\
8.2\end{array}$ & $\begin{array}{l}24.0 \\
25.0 \\
22.5\end{array}$ & $\begin{array}{l}13.7 \\
13.7 \\
13.6\end{array}$ \\
\hline $\begin{array}{l}M \times 3-7-A \\
M \times 3-7-B \\
M \times 3-7-C\end{array}$ & $\begin{array}{l}15.2 \\
14.2 \\
14.0\end{array}$ & $\begin{array}{l}5.6 \\
5.6 \\
5.6\end{array}$ & $\begin{array}{l}4.9 \\
4.9 \\
5.5\end{array}$ & $\begin{array}{l}13.5 \\
13.5 \\
15.0\end{array}$ & $\begin{array}{l}13.2 \\
13.3 \\
13.3\end{array}$ \\
\hline $\begin{array}{l}M X 3-8-A \\
M X 3-8-B \\
M X 3-8-C\end{array}$ & $\begin{array}{l}14.9 \\
14.6 \\
14.2\end{array}$ & $\begin{array}{l}5.6 \\
5.6 \\
5.6\end{array}$ & $\begin{array}{l}8.0 \\
6.7 \\
5.6\end{array}$ & $\begin{array}{l}22.0 \\
18.0 \\
15.5\end{array}$ & $\begin{array}{l}13.4 \\
13.4 \\
13.4\end{array}$ \\
\hline $\begin{array}{l}\text { MX3-9-A } \\
M X 3-9-B \\
M X 3-9 . C\end{array}$ & $\begin{array}{l}152 \\
14.2 \\
15.1\end{array}$ & $\begin{array}{l}5.7 \\
5.7 \\
5.7\end{array}$ & $\begin{array}{l}4.2 \\
2.7 \\
2.9\end{array}$ & $\begin{array}{l}11.5 \\
7.5 \\
8.0\end{array}$ & $\begin{array}{l}13.5 \\
13.5 \\
13.5\end{array}$ \\
\hline
\end{tabular}


Table D-5. Properties of fluid grouts prepared from Matrix 4

\begin{tabular}{cccccc}
\hline Run & $\begin{array}{c}\text { Critical } \\
\text { velocity } \\
\text { No. }\end{array}$ & $\begin{array}{c}\text { Frictional } \\
\text { pressure } \\
\text { drop } \\
\text { (gsi/min) }\end{array}$ & $\begin{array}{c}\text { Pump-head } \\
\text { pressure } \\
\text { (psi) }\end{array}$ & $\begin{array}{c}\text { 10-min gel } \\
\text { strength } \\
\left(\mathrm{lb}_{\mathrm{f}} / 100 \mathrm{ft}^{2}\right)\end{array}$ & $\begin{array}{c}\text { Density } \\
\text { (b/gal) }\end{array}$ \\
\hline MX4-1-A & 14.7 & 5.6 & 2.6 & 7.0 & 13.3 \\
MX4-1-B & 14.5 & 5.6 & 2.2 & 6.0 & 13.4 \\
MX4-1-C & 14.9 & 5.6 & 2.2 & 6.0 & 13.4 \\
MX4-2-A & 16.0 & 5.7 & 2.6 & 7.0 & 13.6 \\
MX4-2-B & 16.1 & 5.7 & 2.4 & 6.5 & 13.6 \\
MX4-2-C & 16.6 & 5.7 & 2.0 & 5.5 & 13.5 \\
MX4-3-A & 16.0 & 5.7 & 2.6 & 7.0 & 13.6 \\
MX4-3-B & 16.4 & 5.7 & 2.0 & 5.5 & 13.6 \\
MX4-3-C & 16.2 & 5.7 & 2.0 & 5.5 & 13.6 \\
MX4-4-A & 16.6 & 5.6 & 2.4 & 6.5 & 13.4 \\
MX4-4-B & 16.8 & 5.7 & 2.6 & 7.0 & 13.5 \\
MX4-4-C & 16.4 & 5.7 & 2.0 & 5.5 & 13.5 \\
MX4-5-A & 14.6 & 5.6 & 1.6 & 4.5 & 13.3 \\
MX4-5-B & 14.3 & 5.6 & 1.6 & 4.5 & 13.3 \\
MX4-5-C & 14.1 & 5.6 & 1.6 & 4.5 & 13.3 \\
MX4-6-A & 13.2 & 5.5 & 1.6 & 4.5 & 13.2 \\
MX4-6-B & 13.5 & 5.6 & 1.5 & 4.0 & 13.3 \\
MX4-6-C & 12.5 & 5.6 & 1.3 & 3.5 & 13.2 \\
MX4-7-A & 14.4 & 5.6 & 1.6 & 4.5 & 13.3 \\
MX4-7-B & 13.7 & 5.6 & 1.6 & 4.5 & 13.2 \\
MX4-7-C & 13.8 & 5.6 & 1.6 & 4.5 & 13.3 \\
MX4-8-A & 15.1 & 5.7 & 2.6 & 7.0 & 13.5 \\
MX4-8-B & 15.5 & 5.7 & 2.2 & 6.0 & 13.5 \\
MX4-8-C & 15.6 & 5.7 & 2.0 & 5.5 & 13.5 \\
MX4-9-A & 14.1 & 5.6 & 1.5 & 4.0 & 13.2 \\
MX4-9-B & 14.1 & 5.6 & 2.4 & 6.5 & 13.3 \\
MX4-9-C & 14.2 & 5.6 & 2.4 & 6.5 & 13.3 \\
\hline & & & & & \\
\hline
\end{tabular}


Table D-6. Properties of fluid grouts prepared from Matrix 5

\begin{tabular}{|c|c|c|c|c|c|}
\hline $\begin{array}{c}\text { Run } \\
\text { No. }\end{array}$ & $\begin{array}{c}\text { Critical } \\
\text { velocity } \\
\text { (gal/min) }\end{array}$ & $\begin{array}{l}\text { Frictional } \\
\text { pressure } \\
\text { drop } \\
(\mathrm{psi} / 100 \mathrm{ft})\end{array}$ & $\begin{array}{l}\text { Pump-head } \\
\text { pressure } \\
\text { (psi) }\end{array}$ & $\begin{array}{l}10-\text { min gel } \\
\text { strength } \\
\left(1 \mathrm{~b}_{\mathrm{f}} / 100 \mathrm{ft}^{2}\right)\end{array}$ & $\begin{array}{l}\text { Density } \\
\text { (lb/gal) }\end{array}$ \\
\hline $\begin{array}{l}\text { MX5-1-A } \\
\text { MX5-1-B } \\
M X 5-1-C\end{array}$ & $\begin{array}{l}16.8 \\
16.9 \\
16.8\end{array}$ & $\begin{array}{l}5.6 \\
5.6 \\
5.6\end{array}$ & $\begin{array}{l}2.4 \\
2.0 \\
1.8\end{array}$ & $\begin{array}{l}6.5 \\
5.5 \\
5.0\end{array}$ & $\begin{array}{l}13.4 \\
13.4 \\
13.4\end{array}$ \\
\hline $\begin{array}{l}\text { MX5-2-A } \\
\text { MX5-2-B } \\
\text { MX5-2-C }\end{array}$ & $\begin{array}{l}15.0 \\
14.2 \\
14.4\end{array}$ & $\begin{array}{l}5.5 \\
5.5 \\
5.5\end{array}$ & $\begin{array}{l}1.6 \\
1.6 \\
1.5\end{array}$ & $\begin{array}{l}4.5 \\
4.5 \\
4.0\end{array}$ & $\begin{array}{l}13.1 \\
13.1 \\
13.1\end{array}$ \\
\hline $\begin{array}{l}M X 5-3-A \\
M X 5-3-B \\
M X 5-3-C\end{array}$ & $\begin{array}{l}14.4 \\
14.5 \\
14.9\end{array}$ & $\begin{array}{l}5.5 \\
5.5 \\
5.5\end{array}$ & $\begin{array}{l}1.8 \\
1.8 \\
1.6\end{array}$ & $\begin{array}{l}5.0 \\
5.0 \\
4.5\end{array}$ & $\begin{array}{l}13.1 \\
13.1 \\
13.1\end{array}$ \\
\hline $\begin{array}{l}\text { MX5-4-A } \\
\text { MX5-4-B } \\
\text { MX5-4-C }\end{array}$ & $\begin{array}{l}14.9 \\
16.3 \\
16.5\end{array}$ & $\begin{array}{l}5.5 \\
5.5 \\
5.5\end{array}$ & $\begin{array}{l}1.3 \\
2.0 \\
1.6\end{array}$ & $\begin{array}{l}3.5 \\
5.5 \\
4.5\end{array}$ & $\begin{array}{l}13.2 \\
13.2 \\
13.1\end{array}$ \\
\hline $\begin{array}{l}\text { MX5-5-A } \\
\text { MX5-5-B } \\
\text { MX5-5-C }\end{array}$ & $\begin{array}{l}15.8 \\
16.0 \\
16.6\end{array}$ & $\begin{array}{l}5.6 \\
5.6 \\
5.6\end{array}$ & $\begin{array}{l}2.2 \\
2.0 \\
2.0\end{array}$ & $\begin{array}{l}6.0 \\
5.5 \\
5.5\end{array}$ & $\begin{array}{l}13.4 \\
13.4 \\
13.4\end{array}$ \\
\hline $\begin{array}{l}\text { MX5-6-A } \\
M X 5-6-B \\
M X 5-6-C\end{array}$ & $\begin{array}{l}16.5 \\
16.5 \\
17.1\end{array}$ & $\begin{array}{l}5.6 \\
5.6 \\
5.6\end{array}$ & $\begin{array}{l}2.0 \\
2.4 \\
2.4\end{array}$ & $\begin{array}{l}5.5 \\
6.5 \\
6.5\end{array}$ & $\begin{array}{l}13.4 \\
13.4 \\
13.4\end{array}$ \\
\hline $\begin{array}{l}\text { MX5-7-A } \\
\text { MX5-7-B } \\
\text { MX5-7-C }\end{array}$ & $\begin{array}{l}18.0 \\
17.3 \\
18.0\end{array}$ & $\begin{array}{l}5.6 \\
5.6 \\
5.6\end{array}$ & $\begin{array}{l}2.4 \\
2.6 \\
2.6\end{array}$ & $\begin{array}{l}6.5 \\
7.0 \\
7.0\end{array}$ & $\begin{array}{l}13.5 \\
13.4 \\
13.4\end{array}$ \\
\hline $\begin{array}{l}\text { MX5-8-A } \\
\text { MX5-8-B } \\
M \times 5-8-C\end{array}$ & $\begin{array}{l}16.3 \\
16.4 \\
16.0\end{array}$ & $\begin{array}{l}5.6 \\
5.6 \\
5.6\end{array}$ & $\begin{array}{l}2.2 \\
2.4 \\
2.6\end{array}$ & $\begin{array}{l}6.0 \\
6.5 \\
7.0\end{array}$ & $\begin{array}{l}13.4 \\
13.4 \\
13.4\end{array}$ \\
\hline $\begin{array}{l}\text { MX5-9-A } \\
\text { MX5-9-B } \\
\text { MX5-9-C }\end{array}$ & $\begin{array}{l}15.1 \\
14.8 \\
15.4 \\
\end{array}$ & $\begin{array}{l}5.6 \\
5.6 \\
5.6\end{array}$ & $\begin{array}{l}1.8 \\
1.8 \\
1.6\end{array}$ & $\begin{array}{l}5.0 \\
5.0 \\
4.5\end{array}$ & $\begin{array}{l}13.3 \\
13.3 \\
13.3\end{array}$ \\
\hline
\end{tabular}


Table D-7. Properties of fluid grouts prepared from Matrix 6

\begin{tabular}{cccccc}
\hline Run & $\begin{array}{c}\text { Critical } \\
\text { velocity } \\
\text { (gal/min) }\end{array}$ & $\begin{array}{c}\text { Frictional } \\
\text { pressure } \\
\text { drop } \\
\text { (psi/100 }\end{array}$ & $\begin{array}{c}\text { Pump-head } \\
\text { pressure } \\
\text { (psi) }\end{array}$ & $\begin{array}{c}\text { 10-min gel } \\
\text { strength } \\
\left(\text { lb }_{\text {f }} / 100 \mathrm{ft}^{2}\right)\end{array}$ & $\begin{array}{c}\text { Density } \\
\text { (lb/gal) }\end{array}$ \\
\hline MX6-1-A & 18.1 & 5.6 & 2.6 & 7.2 & 13.4 \\
MX6-1-B & 17.3 & 5.6 & 2.7 & 7.5 & 13.4 \\
MX6-1-C & 18.3 & 5.6 & 3.1 & 8.5 & 13.4 \\
MX6-2-A & 16.9 & 5.5 & 2.4 & 6.5 & 13.1 \\
MX6-2-B & 15.4 & 5.5 & 1.6 & 4.5 & 13.1 \\
MX6-2-C & 15.5 & 5.5 & 2.0 & 5.5 & 13.1 \\
MX6-3-A & 19.3 & 5.6 & 2.4 & 6.5 & 13.4 \\
MX6-3-B & 17.8 & 5.6 & 2.0 & 5.5 & 13.4 \\
MX6-3-C & 18.3 & 5.6 & 1.8 & 5.0 & 13.4 \\
MX6-4-A & 17.8 & 5.6 & 2.6 & 7.0 & 13.3 \\
MX6-4-B & 17.9 & 5.6 & 2.2 & 6.0 & 13.3 \\
MX6-4-C & 17.0 & 5.6 & 2.4 & 6.5 & 13.3 \\
MX6-5-A & 15.0 & 5.5 & 1.5 & 4.0 & 13.0 \\
MX6-5-B & 14.4 & 5.5 & 1.5 & 4.0 & 13.0 \\
MX6-5-C & 15.1 & 5.5 & 2.0 & 5.5 & 13.0 \\
MX6-6-A & 14.4 & 5.5 & 2.2 & 6.0 & 13.1 \\
MX6-6-B & 14.7 & 5.5 & 2.0 & 5.5 & 13.1 \\
MX6-6-C & 14.3 & 5.5 & 1.6 & 4.5 & 13.1 \\
MX6-7-A & 17.0 & 5.6 & 1.8 & 5.0 & 13.3 \\
MX6-7-B & 15.5 & 5.6 & 1.6 & 4.5 & 13.2 \\
MX6-7-C & 15.8 & 5.6 & 1.6 & 4.5 & 13.2 \\
MX6-8-A & 15.2 & 5.5 & 1.3 & 4.5 & 13.2 \\
MX6-8-B & 14.8 & 5.5 & 1.5 & 4.0 & 13.2 \\
MX6-8-C & 15.3 & 5.5 & 1.6 & 4.5 & 13.2 \\
MX6-9-A & 17.4 & 5.6 & 2.4 & 6.5 & 13.4 \\
MX6-9-B & 15.4 & 5.6 & 2.4 & 6.5 & 13.4 \\
MX6-9-C & 16.6 & 5.6 & 2.4 & 6.5 & 13.4 \\
\hline & & & & & \\
\hline
\end{tabular}


90

Table D-8. Properties of fluid grouts prepared from Matrix 7

\begin{tabular}{|c|c|c|c|c|c|}
\hline $\begin{array}{c}\text { Run } \\
\text { No. } \\
\end{array}$ & $\begin{array}{c}\text { Critical } \\
\text { velocity } \\
\text { (gal/min) }\end{array}$ & $\begin{array}{l}\text { Frictional } \\
\text { pressure } \\
\text { drop } \\
(\mathrm{psi} / 100 \mathrm{ft})\end{array}$ & $\begin{array}{l}\text { Pump-head } \\
\text { pressure } \\
\text { (psi) }\end{array}$ & $\begin{array}{l}10-\text { min gel } \\
\text { strength } \\
\left(1 b_{d} / 100 \mathrm{ft}^{2}\right)\end{array}$ & $\begin{array}{l}\text { Density } \\
\text { (lb/gal) }\end{array}$ \\
\hline $\begin{array}{l}\text { MX7-1-A } \\
M X 7-1-B \\
M X 7-1-C\end{array}$ & $\begin{array}{l}19.4 \\
17.4 \\
17.9\end{array}$ & $\begin{array}{l}5.7 \\
5.7 \\
5.6\end{array}$ & $\begin{array}{l}2.4 \\
2.6 \\
2.6\end{array}$ & $\begin{array}{l}6.5 \\
7.0 \\
7.0\end{array}$ & $\begin{array}{l}13.5 \\
13.5 \\
13.5\end{array}$ \\
\hline $\begin{array}{l}M X 7-2 \cdot A \\
M X 7-2 \cdot B \\
M X 7-2 \cdot C\end{array}$ & $\begin{array}{l}17.8 \\
18.4 \\
17.8\end{array}$ & $\begin{array}{l}5.7 \\
5.7 \\
5.7\end{array}$ & $\begin{array}{l}2.4 \\
2.6 \\
2.9\end{array}$ & $\begin{array}{l}6.5 \\
7.0 \\
8.0\end{array}$ & $\begin{array}{l}13.5 \\
13.5 \\
13.5\end{array}$ \\
\hline $\begin{array}{l}\text { MX7-3-A } \\
\text { MX7-3-B } \\
\text { MX7-3-C }\end{array}$ & $\begin{array}{l}18.0 \\
18.5 \\
18.0\end{array}$ & $\begin{array}{l}5.6 \\
5.6 \\
5.6\end{array}$ & $\begin{array}{l}2.0 \\
2.2 \\
1.8\end{array}$ & $\begin{array}{l}5.5 \\
6.0 \\
5.0\end{array}$ & $\begin{array}{l}13.4 \\
13.4 \\
13.3\end{array}$ \\
\hline $\begin{array}{l}M \times 7-4-A \\
M \times 7-4-B \\
M \times 7-4-C\end{array}$ & $\begin{array}{l}16.1 \\
15.2 \\
15.0\end{array}$ & $\begin{array}{l}5.5 \\
5.5 \\
5.5\end{array}$ & $\begin{array}{l}1.6 \\
1.6 \\
1.8\end{array}$ & $\begin{array}{l}4.5 \\
4.5 \\
5.0\end{array}$ & $\begin{array}{l}13.2 \\
13.2 \\
13.1\end{array}$ \\
\hline $\begin{array}{l}\text { MX7.5-A } \\
M X 7-5-B \\
M X 7.5-C\end{array}$ & $\begin{array}{l}16.3 \\
16.4 \\
16.4\end{array}$ & $\begin{array}{l}5.5 \\
5.5 \\
5.5\end{array}$ & $\begin{array}{l}2.0 \\
2.2 \\
1.8\end{array}$ & $\begin{array}{l}5.5 \\
6.0 \\
5.0\end{array}$ & $\begin{array}{l}13.2 \\
13.2 \\
13.2\end{array}$ \\
\hline $\begin{array}{l}M X 7-6-A \\
M X 7-6-B \\
M X 7-6-C\end{array}$ & $\begin{array}{l}18.8 \\
18.8 \\
17.3\end{array}$ & $\begin{array}{l}5.6 \\
5.6 \\
5.7\end{array}$ & $\begin{array}{l}2.4 \\
2.4 \\
2.4\end{array}$ & $\begin{array}{l}6.5 \\
6.5 \\
6.5\end{array}$ & $\begin{array}{l}13.5 \\
13.5 \\
13.5\end{array}$ \\
\hline $\begin{array}{l}M \times 7-7 . A \\
M X 7-7 . B \\
M X 7.7-C\end{array}$ & $\begin{array}{l}16.3 \\
16.1 \\
16.5\end{array}$ & $\begin{array}{l}5.6 \\
5.6 \\
5.6\end{array}$ & $\begin{array}{l}1.8 \\
1.6 \\
1.8\end{array}$ & $\begin{array}{l}5.0 \\
4.5 \\
5.0\end{array}$ & $\begin{array}{l}13.3 \\
13.3 \\
13.2\end{array}$ \\
\hline $\begin{array}{l}M X 7-8-A \\
M X 7-8-B \\
M X 7-8-C\end{array}$ & $\begin{array}{l}17.6 \\
18.4 \\
17.4\end{array}$ & $\begin{array}{l}5.7 \\
5.7 \\
5.7\end{array}$ & $\begin{array}{l}2.4 \\
2.6 \\
2.6\end{array}$ & $\begin{array}{l}6.5 \\
7.0 \\
7.0\end{array}$ & $\begin{array}{l}13.5 \\
13.5 \\
13.5\end{array}$ \\
\hline $\begin{array}{l}\text { MX7-9.A } \\
\text { MX7-9.B } \\
\text { MX7-9-C }\end{array}$ & $\begin{array}{l}16.0 \\
14.8 \\
14.8 \\
\end{array}$ & $\begin{array}{l}5.6 \\
5.6 \\
5.6 \\
\end{array}$ & $\begin{array}{l}2.0 \\
1.8 \\
2.2\end{array}$ & $\begin{array}{l}5.5 \\
5.0 \\
6.0\end{array}$ & $\begin{array}{l}13.3 \\
13.3 \\
13.3\end{array}$ \\
\hline
\end{tabular}


Table D.9. Properties of fluid grouts prepared from Matrix 8

\begin{tabular}{|c|c|c|c|c|c|}
\hline $\begin{array}{c}\text { Run } \\
\text { No. } \\
\end{array}$ & $\begin{array}{c}\text { Critica! } \\
\text { velocity } \\
\text { (gal/min) }\end{array}$ & $\begin{array}{l}\text { Frictional } \\
\text { pressure } \\
\text { drop } \\
(\mathrm{psi} / 100 \mathrm{ft}) \\
\end{array}$ & $\begin{array}{l}\text { Pump-head } \\
\text { pressure } \\
\text { (psi) }\end{array}$ & $\begin{array}{l}\text { 10-min gel } \\
\text { strength } \\
\left(1 b_{f} / 100 \mathrm{ft}^{2}\right)\end{array}$ & $\begin{array}{l}\text { Density } \\
\text { (lb/gal) }\end{array}$ \\
\hline $\begin{array}{l}\text { MX8-1-A } \\
\text { MX8-1-B } \\
\text { MX8-1-C }\end{array}$ & $\begin{array}{l}16.3 \\
16.8 \\
17.0\end{array}$ & $\begin{array}{l}5.6 \\
5.6 \\
5.6\end{array}$ & $\begin{array}{l}2.4 \\
2.4 \\
2.2\end{array}$ & $\begin{array}{l}6.5 \\
6.5 \\
6.0\end{array}$ & $\begin{array}{l}13.4 \\
13.4 \\
13.4\end{array}$ \\
\hline $\begin{array}{l}M X 8-2-A \\
M X 8-2-B \\
M X 8-2-C\end{array}$ & $\begin{array}{l}16.8 \\
14.7 \\
16.6\end{array}$ & $\begin{array}{l}5.5 \\
5.5 \\
5.5\end{array}$ & $\begin{array}{l}1.8 \\
1.8 \\
1.6\end{array}$ & $\begin{array}{l}5.0 \\
5.0 \\
4.5\end{array}$ & $\begin{array}{l}13.1 \\
13.2 \\
13.1\end{array}$ \\
\hline $\begin{array}{l}\text { MX8-3-A } \\
M X 8-3-B \\
M \times 8-3-C\end{array}$ & $\begin{array}{l}17.6 \\
17.3 \\
16.9\end{array}$ & $\begin{array}{l}5.6 \\
5.6 \\
5.6\end{array}$ & $\begin{array}{l}1.8 \\
1.8 \\
1.8\end{array}$ & $\begin{array}{l}5.0 \\
5.0 \\
5.0\end{array}$ & $\begin{array}{l}13.4 \\
13.4 \\
13.4\end{array}$ \\
\hline $\begin{array}{l}M \times 8.4-A \\
M \times 8-4-B \\
M \times 8-4 . C\end{array}$ & $\begin{array}{l}16.9 \\
16.8 \\
16.0\end{array}$ & $\begin{array}{l}5.6 \\
5.6 \\
5.6\end{array}$ & $\begin{array}{l}1.6 \\
1.5 \\
1.6\end{array}$ & $\begin{array}{l}4.5 \\
4.0 \\
4.5\end{array}$ & $\begin{array}{l}13.3 \\
13.3 \\
13.3\end{array}$ \\
\hline $\begin{array}{l}\text { MX8-5-A } \\
M X 8-5 . B \\
M X 8-5 . C\end{array}$ & $\begin{array}{l}16.2 \\
15.4 \\
15.4\end{array}$ & $\begin{array}{l}5.5 \\
5.5 \\
5.5\end{array}$ & $\begin{array}{l}1.6 \\
1.6 \\
1.8\end{array}$ & $\begin{array}{l}4.5 \\
4.5 \\
5.0\end{array}$ & $\begin{array}{l}13.2 \\
13.2 \\
13.2\end{array}$ \\
\hline $\begin{array}{l}M \times 8-6-A \\
M X 8-6-B \\
M X 8-6-C\end{array}$ & $\begin{array}{l}14.7 \\
15.0 \\
14.8\end{array}$ & $\begin{array}{l}5.5 \\
5.5 \\
5.5\end{array}$ & $\begin{array}{l}1.5 \\
1.1 \\
1.5\end{array}$ & $\begin{array}{l}4.0 \\
3.0 \\
4.0\end{array}$ & $\begin{array}{l}13.1 \\
13.1 \\
13.1\end{array}$ \\
\hline $\begin{array}{l}M \times 8.7-A \\
M \times 8-7 . B \\
M X 8-7-C\end{array}$ & $\begin{array}{l}16.4 \\
16.1 \\
15.9\end{array}$ & $\begin{array}{l}5.5 \\
5.5 \\
5.5\end{array}$ & $\begin{array}{l}1.8 \\
1.8 \\
1.8\end{array}$ & $\begin{array}{l}5.0 \\
5.0 \\
5.0\end{array}$ & $\begin{array}{l}13.2 \\
13.2 \\
13.2\end{array}$ \\
\hline $\begin{array}{l}\text { MX8-8-A } \\
\text { MX8-8-B } \\
M X 8-8-C\end{array}$ & $\begin{array}{l}16.2 \\
17.2 \\
17.8\end{array}$ & $\begin{array}{l}5.6 \\
5.6 \\
5.6\end{array}$ & $\begin{array}{l}2.6 \\
2.6 \\
2.4\end{array}$ & $\begin{array}{l}7.0 \\
7.0 \\
6.5\end{array}$ & $\begin{array}{l}13.5 \\
13.4 \\
13.5\end{array}$ \\
\hline $\begin{array}{l}\text { MX8-9-A } \\
\text { MX8-9-B } \\
\text { MX8-9-C }\end{array}$ & $\begin{array}{l}18.0 \\
17.4 \\
17.2\end{array}$ & $\begin{array}{l}5.7 \\
5.7 \\
5.7\end{array}$ & $\begin{array}{l}2.4 \\
9.1 \\
2.4\end{array}$ & $\begin{array}{r}6.5 \\
25.0 \\
6.5\end{array}$ & $\begin{array}{l}13.5 \\
13.5 \\
13.5\end{array}$ \\
\hline
\end{tabular}


Table D.10. Properties of fluld grouts prepared from Matrix 9

\begin{tabular}{|c|c|c|c|c|c|}
\hline $\begin{array}{c}\text { Run } \\
\text { No. } \\
\end{array}$ & $\begin{array}{c}\text { Critical } \\
\text { velocity } \\
\text { (gal/min) }\end{array}$ & $\begin{array}{c}\text { Frictional } \\
\text { pressure } \\
\text { drop } \\
(\mathrm{ps} / 100 \mathrm{ft}) \\
\end{array}$ & $\begin{array}{c}\text { Pump-head } \\
\text { pressure } \\
\text { (psi) }\end{array}$ & $\begin{array}{c}\text { 10-min gel } \\
\text { strength } \\
\left(1 \mathrm{~b}, 100 \mathrm{ft}^{2}\right) \\
\end{array}$ & $\begin{array}{l}\text { Density } \\
\text { (lb/gal) }\end{array}$ \\
\hline $\begin{array}{l}\text { MX9.1.A } \\
M \times 9.1 . B \\
M X 9.1 . C\end{array}$ & $\begin{array}{l}17.2 \\
16.5 \\
16.7\end{array}$ & $\begin{array}{l}5.6 \\
5.6 \\
5.6\end{array}$ & $\begin{array}{l}1.5 \\
1.3 \\
1.8\end{array}$ & $\begin{array}{l}4.0 \\
3.5 \\
5.0\end{array}$ & $\begin{array}{l}13.4 \\
13.4 \\
13.4\end{array}$ \\
\hline $\begin{array}{l}M \times 9.2 . A \\
M \times 9.2-B \\
M \times 9.2 . C\end{array}$ & $\begin{array}{l}14.9 \\
15.0 \\
14.9\end{array}$ & $\begin{array}{l}5.5 \\
5.5 \\
5.5\end{array}$ & $\begin{array}{l}1.6 \\
1.5 \\
1.6\end{array}$ & $\begin{array}{l}4.5 \\
4.0 \\
4.5\end{array}$ & $\begin{array}{l}13.1 \\
13.1 \\
13.1\end{array}$ \\
\hline $\begin{array}{l}\text { MX9.3.A } \\
\text { MX9.3.B } \\
\text { MX9.3.C }\end{array}$ & $\begin{array}{l}14.7 \\
13.8 \\
14.5\end{array}$ & $\begin{array}{l}5.5 \\
5.5 \\
5.5\end{array}$ & $\begin{array}{l}1.3 \\
1.1 \\
1.1\end{array}$ & $\begin{array}{l}3.5 \\
3.0 \\
3.0\end{array}$ & $\begin{array}{l}13.1 \\
13.1 \\
13.1\end{array}$ \\
\hline $\begin{array}{l}M X 9.4 . A \\
M X 9.4 . B \\
M X 9.4 . C\end{array}$ & $\begin{array}{l}15.7 \\
16.7 \\
15.9\end{array}$ & $\begin{array}{l}5.6 \\
5.6 \\
5.6\end{array}$ & $\begin{array}{l}1.8 \\
2.0 \\
1.8\end{array}$ & $\begin{array}{l}5.0 \\
5.5 \\
5.0\end{array}$ & $\begin{array}{l}13.5 \\
13.5 \\
13.5\end{array}$ \\
\hline $\begin{array}{l}\text { MX9.5.A } \\
M \times 9.5 . B \\
M \times 9.5 . C\end{array}$ & $\begin{array}{l}15.3 \\
14.7 \\
14.3\end{array}$ & $\begin{array}{l}5.6 \\
5.6 \\
5.6\end{array}$ & $\begin{array}{l}1.5 \\
1.6 \\
1.5\end{array}$ & $\begin{array}{l}4.0 \\
4.5 \\
4.0\end{array}$ & $\begin{array}{l}13.3 \\
13.3 \\
13.3\end{array}$ \\
\hline $\begin{array}{l}\text { MX9-6.A } \\
\text { MX9.6-B } \\
M X 9.6 . C\end{array}$ & $\begin{array}{l}15.1 \\
15.9 \\
14.7\end{array}$ & $\begin{array}{l}5.5 \\
5.5 \\
5.5\end{array}$ & $\begin{array}{l}1.6 \\
1.6 \\
1.5\end{array}$ & $\begin{array}{l}4.5 \\
4.5 \\
4.0\end{array}$ & $\begin{array}{l}13.1 \\
13.1 \\
13.2\end{array}$ \\
\hline $\begin{array}{l}\text { MX9.7-A } \\
M X 9.7 . B \\
M X 9.7-C\end{array}$ & $\begin{array}{l}17.5 \\
16.0 \\
18.5\end{array}$ & $\begin{array}{l}5.6 \\
5.6 \\
5.6\end{array}$ & $\begin{array}{l}2.2 \\
2.0 \\
2.0\end{array}$ & $\begin{array}{l}6.0 \\
5.5 \\
5.5\end{array}$ & $\begin{array}{l}13.5 \\
13.4 \\
13.5\end{array}$ \\
\hline $\begin{array}{l}\text { MX9.8-A } \\
\text { MX9-8-B } \\
\text { MX9.8-C }\end{array}$ & $\begin{array}{l}15.5 \\
15.4 \\
15.2\end{array}$ & $\begin{array}{l}5.5 \\
5.5 \\
5.6\end{array}$ & $\begin{array}{l}1.8 \\
1.5 \\
1.5\end{array}$ & $\begin{array}{l}5.0 \\
4.0 \\
4.0\end{array}$ & $\begin{array}{l}13.2 \\
13.2 \\
13.2\end{array}$ \\
\hline $\begin{array}{l}\text { MX9.9.A } \\
\text { MX9.9.B } \\
\text { MX9.9.C }\end{array}$ & $\begin{array}{l}18.0 \\
17.4 \\
17.6 \\
\end{array}$ & $\begin{array}{l}5.6 \\
5.6 \\
5.6 \\
\end{array}$ & $\begin{array}{l}1.8 \\
2.4 \\
2.2 \\
\end{array}$ & $\begin{array}{l}5.0 \\
6.5 \\
6.0 \\
\end{array}$ & $\begin{array}{l}13.4 \\
13.4 \\
13.4 \\
\end{array}$ \\
\hline
\end{tabular}


Table D.11. Properties of fluid grouts prepared from Matrix 10

\begin{tabular}{|c|c|c|c|c|c|}
\hline $\begin{array}{c}\text { Run } \\
\text { No. }\end{array}$ & $\begin{array}{c}\text { Critical } \\
\text { velocity } \\
\text { (gal/min) }\end{array}$ & $\begin{array}{c}\text { Frictional } \\
\text { pressure } \\
\text { drop } \\
(\mathrm{psi} / 100 \mathrm{ft}) \\
\end{array}$ & $\begin{array}{c}\text { Pump-head } \\
\text { pressure } \\
\text { (psi) }\end{array}$ & $\begin{array}{l}\text { 10-min gel } \\
\text { strength } \\
\left(16 / 100 \mathrm{ft}^{2}\right)\end{array}$ & $\begin{array}{l}\text { Density } \\
\text { (lb/gal) }\end{array}$ \\
\hline $\begin{array}{l}\mathrm{MX10-1-A} \\
\mathrm{MX10-1 \cdot B} \\
\mathrm{MX} 10-1 \cdot \mathrm{C}\end{array}$ & $\begin{array}{l}15.8 \\
15.4 \\
14.3\end{array}$ & $\begin{array}{l}5.5 \\
5.5 \\
5.5\end{array}$ & $\begin{array}{l}1.3 \\
1.5 \\
1.1\end{array}$ & $\begin{array}{l}3.5 \\
4.0 \\
3.0\end{array}$ & $\begin{array}{l}13.2 \\
13.2 \\
13.1\end{array}$ \\
\hline $\begin{array}{l}M X 10-2 \cdot A \\
M X 10-2 \cdot B \\
M X 10-2 \cdot C\end{array}$ & $\begin{array}{l}17.4 \\
16.8 \\
16.8\end{array}$ & $\begin{array}{l}5.6 \\
5.6 \\
5.6\end{array}$ & $\begin{array}{l}1.6 \\
1.8 \\
1.6\end{array}$ & $\begin{array}{l}4.5 \\
5.0 \\
4.5\end{array}$ & $\begin{array}{l}13.3 \\
13.3 \\
13.3\end{array}$ \\
\hline $\begin{array}{l}\mathrm{MX10-3-A} \\
\mathrm{MX10-3 \cdot B} \\
\mathrm{MX10-3.C}\end{array}$ & $\begin{array}{l}16.8 \\
15.8 \\
16.3\end{array}$ & $\begin{array}{l}5.6 \\
5.6 \\
5.6\end{array}$ & $\begin{array}{l}1.6 \\
1.6 \\
1.5\end{array}$ & $\begin{array}{l}4.5 \\
4.5 \\
4.0\end{array}$ & $\begin{array}{l}13.3 \\
13.3 \\
13.3\end{array}$ \\
\hline $\begin{array}{l}M \times 10-4-A \\
M \times 10-4-B \\
M \times 10-4-C\end{array}$ & $\begin{array}{l}16.6 \\
16.2 \\
16.8\end{array}$ & $\begin{array}{l}5.6 \\
5.6 \\
5.6\end{array}$ & $\begin{array}{l}1.3 \\
1.6 \\
1.5\end{array}$ & $\begin{array}{l}3.5 \\
4.5 \\
4.0\end{array}$ & $\begin{array}{l}13.3 \\
13.3 \\
13.3\end{array}$ \\
\hline $\begin{array}{l}\text { MX10-5-A } \\
\text { MX10-5-B } \\
\text { MX10-5.C }\end{array}$ & $\begin{array}{l}14.4 \\
15.1 \\
14.5\end{array}$ & $\begin{array}{l}5.5 \\
5.5 \\
5.5\end{array}$ & $\begin{array}{l}1.3 \\
1.5 \\
1.3\end{array}$ & $\begin{array}{l}3.5 \\
4.0 \\
3.5\end{array}$ & $\begin{array}{l}13.1 \\
13.1 \\
13.1\end{array}$ \\
\hline $\begin{array}{l}M \times 10-6 \cdot A \\
M X 10-6-B \\
M X 10-6-C\end{array}$ & $\begin{array}{l}14.1 \\
13.6 \\
14.5\end{array}$ & $\begin{array}{l}5.5 \\
5.5 \\
5.5\end{array}$ & $\begin{array}{l}1.3 \\
1.3 \\
1.3\end{array}$ & $\begin{array}{l}3.5 \\
3.5 \\
3.5\end{array}$ & $\begin{array}{l}13.1 \\
13.0 \\
13.0\end{array}$ \\
\hline $\begin{array}{l}\mathrm{MX10-7.A} \\
\mathrm{MX10-7.B} \\
\mathrm{MX10-7.C}\end{array}$ & $\begin{array}{l}14.8 \\
14.9 \\
14.1\end{array}$ & $\begin{array}{l}5.5 \\
5.5 \\
5.5\end{array}$ & $\begin{array}{l}1.3 \\
1.3 \\
1.5\end{array}$ & $\begin{array}{l}3.5 \\
3.5 \\
4.0\end{array}$ & $\begin{array}{l}13.1 \\
13.1 \\
13.1\end{array}$ \\
\hline $\begin{array}{l}\text { MX10-8.A } \\
\text { MX10-8.B } \\
M \times 10-8 . C\end{array}$ & $\begin{array}{l}15.9 \\
15.6 \\
15.0\end{array}$ & $\begin{array}{l}5.6 \\
5.6 \\
5.6\end{array}$ & $\begin{array}{l}1.5 \\
1.5 \\
1.6\end{array}$ & $\begin{array}{l}4.0 \\
4.0 \\
4.5\end{array}$ & $\begin{array}{l}13.3 \\
13.3 \\
13.3\end{array}$ \\
\hline $\begin{array}{l}\text { MX10-9.A } \\
\text { MX10-9.B } \\
\text { MX10-9.C }\end{array}$ & $\begin{array}{l}14.3 \\
14.8 \\
14.9\end{array}$ & $\begin{array}{l}5.5 \\
5.5 \\
5.5\end{array}$ & $\begin{array}{l}1.3 \\
1.3 \\
1.3\end{array}$ & $\begin{array}{l}3.5 \\
3.5 \\
3.5\end{array}$ & $\begin{array}{l}13.1 \\
13.1 \\
13.1\end{array}$ \\
\hline
\end{tabular}


Table D-12. Properties of nuld grouts prepared from Matrix 11

\begin{tabular}{|c|c|c|c|c|c|}
\hline $\begin{array}{l}\text { Run } \\
\text { No. }\end{array}$ & $\begin{array}{l}\text { Critical } \\
\text { velocity } \\
\text { (gal/min) }\end{array}$ & $\begin{array}{l}\text { Frictional } \\
\text { pressure } \\
\text { drop } \\
\text { (psi/100 } \mathrm{t})\end{array}$ & $\begin{array}{c}\text { Pump-head } \\
\text { pressure } \\
\text { (psi) }\end{array}$ & $\begin{array}{l}\text { 10-min gel } \\
\text { strength } \\
\left(1 b_{f} / 100 \mathrm{f}^{2}\right)\end{array}$ & $\begin{array}{l}\text { Density } \\
\text { (lb/gal) }\end{array}$ \\
\hline $\begin{array}{l}\mathrm{MX} 11.1 . \mathrm{A} \\
\mathrm{MX} 11.1 . \mathrm{B} \\
\mathrm{MX} 11.1 . \mathrm{C}\end{array}$ & $\begin{array}{l}15.3 \\
15.3 \\
14.6\end{array}$ & $\begin{array}{l}5.5 \\
5.5 \\
5.5\end{array}$ & $\begin{array}{l}1.5 \\
1.6 \\
1.5\end{array}$ & $\begin{array}{l}4.0 \\
4.5 \\
4.0\end{array}$ & $\begin{array}{l}13.2 \\
13.2 \\
13.2\end{array}$ \\
\hline $\begin{array}{l}M X 11.2 . A \\
M X 11.2 . B \\
M X 11.2-C\end{array}$ & $\begin{array}{l}15.8 \\
15.0 \\
15.6\end{array}$ & $\begin{array}{l}5.6 \\
5.6 \\
5.6\end{array}$ & $\begin{array}{l}1.8 \\
2.0 \\
2.2\end{array}$ & $\begin{array}{l}5.0 \\
5.5 \\
6.0\end{array}$ & $\begin{array}{l}13.4 \\
13.4 \\
13.4\end{array}$ \\
\hline $\begin{array}{l}M X 11.3-A \\
M X 11.3-B \\
M X 11.3 . C\end{array}$ & $\begin{array}{l}15.3 \\
15.6 \\
14.9\end{array}$ & $\begin{array}{l}5.6 \\
5.6 \\
5.6\end{array}$ & $\begin{array}{l}1.6 \\
1.6 \\
2.0\end{array}$ & $\begin{array}{l}4.5 \\
4.5 \\
5.5\end{array}$ & $\begin{array}{l}13.4 \\
13.4 \\
13.4\end{array}$ \\
\hline $\begin{array}{l}M X 11.4-A \\
M X 11.4-B \\
M X 11 \cdot 4-C\end{array}$ & $\begin{array}{l}16.3 \\
15.4 \\
16.6\end{array}$ & $\begin{array}{l}5.6 \\
5.6 \\
5.6\end{array}$ & $\begin{array}{l}1.8 \\
1.8 \\
1.4\end{array}$ & $\begin{array}{l}5.0 \\
5.0 \\
4.0\end{array}$ & $\begin{array}{l}13.4 \\
13.4 \\
13.5\end{array}$ \\
\hline $\begin{array}{l}M X 11.5-A \\
M X 11.5-B \\
M X 11.5-C\end{array}$ & $\begin{array}{l}14.9 \\
14.8 \\
13.3\end{array}$ & $\begin{array}{l}5.5 \\
5.5 \\
5.5\end{array}$ & $\begin{array}{l}1.3 \\
1.3 \\
1.3\end{array}$ & $\begin{array}{l}3.5 \\
3.5 \\
3.5\end{array}$ & $\begin{array}{l}13.0 \\
13.0 \\
13.0\end{array}$ \\
\hline $\begin{array}{l}M X 11-6-A \\
M X 11-6-B \\
M X 11-6-C\end{array}$ & $\begin{array}{l}14.4 \\
14.2 \\
13.6\end{array}$ & $\begin{array}{l}5.5 \\
5.5 \\
5.5\end{array}$ & $\begin{array}{l}1.3 \\
1.1 \\
1.5\end{array}$ & $\begin{array}{l}3.5 \\
3.0 \\
4.0\end{array}$ & $\begin{array}{l}13.0 \\
13.0 \\
13.0\end{array}$ \\
\hline $\begin{array}{l}M X 11.7 . A \\
M X 11.7 . B \\
M X 11.7 . C\end{array}$ & $\begin{array}{l}15.8 \\
15.7 \\
15.6\end{array}$ & $\begin{array}{l}5.6 \\
5.6 \\
5.6\end{array}$ & $\begin{array}{l}1.6 \\
1.5 \\
1.8\end{array}$ & $\begin{array}{l}4.5 \\
4.0 \\
5.0\end{array}$ & $\begin{array}{l}13.3 \\
13.3 \\
13.3\end{array}$ \\
\hline $\begin{array}{l}M X 11.8-A \\
M X 11.8-B \\
M X 11.8-C\end{array}$ & $\begin{array}{l}15.0 \\
14.0 \\
14.1\end{array}$ & $\begin{array}{l}5.5 \\
5.5 \\
5.5\end{array}$ & $\begin{array}{l}1.3 \\
1.5 \\
1.5\end{array}$ & $\begin{array}{l}3.5 \\
4.0 \\
4.0\end{array}$ & $\begin{array}{l}13.1 \\
13.1 \\
13.1\end{array}$ \\
\hline $\begin{array}{l}M X 11.9 . A \\
M X 11.9-B \\
M X 11.9 . C\end{array}$ & $\begin{array}{l}14.6 \\
14.9 \\
14.8 \\
\end{array}$ & $\begin{array}{l}5.5 \\
5.5 \\
5.5\end{array}$ & $\begin{array}{l}1.3 \\
1.5 \\
1.5\end{array}$ & $\begin{array}{l}3.5 \\
4.0 \\
4.0\end{array}$ & $\begin{array}{l}13.1 \\
13.1 \\
13.1 \\
\end{array}$ \\
\hline
\end{tabular}


Table D.13. Properiles of fluid grouts prepared from Matrix 12

\begin{tabular}{|c|c|c|c|c|c|}
\hline $\begin{array}{l}\text { Run } \\
\text { No. }\end{array}$ & $\begin{array}{c}\text { Critical } \\
\text { velocity } \\
\left(\mathrm{g}^{2} / \mathrm{m} / \mathrm{n}\right)\end{array}$ & $\begin{array}{l}\text { Frictional } \\
\text { pressure } \\
\text { drop } \\
(\mathrm{psi} / 100 \mathrm{ft}) \\
\end{array}$ & $\begin{array}{c}\text { Pump-head } \\
\text { pressure } \\
(\mathrm{psi})\end{array}$ & $\begin{array}{l}\text { 10-min gel } \\
\text { strengih } \\
\left(1 \mathrm{~b} / 100 \mathrm{ft}^{2}\right)\end{array}$ & $\begin{array}{l}\text { Density } \\
\text { (lb/gal) }\end{array}$ \\
\hline $\begin{array}{l}M \times 12 \cdot 1 \cdot A \\
M X 12-1 \cdot B \\
M X 12 \cdot 1 \cdot C\end{array}$ & $\begin{array}{l}16.4 \\
15.2 \\
16.1\end{array}$ & $\begin{array}{l}5.6 \\
5.6 \\
5.6\end{array}$ & $\begin{array}{l}2.7 \\
3.1 \\
2.9\end{array}$ & $\begin{array}{l}7.5 \\
8.5 \\
8.0\end{array}$ & $\begin{array}{l}13.3 \\
13.3 \\
13.3\end{array}$ \\
\hline 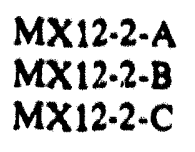 & $\begin{array}{l}14.8 \\
13.9 \\
14.4\end{array}$ & $\begin{array}{l}5.5 \\
5.5 \\
5.5\end{array}$ & $\begin{array}{l}1.6 \\
2.0 \\
2.0\end{array}$ & $\begin{array}{l}4.5 \\
5.5 \\
5.5\end{array}$ & $\begin{array}{l}13.0 \\
13.0 \\
13.0\end{array}$ \\
\hline $\begin{array}{l}M \times 12.3-A \\
M X 12-3-B \\
M X 12-3-C\end{array}$ & $\begin{array}{l}14.6 \\
14.1 \\
13.3\end{array}$ & $\begin{array}{l}5.4 \\
5.4 \\
5.4\end{array}$ & $\begin{array}{l}1.6 \\
1.8 \\
1.8\end{array}$ & $\begin{array}{l}4.5 \\
5.0 \\
5.0\end{array}$ & $\begin{array}{l}12.9 \\
13.0 \\
12.9\end{array}$ \\
\hline $\begin{array}{l}M X 12.4-A \\
M X 12.4-B \\
M X 12.4 . C\end{array}$ & $\begin{array}{l}15.8 \\
15.4 \\
15.8\end{array}$ & $\begin{array}{l}5.5 \\
5.5 \\
5.5\end{array}$ & $\begin{array}{l}2.0 \\
2.2 \\
2.2\end{array}$ & $\begin{array}{l}5.5 \\
6.0 \\
6.0\end{array}$ & $\begin{array}{l}13.1 \\
13.1 \\
13.1\end{array}$ \\
\hline $\begin{array}{l}M X 12.5 \cdot A \\
M X 12.5-B \\
M X 12.5 . C\end{array}$ & $\begin{array}{l}16.2 \\
16.3 \\
16.0\end{array}$ & $\begin{array}{l}5.5 \\
5.5 \\
5.5\end{array}$ & $\begin{array}{l}3.1 \\
2.6 \\
2.9\end{array}$ & $\begin{array}{l}8.5 \\
7.0 \\
8.0\end{array}$ & $\begin{array}{l}13.2 \\
13.2 \\
13.2\end{array}$ \\
\hline $\begin{array}{l}\mathrm{MX12}-6 \cdot \mathrm{A} \\
\mathrm{MX12} \cdot 6-\mathrm{B} \\
\mathrm{MX12-6-C}\end{array}$ & $\begin{array}{l}17.6 \\
17.1 \\
17.9\end{array}$ & $\begin{array}{l}5.6 \\
5.6 \\
5.6\end{array}$ & $\begin{array}{l}3.6 \\
3.6 \\
3.1\end{array}$ & $\begin{array}{c}10.0 \\
10.0 \\
8.5\end{array}$ & $\begin{array}{l}13.3 \\
13.3 \\
13.3\end{array}$ \\
\hline $\begin{array}{l}M X 12-7 \cdot A \\
M X 12-7-B \\
M X 12-7 \cdot C\end{array}$ & $\begin{array}{l}16.6 \\
16.8 \\
16.5\end{array}$ & $\begin{array}{l}5.6 \\
5.6 \\
5.6\end{array}$ & $\begin{array}{l}3.3 \\
3.5 \\
3.1\end{array}$ & $\begin{array}{l}9.0 \\
9.5 \\
8.5\end{array}$ & $\begin{array}{l}13.3 \\
13.3\end{array}$ \\
\hline $\begin{array}{l}\mathrm{MX12-8-A} \\
\mathrm{MX12-8- \textrm {B }} \\
\mathrm{MX12-8- \textrm {C }}\end{array}$ & $\begin{array}{l}15.5 \\
15.1 \\
15.3\end{array}$ & $\begin{array}{l}5.5 \\
5.5 \\
5.5\end{array}$ & $\begin{array}{l}2.4 \\
2.2 \\
2.4\end{array}$ & $\begin{array}{l}6.5 \\
6.0 \\
6.5\end{array}$ & $\begin{array}{l}13.1 \\
13.1 \\
13.1\end{array}$ \\
\hline $\begin{array}{l}M X 12.9 . A \\
M X 12.9-B \\
M X 12.9 . C\end{array}$ & $\begin{array}{l}15.6 \\
15.7 \\
16.2\end{array}$ & $\begin{array}{l}5.5 \\
5.5 \\
5.5\end{array}$ & $\begin{array}{l}2.6 \\
2.4 \\
2.2\end{array}$ & $\begin{array}{l}7.0 \\
6.5 \\
6.0\end{array}$ & $\begin{array}{l}13.1 \\
13.0 \\
13.0\end{array}$ \\
\hline
\end{tabular}


Appendix E. DRAINABLE-WATER DATA FOR ALL EXPERIMENTAL RUNS 
99

Table E-1. Drainable-water values for grouts prepared from Matrix 1

\begin{tabular}{|c|c|c|c|c|c|c|c|}
\hline \multirow{2}{*}{$\begin{array}{r}\text { Run } \\
\text { No. }\end{array}$} & \multirow{2}{*}{$\begin{array}{c}\text { Corresponding } \\
\text { observation } \\
\text { No. }\end{array}$} & \multicolumn{6}{|c|}{ Drainable water $(\mathrm{mL})$ observed at } \\
\hline & & $2 \mathrm{~h}$ & $1 \mathrm{~d}$ & $7 d$ & $14 \mathrm{~d}$ & $21 \mathrm{~d}$ & $28 \mathrm{~d}$ \\
\hline$M X 1-1-A$ & 5 & 11 & 12 & 10 & 8 & 8 & 8 \\
\hline$M X 1-^{-}-B$ & & 17 & 20 & 16 & 16 & 16 & 15 \\
\hline $\mathrm{MX} 1-1-\mathrm{C}$ & & 12 & 14 & 10 & 10 & 10 & 10 \\
\hline MX1-2-A & 2 & 12 & 14 & 11 & 10 & 10 & 10 \\
\hline MX1-2-B & & 9 & 10 & 6 & 7 & 6 & 6 \\
\hline$M X 1-2-C$ & & 7 & 8 & 4 & 6 & 4 & 3 \\
\hline MX1-3-A & 4 & 14 & 14 & 14 & 10 & 10 & 10 \\
\hline MX1-3-B & & 13 & 13 & 11 & 10 & 10 & 7 \\
\hline MX1-3-C & & 14 & 15 & 13 & 10 & 10 & 8 \\
\hline MX1-4-A & 3 & 12 & 12 & 12 & 8 & 7 & 8 \\
\hline MX1-4-B & & 10 & 9 & 8 & 6 & 5 & 5 \\
\hline$M X 1-4-C$ & & 11 & 10 & 6 & 6 & 6 & 5 \\
\hline MX1-5-A & 7 & 18 & 18 & 16 & 14 & 14 & 14 \\
\hline MX1-5-B & & 17 & 17 & 15 & 14 & 14 & 14 \\
\hline$M X 1-5-C$ & & 18 & 18 & 18 & 16 & 14 & 15 \\
\hline MX1-6-A & 8 & 10 & 10 & 9 & 8 & 6 & 5 \\
\hline MX1-6-B & & 10 & 9 & 9 & 6 & 5 & 5 \\
\hline$M X 1-6-C$ & & 12 & 12 & 12 & 10 & 8 & 8 \\
\hline MX1-7-A & 1 & 18 & 18 & 16 & 13 & 14 & 14 \\
\hline MX1-7-B & & 13 & 14 & 12 & 10 & 10 & 10 \\
\hline $\mathrm{MX1-7-C}$ & & 21 & 21 & 17 & 17 & 16 & 17 \\
\hline MX1-8-A & 9 & 11 & 11 & 9 & 8 & 8 & 7 \\
\hline MX1-8-B & & 10 & 9 & 9 & 8 & 6 & 5 \\
\hline $\mathrm{MX1-8-C}$ & & 12 & 11 & 11 & 9 & 8 & 9 \\
\hline MX1-9-A & 6 & 27 & 54 & 52 & 52 & 52 & 52 \\
\hline MX1-9-B & & 21 & 56 & 54 & 54 & 54 & 54 \\
\hline MX1-9-C & & 23 & 53 & 52 & 51 & 52 & 51 \\
\hline
\end{tabular}


Table E-2. Drainable-water values for grouts prepared from Matrix $2^{\mathrm{a}}$

\begin{tabular}{|c|c|c|c|c|c|c|c|}
\hline \multirow{2}{*}{$\begin{array}{l}\text { Run } \\
\text { No. }\end{array}$} & \multirow{2}{*}{$\begin{array}{c}\text { Corresponding } \\
\text { observation } \\
\text { No. }\end{array}$} & \multicolumn{6}{|c|}{ Drainable water $(\mathrm{mL})$ observed at } \\
\hline & & $2 \mathrm{~h}$ & $1 d$ & $7 \mathrm{~d}$ & $14 d$ & $21 \mathrm{~d}$ & $28 \mathrm{~d}$ \\
\hline MX2-1-A & 8 & 20 & 22 & 18 & 18 & 18 & 18 \\
\hline MX2-1-B & & 25 & 31 & 29 & 29 & 26 & 27 \\
\hline$M \times 2-1-C$ & & 18 & 18 & 15 & 14 & 14 & 14 \\
\hline$M \times 2-2-A$ & 1 & 36 & 47 & 14 & 45 & 44 & 44 \\
\hline MX2-2-B & & 36 & 49 & 46 & 47 & 46 & 46 \\
\hline $\mathrm{MX} 2-2-\mathrm{C}$ & & 28 & 51 & 49 & 47 & 47 & 46 \\
\hline$M \times 2-3-A$ & 9 & 34 & 49 & 46 & 46 & 45 & 44 \\
\hline$M \times 2-3-B$ & & 35 & 52 & 48 & 48 & 46 & 46 \\
\hline $\mathrm{MX} 2-3-\mathrm{C}$ & & 36 & 52 & 50 & 48 & 48 & 46 \\
\hline$M \times 2-4-A$ & 6 & 30 & 39 & 36 & 35 & 35 & 35 \\
\hline MX2-4-B & & 24 & 28 & 27 & 25 & 25 & 25 \\
\hline$M \times 2-4-C$ & & 32 & 40 & 38 & 35 & 36 & 36 \\
\hline$M \times 2-5-A$ & 4 & 30 & 40 & 36 & 36 & 36 & 35 \\
\hline$M \times 2-5-B$ & & 27 & 43 & 40 & 39 & 40 & 40 \\
\hline$M X 2-5-C$ & & 26 & 44 & 36 & 41 & 40 & 40 \\
\hline$M \times 2-6-A$ & 2 & 35 & 39 & 35 & 34 & 33 & 34 \\
\hline$M \times 2-6-B$ & & 30 & 31 & 28 & 27 & 26 & 27 \\
\hline$M \times 2-6-C$ & & 30 & 30 & 26 & 26 & 26 & 26 \\
\hline MX2-7-A & 3 & 22 & 26 & 21 & 22 & 19 & 19 \\
\hline MX2-7-B & & 21 & 18 & 16 & 16 & 15 & 16 \\
\hline $\mathrm{MX} 2-7-\mathrm{C}$ & & 23 & 24 & 21 & 20 & 20 & 20 \\
\hline MX2-8-A & 7 & 28 & 41 & 36 & 36 & 36 & 35 \\
\hline MX2-8-B & & 29 & 42 & 37 & 36 & 36 & 36 \\
\hline $\mathrm{MX} 2-8-\mathrm{C}$ & & 28 & 43 & 42 & 42 & 42 & 42 \\
\hline MX2-9-A & 5 & 26 & 36 & 30 & 30 & 30 & 30 \\
\hline$M \times 2-9-B$ & & 24 & 28 & 24 & 22 & 22 & 22 \\
\hline$M \times 2-9 . C$ & & 21 & 44 & 42 & 38 & 40 & 39 \\
\hline
\end{tabular}

${ }^{2} \mathrm{Bleed} \mathrm{H}_{2} \mathrm{O}$ volumes were poured from the material used for rheology measurenents and remixed with the remaining grout from initial mixing, for all specimens poured to date except MX2-9-C. This specimen was poured from the rheology cup only. As solids are retained on the viscometer $B O B$ after measurement, it is likely that this is the cause of the increased VOC of bleed water. 
Table E-3. Drainable-water values for grouts prepared from Matrix 2R

\begin{tabular}{|c|c|c|c|c|c|c|}
\hline \multirow[b]{2}{*}{ Run No. } & \multicolumn{6}{|c|}{ Drainable water $(\mathrm{mL})$ observed at } \\
\hline & $2 \mathrm{~h}$ & $1 \mathrm{~d}$ & $7 d$ & $14 \mathrm{~d}$ & $21 \mathrm{~d}$ & $28 \mathrm{~d}$ \\
\hline MX2R-1-A & 10 & $9^{a}$ & $8^{a}$ & $6^{a}$ & $4^{a}$ & $2^{a}$ \\
\hline$M \times 2 R-1-B$ & 10 & 8 & 8 & 7 & 5 & 5 \\
\hline MX2R-1-C & 9 & 10 & 9 & 8 & 8 & $4^{a}$ \\
\hline MX2R-2-A & 30 & 32 & 31 & 30 & 30 & 30 \\
\hline MX2R-2-B & 28 & 34 & 34 & 33 & 33 & 32 \\
\hline$M X 2 R-2-C$ & 26 & 28 & 28 & 27 & 27 & 26 \\
\hline MX2R-3-A & 30 & 36 & 36 & 36 & 36 & 37 \\
\hline MX2R-3-B & 30 & 36 & 36 & 36 & 36 & 36 \\
\hline$M \times 2 R-3-C$ & 32 & 33 & 32 & 32 & 32 & 32 \\
\hline$M X 2 R-4-A$ & 18 & 22 & 18 & 18 & 18 & 18 \\
\hline MX2R-4-B & 18 & 21 & 18 & 18 & 18 & 18 \\
\hline$M X 2 R-4-C$ & 17 & 17 & 16 & 16 & 15 & 15 \\
\hline MX2R-5-A & 21 & 22 & 22 & 22 & 21 & 21 \\
\hline$M X 2 R-5-B$ & 24 & 26 & 24 & 23 & 22 & 21 \\
\hline$M \times 2 R-5-C$ & 24 & 26 & 23 & 22 & 23 & 21 \\
\hline MX2R-6-A & 30 & 32 & 31 & 30 & 29 & 29 \\
\hline$M X 2 R-6-B$ & 31 & 32 & 29 & 29 & 30 & 27 \\
\hline$M X 2 R-6-C$ & 32 & 32 & 31 & 30 & 30 & 30 \\
\hline $\mathrm{MX} 2 \mathrm{R}-7-\mathrm{A}$ & 19 & 18 & 18 & 16 & 16 & 16 \\
\hline MX2R-7-B & 20 & 19 & 18 & 15 & 15 & 14 \\
\hline$M X 2 R \cdot 7-C$ & 22 & 22 & 20 & 18 & 18 & 18 \\
\hline MX2R-8-A & 24 & 26 & 22 & 21 & 21 & 21 \\
\hline MX2R-8-B & 23 & 26 & 21 & 20 & 20 & 19 \\
\hline$M X 2 R-8-C$ & 24 & 29 & 28 & 26 & 26 & 26 \\
\hline MX2R-9-A & 19 & 18 & 16 & 14 & 14 & 13 \\
\hline MX2R-9-B & 19 & 18 & 16 & 16 & 15 & 15 \\
\hline MX2R-9.C & 18 & 16 & 14 & 12 & 12 & 12 \\
\hline
\end{tabular}

${ }^{2}$ Cylinder leaked. 
Table E-4. Drainable-water values for grouts prepared from Matrix 3

\begin{tabular}{|c|c|c|c|c|c|c|}
\hline \multirow[b]{2}{*}{ Run No. } & \multicolumn{6}{|c|}{ Drainable water $(\mathrm{mL})$ observed at } \\
\hline & $2 \mathrm{~h}$ & $1 \mathrm{~d}$ & $7 d$ & $14 d$ & $21 d$ & $28 \mathrm{~d}$ \\
\hline$M \times 3-1-A$ & 24 & 32. & 27 & 27 & 26 & 26 \\
\hline $\mathrm{MX3}-1-\mathrm{B}$ & 13 & 18 & 13 & 12 & 13 & 13 \\
\hline $\mathrm{MX} 3-1-\mathrm{C}$ & 17 & 23 & 17 & 18 & 17 & 16 \\
\hline$M \times 3-2-A$ & 24 & 26 & 23 & 22 & 22 & 20 \\
\hline$M \times 3-2-B$ & 18 & 22 & 18 & 16 & 16 & 15 \\
\hline$M \times 3-2-C$ & 31 & 36 & 34 & 33 & 32 & 31 \\
\hline$M \times 3-3-A$ & 25 & 23 & 21 & 20 & 20 & 20 \\
\hline MX3-3-B & 12 & 13 & 8 & 9 & 8 & 8 \\
\hline $\mathrm{MX3-3-C}$ & 12 & 13 & 12 & 12 & 11 & 10 \\
\hline$M \times 3-4-A$ & 30 & 32 & 30 & 28 & 28 & 29 \\
\hline MX3-4-B & 31 & 35 & 33 & 33 & 33 & 33 \\
\hline$M \times 3-4-C$ & 29 & 37 & 33 & 34 & 33 & 32 \\
\hline$M \times 3-5-A$ & 26 & 29 & 27 & 26 & 26 & 26 \\
\hline MX3-5-B & 23 & 23 & 22 & 21 & 20 & 20 \\
\hline$M \times 3-5-C$ & 18 & 19 & 17 & 16 & 16 & 16 \\
\hline$M \times 3-6-A$ & 12 & 20 & 18 & 18 & 18 & 18 \\
\hline$M \times 3-6-B$ & 22 & 25 & 23 & 24 & 24 & 24 \\
\hline$M \times 3-6-C$ & 13 & 23 & 21 & 20 & 19 & 20 \\
\hline MX3-7-A & 14 & 48 & 45 & 45 & 45 & 45 \\
\hline MX3-7-B & 25 & 41 & 38 & 39 & 38 & 38 \\
\hline$M X 3-7-C$ & 28 & 47 & 36 & 36 & 36 & 36 \\
\hline MX3-8-A & 25 & 35 & 32 & 32 & 33 & 32 \\
\hline MX3-8-B & 26 & 28 & 27 & 26 & 26 & 26 \\
\hline$M \times 3-8-C$ & 22 & 33 & 30 & 29 & 30 & 29 \\
\hline MX3-9-A & 23 & 26 & 24 & 22 & 22 & 22 \\
\hline$M \times 3-9-B$ & 16 & 18 & 15 & 14 & 14 & 14 \\
\hline$M X 3-9-C$ & 22 & 25 & 22 & 22 & 22 & 22 \\
\hline
\end{tabular}


Table E-5. Drainable-water values for grouts prepared from Matrix 4

\begin{tabular}{|c|c|c|c|c|c|c|}
\hline \multirow[b]{2}{*}{ Run No. } & \multicolumn{6}{|c|}{ Drainable water $(\mathrm{mL})$ observed at } \\
\hline & $2 \mathrm{~h}$ & $1 \mathrm{~d}$ & $7 d$ & $14 \mathrm{~d}$ & $21 \mathrm{~d}$ & $28 d$ \\
\hline MX4-1-A & 24 & 27 & 24 & 24 & 24 & 24 \\
\hline MX4-1-B & 25 & 26 & 24 & 24 & 24 & 24 \\
\hline MX4-1-C & 14 & 14 & 11 & 11 & 11 & 10 \\
\hline MX4-2-A & 14 & 15 & 12 & 11 & 10 & 10 \\
\hline MX4-2-B & 11 & 12 & 8 & 8 & 7 & 6 \\
\hline $\mathrm{MX} 4-2-\mathrm{C}$ & 10 & 10 & 7 & 6 & 5 & 5 \\
\hline MX4-3-A & 12 & 10 & 6 & 5 & $2^{a}$ & $0^{a}$ \\
\hline MX4-3-B & 15 & 14 & 11 & 11 & 10 & 10 \\
\hline MX4-3-C & 15 & 16 & 14 & 14 & 12 & 12 \\
\hline MX4-4-A & 14 & 14 & 10 & 10 & 10 & 8 \\
\hline MX4-4-B & 10 & 10 & 7 & 6 & 5 & 4 \\
\hline MX4-4-C & 12 & 10 & 6 & 6 & 6 & 4 \\
\hline$M X 4-5-A$ & 20 & 22 & 20 & 18 & 18 & 18 \\
\hline MX4-5-B & 18 & 21 & 20 & 18 & 18 & 17 \\
\hline MX4-5-C & 14 & 16 & 13 & 12 & 12 & 12 \\
\hline MX4-6-A & 25 & 30 & 28 & 28 & 27 & 26 \\
\hline MX4-6-B & 26 & 32 & 32 & 30 & 30 & 30 \\
\hline MX4-6-C & 27 & 30 & 28 & 28 & 28 & 27 \\
\hline$M \times 4-7-A$ & 21 & 23 & 19 & 18 & 18 & 18 \\
\hline $\mathrm{MX} 4-7-\mathrm{B}$ & 21 & 23 & 19 & 18 & 18 & 18 \\
\hline$M \times 4-7-C$ & 18 & 21 & 17 & 16 & 16 & 16 \\
\hline MX4-8-A & 12 & 11 & 8 & 8 & 8 & 8 \\
\hline MX4-8-B & 8 & 10 & 4 & 4 & 4 & 4 \\
\hline$M X 4-8-C$ & 14 & 14 & 12 & 12 & 12 & 12 \\
\hline MX4-9-A & 19 & 21 & 18 & 17 & 17 & 17 \\
\hline MX4-9.B & 20 & 25 & 22 & 22 & 21 & 20 \\
\hline MX4-9.C & 20 & 22 & 18 & 18 & 18 & 17 \\
\hline
\end{tabular}

'Cylinder cracked and bleed water evaporated. 
Table E-6. Drainable-water values for grouts prepared from Matrix 5

\begin{tabular}{|c|c|c|c|c|c|c|}
\hline \multirow[b]{2}{*}{ Run No. } & \multicolumn{6}{|c|}{ Drainable water $(\mathrm{mL}$ ) observed at } \\
\hline & $2 \mathrm{~h}$ & $1 \mathrm{~d}$ & $7 d$ & $14 d$ & $21 \mathrm{~d}$ & $28 d$ \\
\hline$M \times 5.1-A$ & 14 & 16 & 12 & 12 & 12 & 12 \\
\hline MX5-1-B & 10 & 12 & 8 & 11 & 8 & 8 \\
\hline MX5-1-C & 10 & 16 & 9 & 11 & 8 & 8 \\
\hline$M \times 5-2-A$ & 21 & 26 & 23 & 22 & 22 & 22 \\
\hline MX5-2-B & 22 & 28 & 25 & 26 & 24 & 23 \\
\hline$M \times 5-2-C$ & 24 & 26 & 22 & 22 & 22 & 22 \\
\hline MX5-3-A & 20 & 22 & 18 & 18 & 18 & 18 \\
\hline MX5-3-B & 20 & 22 & 21 & 19 & 19 & 19 \\
\hline $\mathrm{MX5}-3-\mathrm{C}$ & 20 & 22 & 18 & 18 & 18 & 18 \\
\hline$M \times 5-4 \cdot A$ & 16 & 17 & 14 & 14 & 13 & 13 \\
\hline MX5-4-B & 19 & 20 & 18 & 18 & 17 & 16 \\
\hline$M \times 5-4-C$ & 18 & 18 & 15 & 14 & 14 & 14 \\
\hline MX5-5-A & 15 & 18 & 13 & 13 & 13 & 11 \\
\hline MX5 5-B & 14 & 16 & 12 & 12 & 12 & 9 \\
\hline$M \times 5-5-C$ & 14 & 20 & 16 & 16 & 16 & 14 \\
\hline$M X 5-6-A$ & 9 & 10 & 5 & 5 & & 4 \\
\hline MX5-6-B & 12 & 12 & 10 & 10 & & 8 \\
\hline$M \times 5-6-C$ & 12 & 12 & 8 & 8 & & 5 \\
\hline MX5.7.A & 9 & 8 & 6 & 4 & & 4 \\
\hline $\mathrm{MX5-7-B}$ & 7 & 8 & 6 & 4 & & 4 \\
\hline MX5-7-C & 7 & 8 & 5 & 3 & & 3 \\
\hline MX5-8.A & 10 & 16 & 12 & 11 & 10 & 10 \\
\hline MX5-8-B & 8 & 10 & 8 & 7 & 7 & 6 \\
\hline$M \times 5-8 . C$ & 12 & 12 & 10 & 8 & 8 & 7 \\
\hline MX5.9-A & 14 & 22 & 18 & 18 & 17 & 17 \\
\hline MX5-9-B & 11 & 15 & 10 & 8 & 8 & 8 \\
\hline MX5-9.C & 16 & 18 & 16 & 13 & 13 & 13 \\
\hline
\end{tabular}


Table E-7. Drainable-water values for grouts prepared from Matrix 6

\begin{tabular}{|c|c|c|c|c|c|c|}
\hline \multirow[b]{2}{*}{ Run No. } & \multicolumn{6}{|c|}{ Drainable water $(\mathrm{mL})$ observed at } \\
\hline & $2 \mathrm{~h}$ & $1 d$ & $7 d$ & $14 \mathrm{~d}$ & $21 d$ & $28 \mathrm{~d}$ \\
\hline MX6-1-A & 10 & 11 & 8 & 6 & 6 & 5 \\
\hline MX6-1-B & 7 & 6 & 5 & 3 & 3 & 3 \\
\hline $\mathrm{MX6}-1-\mathrm{C}$ & 6 & 7 & 5 & 2 & 2 & 2 \\
\hline MX6-2-A & 15 & 15 & 14 & 11 & 11 & 11 \\
\hline $\mathrm{MX6-2-B}$ & 12 & 12 & 9 & 8 & 8 & 8 \\
\hline $\mathrm{MX6-2-C}$ & 12 & 12 & 11 & 8 & 8 & 8 \\
\hline MX6-3-A & 7 & 9 & 4 & 4 & 4 & 4 \\
\hline MX6-3-B & 7 & 9 & 4 & 5 & 4 & 4 \\
\hline$M \times 6-3-C$ & 8 & 10 & 4 & 54 & 4 & 4 \\
\hline MX6-4-A & 8 & 10 & 5 & 5 & 5 & 4 \\
\hline MX6-4-B & 6 & 7 & 3 & 2 & 2 & 2 \\
\hline MX6-4-C & 7 & 6 & 2 & 2 & 2 & 1 \\
\hline MX6-5-A & 19 & 22 & 19 & 18 & 18 & 16 \\
\hline MX6-5-B & 19 & 21 & 20 & 18 & 18 & 17 \\
\hline MX6-5-C & 14 & 15 & 13 & 11 & 11 & 10 \\
\hline MX6-6-A & 9 & 10 & 7 & 6 & 6 & 6 \\
\hline MX6-6-B & 11 & 13 & 10 & 10 & 9 & 8 \\
\hline MX6-6-C & 12. & 12 & 9 & 7 & 7 & 6 \\
\hline$M \times 6-7-A$ & 14 & 16 & 12 & 11 & 11 & 11 \\
\hline $\mathrm{MX6-7-B}$ & 16 & 18 & 15 & 14 & 14 & 14 \\
\hline$M \times 6-7-C$ & 14 & 14 & 11 & 10 & 10 & 10 \\
\hline$M \times 6-8-A$ & 19 & 22 & 20 & 20 & 19 & 18 \\
\hline MX6-8-B & 20 & 13 & 10 & 9 & 9 & 8 \\
\hline $\mathrm{MX6-8-C}$ & 12 & 13 & 12 & 10 & 10 & 9 \\
\hline MX6-9-A & 10 & 10 & 7 & 6 & 6 & 6 \\
\hline MX6-9-B & 6 & $\cdot$ & & & & \\
\hline MX6.9-C & 8 & 8 & 6 & 5 & 5 & 3 \\
\hline
\end{tabular}

'Leakir.g cylinder. 
Table E-8. Drainable-water values for grouts prepared from Matrix 7

\begin{tabular}{|c|c|c|c|c|c|c|}
\hline \multirow[b]{2}{*}{ Run No. } & \multicolumn{6}{|c|}{ Drainable water ( $\mathrm{mL}$ ) observed at } \\
\hline & $2 \mathrm{~h}$ & $1 \mathrm{~d}$ & $7 d$ & $14 \mathrm{~d}$ & $21 \mathrm{~d}$ & $28 d$ \\
\hline MX7-1-A & 5 & 6 & 5 & 4 & 4 & 4 \\
\hline MX7-1-B & 6 & 12 & 11 & 10 & 10 & 10 \\
\hline $\mathrm{MX} 7-1-\mathrm{C}$ & 10 & 12 & 11 & 10 & 9 & 9 \\
\hline$M \times 7-2 \cdot A$ & 5 & 4 & 4 & 4 & 3 & 2 \\
\hline$M \times 7-2-B$ & 5 & 4 & 4 & 4 & 3 & 2 \\
\hline$M \times 7-2-C$ & 6 & 5 & 4 & 4 & 3 & 2 \\
\hline$M \times 7-3-A$ & 13 & 13 & 11 & 10 & 10 & 10 \\
\hline$M X 7-3-B$ & 10 & 11 & 10 & 9 & 9 & 9 \\
\hline $\mathrm{MX7-3-C}$ & 10 & 9 & 9 & 8 & 7 & 7 \\
\hline$M \times 7-4-A$ & 14 & 22 & 21 & 18 & 18 & 18 \\
\hline$M \times 7-4 . B$ & 14 & 19 & 18 & 16 & 16 & 16 \\
\hline$M \times 7-4-C$ & 16 & 20 & 19 & 19 & 18 & 17 \\
\hline$M X 7-5-A$ & 11 & 11 & 10 & 10 & 9 & 8 \\
\hline$M \times 7-5-B$ & 8 & 9 & 6 & 6 & 6 & 5 \\
\hline$M \times 7-5-C$ & 11 & 11 & 10 & 8 & 8 & 8 \\
\hline$M \times 7-6-A$ & 6 & 6 & 4 & 4 & 4 & 4 \\
\hline MX7-6-B & 6 & 6 & 3 & 4 & 3 & 2 \\
\hline$M \times 7-6-C$ & 5 & 5 & 2 & 2 & 2 & 2 \\
\hline$M \times 7-7-A$ & 10 & 11 & 10 & 8 & 8 & 7 \\
\hline$M \times 7-7-B$ & 11 & 12 & 10 & 10 & 10 & 9 \\
\hline$M \times 7-7 . C$ & 15 & 16 & 15 & 14 & 14 & 14 \\
\hline$M \times 7 \cdot 8 \cdot A$ & 5 & 4 & 4 & 3 & 3 & 2 \\
\hline$M \times 7-8-B$ & 5 & 5 & 4 & 3 & 3 & 3 \\
\hline$M \times 7-8-C$ & 6 & 6 & 4 & 3 & 3 & 2 \\
\hline$M \times 7-9-A$ & 12 & 9 & 9 & 9 & 9 & 9 \\
\hline MX7-9.B & 10 & 8 & 8 & 8 & 6 & 6 \\
\hline MX7-9.C & 8 & 6 & 6 & 6 & 5 & 5 \\
\hline
\end{tabular}


Table E-9. Drainable-water values for grouts prepared from Matrix 8

\begin{tabular}{|c|c|c|c|c|c|c|}
\hline \multirow[b]{2}{*}{ Run No. } & \multicolumn{6}{|c|}{ Drainable water ( $\mathrm{mL}$ ) observed at } \\
\hline & $2 \mathrm{~h}$ & $1 \mathrm{~d}$ & $7 d$ & $14 d$ & $21 \mathrm{~d}$ & $28 \mathrm{~d}$ \\
\hline MX8-1-A & 8 & 6 & 4 & 4 & 4 & 4 \\
\hline MX8-1-B & 8 & 8 & 5 & 5 & 5 & 4 \\
\hline MX8-1-C & 9 & 11 & 11 & 11 & 10 & 9 \\
\hline MX8-2-A & 16 & 18 & 17 & 16 & 16 & 15 \\
\hline MX8-2-B & 17 & 19 & 18 & 18 & 17 & 16 \\
\hline $\mathrm{MX8-2.C}$ & 16 & 18 & 17 & 16 & 15 & 14 \\
\hline MX8-3-A & 11 & 10 & 10 & 9 & 7 & 7 \\
\hline MX8-3-B & 9 & 10 & 9 & 8 & 7 & 6 \\
\hline $\mathrm{MX8-3-C}$ & 6 & 4 & 4 & 4 & $3^{a}$ & 2 \\
\hline MX8-4-A & 16 & 16 & 13 & 13 & 13 & 12 \\
\hline MX8-4-B & 16 & 16 & 15 & 14 & 14 & 14 \\
\hline MX8-4-C & 18 & 17 & 15 & 15 & 15 & 14 \\
\hline MX8-5-A & 19 & 21 & 20 & 20 & 19 & 18 \\
\hline MX8-5-B & 17 & 17 & 15 & 14 & 14 & 14 \\
\hline$M X 8-5 \cdot C$ & 20 & 20 & 20 & 19 & 17 & 18 \\
\hline MX8-6-A & 18 & 20 & 18 & 17 & 16 & 17 \\
\hline MX8-6-B & 18 & 20 & 18 & 17 & 16 & 16 \\
\hline$M \times 8-6-C$ & 20 & 20 & 17 & 16 & 16 & 15 \\
\hline $\mathrm{MX8-7.A}$ & 18 & 19 & 18 & 18 & 17 & 17 \\
\hline MX8-7-B & 20 & 24 & 22 & 21 & 21 & 20 \\
\hline MX8-7.C & 21 & 23 & 22 & 22 & 21 & 20 \\
\hline MX8-8-A & 14 & 16 & 16 & 14 & 14 & 14 \\
\hline MX8-8-B & 14 & 13 & 13 & 11 & 11 & 11 \\
\hline$M \times 8-8-C$ & 14 & 14 & 13 & 11 & 11 & 11 \\
\hline MX8-9-A & 6 & 6 & 5 & 4 & 4 & 4 \\
\hline MX8-9-B & 6 & $6^{2}$ & $2^{a}$ & $0^{n}$ & $0^{a}$ & $0^{2}$ \\
\hline MX8-9-C & 7 & 7 & 6 & 6 & 5 & 4 \\
\hline
\end{tabular}

•Container cracked. 
Table E-10. Drainable-water values for grouts prepared from Matrix 9

\begin{tabular}{|c|c|c|c|c|c|c|}
\hline \multirow[b]{2}{*}{ Run No. } & \multicolumn{6}{|c|}{ Drainable water $(\mathrm{mL})$ observed at } \\
\hline & $2 \mathrm{~h}$ & $1 \mathrm{~d}$ & $7 d$ & $14 \mathrm{~d}$ & $21 d$ & $28 \mathrm{~d}$ \\
\hline$M \times 9-1-A$ & 17 & 19 & 17 & 17 & 15 & 16 \\
\hline MX9.1.B & 16 & 18 & 16 & 16 & 14 & 14 \\
\hline MX9-1-C & 17 & 18 & 16 & 15 & 14 & 15 \\
\hline$M \times 9-2-A$ & 20 & 23 & 23 & 20 & 19 & 19 \\
\hline $\mathrm{MX9-2-B}$ & 20 & 24 & 22 & 23 & 22 & 22 \\
\hline$M \times 9-2-C$ & 20 & 20 & 18 & 18 & 18 & 18 \\
\hline MX9-3-A & 24 & 24 & 22 & 22 & 22 & 22 \\
\hline MX9-3-B & 27 & 34 & 31 & 31 & 29 & 30 \\
\hline$M \times 9-3-C$ & 24 & 24 & 21 & 21 & 22 & 22 \\
\hline MX9-4-A & 17 & 20 & 18 & 18 & 17 & 16 \\
\hline MX9-4-B & 12 & 12 & 16 & $9^{a}$ & $9^{a}$ & $9^{a}$ \\
\hline$M \times 9-4-C$ & 17 & 18 & 18 & 15 & 14 & 15 \\
\hline MX9-5-A & 20 & 22 & 19 & 18 & 18 & 18 \\
\hline MX9.5-B & 19 & 22 & 19 & 18 & 18 & 18 \\
\hline MX9-5-C & 20 & 20 & 18 & 16 & 15 & 16 \\
\hline MX9-6-A & 20 & 21 & 18 & 18 & 18 & 16 \\
\hline MX9-6-B & 22 & 23 & 20 & 20 & 20 & 20 \\
\hline MX9-6-C & 19 & 21 & 20 & 19 & 18 & 17 \\
\hline MX9-7-A & 15 & 16 & 13 & 12 & 12 & 12 \\
\hline MX9.7-B & 12 & 11 & 9 & 8 & 8 & 8 \\
\hline MX9-7.C & 18 & 22 & 19 & $18^{a}$ & $16^{\mathrm{a}}$ & $10^{2}$ \\
\hline MX9.8-A & 23 & 26 & 24 & 24 & 23 & 22 \\
\hline MX9-8-B & 25 & 27 & 24 & 23 & 24 & 23 \\
\hline $\mathrm{MX9-8-C}$ & 21 & 23 & 20 & 20 & 20 & 20 \\
\hline MX9-9.A & 18 & 19 & 17 & 15 & 16 & 15 \\
\hline MX9-9-B & 15 & 16 & 14 & 12. & 13 & 12 \\
\hline MX9-9-C & 16 & 16 & 12 & 12 & 12 & 11 \\
\hline
\end{tabular}

"Cylinder leaked. 
Table E-11. Drainable-water values for grouts prepared from Matrix 10

\begin{tabular}{|c|c|c|c|c|c|c|}
\hline \multirow[b]{2}{*}{ Run No. } & \multicolumn{6}{|c|}{ Drainable water $(\mathrm{mL})$ observed at } \\
\hline & $2 \mathrm{~h}$ & $1 \mathrm{~d}$ & $7 d$ & $14 \mathrm{~d}$ & $21 \mathrm{~d}$ & $28 \mathrm{~d}$ \\
\hline MX10-1-A & 20 & 24 & 21 & 20 & 20 & 20 \\
\hline $\mathrm{MX} 10-1-\mathrm{B}$ & 20 & 24 & 20 & 20 & 20 & 17 \\
\hline MX10-1-C & 21 & 25 & 22 & 22 & 21 & 21 \\
\hline $\mathrm{MX10-2-A}$ & 18 & 20 & 17 & 15 & 14 & 14 \\
\hline$M \times 10-2-B$ & 18 & 22 & 20 & 19 & 20 & 20 \\
\hline $\mathrm{MX10-2-C}$ & 20 & 18 & 16 & 14 & 15 & 14 \\
\hline$M \times 10-3-A$ & 19 & 18 & 17 & 16 & 14 & 15 \\
\hline MX10-3-B & 19 & 18 & 16 & 16 & 16 & 16 \\
\hline $\mathrm{MX} 10-3-\mathrm{C}$ & 19 & 20 & 16 & 16 & 16 & 16 \\
\hline $\mathrm{M} \times 10-4-\mathrm{A}$ & 17 & 20 & 16 & 16 & 15 & 15 \\
\hline$M \times 10-4-B$ & 18 & 20 & 18 & 17 & 16 & 15 \\
\hline $\mathrm{MX} 10-4-\mathrm{C}$ & 19 & 21 & 17 & 18 & 18 & 16 \\
\hline $\mathrm{M} \times 10-5-\mathrm{A}$ & 20 & 23 & 22 & 21 & 20 & 19 \\
\hline$M \times 10-5-B$ & 22 & 25 & 21 & 21 & 21 & 21 \\
\hline $\mathrm{MX} 10-5-\mathrm{C}$ & 20 & 22 & 18 & 18 & 18 & 18 \\
\hline$M \times 10-6-A$ & 29 & 30 & 26 & 27 & 26 & 26 \\
\hline MX10-6-B & 30 & 31 & 28 & 28 & 28 & 27 \\
\hline$M \times 10-6-C$ & 30 & 39 & 37 & 36 & 36 & 36 \\
\hline$M \times 10-7-A$ & 24 & 26 & 22 & 22 & 22 & 22 \\
\hline $\mathrm{MX10-7-B}$ & 26 & 28 & 25 & 25 & 25 & 24 \\
\hline $\mathrm{M} \times 10-7-\mathrm{C}$ & 27 & 30 & 26 & 25 & 24 & 24 \\
\hline$M X 10-8-A$ & 22 & 23 & 19 & 18 & 18 & 18 \\
\hline MX10-8-B & 22 & 25 & 21 & 22 & 21 & 21 \\
\hline$M \times 10-8-C$ & 22 & 24 & 19 & 18 & 18 & 18 \\
\hline MX10-9-A & 27 & 30 & 29 & 28 & 28 & 27 \\
\hline MX10-9-B & 28 & 30 & 27 & 28 & 36 & 26 \\
\hline MX10-9-C & 23 & 31 & 30 & 30 & 29 & 29 \\
\hline
\end{tabular}


Table E-12. Drainable-water values for grouts prepared from Matrix 11

\begin{tabular}{|c|c|c|c|c|c|c|}
\hline \multirow[b]{2}{*}{ Run No. } & \multicolumn{6}{|c|}{ Drainable water $(\mathrm{mL})$ observed at } \\
\hline & $2 \mathrm{~h}$ & $1 \mathrm{~d}$ & $7 d$ & $14 d$ & $21 \mathrm{~d}$ & $28 \mathrm{~d}$ \\
\hline $\mathrm{MX} 11-1-\mathrm{A}$ & 22 & 24 & 23 & 22 & 20 & 20 \\
\hline$M \times 11-1-B$ & 21 & 23 & 23 & 22 & 20 & 20 \\
\hline $\mathrm{MX} 11-1-\mathrm{C}$ & 20 & 25 & 24 & 24 & 22 & 22 \\
\hline $\mathrm{MX} 11-2-\mathrm{A}$ & 16 & 17 & 15 & 14 & 14 & 14 \\
\hline $\mathrm{MX} 11-2-\mathrm{B}$ & 18 & 22 & 19 & 18 & 18 & 18 \\
\hline $\mathrm{MX} 11-2-\mathrm{C}$ & 20 & 22 & 20 & 20 & 18 & 18 \\
\hline$M X 11-3-A$ & 19 & 20 & 19 & 18 & 18 & 17 \\
\hline MX11-3-B & 17 & 17 & 15 & 14 & 14 & 14 \\
\hline MX11-3-C & 20 & 21 & 19 & 18 & 16 & 16 \\
\hline $\mathrm{MX} 11-4-\mathrm{A}$ & 20 & 23 & 20 & 20 & 19 & 18 \\
\hline MX11-4-B & 19 & 21 & 19 & 18 & 18 & 18 \\
\hline$M X 11-4-C$ & 19 & 22 & 21 & 20 & 20 & 18 \\
\hline$M X 11-5-A$ & 26 & 29 & 28 & 26 & 26 & 25 \\
\hline MX11-5-B & 28 & 30 & 29 & 28 & 27 & 26 \\
\hline$M X 11-5-C$ & 24 & 24 & 23 & 23 & 23 & 22 \\
\hline$M X 11-6-A$ & 20 & 25 & 24 & 24 & 23 & 22 \\
\hline$M \times 11-6-B$ & 22 & 24 & 22 & 22 & 22 & 21 \\
\hline$M X 11-6-C$ & 26 & 28 & 26 & 26 & 26 & 26 \\
\hline$M X 11-7-A$ & 18 & 20 & 17 & 16 & 16 & 16 \\
\hline $\mathrm{MX} 11-7-\mathrm{B}$ & 19 & 19 & 17 & 16 & 16 & 16 \\
\hline $\mathrm{MX} 11-7-\mathrm{C}$ & 18 & 21 & 19 & 18 & 18 & 18 \\
\hline MX11-8-A & 22 & 24 & 22 & 21 & 21 & 21 \\
\hline$M X 11-8-B$ & 23 & 24 & 23 & 23 & 21 & 21 \\
\hline $\mathrm{MX} 11-8-\mathrm{C}$ & 21 & 22 & 20 & 19 & 18 & 18 \\
\hline MX11-9-A & 23 & 27 & 26 & 25 & 24 & 24 \\
\hline MX11-9-B & 24 & 28 & 26 & 27 & 26 & 26 \\
\hline MX11-9-C & 31 & 33 & 31 & 30 & 30 & 29 \\
\hline
\end{tabular}


Table E-13. Drainable-water values for grouts prepared from Matrix 12

\begin{tabular}{|c|c|c|c|c|c|c|}
\hline \multirow[b]{2}{*}{ Run No. } & \multicolumn{6}{|c|}{ Drainable water $(\mathrm{mL})$ observed at } \\
\hline & $2 \mathrm{~h}$ & $1 \mathrm{~d}$ & $7 d$ & $14 \mathrm{~d}$ & $21 \mathrm{~d}$ & $28 \mathrm{~d}$ \\
\hline$M X 12-1-A$ & 12 & 12 & 10 & 9 & 9 & 9 \\
\hline MX12-1-B & 12 & 14 & 11 & 11 & 11 & 11 \\
\hline $\mathrm{MX12-1-C}$ & 13 & 14 & 11 & 10 & 10 & 10 \\
\hline $\mathrm{MX} 12-2-\mathrm{A}$ & 16 & 18 & 14 & 14 & 14 & 14 \\
\hline MX12-2-B & 16 & 18 & 14 & 14 & 14 & 14 \\
\hline $\mathrm{MX12-2-C}$ & 17 & 16 & 12 & 12 & 12 & 12 \\
\hline$M X 12-3-A$ & 16 & 17 & 15 & 15 & 15 & 15 \\
\hline$M \times 12-3-B$ & 16 & 17 & 14 & 14 & 14 & 14 \\
\hline $\mathrm{MX12-3-C}$ & 17 & 22 & 19 & 19 & 19 & 19 \\
\hline $\mathrm{MX} 12-4-\mathrm{A}$ & 14 & 14 & 10 & 10 & 10 & 10 \\
\hline $\mathrm{MX} 12-4-\mathrm{B}$ & 14 & 14 & 9 & $y$ & 9 & 9 \\
\hline$M X 12-4-C$ & 14 & 14 & 11 & 11 & 11 & 11 \\
\hline$M X 12-5-A$ & 10 & 12 & 8 & 8 & 8 & 8 \\
\hline$M X 12-5-B$ & 14 & 14 & 8 & 10 & 9 & 9 \\
\hline$M \times 12-5-C$ & 12 & 13 & 8 & 8 & 8 & 7 \\
\hline MX12-6-A & 10 & 13 & 9 & 9 & 9 & 9 \\
\hline MX12-6-B & 12 & 8 & 6 & 6 & 6 & 6 \\
\hline$M X 12-6-C$ & 14 & 14 & 12 & 12 & 12 & 12 \\
\hline$M X 12-7-A$ & 12 & 11 & 8 & 8 & 8 & 8 \\
\hline$M X 12-7-B$ & 14 & 17 & 15 & 15 & 14 & 14 \\
\hline$M X 12-7-C$ & 16 & 16 & 14 & 14 & 14 & 14 \\
\hline$M X 12-8-A$ & 14 & 17 & 14 & 14 & 14 & 14 \\
\hline $\mathrm{MX} 12-8-\mathrm{B}$ & 11 & 11 & 8 & 8 & 8 & 8 \\
\hline $\mathrm{MX12-8-C}$ & 14 & 16 & 13 & 13 & 12 & 12 \\
\hline MX12-9-A & 15 & 16 & 12 & 12 & 12 & 12 \\
\hline MX12-9-B & 12 & 12 & 10 & 10 & 9 & 9 \\
\hline MX12-9-C & 16 & 16 & 14 & 14 & 13 & 13 \\
\hline
\end{tabular}


Table E-14. Drainable-water values for grouts prepared from Matrix 13

\begin{tabular}{|c|c|c|c|c|c|c|}
\hline \multirow[b]{2}{*}{ Run No. } & \multicolumn{6}{|c|}{ Drainable water $(\mathrm{mL})$ observed at } \\
\hline & $2 \mathrm{~h}$ & $1 \mathrm{~d}$ & $7 d$ & $14 d$ & $21 \mathrm{~d}$ & $28 \mathrm{~d}$ \\
\hline$M X 13-1-A$ & 22 & 24 & 20 & 20 & 20 & 20 \\
\hline $\mathrm{MX13-1-B}$ & 20 & 22 & 17 & 16 & 16 & 16 \\
\hline$M X 13-1-C$ & 18 & 18 & 15 & 15 & 15 & 15 \\
\hline MX13-2-A & 28 & 30 & 27 & 26 & 26 & 26 \\
\hline MX13-2-B & 26 & 28 & 25 & 24 & 24 & 24 \\
\hline $\mathrm{MX13-2-C}$ & 28 & 31 & 31 & 31 & 31 & 31 \\
\hline MX13-3-A & 20 & 24 & 19 & 18 & 18 & 18 \\
\hline MX13-3-B & 20 & 20 & 16 & 16 & 16 & 16 \\
\hline $\mathrm{MX13-3-C}$ & 22 & 23 & 18 & 18 & 18 & 18 \\
\hline$M X 13-4-A$ & 16 & 19 & 16 & 16 & 15 & 15 \\
\hline MX13-4-B & 18 & 20 & 18 & 17 & 17 & 17 \\
\hline MX13-4-C & 18 & 19 & 16 & 16 & 15 & 15 \\
\hline MX13-5-A & 27 & 36 & 31 & 31 & 31 & 31 \\
\hline MX13-5-B & 24 & 32 & 25 & 25 & 25 & 25 \\
\hline$M X 13-5-C$ & 32 & 32 & 29 & 29 & 28 & 28 \\
\hline $\mathrm{MX} 13-6-\mathrm{A}$ & 18 & 20 & 16 & 16 & 16 & 16 \\
\hline MX13-6-B & 18 & 20 & 16 & 16 & 16 & 16 \\
\hline MX13-6-C & 20 & 22 & 16 & 16 & 16 & 16 \\
\hline$M X 13-7-A$ & 22 & 26 & 22 & 22 & 22 & 21 \\
\hline MX13-7-B & 23 & 26 & 22 & 21 & 21 & 21 \\
\hline $\mathrm{MX13-7-C}$ & 24 & 25 & 20 & 20 & 20 & 20 \\
\hline MX13-8-A & 25 & 27 & 23 & 23 & 23 & 22 \\
\hline MX13-8-B & 27 & 29 & 20 & 20 & 20 & 20 \\
\hline$M X 13-8-C$ & 25 & 26 & 25 & 25 & 25 & 25 \\
\hline MX13-9-A & 18 & 20 & 16 & 16 & 16 & 16 \\
\hline MX13-9-B & 18 & 21 & 18 & 18 & 18 & 18 \\
\hline MX13-9-C & 20 & 21 & 16 & 16 & 16 & 16 \\
\hline
\end{tabular}


Appendix F. UNCONFINED-COMPRESSIVE-STRENGTH DATA FOR ALL EXPERIMENTAL RUNS 
Table F-1. Unconfined compressive-strength values for grouts prepared from Matrix 1

\begin{tabular}{|c|c|c|c|c|}
\hline $\begin{array}{l}\text { Run } \\
\text { No. }\end{array}$ & \multicolumn{3}{|c|}{$\begin{array}{l}\text { Unconfined compressive strength } \\
\text { (psi) }\end{array}$} & Average $^{a}$ \\
\hline $\begin{array}{l}\text { MX1-1-A } \\
\text { MX1-1-B } \\
\text { MX1-1-C }\end{array}$ & $\begin{array}{l}465 \\
369 \\
439\end{array}$ & $\begin{array}{l}401 \\
410 \\
392\end{array}$ & $\begin{array}{l}423 \\
357 \\
382\end{array}$ & $\begin{array}{l}430 \pm 33 \\
379 \pm 28 \\
404 \pm 31\end{array}$ \\
\hline $\begin{array}{l}\text { MX1-2-A } \\
\text { MX1-2-B } \\
\text { MX1-2.C }\end{array}$ & $\begin{array}{l}474 \\
516 \\
410\end{array}$ & $\begin{array}{l}422 \\
524 \\
437\end{array}$ & $\begin{array}{l}450 \\
505 \\
519\end{array}$ & $\begin{array}{l}449 \pm 26 \\
515 \pm 10 \\
455 \pm 57\end{array}$ \\
\hline $\begin{array}{l}M X 1-3-A \\
M X 1-3-B \\
M X 1-3-C\end{array}$ & $\begin{array}{l}416 \\
392 \\
364\end{array}$ & $\begin{array}{l}441 \\
442 \\
434\end{array}$ & $\begin{array}{l}385 \\
417 \\
447\end{array}$ & $\begin{array}{l}414 \pm 28 \\
417 \pm 25 \\
415 \pm 45\end{array}$ \\
\hline $\begin{array}{l}M X 1-4-A \\
M X 1-4-B \\
M X 1-4-C\end{array}$ & $\begin{array}{l}460 \\
476 \\
527\end{array}$ & $\begin{array}{l}523 \\
446 \\
551\end{array}$ & $\begin{array}{l}522 \\
456 \\
551\end{array}$ & $\begin{array}{l}501 \pm 36 \\
493 \pm 47 \\
543 \pm 14\end{array}$ \\
\hline $\begin{array}{l}\text { MX1-5-A } \\
M X 1-5-B \\
M X 1-5-C\end{array}$ & $\begin{array}{l}354 \\
418 \\
467\end{array}$ & $\begin{array}{l}397 \\
304 \\
445\end{array}$ & $\begin{array}{l}403 \\
306 \\
494\end{array}$ & $\begin{array}{l}385 \pm 27 \\
343 \pm 66 \\
468 \pm 25\end{array}$ \\
\hline $\begin{array}{l}\text { MX1-6-A } \\
\text { MX1-6-B } \\
\text { MX1-6-C }\end{array}$ & $\begin{array}{l}627 \\
468 \\
395\end{array}$ & $\begin{array}{l}621 \\
516 \\
415\end{array}$ & $\begin{array}{l}533 \\
425 \\
344\end{array}$ & $\begin{array}{l}594 \pm 53 \\
470 \pm 45 \\
384 \pm 37\end{array}$ \\
\hline $\begin{array}{l}M X 1-7-A \\
M X 1-7-B \\
M X 1-7-C\end{array}$ & $\begin{array}{l}271 \\
378 \\
358\end{array}$ & $\begin{array}{l}b \\
382 \\
439\end{array}$ & $\begin{array}{l}428 \\
357 \\
b\end{array}$ & $\begin{array}{l}350 \\
372 \pm 13 \\
398\end{array}$ \\
\hline $\begin{array}{l}M X 1-8-A \\
M X 1-8-B \\
M X 1-8-C\end{array}$ & $\begin{array}{l}396 \\
474 \\
471\end{array}$ & $\begin{array}{l}509 \\
512 \\
438\end{array}$ & $\begin{array}{l}496 \\
456 \\
369\end{array}$ & $\begin{array}{l}467 \pm 62 \\
481 \pm 29 \\
426 \pm 52\end{array}$ \\
\hline $\begin{array}{l}\text { MX1-9-A } \\
\text { MX1-9-B } \\
\text { MX1-9-C }\end{array}$ & $\begin{array}{l}308 \\
335 \\
339\end{array}$ & $\begin{array}{l}307 \\
331 \\
356\end{array}$ & $\begin{array}{l}365 \\
343 \\
318\end{array}$ & $\begin{array}{l}327 \pm 33 \\
336 \pm 6 \\
338 \pm 19\end{array}$ \\
\hline
\end{tabular}

Average value and one standard deviation.

bample cracked. 
Table F-2. Unconfined compressive-strength values for grouts prepared from Matrix 2

\begin{tabular}{|c|c|c|c|c|}
\hline $\begin{array}{l}\text { Run } \\
\text { No. }\end{array}$ & \multicolumn{3}{|c|}{$\begin{array}{l}\text { Unconfined compressive strength } \\
(\mathrm{psi})\end{array}$} & Average" \\
\hline $\begin{array}{l}M X 2-1-A \\
M X 2 \cdot 1 \cdot B \\
M X 2-1-C\end{array}$ & $\begin{array}{l}442 \\
393 \\
462\end{array}$ & $\begin{array}{l}430 \\
457 \\
402\end{array}$ & $\begin{array}{c}463 \\
b \\
464\end{array}$ & $\begin{array}{l}445 \pm 17 \\
425 \\
443 \pm 35\end{array}$ \\
\hline $\begin{array}{l}M \times 2-2 \cdot A \\
M \times 2-2 \cdot B \\
M X 2-2 \cdot C\end{array}$ & $\begin{array}{l}443 \\
393 \\
367\end{array}$ & $\begin{array}{l}386 \\
354 \\
397\end{array}$ & $\begin{array}{l}452 \\
378 \\
396\end{array}$ & $\begin{array}{l}427 \pm 36 \\
375 \pm 20 \\
387 \pm 17\end{array}$ \\
\hline $\begin{array}{l}M \times 2-3-A \\
M \times 2-3-B \\
M \times 2-3-C\end{array}$ & $\begin{array}{l}348 \\
384 \\
294\end{array}$ & $\begin{array}{l}377 \\
335 \\
313\end{array}$ & $\begin{array}{l}403 \\
334 \\
341\end{array}$ & $\begin{array}{l}376 \pm 27 \\
351 \pm 29 \\
316 \pm 24\end{array}$ \\
\hline $\begin{array}{l}M \times 2-4-A \\
M \times 2-4-B \\
M X 2-4-C\end{array}$ & $\begin{array}{l}353 \\
375 \\
315\end{array}$ & $\begin{array}{l}345 \\
338 \\
314\end{array}$ & $\begin{array}{l}331 \\
311 \\
316\end{array}$ & $\begin{array}{l}343 \pm 11 \\
341 \pm 32 \\
315 \pm 1\end{array}$ \\
\hline $\begin{array}{l}M \times 2-5-A \\
M \times 2-5-B \\
M \times 2-5-C\end{array}$ & $\begin{array}{l}368 \\
321 \\
364\end{array}$ & $\begin{array}{l}355 \\
333 \\
331\end{array}$ & $\begin{array}{l}355 \\
316 \\
369\end{array}$ & $\begin{array}{l}359 \pm 8 \\
323 \pm 9 \\
355 \pm 20\end{array}$ \\
\hline $\begin{array}{l}M X 2-6-A \\
M X 2-6-B \\
M X 2-6-C\end{array}$ & $\begin{array}{l}391 \\
335 \\
346\end{array}$ & $\begin{array}{l}349 \\
341 \\
419\end{array}$ & $\begin{array}{l}386 \\
334 \\
425\end{array}$ & $\begin{array}{l}375 \pm 23 \\
337 \pm 4 \\
397 \pm 44\end{array}$ \\
\hline $\begin{array}{l}M \times 2-7-A \\
M X 2-7-B \\
M \times 2-7-C\end{array}$ & $\begin{array}{l}340 \\
405 \\
392\end{array}$ & $\begin{array}{l}386 \\
397 \\
384\end{array}$ & $\begin{array}{l}373 \\
416 \\
365\end{array}$ & $\begin{array}{l}367 \pm 24 \\
406 \pm 9 \\
380 \pm 14\end{array}$ \\
\hline $\begin{array}{l}M X 2-8 \cdot A \\
M X 2-8-B \\
M X 2 \cdot 8-C\end{array}$ & $\begin{array}{l}375 \\
315 \\
305\end{array}$ & $\begin{array}{l}378 \\
298 \\
315\end{array}$ & $\begin{array}{l}316 \\
328 \\
304\end{array}$ & $\begin{array}{l}356 \pm 35 \\
313 \pm 15 \\
308 \pm 6\end{array}$ \\
\hline $\begin{array}{l}M \times 2.9 . A \\
M X 2.9-B \\
M X 2.9-C\end{array}$ & $\begin{array}{l}186^{c} \\
419 \\
414\end{array}$ & $\begin{array}{l}402 \\
379 \\
395\end{array}$ & $\begin{array}{l}240^{c} \\
390 \\
383\end{array}$ & $\begin{array}{l}402 \\
396 \pm 21 \\
397 \pm 16\end{array}$ \\
\hline
\end{tabular}

"Average value and one standard deviation.

bample cracked.

${ }^{c}$ Cube faces not parallel. 
Table F.3. Unconfined compressive-strength values for grouts prepared from Matrix $2 R$

\begin{tabular}{|c|c|c|c|c|}
\hline $\begin{array}{l}\text { Run } \\
\text { No. }\end{array}$ & \multicolumn{3}{|c|}{$\begin{array}{l}\text { Unconfined compressive strength } \\
\qquad(\mathrm{psi})\end{array}$} & Average $^{a}$ \\
\hline $\begin{array}{l}\text { MX2R-1-A } \\
\text { MX2R-1-B } \\
\text { MX2R-1.C }\end{array}$ & $\begin{array}{l}314 \\
329 \\
409\end{array}$ & $\begin{array}{l}388 \\
373 \\
430\end{array}$ & $\begin{array}{l}418 \\
401 \\
45.5\end{array}$ & $\begin{array}{l}373 \pm 53 \\
368 \pm 36 \\
431 \pm 23\end{array}$ \\
\hline $\begin{array}{l}\text { MX2R-2-A } \\
M X 2 R-2-B \\
M X 2 R-2-C\end{array}$ & $\begin{array}{l}330 \\
308 \\
298\end{array}$ & $\begin{array}{l}421 \\
374 \\
313\end{array}$ & $\begin{array}{l}433 \\
431 \\
388\end{array}$ & $\begin{array}{l}394 \pm 56 \\
371 \pm 61 \\
333 \pm 48\end{array}$ \\
\hline $\begin{array}{l}\text { MX2R-3-A } \\
\text { MX2R-3-B } \\
\text { MX2R-3-C }\end{array}$ & $\begin{array}{l}361 \\
315 \\
306\end{array}$ & $\begin{array}{l}335 \\
363 \\
371\end{array}$ & $\begin{array}{l}457 \\
400 \\
427\end{array}$ & $\begin{array}{l}384 \pm 64 \\
359 \pm 42 \\
368 \pm 61\end{array}$ \\
\hline $\begin{array}{l}\text { MX2R-4-A } \\
\text { MX2R-4-B } \\
\text { MX2R-4-C }\end{array}$ & $\begin{array}{l}392 \\
421 \\
320\end{array}$ & $\begin{array}{l}402 \\
404 \\
363\end{array}$ & $\begin{array}{l}430 \\
368 \\
339\end{array}$ & $\begin{array}{l}408 \pm 19 \\
398 \pm 27 \\
341 \pm 21\end{array}$ \\
\hline $\begin{array}{l}\text { MX2R-5-A } \\
M X 2 R-5-B \\
M X 2 R-5-C\end{array}$ & $\begin{array}{l}386 \\
392 \\
419\end{array}$ & $\begin{array}{l}328 \\
347 \\
352\end{array}$ & $\begin{array}{l}390 \\
396 \\
399\end{array}$ & $\begin{array}{l}368 \pm 34 \\
378 \pm 27 \\
390 \pm 34\end{array}$ \\
\hline $\begin{array}{l}\text { MX2R-6-A } \\
\text { MX2R-6-B } \\
\text { MX2R-6-C }\end{array}$ & $\begin{array}{l}366 \\
378 \\
359\end{array}$ & $\begin{array}{l}391 \\
351 \\
325\end{array}$ & $\begin{array}{l}387 \\
472 \\
318\end{array}$ & $\begin{array}{l}381 \pm 14 \\
400 \pm 64 \\
334 \pm 22\end{array}$ \\
\hline $\begin{array}{l}\text { MX2R-7-A } \\
\text { MX2R-7-B } \\
\text { MX2R-7-C }\end{array}$ & $\begin{array}{l}305 \\
325 \\
314\end{array}$ & $\begin{array}{l}334 \\
357 \\
325\end{array}$ & $\begin{array}{l}297 \\
382 \\
323\end{array}$ & $\begin{array}{l}312 \pm 20 \\
355 \pm 28 \\
321 \pm 6\end{array}$ \\
\hline $\begin{array}{l}\text { MX2R-8-A } \\
\text { MX2R-8-B } \\
M X 2 R \cdot 8-C\end{array}$ & $\begin{array}{l}282 \\
278 \\
278\end{array}$ & $\begin{array}{l}287 \\
275 \\
321\end{array}$ & $\begin{array}{l}283 \\
266 \\
319\end{array}$ & $\begin{array}{l}284 \pm 3 \\
273 \pm 6 \\
306 \pm 25\end{array}$ \\
\hline $\begin{array}{l}\text { MX2R-9-A } \\
\text { MX2R-9-B } \\
\text { MX2R-9-C }\end{array}$ & $\begin{array}{l}380 \\
368 \\
377\end{array}$ & $\begin{array}{l}345 \\
338 \\
350\end{array}$ & $\begin{array}{l}355 \\
381 \\
395\end{array}$ & $\begin{array}{l}360 \pm 18 \\
362 \pm 22 \\
374 \pm 23\end{array}$ \\
\hline
\end{tabular}

“Average value and one standard deviation. 
Table F.4. Unconfined compressive-strength values for grouts prepared from Matrix 3

\begin{tabular}{|c|c|c|c|c|}
\hline $\begin{array}{l}\text { Run } \\
\text { No. }\end{array}$ & \multicolumn{3}{|c|}{$\begin{array}{l}\text { Unconfined compressive strength } \\
\text { (psi) }\end{array}$} & Average \\
\hline $\begin{array}{l}M \times 3-1-A \\
M \times 3-1-B \\
M \times 3-1-C\end{array}$ & $\begin{array}{l}407 \\
334 \\
306\end{array}$ & $\begin{array}{l}423 \\
255 \\
271\end{array}$ & $\begin{array}{l}420 \\
327 \\
330\end{array}$ & $\begin{array}{l}417 \pm 9 \\
305 \pm 44 \\
302 \pm 29\end{array}$ \\
\hline $\begin{array}{l}\text { MX3-2-A } \\
\text { MX3-2-B } \\
\text { MX3-2-C }\end{array}$ & $\begin{array}{l}291 \\
298 \\
258\end{array}$ & $\begin{array}{l}362 \\
311 \\
277\end{array}$ & $\begin{array}{l}330 \\
287 \\
342\end{array}$ & $\begin{array}{l}328 \pm 36 \\
299 \pm 12 \\
292 \pm 44\end{array}$ \\
\hline $\begin{array}{l}M \times 3-3-A \\
M \times 3-3-B \\
M \times 3-3-C\end{array}$ & $\begin{array}{l}367 \\
231 \\
376\end{array}$ & $\begin{array}{l}357 \\
329 \\
395\end{array}$ & $\begin{array}{l}375 \\
320 \\
409\end{array}$ & $\begin{array}{l}366 \pm 9 \\
293 \pm 54 \\
394 \pm 16\end{array}$ \\
\hline $\begin{array}{l}M \times 3-4-A \\
M \times 3-4-B \\
M \times 3-4-C\end{array}$ & $\begin{array}{l}342 \\
285 \\
327\end{array}$ & $\begin{array}{l}337 \\
321 \\
329\end{array}$ & $\begin{array}{l}329 \\
355 \\
314\end{array}$ & $\begin{array}{l}336 \pm 6 \\
320 \pm 35 \\
323 \pm 8\end{array}$ \\
\hline $\begin{array}{l}M \times 3-5-A \\
M \times 3-5-B \\
M \times 3-5-C\end{array}$ & $\begin{array}{l}439 \\
448 \\
472\end{array}$ & $\begin{array}{l}424 \\
455 \\
470\end{array}$ & $\begin{array}{l}445 \\
485 \\
432\end{array}$ & $\begin{array}{l}436 \pm 10 \\
463 \pm 20 \\
458 \pm 22\end{array}$ \\
\hline $\begin{array}{l}M \times 3-6-A \\
M X 3-6-B \\
M X 3-6-C\end{array}$ & $\begin{array}{l}446 \\
427 \\
454\end{array}$ & $\begin{array}{l}445 \\
463 \\
477\end{array}$ & $\begin{array}{l}441 \\
439 \\
454\end{array}$ & $\begin{array}{l}444 \pm 3 \\
443 \pm 19 \\
462 \pm 13\end{array}$ \\
\hline $\begin{array}{l}\text { MX3-7.A } \\
\text { MX3-7.B } \\
M \times 3-7 . C\end{array}$ & $\begin{array}{l}361 \\
365 \\
353\end{array}$ & $\begin{array}{l}363 \\
351 \\
365\end{array}$ & $\begin{array}{l}371 \\
355 \\
314\end{array}$ & $\begin{array}{l}365 \pm 6 \\
357 \pm 7 \\
344 \pm 27\end{array}$ \\
\hline $\begin{array}{l}M \times 3-8-A \\
M \times 3-8-B \\
M \times 3-8-C\end{array}$ & $\begin{array}{l}305 \\
316 \\
367\end{array}$ & $\begin{array}{l}316 \\
332 \\
373\end{array}$ & $\begin{array}{l}310 \\
338 \\
358\end{array}$ & $\begin{array}{l}311 \pm 5 \\
329 \pm 12 \\
366 \pm 7\end{array}$ \\
\hline $\begin{array}{l}M X 3-9 . A \\
M X 3-9-B \\
M X 3-9 . C\end{array}$ & $\begin{array}{l}422 \\
427 \\
422\end{array}$ & $\begin{array}{l}452 \\
425 \\
442\end{array}$ & $\begin{array}{l}432 \\
414 \\
414\end{array}$ & $\begin{array}{l}435 \pm 15 \\
422 \pm 7 \\
426 \pm 14\end{array}$ \\
\hline
\end{tabular}

Average value and one standard deviation. 


\section{9}

Table F-5. Unconfined compressive-strength values for grouts prepared from Matrix 4

\begin{tabular}{|c|c|c|c|c|}
\hline $\begin{array}{l}\text { Run } \\
\text { No. }\end{array}$ & \multicolumn{3}{|c|}{$\begin{array}{l}\text { Unconfined compressive strength } \\
\text { (psi) }\end{array}$} & Average $^{a}$ \\
\hline $\begin{array}{l}\text { MX4-1-A } \\
\text { MX4-1-B } \\
\text { MX4-1-C }\end{array}$ & $\begin{array}{l}436 \\
562 \\
442\end{array}$ & $\begin{array}{l}478 \\
573 \\
431\end{array}$ & $\begin{array}{l}557 \\
554 \\
397\end{array}$ & $\begin{array}{l}490 \pm 62 \\
563 \pm 10 \\
423 \pm 24\end{array}$ \\
\hline $\begin{array}{l}M X 4-2 \cdot A \\
M X 4-2 \cdot B \\
M X 4-2 \cdot C\end{array}$ & $\begin{array}{l}517 \\
519 \\
427\end{array}$ & $\begin{array}{l}522 \\
442 \\
510\end{array}$ & $\begin{array}{l}502 \\
512 \\
551\end{array}$ & $\begin{array}{l}514 \pm 10 \\
491 \pm 42 \\
496 \pm 63\end{array}$ \\
\hline $\begin{array}{l}\text { MX4-3.A } \\
\text { MX4-3.B } \\
\text { MX4-3.C }\end{array}$ & $\begin{array}{l}485 \\
506 \\
428\end{array}$ & $\begin{array}{l}533 \\
447 \\
433\end{array}$ & $\begin{array}{l}575 \\
411 \\
386\end{array}$ & $\begin{array}{l}531 \pm 45 \\
455 \pm 48 \\
416 \pm 26\end{array}$ \\
\hline $\begin{array}{l}M X 4-4-A \\
M X 4-4-B \\
M X 4-4-C\end{array}$ & $\begin{array}{l}431 \\
440 \\
482\end{array}$ & $\begin{array}{l}470 \\
494 \\
509\end{array}$ & $\begin{array}{l}434 \\
506 \\
454\end{array}$ & $\begin{array}{l}445 \pm 22 \\
480 \pm 35 \\
482 \pm 28\end{array}$ \\
\hline $\begin{array}{l}\text { MX4-5.A } \\
\text { MX4-5.B } \\
M X 4-5-C\end{array}$ & $\begin{array}{l}368 \\
365 \\
390\end{array}$ & $\begin{array}{l}389 \\
402 \\
352\end{array}$ & $\begin{array}{l}357 \\
418 \\
383\end{array}$ & $\begin{array}{l}371 \pm 17 \\
395 \pm 27 \\
375 \pm 20\end{array}$ \\
\hline $\begin{array}{l}\text { MX4-6-A } \\
M X 4-6-B \\
M X 4-6-C\end{array}$ & $\begin{array}{l}318 \\
289 \\
320\end{array}$ & $\begin{array}{l}265 \\
328 \\
316\end{array}$ & $\begin{array}{l}292 \\
351 \\
270\end{array}$ & $\begin{array}{l}292 \pm 26 \\
323 \pm 31 \\
302 \pm 28\end{array}$ \\
\hline $\begin{array}{l}M X 4-7 . A \\
M X 4-7 . B \\
M X 4-7 . C\end{array}$ & $\begin{array}{l}426 \\
392 \\
411\end{array}$ & $\begin{array}{l}443 \\
419 \\
445\end{array}$ & $\begin{array}{l}443 \\
414 \\
446\end{array}$ & $\begin{array}{l}437 \pm 10 \\
408 \pm 14 \\
434 \pm 20\end{array}$ \\
\hline $\begin{array}{l}\text { MX4-8-A } \\
\text { MX4-8-B } \\
M X 4-8-C\end{array}$ & $\begin{array}{l}504 \\
508 \\
545\end{array}$ & $\begin{array}{l}541 \\
577 \\
569\end{array}$ & $\begin{array}{l}534 \\
559 \\
550\end{array}$ & $\begin{array}{l}526 \pm 20 \\
548 \pm 36 \\
555 \pm 13\end{array}$ \\
\hline $\begin{array}{l}\text { MX4-9.A } \\
\text { MX4-9.B } \\
\text { MX4-9.C }\end{array}$ & $\begin{array}{l}369 \\
310 \\
323\end{array}$ & $\begin{array}{l}377 \\
310 \\
263\end{array}$ & $\begin{array}{l}314 \\
284 \\
258\end{array}$ & $\begin{array}{l}354 \pm 35 \\
301 \pm 15 \\
281 \pm 36\end{array}$ \\
\hline
\end{tabular}

"Average value and one standard deviation. 
Table F-6. Unconfined compressive-strength values for grouts prepared from Matrix 5

\begin{tabular}{|c|c|c|c|c|}
\hline \multirow{2}{*}{$\begin{array}{c}\begin{array}{c}\text { Run } \\
\text { No. }\end{array} \\
\text { MX5-1.A } \\
\text { MX5-1.B } \\
\text { MX5-1.C }\end{array}$} & \multicolumn{3}{|c|}{$\begin{array}{l}\text { Unconfined compressive strength } \\
\text { (psi) }\end{array}$} & \multirow{2}{*}{$\begin{array}{l}\text { Average } \\
446 \pm 27 \\
501 \pm 37 \\
517 \pm 39\end{array}$} \\
\hline & $\begin{array}{l}435 \\
458 \\
537\end{array}$ & $\begin{array}{l}477 \\
523 \\
542\end{array}$ & $\begin{array}{l}427 \\
521 \\
473\end{array}$ & \\
\hline $\begin{array}{l}\text { MX5.2.A } \\
\text { MX5.2.B } \\
\text { MX5.2.C }\end{array}$ & $\begin{array}{l}324 \\
351 \\
360\end{array}$ & $\begin{array}{l}411 \\
361 \\
367\end{array}$ & $\begin{array}{l}368 \\
407 \\
331\end{array}$ & $\begin{array}{l}367 \neq 44 \\
373 \neq 30 \\
353 \neq 19\end{array}$ \\
\hline $\begin{array}{l}\text { MX5.3.A } \\
\text { MX5.3.B } \\
\text { MXS.3.C }\end{array}$ & $\begin{array}{l}436 \\
511 \\
455\end{array}$ & $\begin{array}{l}411 \\
510 \\
446\end{array}$ & $\begin{array}{l}449 \\
523 \\
537\end{array}$ & $\begin{array}{l}432 \pm 20 \\
515 \pm 7 \\
479 \neq 50\end{array}$ \\
\hline $\begin{array}{l}\text { MX5.4-A } \\
\text { MX5.4-B } \\
M \times 5.4 . C\end{array}$ & $\begin{array}{l}453 \\
475 \\
421\end{array}$ & $\begin{array}{l}526 \\
510 \\
505\end{array}$ & $\begin{array}{l}516 \\
470 \\
489\end{array}$ & $\begin{array}{l}499 \pm 40 \\
485 \pm 22 \\
472 \pm 45\end{array}$ \\
\hline $\begin{array}{l}\text { MX5.5.A } \\
\text { MX5.5.B } \\
\text { MX5.5.C }\end{array}$ & $\begin{array}{l}483 \\
465 \\
493\end{array}$ & $\begin{array}{l}509 \\
426 \\
406\end{array}$ & $\begin{array}{l}482 \\
399 \\
498\end{array}$ & $\begin{array}{l}491 \pm 15 \\
430 \div 33 \\
465 \pm 52\end{array}$ \\
\hline $\begin{array}{l}\text { MX5-6-A } \\
\text { MX5-6-B } \\
\text { MX5-6-C }\end{array}$ & $\begin{array}{l}410 \\
425 \\
461\end{array}$ & $\begin{array}{l}410 \\
503 \\
435\end{array}$ & $\begin{array}{l}422 \\
428 \\
b\end{array}$ & $\begin{array}{l}414 \neq 7 \\
452 \pm 44 \\
448\end{array}$ \\
\hline $\begin{array}{l}M \times 5.7 . A \\
M X 5.7 . B \\
M X 5.7 . C\end{array}$ & $\begin{array}{l}500 \\
533 \\
492\end{array}$ & $\begin{array}{l}501 \\
457 \\
481\end{array}$ & $\begin{array}{l}449 \\
492 \\
472\end{array}$ & $\begin{array}{l}483 \neq 30 \\
494 \neq 38 \\
481 \neq 10\end{array}$ \\
\hline $\begin{array}{l}\text { MX5.8-A } \\
\text { MX5.8-B } \\
\text { MX5.8.C }\end{array}$ & $\begin{array}{l}353 \\
394 \\
347\end{array}$ & $\begin{array}{l}370 \\
412 \\
371\end{array}$ & $\begin{array}{l}378 \\
409 \\
382\end{array}$ & $\begin{array}{l}367 \neq 13 \\
405 \pm 9 \\
367 \pm 18\end{array}$ \\
\hline $\begin{array}{l}\text { MX5.9.A } \\
\text { MX5.9.B } \\
\text { MX5.9.C }\end{array}$ & $\begin{array}{l}256 \\
249 \\
260\end{array}$ & $\begin{array}{l}265 \\
276 \\
249\end{array}$ & $\begin{array}{l}232 \\
222 \\
260\end{array}$ & $\begin{array}{l}251 \pm 17 \\
249 \pm 27 \\
256 \pm 7\end{array}$ \\
\hline
\end{tabular}

Average value and one standard devation.

bSample cracked. 
Table F-7. Unconfined compressive-strength values for grouts prepared from Matrix 6

\begin{tabular}{|c|c|c|c|c|}
\hline \multirow{2}{*}{$\begin{array}{l}\begin{array}{l}\text { Run } \\
\text { No. }\end{array} \\
\text { MX6-1.A } \\
\text { MX6-1.B } \\
\text { MX6.1.C }\end{array}$} & \multicolumn{3}{|c|}{$\begin{array}{l}\text { Unconfined compressive strength } \\
\text { (psi) }\end{array}$} & \multirow{2}{*}{$\begin{array}{l}\text { Average } \\
566 \pm 59 \\
615 \pm 16 \\
627 \pm 15\end{array}$} \\
\hline & $\begin{array}{l}548 \\
596 \\
613\end{array}$ & $\begin{array}{l}518 \\
626 \\
643\end{array}$ & $\begin{array}{l}631 \\
622 \\
624\end{array}$ & \\
\hline $\begin{array}{l}M X 6 \cdot 2 \cdot A \\
M X 6.2 \cdot B \\
M X 6.2 \cdot C\end{array}$ & $\begin{array}{l}529 \\
574 \\
675\end{array}$ & $\begin{array}{l}538 \\
611 \\
743\end{array}$ & $\begin{array}{l}521 \\
600 \\
710\end{array}$ & $\begin{array}{l}529 \pm 9 \\
599 \pm 19 \\
709 \pm 34\end{array}$ \\
\hline $\begin{array}{l}M \times 6 \cdot 3 \cdot A \\
M \times 6 \cdot 3 \cdot B \\
M \times 6.3 . C\end{array}$ & $\begin{array}{l}441 \\
462 \\
449\end{array}$ & $\begin{array}{l}490 \\
499 \\
427\end{array}$ & $\begin{array}{l}491 \\
394 \\
392\end{array}$ & $\begin{array}{l}474 \pm 29 \\
451 \pm 53 \\
422 \pm 29\end{array}$ \\
\hline $\begin{array}{l}\text { MX6.4.A } \\
M \times 6-4 . B \\
M \times 6-4 . C\end{array}$ & $\begin{array}{l}359 \\
412 \\
380\end{array}$ & $\begin{array}{l}405 \\
395 \\
436\end{array}$ & $\begin{array}{l}393 \\
393 \\
411\end{array}$ & $\begin{array}{l}386 \pm 24 \\
400 \pm 11 \\
409 \pm 28\end{array}$ \\
\hline $\begin{array}{l}\text { MX6.5.A } \\
\text { MX6.5.B } \\
\text { MX6.5.C }\end{array}$ & $\begin{array}{l}595 \\
415 \\
379\end{array}$ & $\begin{array}{l}534 \\
354 \\
468\end{array}$ & $\begin{array}{l}461 \\
415 \\
414\end{array}$ & $\begin{array}{l}530 \pm 67 \\
395 \pm 35 \\
420 \pm 45\end{array}$ \\
\hline $\begin{array}{l}\text { MX6.6.A } \\
\text { MX6-6.B } \\
\text { MX6.6.C }\end{array}$ & $\begin{array}{l}388 \\
366 \\
428\end{array}$ & $\begin{array}{l}519 \\
377 \\
474\end{array}$ & $\begin{array}{l}494 \\
502 \\
436\end{array}$ & $\begin{array}{l}467 \pm 69 \\
415 \pm 76 \\
446 \pm 25\end{array}$ \\
\hline $\begin{array}{l}M \times 6.7 \cdot A \\
M X 6.7 . B \\
M X 6-7 . C\end{array}$ & $\begin{array}{l}545 \\
472 \\
487\end{array}$ & $\begin{array}{l}494 \\
468 \\
495\end{array}$ & $\begin{array}{l}454 \\
475 \\
440\end{array}$ & $\begin{array}{l}497 \pm 46 \\
472 \pm 3 \\
474 \pm 30\end{array}$ \\
\hline $\begin{array}{l}\text { MX6-8. } A \\
M X 6-8 \cdot B \\
M X 6-8 \cdot C\end{array}$ & $\begin{array}{l}379 \\
337 \\
321\end{array}$ & $\begin{array}{l}317 \\
390 \\
319\end{array}$ & $\begin{array}{l}304 \\
367 \\
289\end{array}$ & $\begin{array}{l}334 \pm 40 \\
365 \pm 26 \\
310 \pm 18\end{array}$ \\
\hline $\begin{array}{l}\text { MX6-9.A } \\
\text { MX6-9.B } \\
\text { MX6-9.C }\end{array}$ & $\begin{array}{l}478 \\
436 \\
460\end{array}$ & $\begin{array}{l}562 \\
460 \\
493\end{array}$ & $\begin{array}{l}498 \\
464 \\
537\end{array}$ & $\begin{array}{l}512 \div 44 \\
453 \div 15 \\
497 \neq 39\end{array}$ \\
\hline
\end{tabular}

A Average value and one standard deviation. 
Table F-8. Unconfined compressive-strength values for grouts prepared from Matrix 7

\begin{tabular}{|c|c|c|c|c|}
\hline \multirow{2}{*}{$\begin{array}{c}\begin{array}{c}\text { Run } \\
\text { No. }\end{array} \\
\text { MX7.1.A } \\
\text { MX7.1.B } \\
\text { MX7.1.C }\end{array}$} & \multicolumn{3}{|c|}{$\begin{array}{l}\text { Unconfined compressive strength } \\
\text { (psi) }\end{array}$} & \multirow{2}{*}{$\begin{array}{l}\text { Average } \\
390 \pm 38 \\
426 \pm 14 \\
472 \pm 30\end{array}$} \\
\hline & $\begin{array}{l}384 \\
434 \\
438\end{array}$ & $\begin{array}{l}431 \\
436 \\
485\end{array}$ & $\begin{array}{l}355 \\
409 \\
494\end{array}$ & \\
\hline $\begin{array}{l}M X 7.2 \cdot A \\
M X 7.2 \cdot B \\
M X 7.2 \cdot C\end{array}$ & $\begin{array}{l}463 \\
457 \\
416\end{array}$ & $\begin{array}{l}418 \\
451 \\
472\end{array}$ & $\begin{array}{l}448 \\
420 \\
445\end{array}$ & $\begin{array}{l}443 \pm 23 \\
443 \pm 20 \\
445 \pm 29\end{array}$ \\
\hline $\begin{array}{l}M \times 7.3 . A \\
M \times 7.3 . B \\
M \times 7.3 . C\end{array}$ & $\begin{array}{l}355 \\
362 \\
415\end{array}$ & $\begin{array}{l}422 \\
396 \\
396\end{array}$ & $\begin{array}{l}392 \\
362 \\
343\end{array}$ & $\begin{array}{l}390 \pm 33 \\
373 \pm 20 \\
385 \pm 38\end{array}$ \\
\hline $\begin{array}{l}M X 7.4 \cdot A \\
M X 7.4-B \\
M X 7.4 \cdot C\end{array}$ & $\begin{array}{l}249 \\
230 \\
234\end{array}$ & $\begin{array}{l}277 \\
216 \\
237\end{array}$ & $\begin{array}{l}254 \\
225 \\
203\end{array}$ & $\begin{array}{l}260 \pm 15 \\
223 \pm 7 \\
224 \pm 19\end{array}$ \\
\hline $\begin{array}{l}M X 7.5 . A \\
M X 7.5-B \\
M X 7.5 . C\end{array}$ & $\begin{array}{l}398 \\
375 \\
357\end{array}$ & $\begin{array}{l}394 \\
374 \\
360\end{array}$ & $\begin{array}{l}399 \\
316 \\
331\end{array}$ & $\begin{array}{l}397 \pm 2 \\
355 \pm 34 \\
349 \pm 16\end{array}$ \\
\hline $\begin{array}{l}M \times 7.6-A \\
M \times 7.6-B \\
M \times 7.6-C\end{array}$ & $\begin{array}{l}437 \\
485 \\
418\end{array}$ & $\begin{array}{l}470 \\
527 \\
445\end{array}$ & $\begin{array}{l}458 \\
506 \\
440\end{array}$ & $\begin{array}{l}455 \pm 17 \\
506 \pm 21 \\
434 \pm 14\end{array}$ \\
\hline $\begin{array}{l}M \times 7.7 . A \\
M \times 7.7 . B \\
M \times 7.7 . C\end{array}$ & $\begin{array}{l}237 \\
264 \\
296\end{array}$ & $\begin{array}{l}295 \\
301 \\
296\end{array}$ & $\begin{array}{l}260 \\
297 \\
278\end{array}$ & $\begin{array}{l}264 \pm 29 \\
287 \pm 20 \\
290 \pm 10\end{array}$ \\
\hline $\begin{array}{l}M \times 7.8 \cdot A \\
M \times 7.8-B \\
M \times 7.8-C\end{array}$ & $\begin{array}{l}449 \\
456 \\
454\end{array}$ & $\begin{array}{l}464 \\
482 \\
407\end{array}$ & $\begin{array}{l}453 \\
456 \\
427\end{array}$ & $\begin{array}{l}455 \neq 8 \\
465 \pm 15 \\
429 \pm 24\end{array}$ \\
\hline $\begin{array}{l}\text { MX7.9. A } \\
\text { MX7.9.B } \\
\text { MX7.9.C }\end{array}$ & $\begin{array}{l}378 \\
336 \\
340 \\
\end{array}$ & $\begin{array}{l}365 \\
321 \\
318 \\
\end{array}$ & $\begin{array}{l}339 \\
327 \\
307 \\
\end{array}$ & $\begin{aligned} & 361 \pm 20 \\
& 328 \pm 8 \\
& 322 \pm 17 \\
&\end{aligned}$ \\
\hline
\end{tabular}

"Average value and one standard deviation. 
Table F.9. Unconfined compressive-strength values for grouts prepared from Matrix 8

\begin{tabular}{|c|c|c|c|c|}
\hline \multirow{2}{*}{$\begin{array}{c}\begin{array}{c}\text { Run } \\
\text { No. }\end{array} \\
\text { MX8-1-A } \\
\text { MX8-1-B } \\
\text { MX8-1-C }\end{array}$} & \multicolumn{3}{|c|}{$\begin{array}{l}\text { Unconfined compressive strength } \\
\text { (psi) }\end{array}$} & \multirow{2}{*}{$\begin{array}{c}\text { Avernge } \\
416 \pm 26 \\
452 \pm 73 \\
486 \pm 39\end{array}$} \\
\hline & $\begin{array}{l}388 \\
418 \\
503\end{array}$ & $\begin{array}{l}416 \\
402 \\
513\end{array}$ & $\begin{array}{l}441 \\
535 \\
441\end{array}$ & \\
\hline $\begin{array}{l}\text { MX8-2-A } \\
\text { MX8-2.B } \\
\text { MX8-2.C }\end{array}$ & $\begin{array}{l}414 \\
390 \\
381\end{array}$ & $\begin{array}{l}386 \\
444 \\
442\end{array}$ & $\begin{array}{l}406 \\
486 \\
437\end{array}$ & $\begin{array}{l}402 \pm 15 \\
440 \pm 48 \\
420 \pm 34\end{array}$ \\
\hline $\begin{array}{l}\text { MX8-3-A } \\
M X 8-3-B \\
M X 8-3-C\end{array}$ & $\begin{array}{l}402 \\
386 \\
394\end{array}$ & $\begin{array}{l}443 \\
459 \\
395\end{array}$ & $\begin{array}{l}378 \\
394 \\
380\end{array}$ & $\begin{array}{l}407 \pm 33 \\
413 \pm 40 \\
390 \pm 8\end{array}$ \\
\hline $\begin{array}{l}M \times 8-4-A \\
M \times 8-4-B \\
M \times 8-4-C\end{array}$ & $\begin{array}{l}343 \\
352 \\
466\end{array}$ & $\begin{array}{l}356 \\
397 \\
379\end{array}$ & $\begin{array}{l}354 \\
416 \\
467\end{array}$ & $\begin{array}{l}351 \pm 7 \\
388 \pm 33 \\
437 \pm 50\end{array}$ \\
\hline $\begin{array}{l}\text { MX8.5.A } \\
\text { MX8.5-B } \\
\text { MX8-5-C }\end{array}$ & $\begin{array}{l}311 \\
330 \\
306\end{array}$ & $\begin{array}{l}302 \\
265 \\
296\end{array}$ & $\begin{array}{l}291 \\
321 \\
255\end{array}$ & $\begin{array}{l}301 \pm 10 \\
305 \pm 35 \\
286 \pm 27\end{array}$ \\
\hline $\begin{array}{l}M \times 8-6-A \\
M \times 8-6-B \\
M X 8-6-C\end{array}$ & $\begin{array}{l}209 \\
272 \\
247\end{array}$ & $\begin{array}{l}229 \\
287 \\
213\end{array}$ & $\begin{array}{l}206 \\
246 \\
198\end{array}$ & $\begin{array}{l}215 \pm 13 \\
268 \pm 21 \\
220 \pm 25\end{array}$ \\
\hline $\begin{array}{l}\text { MX8.7-A } \\
\text { MX8.7.B } \\
M X 8.7 . C\end{array}$ & $\begin{array}{l}274 \\
333 \\
319\end{array}$ & $\begin{array}{l}272 \\
336 \\
365\end{array}$ & $\begin{array}{l}273 \\
351 \\
313\end{array}$ & $\begin{array}{l}273 \pm 1 \\
340 \pm 10 \\
332 \pm 29\end{array}$ \\
\hline $\begin{array}{l}\text { MX8-8.A } \\
\text { MX8-8.B } \\
M X 8-8-C\end{array}$ & $\begin{array}{l}566 \\
483 \\
411\end{array}$ & $\begin{array}{l}551 \\
510 \\
436\end{array}$ & $\begin{array}{l}515 \\
482 \\
446\end{array}$ & $\begin{array}{l}544 \pm 26 \\
491 \pm 16 \\
431 \pm 18\end{array}$ \\
\hline $\begin{array}{l}\text { MX8.9.A } \\
\text { MX8.9-B } \\
\text { MX8-9.C }\end{array}$ & $\begin{array}{l}468 \\
458 \\
375\end{array}$ & $\begin{array}{l}541 \\
487 \\
453\end{array}$ & $\begin{array}{c}b \\
522 \\
452\end{array}$ & $\begin{array}{l}504 \\
489 \pm 32 \\
427 \pm 45\end{array}$ \\
\hline
\end{tabular}

Average value and one standard deviation.

'Sample cracked. 
Table F-10. Unconfined compressive-strength values for grouts prepared from Matrix 9

\begin{tabular}{|c|c|c|c|c|}
\hline \multirow{2}{*}{$\begin{array}{l}\begin{array}{c}\text { Run } \\
\text { No. }\end{array} \\
\text { MX9-1.A } \\
\text { MX9-1-B } \\
\text { MX9-1.C }\end{array}$} & \multicolumn{3}{|c|}{$\begin{array}{l}\text { Unconfined compressive strength } \\
\text { (psi) }\end{array}$} & \multirow{2}{*}{$\begin{array}{l}\text { Average } \\
364 \pm 40 \\
399 \pm 20 \\
661 \pm 45\end{array}$} \\
\hline & $\begin{array}{l}322 \\
377 \\
678\end{array}$ & $\begin{array}{l}402 \\
404 \\
610\end{array}$ & $\begin{array}{l}367 \\
417 \\
694\end{array}$ & \\
\hline $\begin{array}{l}M X 9.2 \cdot A \\
M X 9.2 \cdot B \\
M X 9-2 \cdot C\end{array}$ & $\begin{array}{l}470 \\
425 \\
344\end{array}$ & $\begin{array}{l}435 \\
414 \\
388\end{array}$ & $\begin{array}{l}436 \\
422 \\
416\end{array}$ & $\begin{array}{l}447 \pm 20 \\
420 \pm 5.6 \\
383 \pm 36\end{array}$ \\
\hline $\begin{array}{l}\text { MX9.3.A } \\
\text { MX9-3.B } \\
M X 9.3-C\end{array}$ & $\begin{array}{l}473 \\
315 \\
261\end{array}$ & $\begin{array}{l}447 \\
282 \\
373\end{array}$ & $\begin{array}{l}482 \\
324 \\
303\end{array}$ & $\begin{array}{l}467 \pm 18 \\
307 \pm 22 \\
313 \pm 57\end{array}$ \\
\hline $\begin{array}{l}M X 9-4 . A \\
M X 9-4-B \\
M X 9-4 . C\end{array}$ & $\begin{array}{l}368 \\
399 \\
353\end{array}$ & $\begin{array}{l}397 \\
445 \\
404\end{array}$ & $\begin{array}{l}314 \\
425 \\
383\end{array}$ & $\begin{array}{l}360 \pm 42 \\
423 \pm 23 \\
380 \pm 26\end{array}$ \\
\hline $\begin{array}{l}M \times 9.5 . A \\
M X 9.5 . B \\
M X 9.5 . C\end{array}$ & $\begin{array}{l}359 \\
373 \\
431\end{array}$ & $\begin{array}{l}347 \\
342 \\
341\end{array}$ & $\begin{array}{l}347 \\
355 \\
409\end{array}$ & $\begin{array}{l}351 \pm 7 \\
356 \pm 16 \\
394 \pm 47\end{array}$ \\
\hline $\begin{array}{l}M \times 9-6-A \\
M X 9-6-B \\
M X 9-6-C\end{array}$ & $\begin{array}{l}290 \\
393 \\
417\end{array}$ & $\begin{array}{l}421 \\
413 \\
428\end{array}$ & $\begin{array}{l}341 \\
420 \\
415\end{array}$ & $\begin{array}{l}350 \pm 66 \\
409 \pm 14 \\
420 \pm 7\end{array}$ \\
\hline $\begin{array}{l}M X 9.7 . A \\
M X 9.7-B \\
M X 9.7 . C\end{array}$ & $\begin{array}{l}481 \\
456 \\
462\end{array}$ & $\begin{array}{l}483 \\
428 \\
422\end{array}$ & $\begin{array}{l}430 \\
432 \\
437\end{array}$ & $\begin{array}{l}464 \pm 30 \\
438 \pm 15 \\
440 \pm 20\end{array}$ \\
\hline $\begin{array}{l}\text { MX9.8-A } \\
M X 9-8 . B \\
M X 9.8-C\end{array}$ & $\begin{array}{l}297 \\
221 \\
259\end{array}$ & $\begin{array}{l}299 \\
273 \\
222\end{array}$ & $\begin{array}{l}301 \\
281 \\
b\end{array}$ & $\begin{array}{l}299 \pm 2 \\
258 \pm 33 \\
240\end{array}$ \\
\hline $\begin{array}{l}\text { MX9.9.A } \\
\text { MX9.9.B } \\
\text { MX9.9.C }\end{array}$ & $\begin{array}{l}390 \\
379 \\
326\end{array}$ & $\begin{array}{l}390 \\
392 \\
375\end{array}$ & $\begin{array}{l}367 \\
354 \\
348\end{array}$ & $\begin{array}{l}383 \pm 12 \\
375 \pm 19 \\
350 \pm 24\end{array}$ \\
\hline
\end{tabular}

"Average value and one standard deviation.

bample cracked. 
Table F-11. Unconfined compressive-strength values for grouts prepared from Matrix 10

\begin{tabular}{|c|c|c|c|c|}
\hline \multirow{2}{*}{$\begin{array}{c}\begin{array}{c}\text { Run } \\
\text { No. }\end{array} \\
\text { MX9-1-A } \\
\text { MX9-1-B } \\
\text { MX9-1-C }\end{array}$} & \multicolumn{3}{|c|}{$\begin{array}{l}\text { Unconfined compressive strength } \\
(\mathrm{psi})\end{array}$} & \multirow{2}{*}{$\begin{array}{l}\text { Average }^{\mathrm{a}} \\
407 \pm 17 \\
350 \pm 56 \\
374 \pm 80\end{array}$} \\
\hline & $\begin{array}{l}388 \\
371 \\
372\end{array}$ & $\begin{array}{l}421 \\
287 \\
454\end{array}$ & $\begin{array}{l}412 \\
393 \\
295\end{array}$ & \\
\hline $\begin{array}{l}\text { MX9-2-A } \\
\text { MX9-2-B } \\
\text { MX9-2-C }\end{array}$ & $\begin{array}{l}421 \\
446 \\
362\end{array}$ & $\begin{array}{l}439 \\
441 \\
320\end{array}$ & $\begin{array}{l}465 \\
394 \\
400\end{array}$ & $\begin{array}{l}442 \pm 22 \\
427 \pm 28 \\
361 \pm 40\end{array}$ \\
\hline $\begin{array}{l}\text { MX9-3-A } \\
\text { MX9-3-B } \\
\text { MX9-3-C }\end{array}$ & $\begin{array}{l}440 \\
374 \\
435\end{array}$ & $\begin{array}{l}413 \\
416 \\
409\end{array}$ & $\begin{array}{c}414 \\
398 \\
b\end{array}$ & $\begin{array}{l}422 \pm 15 \\
396 \pm 21 \\
422\end{array}$ \\
\hline $\begin{array}{l}\text { MX9-4-A } \\
M X 9-4-B \\
M \times 9-4-C\end{array}$ & $\begin{array}{l}441 \\
500 \\
402\end{array}$ & $\begin{array}{l}465 \\
485 \\
415\end{array}$ & $\begin{array}{l}389 \\
451 \\
401\end{array}$ & $\begin{array}{l}432 \pm 39 \\
478 \pm 25 \\
406 \pm 8\end{array}$ \\
\hline $\begin{array}{l}\text { MX9-5-A } \\
\text { MX9-5-B } \\
\text { MX9-5-C }\end{array}$ & $\begin{array}{l}357 \\
322 \\
334\end{array}$ & $\begin{array}{l}378 \\
308 \\
320\end{array}$ & $\begin{array}{l}326 \\
289 \\
b\end{array}$ & $\begin{array}{l}354 \pm 26 \\
306 \pm 16 \\
327\end{array}$ \\
\hline $\begin{array}{l}\text { MX9-6-A } \\
\text { MX9-6-B } \\
\text { MX9-6-C }\end{array}$ & $\begin{array}{l}306 \\
382 \\
315\end{array}$ & $\begin{array}{l}286 \\
434 \\
326\end{array}$ & $\begin{array}{l}296 \\
455 \\
377\end{array}$ & $\begin{array}{l}296 \pm 10 \\
424 \pm 38 \\
339 \pm 33\end{array}$ \\
\hline $\begin{array}{l}\text { MX9-7-A } \\
M X 9-7-B \\
M X 9-7-C\end{array}$ & $\begin{array}{l}453 \\
545 \\
508\end{array}$ & $\begin{array}{l}533 \\
592 \\
528\end{array}$ & $\begin{array}{l}451 \\
489 \\
497\end{array}$ & $\begin{array}{l}479 \pm 47 \\
542 \pm 52 \\
511 \pm 15\end{array}$ \\
\hline $\begin{array}{l}\text { MX9-8-A } \\
\text { MX9-8-B } \\
\text { MX9-8-C }\end{array}$ & $\begin{array}{l}637 \\
659 \\
714\end{array}$ & $\begin{array}{l}626 \\
691 \\
721\end{array}$ & $\begin{array}{l}669 \\
675 \\
671\end{array}$ & $\begin{array}{l}644 \pm 22 \\
675 \pm 16 \\
702 \pm 27\end{array}$ \\
\hline $\begin{array}{l}\text { MX9-9-A } \\
\text { MX9-9-B } \\
\text { MX9-9-C }\end{array}$ & $\begin{array}{l}317 \\
405 \\
376\end{array}$ & $\begin{array}{l}302 \\
402 \\
398\end{array}$ & $\begin{array}{l}354 \\
399 \\
390\end{array}$ & $\begin{array}{l}324 \pm 27 \\
402 \pm 3 \\
388 \pm 11\end{array}$ \\
\hline
\end{tabular}

"Average value and one standard deviation.

bample cracked. 
Table F-12. Unconfined compressive-strength values for grouts prepared from Matrix 11

\begin{tabular}{|c|c|c|c|c|}
\hline \multirow{2}{*}{$\begin{array}{l}\begin{array}{l}\text { Run } \\
\text { No. }\end{array} \\
\text { MX11-1-A }\end{array}$} & \multicolumn{3}{|c|}{$\begin{array}{l}\text { Unconfined compressive strength } \\
\text { (psi) }\end{array}$} & \multirow{2}{*}{$\frac{\text { Average }^{\mathrm{a}}}{603 \pm 42}$} \\
\hline & 587 & 651 & 572 & \\
\hline MX11-1-B & 449 & 484 & 486 & $473 \pm 21$ \\
\hline$M X 11-1-C$ & 473 & 461 & 428 & $454 \pm 24$ \\
\hline$M \times 11-2-A$ & 575 & 632 & 607 & $605 \pm 29$ \\
\hline$M X 11-2-B$ & 724 & 646 & 717 & $696 \pm 43$ \\
\hline MX11-2-C & 617 & 708 & 684 & $670 \pm 47$ \\
\hline$M X 11-3-A$ & 580 & 564 & 558 & $567 \pm 11$ \\
\hline MX11-3-B & 680 & 685 & 670 & $678 \pm 8$ \\
\hline MX11-3-C & 671 & 627 & 524 & $608 \pm 76$ \\
\hline $\mathrm{MX} 11-4-\mathrm{A}$ & 327 & 423 & 356 & $369 \pm 50$ \\
\hline MX11-4-B & 423 & 424 & 383 & $410 \pm 23$ \\
\hline$M X 11-4-C$ & 303 & 366 & 371 & $347 \pm 37$ \\
\hline MX11-5-A & 355 & 349 & 322 & $342 \pm 17$ \\
\hline$M X 11-5-B$ & 382 & 390 & 385 & $385 \pm 4$ \\
\hline $\mathrm{MX} 11-5 \cdot \mathrm{C}$ & 413 & 391 & 321 & $375 \pm 48$ \\
\hline$M X 11-6-A$ & 370 & 373 & 353 & $365 \pm 11$ \\
\hline $\mathrm{MX} 11-6-\mathrm{B}$ & 403 & 476 & 350 & $410 \pm 63$ \\
\hline$M X 11-6-C$ & 282 & 472 & 392 & $382 \pm 95$ \\
\hline$M X 11-7-A$ & 792 & 859 & 857 & $836 \pm 38$ \\
\hline$M X 11-7-B$ & 801 & 830 & 865 & $832 \pm 32$ \\
\hline$M \times 11-7-C$ & 778 & 820 & 850 & $816 \pm 36$ \\
\hline MX11-8-A & 802 & 802 & 742 & $782 \pm 35$ \\
\hline MX11-8-B & 812 & 857 & 761 & $810 \pm 48$ \\
\hline $\mathrm{MX} 11-8-\mathrm{C}$ & 913 & 897 & 868 & $893 \pm 23$ \\
\hline MX11-9-A & 620 & 582 & 564 & $589 \pm 28$ \\
\hline MX11-9-B & 522 & 622 & 554 & $566 \pm 51$ \\
\hline MX11-9-C & 790 & 721 & 832 & $781 \pm 56$ \\
\hline
\end{tabular}

${ }^{2}$ Average value and one standard deviation. 
Table F-13. Unconfined compressive-strength values for grouts prepared from Matrix 12

\begin{tabular}{|c|c|c|c|c|}
\hline \multirow{2}{*}{$\begin{array}{l}\begin{array}{c}\text { Run } \\
\text { No. }\end{array} \\
\text { MX12-1-A } \\
\text { MX12-1-B } \\
\text { MX12-1-C }\end{array}$} & \multicolumn{3}{|c|}{$\begin{array}{l}\text { Unconfined compressive strength } \\
\text { (psi) }\end{array}$} & \multirow{2}{*}{$\begin{array}{l}\text { Average } \\
550 \pm 24 \\
571 \\
545 \pm 86\end{array}$} \\
\hline & $\begin{array}{l}529 \\
580 \\
447\end{array}$ & $\begin{array}{l}577 \\
561 \\
583\end{array}$ & $\begin{array}{c}546 \\
b \\
606\end{array}$ & \\
\hline $\begin{array}{l}M \times 12-2-A \\
M X 12-2-B \\
M X 12-2-C\end{array}$ & $\begin{array}{l}484 \\
445 \\
513\end{array}$ & $\begin{array}{l}526 \\
619 \\
561\end{array}$ & $\begin{array}{l}493 \\
507 \\
506\end{array}$ & $\begin{array}{l}501 \pm 22 \\
524 \pm 88 \\
527 \pm 30\end{array}$ \\
\hline $\begin{array}{l}M X 12-3-A \\
M X 12-3-B \\
M X 12-3-C\end{array}$ & $\begin{array}{l}572 \\
412 \\
465\end{array}$ & $\begin{array}{l}543 \\
493 \\
475\end{array}$ & $\begin{array}{l}514 \\
479 \\
497\end{array}$ & $\begin{array}{l}543 \pm 29 \\
461 \pm 43 \\
479 \pm 16\end{array}$ \\
\hline $\begin{array}{l}\text { MX12-4-A } \\
\text { MX12-4-B } \\
\text { MX12-4-C }\end{array}$ & $\begin{array}{l}486 \\
433 \\
515\end{array}$ & $\begin{array}{l}483 \\
489 \\
555\end{array}$ & $\begin{array}{l}490 \\
454 \\
513\end{array}$ & $\begin{array}{l}486 \pm 4 \\
459 \pm 28 \\
528 \pm 24\end{array}$ \\
\hline $\begin{array}{l}M X 12-5-A \\
M X 12-5-B \\
M X 12-5-C\end{array}$ & $\begin{array}{l}580 \\
614 \\
515\end{array}$ & $\begin{array}{l}635 \\
728 \\
462\end{array}$ & $\begin{array}{l}568 \\
635 \\
632\end{array}$ & $\begin{array}{l}594 \pm 36 \\
659 \pm 61 \\
536 \pm 87\end{array}$ \\
\hline $\begin{array}{l}M X 12-6-A \\
M X 12-6-B \\
M X 12-6-C\end{array}$ & $\begin{array}{l}609 \\
585 \\
570\end{array}$ & $\begin{array}{l}647 \\
676 \\
530\end{array}$ & $\begin{array}{l}544 \\
550 \\
568\end{array}$ & $\begin{array}{l}600 \pm 52 \\
590 \pm 43 \\
556 \pm 22\end{array}$ \\
\hline $\begin{array}{l}M X 12-7-A \\
M X 12-7-B \\
M X 12-7-C\end{array}$ & $\begin{array}{l}670 \\
609 \\
611\end{array}$ & $\begin{array}{l}544 \\
603 \\
533\end{array}$ & $\begin{array}{l}b \\
640 \\
614\end{array}$ & $\begin{array}{l}607 \\
617 \pm 20 \\
586 \pm 46\end{array}$ \\
\hline $\begin{array}{l}M X 12-8-A \\
M X 12-8-B \\
M X 12-8-C\end{array}$ & $\begin{array}{l}457 \\
414 \\
417\end{array}$ & $\begin{array}{l}389 \\
448 \\
428\end{array}$ & $\begin{array}{l}404 \\
439 \\
416\end{array}$ & $\begin{array}{l}417 \pm 36 \\
433 \pm 18 \\
420 \pm 7\end{array}$ \\
\hline $\begin{array}{l}\text { MX12-9-A } \\
\text { MX12-9-B } \\
\text { MX12-9-C }\end{array}$ & $\begin{array}{l}b \\
493 \\
481\end{array}$ & $\begin{array}{l}525 \\
518 \\
495\end{array}$ & $\begin{array}{l}477 \\
480 \\
435\end{array}$ & $\begin{array}{l}501 \\
497 \pm 19 \\
470 \pm 31\end{array}$ \\
\hline
\end{tabular}

${ }^{2}$ Average value and one standard deviation.

bample cracked. 
Table F-14. Unconfined compressive-strength values for grouts prepared from Matrix 13

\begin{tabular}{|c|c|c|c|c|}
\hline \multirow{2}{*}{$\begin{array}{l}\begin{array}{c}\text { Run } \\
\text { No. }\end{array} \\
\text { MX13-1-A } \\
\text { MX13-1-B } \\
\text { MX13-1.C }\end{array}$} & \multicolumn{3}{|c|}{$\begin{array}{l}\text { Unconfined compressive strength } \\
\text { (psi) }\end{array}$} & \multirow{2}{*}{$\begin{array}{l}\text { Average } \\
567 \pm 40 \\
503 \pm 32 \\
380 \pm 13\end{array}$} \\
\hline & $\begin{array}{l}610 \\
539 \\
383\end{array}$ & $\begin{array}{l}559 \\
484 \\
367\end{array}$ & $\begin{array}{l}532 \\
485 \\
393\end{array}$ & \\
\hline $\begin{array}{l}M X 13-2-A \\
M X 13-2-B \\
M X 13-2-C\end{array}$ & $\begin{array}{l}484 \\
484 \\
541\end{array}$ & $\begin{array}{l}464 \\
592 \\
511\end{array}$ & $\begin{array}{l}518 \\
549 \\
580\end{array}$ & $\begin{array}{l}489 \pm 27 \\
542 \pm 55 \\
544 \pm 35\end{array}$ \\
\hline $\begin{array}{l}M X 13-3-A \\
M X 13-3-B \\
M X 13-3-C\end{array}$ & $\begin{array}{l}427 \\
542 \\
379\end{array}$ & $\begin{array}{l}392 \\
499 \\
438\end{array}$ & $\begin{array}{l}417 \\
497 \\
427\end{array}$ & $\begin{array}{l}412 \pm 18 \\
513 \pm 25 \\
415 \pm 31\end{array}$ \\
\hline $\begin{array}{l}M X 13-4-A \\
M X 13-4-B \\
M X 13-4-C\end{array}$ & $\begin{array}{l}644 \\
545 \\
630\end{array}$ & $\begin{array}{l}686 \\
523 \\
689\end{array}$ & $\begin{array}{l}625 \\
538 \\
610\end{array}$ & $\begin{array}{l}652 \pm 31 \\
535 \pm 11 \\
643 \pm 41\end{array}$ \\
\hline $\begin{array}{l}M X 13-5-A \\
M X 13-5-B \\
M X 13-5-C\end{array}$ & $\begin{array}{l}469 \\
475 \\
490\end{array}$ & $\begin{array}{l}522 \\
486 \\
476\end{array}$ & $\begin{array}{l}473 \\
473 \\
456\end{array}$ & $\begin{array}{l}488 \pm 30 \\
478 \pm 7 \\
474 \pm 17\end{array}$ \\
\hline $\begin{array}{l}M X 13-6-A \\
M X 13-6-B \\
M X 13-6-C\end{array}$ & $\begin{array}{l}478 \\
447 \\
490\end{array}$ & $\begin{array}{l}506 \\
536 \\
470\end{array}$ & $\begin{array}{l}592 \\
478 \\
477\end{array}$ & $\begin{array}{l}525 \pm 59 \\
487 \pm 45 \\
479 \pm 10\end{array}$ \\
\hline $\begin{array}{l}\text { MX13-7-A } \\
M X 13-7-B \\
M X 13-7-C\end{array}$ & $\begin{array}{l}530 \\
549 \\
468\end{array}$ & $\begin{array}{l}529 \\
511 \\
448\end{array}$ & $\begin{array}{l}526 \\
561 \\
475\end{array}$ & $\begin{array}{l}528 \pm 2 \\
540 \pm 26 \\
463 \pm 14\end{array}$ \\
\hline $\begin{array}{l}\text { MX13-8-A } \\
M X 13-8-B \\
M X 13-8-C\end{array}$ & $\begin{array}{l}457 \\
484 \\
406\end{array}$ & $\begin{array}{l}445 \\
447 \\
423\end{array}$ & $\begin{array}{l}439 \\
409 \\
387\end{array}$ & $\begin{array}{l}447 \pm 10 \\
447 \pm 37 \\
405 \pm 18\end{array}$ \\
\hline $\begin{array}{l}\text { MX13-9-A } \\
M X 13-9-B \\
M X 13-9 . C\end{array}$ & $\begin{array}{l}483 \\
506 \\
400\end{array}$ & $\begin{array}{l}443 \\
438 \\
384\end{array}$ & $\begin{array}{l}401 \\
457 \\
409\end{array}$ & $\begin{array}{l}442 \pm 41 \\
467 \pm 35 \\
397 \pm 13\end{array}$ \\
\hline
\end{tabular}

Average value and one standard deviation. 
Appendix G. AVERAGED FLUID-PROPERTY DATA

$-$ 
Table G-1. Summary of properties' for fluid grout prepared from Matrix 1

\begin{tabular}{cccccc}
\hline $\begin{array}{c}\text { Run } \\
\text { No. }\end{array}$ & $\begin{array}{c}\text { Critical } \\
\text { velocity } \\
(\mathrm{gal} / \mathrm{min})\end{array}$ & $\begin{array}{c}\text { Frictional } \\
\text { pressure } \\
\text { drop } \\
(\mathrm{ps} / 100 \mathrm{ft})\end{array}$ & $\begin{array}{c}\text { Pump- } \\
\text { head } \\
\text { pressure } \\
(\mathrm{psi})\end{array}$ & $\begin{array}{c}\text { 10-min gel } \\
\text { strength } \\
\left(\mathrm{lb} / 100 \mathrm{ft}^{2}\right)\end{array}$ & $\begin{array}{c}\text { Density } \\
(\mathrm{lb} / \mathrm{gal})\end{array}$ \\
\hline MX1-1 & $14.8 \pm 0.1$ & $5.7 \pm 0.1$ & $2.1 \pm 0.3$ & $5.8 \pm 0.8$ & $13.5 \pm 0.1$ \\
MX1-2 & $15.5 \pm 0.4$ & $5.7 \pm 0$ & $3.2 \pm 0.3$ & $8.7 \pm 0.7$ & $13.5 \pm 0$ \\
MX1-3 & $15.4 \pm 4$ & $5.5 \pm 0$ & $2.5 \pm 0.1$ & $6.8 \pm 0.3$ & $13.2 \pm 0$ \\
MX1-4 & $14.8 \pm 0.7$ & $5.6 \pm 0$ & $2.5 \pm 0.1$ & $6.9 \pm 0.1$ & $13.3 \pm 0.1$ \\
MX1-5 & $13.1 \pm 0.7$ & $5.5 \pm 0$ & $1.7 \pm 0.2$ & $4.7 \pm 0.4$ & $13.2 \pm 0$ \\
MX1-6 & $15.3 \pm 0.3$ & $5.7 \pm 0$ & $2.3 \pm 0.2$ & $6.2 \pm 0.6$ & $13.5 \pm 0$ \\
MX1.7 & $13.3 \pm 0.2$ & $5.5 \pm 0.1$ & $2.1 \pm 0.2$ & $5.8 \pm 0.6$ & $13.2 \pm 0$ \\
MX1-8 & $14.2 \pm 0.8$ & $5.6 \pm 0$ & $2.3 \pm 0.2$ & $6.2 \pm 0.4$ & $13.3 \pm 0.1$ \\
MX1-9 & $13.3 \pm 0.6$ & $5.6 \pm 0$ & $17.7 \pm 15$ & $48.5 \pm 42$ & $13.3 \pm 0$ \\
& & & & & \\
Average & $14.6 \pm 1.5$ & $5.6 \pm 0$ & $2.3 \pm 0.4$ & $6.4 \pm 1.2$ & $13.3 \pm 0.1$ \\
\hline
\end{tabular}

Average values and one standard deviation obtained from three replicates.

${ }^{b}$ Average values and one standard deviation obtained from all data except run MX1-9. 
Table G-2. Summary of properties' for fluid grout prepared from Matrix 2

\begin{tabular}{cccccc}
\hline $\begin{array}{c}\text { Run } \\
\text { No. }\end{array}$ & $\begin{array}{c}\text { Critical } \\
\text { velocity } \\
(\mathrm{gal} / \mathrm{min})\end{array}$ & $\begin{array}{c}\text { Frictional } \\
\text { pressure } \\
\text { drop } \\
(\mathrm{psi} / 100 \mathrm{ft})\end{array}$ & $\begin{array}{c}\text { Pump- } \\
\text { head } \\
\text { pressure } \\
(\mathrm{psi})\end{array}$ & $\begin{array}{c}\text { 10-min gel } \\
\text { strength } \\
\left(\mathrm{lb} / 100 \mathrm{ft}^{2}\right)\end{array}$ & $\begin{array}{c}\text { Density } \\
(\mathrm{lb} / \mathrm{gal})\end{array}$ \\
\hline MX2-1 & $13.3 \pm 0.6$ & $5.7 \pm 0$ & $2.3 \pm 0.1$ & $6.3 \pm 0.3$ & $13.6 \pm 0$ \\
MX2.2 & $11.9 \pm 0.1$ & $5.6 \pm 0$ & $2.0 \pm 0.3$ & $5.5 \pm 0.9$ & $13.3 \pm 0$ \\
MX2.3 & $12.3 \pm 0.1$ & $5.6 \pm 0$ & $2.6 \pm 0.1$ & $7.2 \pm 0.3$ & $13.3 \pm 0.1$ \\
MX2-4 & $14.3 \pm 0.3$ & $5.7 \pm 0$ & $4.2 \pm 0.2$ & $11.5 \pm 0.5$ & $13.6 \pm 0$ \\
MX2.5 & $13.9 \pm 0.6$ & $5.7 \pm 0$ & $3.9 \pm 0.9$ & $10.8 \pm 2.5$ & $13.5 \pm 0$ \\
MX2.6 & $12.8 \pm 0.6$ & $5.6 \pm 0$ & $1.6 \pm 0.2$ & $4.6 \pm 0.4$ & $13.3 \pm 0.1$ \\
MX2-7 & $14.4 \pm 0.4$ & $5.7 \pm 0$ & $2.3 \pm 0.3$ & $6.2 \pm 0.8$ & $13.6 \pm 0$ \\
MX2-8 & $13.7 \pm 0.3$ & $5.6 \pm 0.1$ & $3.7 \pm 0.5$ & $10.1 \pm 1.2$ & $13.4 \pm 0.1$ \\
MX2.9 & $15.8 \pm 0.2$ & $5.8 \pm 0.1$ & $5.8 \pm 0$ & $16.8 \pm 2.0$ & $13.7 \pm 0$ \\
& & & & & \\
Average & $13.6 \pm 1.2$ & $5.7 \pm 0.1$ & $3.2 \pm 1.3$ & $8.9 \pm 3.9$ & $13.5 \pm 0.2$ \\
\hline
\end{tabular}

-Average values and one standard deviation obtained from three replicates.

'Average values and one standard deviation obtained from all data. 
Table G-3. Summary of properties" for fluld grout prepared from Matrix $2 R$

\begin{tabular}{lccccl}
\hline $\begin{array}{c}\text { Run } \\
\text { No. }\end{array}$ & $\begin{array}{c}\text { Critical } \\
\text { velocity } \\
(\mathrm{gal} / \mathrm{min})\end{array}$ & $\begin{array}{c}\text { Frictional } \\
\text { pressure } \\
\text { drop } \\
(\mathrm{psi} / 100 \mathrm{ft})\end{array}$ & $\begin{array}{c}\text { Pump- } \\
\text { head } \\
\text { pressure } \\
(\mathrm{psi})\end{array}$ & $\begin{array}{c}\text { 10-min gel } \\
\text { strength } \\
\left(\mathrm{lb} / 100 \mathrm{ft}^{2}\right)\end{array}$ & $\begin{array}{c}\text { Density } \\
(\mathrm{lb} / \mathrm{gal})\end{array}$ \\
\hline MX2R-1 & $14.3 \pm 0.2$ & $5.6 \pm 0$ & $1.5 \pm 0.2$ & $4.2 \pm 0.6$ & $13.4 \pm 0$ \\
MX2R-2 & $11.9 \pm 0.6$ & $5.5 \pm 0$ & $1.3 \pm 0$ & $3.5 \pm 0$ & $13.1 \pm 0$ \\
MX2R-3 & $12.2 \pm 0.6$ & $5.5 \pm 0$ & $1.2 \pm 0.1$ & $3.2 \pm 0.3$ & $13.0 \pm 0.1$ \\
MX2R-4 & $15.0 \pm 0.1$ & $5.6 \pm 0$ & $1.8 \pm 0.2$ & $5.0 \pm 0.5$ & $13.4 \pm 0$ \\
MX2R-5 & $14.1 \pm 0.5$ & $5.6 \pm 0.1$ & $1.3 \pm 0$ & $3.5 \pm 0$ & $13.2 \pm 0$ \\
MX2R-6 & $13.2 \pm 1.1$ & $5.5 \pm 0$ & $1.2 \pm 0.1$ & $3.3 \pm 0.3$ & $13.0 \pm 0$ \\
MX2R-7 & $14.8 \pm 0.5$ & $5.6 \pm 0$ & $1.7 \pm 0.1$ & $4.7 \pm 0.3$ & $13.4 \pm 0$ \\
MX2R-8 & $13.0 \pm 0.5$ & $5.5 \pm 0$ & $1.3 \pm 0.2$ & $3.5 \pm 0.5$ & $13.1 \pm 0$ \\
MX2R-9 & $14.3 \pm 0.1$ & $5.6 \pm 0$ & $1.6 \pm 0.1$ & $4.3 \pm 0.3$ & $13.4 \pm 0$ \\
Average & $13.6 \pm 1.2$ & $5.6 \pm 0.1$ & $1.4 \pm 0.2$ & $3.9 \pm 0.7$ & $13.2 \pm 0.2$ \\
\hline
\end{tabular}

Average values and one standard deviation obtained from three replicates.

'Average values and one standard deviation obtained from all data. 
Table 0.4. Summary of properties" for nuld grout prepared from Matrix 3

\begin{tabular}{|c|c|c|c|c|c|}
\hline $\begin{array}{l}\text { Run } \\
\text { No. }\end{array}$ & $\begin{array}{c}\text { Critical } \\
\text { velocity } \\
\text { (gal/min) }\end{array}$ & $\begin{array}{l}\text { Frictional } \\
\text { pressure } \\
\text { drop } \\
\text { (psi/100 ft) }\end{array}$ & $\begin{array}{l}\text { Pump- } \\
\text { head } \\
\text { pressure } \\
\text { (psi) }\end{array}$ & $\begin{array}{l}\text { 10-min gel } \\
\text { strength } \\
\left(1 b_{f} / 100\left(t^{2}\right)\right.\end{array}$ & $\begin{array}{l}\text { Density } \\
\text { (lb/gal) }\end{array}$ \\
\hline $\begin{array}{l}M X 3.1 \\
M X 3.2 \\
M X 3.3 \\
M X 3.4 \\
M X 3.5 \\
M X 3.6 \\
M X 3.7 \\
M X 3.8 \\
M X 3.9\end{array}$ & $\begin{array}{l}15.2 \div 0.3 \\
14.1 \div 0.4 \\
15.0 \div 0.3 \\
13.5 \div 0.5 \\
16.0 \div 0.3 \\
17.0 \div 0.3 \\
14.5 \div 0.6 \\
14.6 \div 0.4 \\
14.8 \div 0.6\end{array}$ & $\begin{array}{l}5.7 \pm 0 \\
5.6 \pm 0 \\
5.7 \pm 0 \\
5.6 \pm 0 \\
5.7 \pm 0 \\
5.7 \pm 0 \\
5.6 \pm 0 \\
5.6 \pm 0 \\
5.7 \pm 0\end{array}$ & $\begin{array}{l}5.4 \pm 0.3 \\
4.7 \pm 0.4 \\
6.9 \pm 1.6 \\
4.6 \pm 0.9 \\
5.0 \pm 0.5 \\
8.7 \pm 0.5 \\
5.1 \neq 0.3 \\
6.8 \neq 1.2 \\
3.3 \pm 0.8\end{array}$ & $\begin{array}{l}14.8 \div 0.8 \\
13.0 \div 1.0 \\
18.8 \div 4.3 \\
12.5 \pm 2.3 \\
13.8 \pm 1.4 \\
23.8 \div 1.3 \\
14.0 \div 0.9 \\
18.5 \div 3.3 \\
9.0 \div 2.2\end{array}$ & $\begin{array}{l}13.6 \neq 0.166 \\
13.4 \neq 0 \\
13.6 \neq 0 \\
13.3 \neq 0 \\
13.5 \neq 0 \\
13.7 \neq 0 .(66 \\
13.3 \neq 0.06 \\
13.4 \neq 0 \\
13.5 \neq 0\end{array}$ \\
\hline Averageb $^{b}$ & $15.0 \pm 1.0$ & $5.7 \neq 0.05$ & $5.6 \neq 1.7$ & $15.4 \neq 4.6$ & $13.5 * 0.1$ \\
\hline
\end{tabular}

-Average values and one standard deviation obtained from three replicates.

bAverage values and one standard deviation obtained from all data. 
Table O.5. Summary of properties' for nuld grout prepared from Matrix 4

\begin{tabular}{|c|c|c|c|c|c|}
\hline $\begin{array}{l}\text { Run } \\
\text { No. }\end{array}$ & $\begin{array}{c}\text { Critical } \\
\text { velocity } \\
(\text { gal/min) }\end{array}$ & $\begin{array}{l}\text { Frictional } \\
\text { pressure } \\
\text { drop } \\
(\mathrm{ps} / / 100 \mathrm{n})\end{array}$ & $\begin{array}{l}\text { Pump. } \\
\text { head } \\
\text { pressure } \\
\text { (psi) }\end{array}$ & $\begin{array}{l}\text { 10-min gel } \\
\text { strength } \\
\left(16, / 100 \mathrm{f}^{2}\right)\end{array}$ & $\begin{array}{l}\text { Density } \\
\text { (lb/gal) }\end{array}$ \\
\hline $\begin{array}{l}M X 4.1 \\
M X 4-2 \\
M X 4.3 \\
M X 4.4 \\
M X 4.5 \\
M X 4.6 \\
M X 4.7 \\
M X 4.8 \\
M X 4.9\end{array}$ & $\begin{array}{l}14.7=0.2 \\
16.2: 0.3 \\
16.2=0.2 \\
16.6 \div 0.2 \\
14.3 \div 0.3 \\
13.1=0.5 \\
14.0 \div 0.4 \\
15.4 \div 0.3 \\
14.1 \div 0.06\end{array}$ & $\begin{array}{l}5.6 \neq 0 \\
5.7 \neq 0 \\
5.7 \neq 0 \\
5.7 \neq 0.06 \\
5.6 \neq 0 \\
5.6 \neq 0.06 \\
5.6 \pm 0 \\
5.7 \neq 0 \\
5.6 \pm 0\end{array}$ & $\begin{array}{l}2.3 \div 0.2 \\
2.3 \div 0.3 \\
2.2 \div 0.3 \\
2.3 \div 0.3 \\
1.6 \div 0 \\
1.5 \div 0.2 \\
1.6 \div 0 \\
2.3 \div 0.3 \\
2.1 \div 0.5\end{array}$ & $\begin{array}{l}6.3 \neq 0.6 \\
6.3 \neq 0.8 \\
6.0 \pm 0.9 \\
6.3 \neq 0.8 \\
4.5 \div 0 \\
4.0 \div 0.5 \\
4.5 \div 0 \\
6.2 \div 0.8 \\
5.7 \div 1.4\end{array}$ & $\begin{array}{l}1.3 .4=0.06 \\
13.6 \geq 0.06 \\
13.6 \geq 0 \\
13.5=0.06 \\
13.3 \geq 0 \\
13.2 \geq 0.06 \\
13.3 \geq 0.06 \\
13.5 \geq 0 \\
13.3 \geq 0.06\end{array}$ \\
\hline Averageb & $15.0 \div 1.2$ & $5.6 \pm 0.06$ & $2.0 \div 0.4$ & $5.5 \neq 1.1$ & $13.4 \div 0.1$ \\
\hline
\end{tabular}

Average values and one standard deviation obtained from three replicates.

Average values and one standard deviation obtained from all data. 
Table 0-6. Summary of properties" for fluld groul prepared from Matrix 5

\begin{tabular}{|c|c|c|c|c|c|}
\hline $\begin{array}{l}\text { Run } \\
\text { No. }\end{array}$ & $\begin{array}{c}\text { Critical } \\
\text { velocity } \\
(g a l / m i n)\end{array}$ & $\begin{array}{c}\text { Frictional } \\
\text { pressure } \\
\text { drop } \\
(\text { pavion } n)\end{array}$ & $\begin{array}{l}\text { Pump. } \\
\text { head } \\
\text { preasure } \\
\text { (pal) }\end{array}$ & $\begin{array}{l}\text { 10-min gel } \\
\text { strengeh } \\
\left(16,100 n^{2}\right)\end{array}$ & $\begin{array}{l}\text { Density } \\
\text { (lb/gal) }\end{array}$ \\
\hline $\begin{array}{l}\text { MX5.1 } \\
\text { MXS.-2 } \\
\text { MXS.3 } \\
\text { MX5.4 } \\
\text { MX5.5 } \\
\text { MX5.6 } \\
\text { MX5.7 } \\
\text { MX5.8 } \\
\text { MX5.9 }\end{array}$ & $\begin{array}{l}16.8 \div 0.06 \\
14.5 \div 0.4 \\
14.6 \div 0.3 \\
18.9 \div 0.9 \\
16.1 \div 0.4 \\
16.7 \div 0.3 \\
17.8 \div 0.4 \\
16.2 \div 0.2 \\
15.1 \div 0.3\end{array}$ & $\begin{array}{l}5.6 \neq 0 \\
5.5=0 \\
5.5 \neq 0 \\
5.5 \neq 0 \\
5.6=0 \\
5.6 \neq 0 \\
5.6 \neq 0 \\
5.6 \neq 0 \\
5.6 \neq 0\end{array}$ & $\begin{array}{l}2.1=0.3 \\
1.6 \div 0.06 \\
1.7=0.1 \\
1.6 \div 0.4 \\
2.1=0.1 \\
2.3: 0.2 \\
2.5: 0.1 \\
2.4: 0.2 \\
1.7=0.1\end{array}$ & $\begin{array}{l}5.7: 0.8 \\
4.3=0.3 \\
4.8 \div 0.3 \\
4.5: 1.0 \\
5.7: 0.3 \\
6.2: 0.6 \\
6.8=0.3 \\
6.5: 0.5 \\
4.8=0.3\end{array}$ & $\begin{array}{l}13.4: 0 \\
13.1=0 \\
13.1=0 \\
13.2: 0.06 \\
13.4: 0 \\
13.4=0 \\
13.4=0.06 \\
13.4: 0 \\
13.3: 0\end{array}$ \\
\hline Averageb $^{b}$ & $16.0 \div 1.1$ & $5.6 \neq 0.05$ & $2.0 \div 0.4$ & $5.5 * 1.0$ & $13.3 * 0.1$ \\
\hline
\end{tabular}

-Average values and use standard deviation obtained from three replicates.

-Average values and one standard deviation obtained from all data. 
Table 0.7. Summary of properties" for nuld grout prepared from Matrix 6

\begin{tabular}{|c|c|c|c|c|c|}
\hline $\begin{array}{l}\text { Run } \\
\text { No. }\end{array}$ & $\begin{array}{c}\text { Critical } \\
\text { velocity } \\
(\text { gal/min) }\end{array}$ & $\begin{array}{c}\text { Frictional } \\
\text { pressure } \\
\text { drop } \\
(\mathrm{ps} / / 100 \mathrm{n})\end{array}$ & $\begin{array}{l}\text { Pump. } \\
\text { head } \\
\text { pressure } \\
\text { (psl) }\end{array}$ & $\begin{array}{l}\text { 10-min gel } \\
\text { strength } \\
\left(16 / 100 \mathrm{n}^{2}\right)\end{array}$ & $\begin{array}{l}\text { Density } \\
\text { (Ib/gal) }\end{array}$ \\
\hline $\begin{array}{l}\text { MX6-1 } \\
M X 6-2 \\
M X 6-3 \\
M X 6-4 \\
M X 6-5 \\
M X 6-6 \\
M X 6-7 \\
M X 6-8 \\
M X 6-9\end{array}$ & $\begin{array}{l}17.9: 0.5 \\
15.9: 0.8 \\
18.5: 0.8 \\
17.9: 1.0 \\
14.8: 0.4 \\
14.5: 0.2 \\
16.1: 0.1 \\
15.1: 0.3 \\
16.5: 1.0\end{array}$ & $\begin{array}{l}5.6 \geq 0 \\
5.5 \geq 0 \\
5.6 \geq 0 \\
5.6 \geq 0 \\
5.5 \geq 0 \\
5.5 \geq 0 \\
5.6 \geq 0 \\
5.5 \geq 0 \\
5.6 \geq 0\end{array}$ & $\begin{array}{l}2.8: 0.3 \\
2.0: 0.4 \\
2.1: 0.3 \\
2.4: 0.2 \\
1.7: 0.3 \\
1.9: 0.3 \\
1.7: 0.1 \\
1.5: 0.2 \\
2.4: 0\end{array}$ & $\begin{array}{l}7.7: 0.7 \\
5.5: 1.0 \\
5.7: 0.8 \\
6.5: 0.5 \\
4.5: 0.9 \\
5.3: 0.8 \\
4.7: 0.3 \\
4.0: 0.5 \\
6.5: 0\end{array}$ & $\begin{array}{l}13.4=0 \\
13.1=0 \\
13.4=0 \\
13.3=0 \\
13.0=0 \\
13.1: 0 \\
13.2: 0.06 \\
13.2: 0 \\
13.4: 0\end{array}$ \\
\hline Averageb & $16.3 \div 1.5$ & $5.6: 0.05$ & $2.0 \div 0.5$ & $5.6 \div 1.3$ & $13.2 \div 0.1$ \\
\hline
\end{tabular}

'Average values and one standard devtation obtained from inree repllcales.

"Average values and one standard deviation obtained from all data. 
Table 0.8. Summary of properties' for nuid grout prepared from Matrix 7

\begin{tabular}{|c|c|c|c|c|c|}
\hline $\begin{array}{l}\text { Run } \\
\text { No. }\end{array}$ & $\begin{array}{c}\text { Critical } \\
\text { velocity } \\
\text { (gal/min) }\end{array}$ & $\begin{array}{l}\text { Frictional } \\
\text { pressure } \\
\text { drop } \\
(\mathrm{ps} / 100 \mathrm{n}) \\
\end{array}$ & $\begin{array}{l}\text { Pump- } \\
\text { head } \\
\text { pressure } \\
\text { (psi) }\end{array}$ & $\begin{array}{l}\text { 10-min gel } \\
\text { strength } \\
\left(1 \mathrm{~b} / 100 \mathrm{ft}^{2}\right)\end{array}$ & $\begin{array}{l}\text { Density } \\
\text { (lb/gal) }\end{array}$ \\
\hline $\begin{array}{l}M X 7.1 \\
M X 7.2 \\
M X 7.3 \\
M X 7.4 \\
M X 7.5 \\
M X 7.6 \\
M X 7.7 \\
M X 7.8 \\
M X 7.9\end{array}$ & $\begin{array}{l}18.2 \div 1.0 \\
18.0 \div 0.3 \\
18.2 \div 0.3 \\
15.4 \div 0.6 \\
16.4 \div 0.1 \\
18.3 \neq 0.9 \\
16.3 \neq 0.2 \\
17.8 \div 0.5 \\
15.2 \neq 0.7\end{array}$ & $\begin{array}{l}5.7 \neq 0.1 \\
5.6 \neq 0 \\
5.6 \pm 0 \\
5.5 \pm 0 \\
5.5 \neq 0 \\
5.6 \neq 0.1 \\
5.6 \pm 0 \\
5.7 \neq 0 \\
5.6 \pm 0\end{array}$ & $\begin{array}{l}2.5 \pm 0.1 \\
2.6 \pm 0.3 \\
2.0 \pm 0.2 \\
1.7 \pm 0.1 \\
2.0 \pm 0.2 \\
2.4 \pm 0 \\
1.7 \pm 0.1 \\
2.5 \pm 0.1 \\
2.0 \div 0.2\end{array}$ & $\begin{array}{l}6.8 \pm 0.3 \\
7.2 \pm 0.8 \\
5.5 \pm 0.5 \\
4.7 \pm 0.3 \\
5.5 \pm 0.5 \\
6.5 \pm 0 \\
4.8 \pm 0.3 \\
6.8 \pm 0.3 \\
5.5 \pm 0.5\end{array}$ & $\begin{array}{l}13.5 \pm 0 \\
13.5 \pm 0 \\
13.4 \pm 0.1 \\
13.2 \pm 0.1 \\
13.2 \pm 0 \\
13.5 \pm 0 \\
13.3 \pm 0.1 \\
13.3 \pm 0 \\
13.3 \pm 0\end{array}$ \\
\hline Averageb & $17.1=1.3$ & $5.6 \neq 0.1$ & $2.2 \div 0.4$ & $5.9 \pm 1.0$ & $13.4 \pm 0.1$ \\
\hline
\end{tabular}

-Average values and one standard deviation obtained from three replicates.

'Average values and one standard deviation obtained from all data. 
Table 6.9. Summary of properties' for fluid grout prepared from Matrix 8

\begin{tabular}{|c|c|c|c|c|c|}
\hline $\begin{array}{l}\text { Run } \\
\text { No. }\end{array}$ & $\begin{array}{c}\text { Critical } \\
\text { velocity } \\
\left(g^{a l} / \mathrm{m} / \mathrm{n}\right)\end{array}$ & $\begin{array}{l}\text { Frictional } \\
\text { pressure } \\
\text { drop } \\
(\mathrm{ps} 1 / 100 \mathrm{ft})\end{array}$ & $\begin{array}{l}\text { Pump- } \\
\text { head } \\
\text { pressure } \\
\text { (psi) }\end{array}$ & $\begin{array}{l}10-\min g \mathrm{gl} \\
\text { strength } \\
\left(1 \mathrm{~b}_{\mathrm{f}} / 100 \mathrm{ft}^{2}\right)\end{array}$ & $\begin{array}{l}\text { Density } \\
\text { (lb/gal) }\end{array}$ \\
\hline $\begin{array}{l}M X 8.1 \\
M X 8-2 \\
M X 8.3 \\
M X 8.4 \\
M X 8-5 \\
M X 8-6 \\
M X 8.7 \\
M X 8.8 \\
M X 8.9\end{array}$ & $\begin{array}{l}16.7 \pm 0.4 \\
16.0 \pm 1.2 \\
173 \pm 0.4 \\
16.6 \pm 0.5 \\
15.7 \pm 0.5 \\
14.8 \pm 0.2 \\
16.1 \pm 0.3 \\
17.1 \pm 0.8 \\
17.5 \pm 0.4\end{array}$ & $\begin{array}{l}5.6 \pm 0 \\
5.5 \pm 0 \\
5.6 \pm 0 \\
5.6 \pm 0 \\
5.5 \pm 0 \\
5.5 \pm 0 \\
5.5 \pm 0 \\
5.6 \pm 0 \\
5.7 \pm 0\end{array}$ & $\begin{array}{l}2.3 \pm 0.1 \\
1.7 \pm 0.1 \\
1.8 \pm 0 \\
1.6 \pm 0.1 \\
1.7 \pm 0.1 \\
1.4 \pm 0.2 \\
1.8 \pm 0 \\
1.9 \pm 1.1 \\
4.6 \pm 3.9\end{array}$ & $\begin{array}{l}6.3 \pm 0.3 \\
4.8 \pm 0.3 \\
5.0 \pm 0 \\
4.3 \pm 0.3 \\
4.7 \pm 0.3 \\
3.7 \pm 0.6 \\
5.0 \pm 0 \\
6.8 \pm 0.3 \\
12.7 \pm 10.7\end{array}$ & $\begin{array}{l}13.4 \pm 0 \\
13.1 \pm 0.1 \\
13.4 \pm 0 \\
13.3 \pm 0 \\
13.2 \pm 0 \\
13.1 \pm 0 \\
13.2 \pm 0 \\
13.5 \pm 0.1 \\
13.5 \pm 0\end{array}$ \\
\hline Average $^{b}$ & $16.4 \pm 0.9$ & $5.6 \neq 0.1$ & $2.2 \pm 1.4$ & $5.9 \pm 3.9$ & $13.3 \neq 0.1$ \\
\hline
\end{tabular}

Average values and one standard deviation obtained from three replicates.

Average values and one standard deviation obtained from all data. 
Table G-10. Summary of properties ${ }^{2}$ for fluid grout prepared from Matrix 9

\begin{tabular}{lccccl}
\hline Run & $\begin{array}{c}\text { Critical } \\
\text { velocity } \\
\text { (gal/min) }\end{array}$ & $\begin{array}{c}\text { Frictional } \\
\text { pressure } \\
\text { drop } \\
(\mathrm{psi} / 100 \mathrm{ft})\end{array}$ & $\begin{array}{c}\text { Pump- } \\
\text { head } \\
\text { pressure } \\
(\mathrm{psi})\end{array}$ & $\begin{array}{c}\text { 10-min gel } \\
\text { strength } \\
\left(\mathrm{lb} / 100 \mathrm{ft}^{2}\right)\end{array}$ & $\begin{array}{c}\text { Density } \\
(\mathrm{lb} / \mathrm{gal})\end{array}$ \\
\hline MX9-1 & $16.8 \pm 0.4$ & $5.6 \pm 0$ & $1.5 \pm 0.3$ & $4.2 \pm 0.8$ & $13.4 \pm 0$ \\
MX9-2 & $14.9 \pm 0.1$ & $5.5 \pm 0$ & $1.6 \pm 0.1$ & $4.3 \pm 0.3$ & $13.1 \pm 0$ \\
MX9-3 & $14.3 \pm 0.5$ & $5.5 \pm 0$ & $1.2 \pm 0.1$ & $3.2 \pm 0.3$ & $13.1 \pm 0$ \\
MX9-4 & $16.1 \pm 0.5$ & $5.6 \pm 0$ & $1.9 \pm 0.1$ & $5.2 \pm 0.3$ & $13.5 \pm 0$ \\
MX9-5 & $14.8 \pm 0.5$ & $5.6 \pm 0$ & $1.5 \pm 0.1$ & $4.2 \pm 0.3$ & $13.3 \pm 0$ \\
MX9-6 & $15.2 \pm 0.6$ & $5.5 \pm 0$ & $1.6 \pm 0.1$ & $4.3 \pm 0.3$ & $13.1 \pm 0.1$ \\
MX9-7 & $16.3 \pm 1.0$ & $5.6 \pm 0$ & $2.1 \pm 0.1$ & $5.7 \pm 0.3$ & $13.5 \pm 0.1$ \\
MX9-8 & $15.4 \pm 0.2$ & $5.5 \pm 0.1$ & $1.6 \pm 0.2$ & $4.3 \pm 0.6$ & $13.2 \pm 0$ \\
MX9-9 & $17.7 \pm 0.3$ & $5.6 \pm 0$ & $2.1 \pm 0.3$ & $5.8 \pm 0.8$ & $13.4 \pm 0$ \\
& & & & & \\
Average & $15.7 \pm 1.1$ & $5.6 \pm 0.1$ & $1.7 \pm 0.3$ & $4.6 \pm 0.9$ & $13.3 \pm 0.2$ \\
\hline
\end{tabular}

Average values and one standard deviation obtained from three replicates.

${ }^{b}$ Average values and one standard deviation obtained from all data. 
Table G-11. Summary of properties ${ }^{a}$ for fluid grout prepared from Matrix 10

\begin{tabular}{llllll}
\hline $\begin{array}{l}\text { Run } \\
\text { No. }\end{array}$ & $\begin{array}{c}\text { Critical } \\
\text { velocity } \\
(\mathrm{gal} / \mathrm{min})\end{array}$ & $\begin{array}{c}\text { Frictional } \\
\text { pressure } \\
\text { drop } \\
(\mathrm{psi} / 100 \mathrm{ft})\end{array}$ & $\begin{array}{c}\text { Pump- } \\
\text { head } \\
\text { pressure } \\
(\mathrm{psi})\end{array}$ & $\begin{array}{c}10 \text {-min gel } \\
\text { strength } \\
\left(\mathrm{lb} / 100 \mathrm{ft}^{2}\right)\end{array}$ & $\begin{array}{c}\text { Density } \\
(\mathrm{lb} / \mathrm{gal})\end{array}$ \\
\hline MX10-1 & $15.2 \pm 0.8$ & $5.5 \pm 0$ & $1.3 \pm 0.2$ & $3.5 \pm 0.5$ & $13.2 \pm 0.1$ \\
MX10-2 & $17.0 \pm 0.3$ & $5.6 \pm 0$ & $1.7 \pm 0.1$ & $4.7 \pm 0.3$ & $13.3 \pm 0$ \\
MX10-3 & $16.3 \pm 0.5$ & $5.6 \pm 0$ & $1.6 \pm 0.1$ & $4.3 \pm 0.3$ & $13.3 \pm 0$ \\
MX10-4 & $16.5 \pm 0.3$ & $5.6 \pm 0$ & $1.5 \pm 0.2$ & $4.0 \pm 0.5$ & $13.3 \pm 0$ \\
MX10-5 & $14.7 \pm 0.4$ & $5.5 \pm 0$ & $1.4 \pm 0.1$ & $3.7 \pm 0.3$ & $13.1 \pm 0$ \\
MX10-6 & $14.1 \pm 0.5$ & $5.5 \pm 0$ & $1.3 \pm 0$ & $3.5 \pm 0$ & $13.0 \pm 0.1$ \\
MX10-7 & $14.6 \pm 0.4$ & $5.5 \pm 0$ & $1.4 \pm 0.1$ & $3.7 \pm 0.3$ & $13.1 \pm 0$ \\
MX10-8 & $15.5 \pm 0.5$ & $5.6 \pm 0$ & $1.5 \pm 0.1$ & $4.2 \pm 0.3$ & $13.3 \pm 0$ \\
MX10-9 & $14.7 \pm 0.3$ & $5.5 \pm 0$ & $1.3 \pm 0$ & $3.5 \pm 0$ & $13.1 \pm 0$ \\
Average & $15.4 \pm 1.0$ & $5.5 \pm 0.1$ & $1.4 \pm 0.2$ & $3.9 \pm 0.5$ & $13.2 \pm 0.1$ \\
\hline & & & & & \\
\hline
\end{tabular}

${ }^{2}$ Average values and one standard deviation obtained from three replicates.

${ }^{b}$ Average values and one standard deviation obtained from all data. 
Table G-12. Summary of properties for fluid grout prepared from Matrix 11

\begin{tabular}{|c|c|c|c|c|c|}
\hline $\begin{array}{l}\text { Run } \\
\text { No. }\end{array}$ & $\begin{array}{c}\text { Critical } \\
\text { velocity } \\
\text { (gal/min) }\end{array}$ & $\begin{array}{l}\text { Frictional } \\
\text { pressure } \\
\text { drop } \\
(\mathrm{psi} / 100 \mathrm{ft})\end{array}$ & $\begin{array}{l}\text { Pump- } \\
\text { head } \\
\text { pressure } \\
\text { (psi) }\end{array}$ & $\begin{array}{l}\text { 10-min gel } \\
\text { strength } \\
\left(1 \mathrm{~b}_{\mathrm{f}} / 100 \mathrm{ft}^{2}\right)\end{array}$ & $\begin{array}{l}\text { Density } \\
\text { (lb/gal) }\end{array}$ \\
\hline MX11-1 & $15.1 \pm 0.4$ & $c .5 \pm 0$ & $1.5 \pm 0.1$ & $4.2 \pm 0.3$ & $13.2 \pm 0$ \\
\hline$M \times 11-2$ & $15.5 \pm 0.4$ & $5.6 \pm 0$ & $2.0 \pm 0.2$ & $5.5 \pm 0.5$ & $13.4 \pm 0$ \\
\hline MX11-3 & $15.3 \pm 0.4$ & $5.6 \pm 0$ & $1.7 \pm 0.2$ & $4.8 \pm 0.6$ & $13.4 \pm 0$ \\
\hline MX11-4 & $16.1 \pm 0.6$ & $5.6 \pm 0$ & $1.7 \pm 0.2$ & $4.7 \pm 0.6$ & $13.4 \pm 0.1$ \\
\hline$M X 11-5$ & $14.3 \pm 0.9$ & $5.5 \pm 0$ & $1.3 \pm 0$ & $3.5 \pm 0$ & $13.0 \pm 0$ \\
\hline$M \times 11-6$ & $14.1 \pm 0.4$ & $5.5 \pm 0$ & $1.3 \pm 0.2$ & $3.5 \pm 0.5$ & $13.0 \pm 0$ \\
\hline MX11-7 & $15.7 \pm 0.1$ & $5.6 \pm 0$ & $1.6 \pm 0.2$ & $4.5 \neq 0.5$ & $13.3 \pm 0$ \\
\hline MX11-8 & $14.4 \pm 0.6$ & $5.5 \pm 0$ & $1.4 \pm 0.1$ & $3.8 \pm 0.3$ & $13.1 \pm 0$ \\
\hline MX11-9 & $14.8 \pm 0.2$ & $5.5 \pm 0$ & $1.4 \pm 0.1$ & $3.8 \pm 0.3$ & $13.1 \pm 0$ \\
\hline Average $^{b}$ & $15.0 \pm 0.8$ & $5.5 \pm 0.1$ & $1.6 \pm 0.3$ & $4.1 \pm 1.0$ & $13.2 \pm 0.2$ \\
\hline
\end{tabular}

'Average values and one standard deviation obtained from three replicates.

${ }^{b}$ Average values and one standard deviation obtained from all data. 
Table G-13. Summary of properties ${ }^{2}$ for fluid grout prepared from Matrix 12

\begin{tabular}{lccccl}
\hline $\begin{array}{c}\text { Run } \\
\text { No. }\end{array}$ & $\begin{array}{c}\text { Critical } \\
\text { velocity } \\
(\mathrm{gal} / \mathrm{min})\end{array}$ & $\begin{array}{c}\text { Frictional } \\
\text { pressure } \\
\text { drop } \\
(\mathrm{ps} / 100 \mathrm{ft})\end{array}$ & $\begin{array}{c}\text { Pump- } \\
\text { head } \\
\text { pressure } \\
(\mathrm{ps})\end{array}$ & $\begin{array}{c}\text { 10-min gel } \\
\text { strength } \\
\left(\mathrm{lb} / 100 \mathrm{ft}^{2}\right)\end{array}$ & $\begin{array}{c}\text { Density } \\
(\mathrm{lb} / \mathrm{gal})\end{array}$ \\
\hline MX12-1 & $15.9 \pm 0.6$ & $5.6 \pm 0$ & $2.9 \pm 0.2$ & $8.0 \pm 0.5$ & $13.3 \pm 0$ \\
MX12-2 & $14.4 \pm 0.5$ & $5.5 \pm 0$ & $1.9 \pm 0.2$ & $5.2 \pm 0.6$ & $13.0 \pm 0$ \\
MX12-3 & $14.0 \pm 0.7$ & $5.4 \pm 0$ & $1.7 \pm 0.1$ & $4.8 \pm 0.3$ & $12.9 \pm 0.1$ \\
MX12-4 & $15.7 \pm 0.2$ & $5.5 \pm 0$ & $2.1 \pm 0.1$ & $5.8 \pm 0.3$ & $13.1 \pm 0$ \\
MX12-5 & $16.2 \pm 0.2$ & $5.5 \pm 0$ & $2.9 \pm 0.3$ & $7.8 \pm 0.8$ & $13.2 \pm 0$ \\
MX12-6 & $17.5 \pm 0.4$ & $5.6 \pm 0$ & $3.4 \pm 0.3$ & $9.5 \pm 0.9$ & $13.3 \pm 0$ \\
MX12-7 & $16.6 \pm 0.2$ & $5.6 \pm 0$ & $3.3 \pm 0.2$ & $9.0 \pm 0.5$ & $13.3 \pm 0$ \\
MX12-8 & $15.3 \pm 0.2$ & $5.5 \pm 0$ & $2.3 \pm 0.1$ & $6.3 \pm 0.3$ & $13.1 \pm 0$ \\
MX12-9 & $15.8 \pm 0.3$ & $5.5 \pm 0$ & $2.4 \pm 0.2$ & $6.5 \pm 0.5$ & $13.0 \pm 0.1$ \\
& & & & & \\
Average & $15.7 \pm 1.1$ & $5.5 \pm 0.1$ & $2.6 \pm 0.6$ & $7.0 \pm 1.7$ & $13.1 \pm 0.1$ \\
\hline
\end{tabular}

"Average values and one standard deviation obtained from three replicates.

${ }^{b}$ Average values and one standard deviation obtained from all data. 
Table 0.14. Summary of properties for fluid grout prepared from Matrix 13

\begin{tabular}{lccccl}
\hline $\begin{array}{c}\text { Run } \\
\text { No. }\end{array}$ & $\begin{array}{c}\text { Critical } \\
\text { velocity } \\
(\mathrm{gal} / \mathrm{min})\end{array}$ & $\begin{array}{c}\text { Frictional } \\
\text { pressure } \\
\text { drop } \\
(\mathrm{psi} / 100 \mathrm{ft})\end{array}$ & $\begin{array}{c}\text { Pump- } \\
\text { head } \\
\text { pressure } \\
(\mathrm{ps})\end{array}$ & $\begin{array}{c}10-\mathrm{min} \text { gel } \\
\text { strength } \\
\left(\mathrm{lb} / 100 \mathrm{f}^{2}\right)\end{array}$ & $\begin{array}{c}\text { Density } \\
(\mathrm{lb} / \mathrm{gal})\end{array}$ \\
\hline MX13-1 & $15.2 \pm 0.3$ & $5.6 \pm 0$ & $2.1 \pm 0.2$ & $5.8 \pm 0.6$ & $13.3 \pm 0$ \\
MX13-2 & $13.9 \pm 0.6$ & $5.5 \pm 0$ & $1.5 \pm 0.1$ & $4.2 \pm 0.3$ & $13.0 \pm 0$ \\
MX13-3 & $16.7 \pm 0.2$ & $5.6 \pm 0$ & $2.3 \pm 0.3$ & $6.2 \pm 0.8$ & $13.3 \pm 0.1$ \\
MX13-4 & $16.3 \pm 0.6$ & $5.6 \pm 0$ & $2.5 \pm 0.1$ & $6.7 \pm 0.3$ & $13.3 \pm 0$ \\
MX13-5 & $14.1 \pm 0.5$ & $5.5 \pm 0$ & $1.6 \pm 0$ & $4.5 \pm 0$ & $13.1 \pm 0.1$ \\
MX13-6 & $15.2 \pm 0.2$ & $5.6 \pm 0$ & $1.7 \pm 0.1$ & $4.7 \pm 0.3$ & $13.4 \pm 0$ \\
MX13-7 & $13.9 \pm 0.8$ & $5.5 \pm 0$ & $1.4 \pm 0.1$ & $3.8 \pm 0.3$ & $13.1 \pm 0.1$ \\
MX13-8 & $14.4 \pm 0.2$ & $5.5 \pm 0$ & $1.5 \pm 0.1$ & $4.2 \pm 0.3$ & $13.1 \pm 0$ \\
MX13-9 & $14.8 \pm 0.2$ & $5.5 \pm 0.1$ & $1.7 \pm 0.1$ & $4.7 \pm 0.3$ & $13.2 \pm 0$ \\
& & & & & \\
Average ${ }^{b}$ & $14.9 \pm 1.0$ & $5.5 \pm 0.1$ & $1.8 \pm 0.4$ & $5.0 \pm 1.0$ & $13.2 \pm 0.1$ \\
\hline
\end{tabular}

'Average values and one standard deviation obtained from three replicates.

${ }^{b}$ Average values and one standard deviation obtained from all data. 
Appendix H. AVERAGED DRAINABLE-WATER DATA 
Table H-1. Summary of drainable-water data for grouts prepared from Matrix 1

\begin{tabular}{lcccccc}
\hline & \multicolumn{7}{c}{ Drainable water (vol \%) observed at } \\
\cline { 2 - 7 } Run No. & $2 \mathrm{n}$ & $1 \mathrm{~d}$ & $7 \mathrm{~d}$ & $14 \mathrm{~d}$ & $21 \mathrm{~d}$ & $28 \mathrm{~d}$ \\
\hline MX1-1 & $5.3 \pm 1.3$ & $6.1 \pm 1.7$ & $4.86 \pm 1.4$ & $4.5 \pm 1.7$ & $4.5 \pm 1.7$ & $4.4 \pm 1.4$ \\
MX1-2 & $3.7 \pm 1.0$ & $4.3 \pm 1.2$ & $2.8 \pm 1.4$ & $3.1 \pm 0.8$ & $2.7 \pm 1.2$ & $2.5 \pm 1.4$ \\
MX1-3 & $5.5 \pm 0.2$ & $5.6 \pm 0.4$ & $5.1 \pm 0.6$ & $4.0 \pm 0$ & $4.0 \pm 0$ & $3.3 \pm 0.6$ \\
MX1-4 & $4.4 \pm 0.4$ & $4.1 \pm 0.6$ & $3.5 \pm 1.2$ & $2.7 \pm 0.5$ & $2.4 \pm 0.4$ & $2.4 \pm 0.7$ \\
MX1-5 & $7.1 \pm 0.2$ & $7.1 \pm 0.2$ & $6.5 \pm 0.6$ & $5.9 \pm 0.5$ & $5.6 \pm 0$ & $5.7 \pm 0.2$ \\
MX1-6 & $4.3 \pm 0.5$ & $4.1 \pm 0.6$ & $4.0 \pm 0.7$ & $3.2 \pm 0.8$ & $2.5 \pm 0.6$ & $2.4 \pm 0.7$ \\
MX1-7 & $6.9 \pm 1.6$ & $7.1 \pm 1.4$ & $6.0 \pm 1.1$ & $5.3 \pm 1.4$ & $5.3 \pm 1.2$ & $5.5 \pm 1.4$ \\
MX1-8 & $4.4 \pm 0.4$ & $4.1 \pm 0.5$ & $3.9 \pm 0.5$ & $3.3 \pm 0.2$ & $2.9 \pm 0.5$ & $2.8 \pm 0.8$ \\
MX1-9 & $9.5 \pm 1.2$ & $21.7 \pm 0.6$ & $21.1 \pm 0.5$ & $20.9 \pm 0.6$ & $21.1 \pm 0.5$ & $21.1 \pm 0.5$ \\
& & & & & & \\
Average & $5.2 \pm 1.4$ & $5.3 \pm 1.5$ & $4.6 \pm 1.5$ & $4.0 \pm 1.3$ & $3.8 \pm 1.5$ & $3.6 \pm 1.6$ \\
\hline
\end{tabular}

Average values and one standard deviation obtained from three replicates.

${ }^{b}$ Average values and one standard deviation obtained from all data except run MX1.9. 
Table $H \cdot 2$. Summary of drainable-water data for grouts prepared from Matrix 2

\begin{tabular}{llccccc}
\hline & \multicolumn{7}{c}{ Drainable water (vol \%) observed at } \\
\cline { 2 - 7 } Run No. & $2 \mathrm{~h}$ & $1 \mathrm{~d}$ & $7 \mathrm{~d}$ & $14 \mathrm{~d}$ & $21 \mathrm{~d}$ & $28 \mathrm{~d}$ \\
\hline MX2-1 & $\mathbf{8 . 4 \pm 1 . 5}$ & $9.5 \pm 2.7$ & $\mathbf{8 . 3} \pm 2.9$ & $8.1 \pm 3.1$ & $7.7 \pm 2.4$ & $7.9 \pm 2.7$ \\
MX2-2 & $13.3 \pm 1.8$ & $19.6 \pm 0.8$ & $18.5 \pm 1.0$ & $18.5 \pm 0.5$ & $18.3 \pm 0.6$ & $18.1 \pm 0.5$ \\
MX2-3 & $14.0 \pm 0.4$ & $20.4 \pm 0.7$ & $19.2 \pm 0.8$ & $18.9 \pm 0.5$ & $18.5 \pm 0.6$ & $18.1 \pm 0.5$ \\
MX2-4 & $11.5 \pm 1.7$ & $14.3 \pm 2.7$ & $13.5 \pm 2.3$ & $12.7 \pm 2.3$ & $12.8 \pm 2.4$ & $12.8 \pm 2.4$ \\
MX2-5 & $11.1 \pm 0.8$ & $16.9 \pm 0.8$ & $14.9 \pm 0.9$ & $15.5 \pm 1.0$ & $15.5 \pm 0.9$ & $15.3 \pm 1.2$ \\
MX2-6 & $12.7 \pm 1.2$ & $13.3 \pm 2.0$ & $11.9 \pm 1.9$ & $11.6 \pm 1.8$ & $11.3 \pm 1.6$ & $11.6 \pm 1.7$ \\
MX2-7 & $8.8 \pm 0.4$ & $9.1 \pm 1.7$ & $7.7 \pm 1.2$ & $7.5 \pm 0.9$ & $7.2 \pm 1.1$ & $7.3 \pm 0.8$ \\
MX2-8 & $11.3 \pm 0.2$ & $16.8 \pm 0.4$ & $15.3 \pm 1.3$ & $15.2 \pm 1.4$ & $15.2 \pm 1.4$ & $15.1 \pm 1.5$ \\
MX2.9 & $9.5 \pm 1.0$ & $14.4 \pm 3.2$ & $12.8 \pm 3.7$ & $12.0 \pm 3.2$ & $12.3 \pm 3.6$ & $12.1 \pm 3.4$ \\
& & & & & & \\
Averageb & $11.2 \pm 2.1$ & $14.9 \pm 4.1$ & $13.6 \pm 4.2$ & $13.4 \pm 9.2$ & $13.2 \pm 4.2$ & $13.2 \pm 4.1$ \\
\hline
\end{tabular}

"Average values and one standard deviation obtained from three replicates.

Average value and one standard deviation obtained from all data. 
Table H-3. Summary of drainable-water data for grouts prepared from Matrix $2 R$

\begin{tabular}{|c|c|c|c|c|c|c|}
\hline \multirow[b]{2}{*}{ Run No. } & \multicolumn{6}{|c|}{ Drainable water (vol \%) observed at } \\
\hline & $2 \mathrm{~h}$ & $1 d$ & $7 d$ & $14 \mathrm{~d}$ & $21 \mathrm{~d}$ & $28 \mathrm{~d}$ \\
\hline $\begin{array}{l}\text { MX2R-1 } \\
\text { MX2R-2 } \\
\text { MX2R-3 } \\
\text { MX2R-4 } \\
\text { MX2R.5 } \\
\text { MX2R-6 } \\
\text { MX2R-7 } \\
\text { MX2R-8 } \\
\text { MX2R-9 }\end{array}$ & $\begin{array}{l}3.9 \pm 0.2 \\
11.2 \pm 0.8 \\
12.3 \pm 0.5 \\
7.1 \pm 0.2 \\
9.2 \pm 0.7 \\
12.4 \pm 0.4 \\
8.1 \pm 0.6 \\
9.5 \pm 0.2 \\
7.5 \pm 0.2\end{array}$ & $\begin{array}{l}3.6^{b} \\
12.5=1.2 \\
14.0 \neq 0.7 \\
8.0 \neq 1.1 \\
9.9 \neq 0.9 \\
12.8 \neq 0 \\
7.9 \neq 0.8 \\
10.8 \pm 0.7 \\
6.9 \neq 0.5\end{array}$ & $\begin{array}{l}3.6^{b} \\
12.4 \neq 1.2 \\
13.9 \pm 0.9 \\
6.9 \neq 0.5 \\
9.2 \neq 0.4 \\
12.1 \pm 0.5 \\
7.5 \neq 0.5 \\
9.5 \pm 1.5 \\
6.1 \pm 0.5\end{array}$ & $\begin{array}{l}3.2^{b} \\
12.0=1.2 \\
13.9=0.9 \\
6.9=0.5 \\
8.9=0.2 \\
11.9=0.2 \\
6.5=0.6 \\
8.9=1.3 \\
5.6=0.8\end{array}$ & $\begin{array}{l}2.6^{b} \\
12.0 \pm 1.2 \\
13.9 \pm 0.9 \\
6.8 \pm 0.7 \\
8.8 \pm 0.4 \\
11.9 \pm 0.2 \\
6.5 \pm 0.6 \\
8.9 \pm 1.3 \\
5.5 \pm 0.6\end{array}$ & $\begin{array}{l}2.0^{5} \\
11.7 \pm 1.2 \\
14.0 \pm 1.1 \\
6.8 \pm 0.7 \\
8.4 \pm 0 \\
11.5 \pm 0.6 \\
6.4 \pm 0.8 \\
8.8 \pm 1.4 \\
5.3 \pm 0.6\end{array}$ \\
\hline Averaged $^{d}$ & $9.0 \div 2.3$ & $9.8 \neq 3.1$ & $9.2 \neq 3.2$ & $8.9 \pm 3.3$ & $8.8 \div 3.4$ & $9.1 \pm 3.0$ \\
\hline
\end{tabular}


Table H-4. Summary of drainable-water data for grouts prepared from Matrix 3

\begin{tabular}{|c|c|c|c|c|c|c|}
\hline \multirow[b]{2}{*}{ Run No. } & \multicolumn{6}{|c|}{ Drainable water (vol \%) observed at } \\
\hline & $2 h$ & $1 d$ & $7 d$ & $14 d$ & $21 d$ & $28 \mathrm{~d}$ \\
\hline $\begin{array}{l}M \times 3.1 \\
M X 3.2 \\
M X 3.3 \\
M X 3.4 \\
M \times 3.5 \\
M \times 3.6 \\
M X 3.7 \\
M \times 3.8 \\
M \times 3.9\end{array}$ & $\begin{array}{l}7.2 \div 2.2 \\
9.7 \div 2.6 \\
6.5 \div 3.0 \\
12.0 \div 0.4 \\
8.9 \div 1.6 \\
6.3 \div 2.2 \\
8.9 \div 3.0 \\
9.7 \div 0.8 \\
8.1 \div 1.5\end{array}$ & $\begin{array}{l}9.7 \neq 2.8 \\
11.2 \div 2.9 \\
6.5 \div 2.3 \\
13.9 \neq 1.0 \\
9.5 \div 2.0 \\
9.1 \div 1.0 \\
18.1 \neq 1.5 \\
12.8 \neq 1.4 \\
9.2 \div 1.7\end{array}$ & $\begin{array}{l}7.6 \div 2.9 \\
10.0 \div 3.3 \\
5.5 \div 2.7 \\
12.8 \div 0.7 \\
8.8 \div 2.0 \\
8.3 \neq 1.0 \\
15.9 \neq 1.9 \\
11.9 \neq 1.0 \\
8.1 \div 1.9\end{array}$ & $\begin{array}{l}7.6 \div 3.0 \\
9.5 \div 3.5 \\
5.5 \div 2.3 \\
12.7 \div 1.3 \\
8.4 \div 2.0 \\
8.3 \div 1.2 \\
16.0 \div 1.8 \\
11.6 \div 1.2 \\
7.7 \div 1.9\end{array}$ & $\begin{array}{l}7.5 \div 2.7 \\
9.3 \div 3.2 \\
5.2 \div 2.5 \\
12.5 \div 1.2 \\
8.3 \div 2.0 \\
8.1 \div 1.3 \\
15.9 \div 1.9 \\
11.9 \div 1.4 \\
7.7 \div 1.9\end{array}$ & $\begin{array}{l}7.3 \div 2.7 \\
8.8 \div 3.3 \\
5.1 \div 2.6 \\
12.5 \div 0.8 \\
8.3 \div 2.0 \\
8.3 \div 1.2 \\
15.9 \div 1.9 \\
11.6 \div 1.2 \\
7.7: 1.9\end{array}$ \\
\hline Average $^{b}$ & $8.6 \div 2.5$ & $11.1 \pm 3.7$ & $9.9=3.5$ & $9.7 \geq 3.6$ & $9.6 * 3.6$ & $9.5 \div 3.6$ \\
\hline
\end{tabular}

-Average values and one standard deviation obtained from three replicates.

'Average values and one standard deviation obtained trom all data. 
Table H-3. Summary of drainable-water data for grouts prepared frum Matrix 4

\begin{tabular}{|c|c|c|c|c|c|c|}
\hline \multirow[b]{2}{*}{ Run No. } & \multicolumn{6}{|c|}{ Drainable water (vol \%) observed at } \\
\hline & $2 \mathrm{~h}$ & Id & $7 d$ & $14 d$ & $21 d$ & $28 d$ \\
\hline $\begin{array}{l}M X 4.1 \\
M X 4.2 \\
M X 4.3 \\
M X 4.4 \\
M X 4.5 \\
M X 4.6 \\
M X 4.7 \\
M X 4.8 \\
M X 4.9\end{array}$ & $\begin{array}{l}8.4: 2.4 \\
4.7 \div 0.8 \\
5.6: 0.7 \\
4.8: 0.8 \\
6.9: 1.2 \\
10.4: 0.4 \\
8.0 \div 0.7 \\
4.5 \div 1.2 \\
7.8 \div 0.2\end{array}$ & $\begin{array}{l}8.9: 2.9 \\
4.9: 1.0 \\
5.3: 1.2 \\
4.5: 0.9 \\
7.9: 1.3 \\
12.3: 0.5 \\
8.9: 0.5 \\
4.7: 0.8 \\
9.1: 0.8\end{array}$ & $\begin{array}{l}7.9: 3.0 \\
3.6=1.1 \\
4.1: 1.6 \\
3.1: 0.8 \\
7.1: 1.6 \\
11.7 \div 0.9 \\
7.3: 0.5 \\
3.2 \div 1.6 \\
7.7: 0.9\end{array}$ & $\begin{array}{l}7.9: 3.0 \\
3.3: 1.0 \\
4.0 \div 1.8 \\
2.9: 0.9 \\
6.4: 1.4 \\
11.5: 0.5 \\
6.9: 0.5 \\
3.2: 1.6 \\
7.6: 1.1\end{array}$ & $\begin{array}{l}7.9: 3.0 \\
2.9: 1.0 \\
3.2: 2.1^{6} \\
2.8: 1.1 \\
6.4: 1.4 \\
11.3: 0.6 \\
6.9: 0.5 \\
3.2: 1.6 \\
7.5: 0.8\end{array}$ & $\begin{array}{l}7.9 \div 3.0 \\
2.8 \div 1.1 \\
2.9 \div 2.6^{b} \\
2.1 \div 0.9 \\
6.4: 1.4 \\
11.1: 0.8 \\
6.9: 0.5 \\
3.2 \div 1.6 \\
7.2: 0.7\end{array}$ \\
\hline Average" & $6.8 * 2.1$ & $7.4 \cdot 2.3$ & $6.2 * 3.1$ & $6.0 \div 3.0$ & $6.0 \div 3.0^{d}$ & $5.8 \div 3.1^{\mathrm{d}}$ \\
\hline
\end{tabular}


Table H.6. Summary of drainable-water data for grouts prepared from Marrix 5

\begin{tabular}{|c|c|c|c|c|c|c|}
\hline \multirow[b]{2}{*}{ Run No. } & \multicolumn{6}{|c|}{ Drainable water (vol \%)" observed at } \\
\hline & $2 n$ & $1 d$ & $7 d$ & $14 d$ & $21 d$ & $28 \mathrm{~d}$ \\
\hline $\begin{array}{l}\text { MX5.1 } \\
\text { MXs.2 } \\
\text { MX5.3 } \\
\text { MXs.4 } \\
\text { MX5.5 } \\
\text { MX5.6 } \\
\text { MX5.7 } \\
\text { MX5.8 } \\
\text { MX5.9 }\end{array}$ & $\begin{array}{l}4.5=0.9 \\
8.9=0.6 \\
8.0=0 \\
7.1=0.6 \\
5.7=0.2 \\
4.4=0.7 \\
3.1=0.5 \\
4.0=0.8 \\
5.5=1.0\end{array}$ & $\begin{array}{l}5.9=0.9 \\
10.7=0.5 \\
8.8=0.0 \\
7.3=0.0 \\
7.2=0.8 \\
4.5=0.5 \\
3.2=0 \\
5.1=1.2 \\
7.3=1.4\end{array}$ & $\begin{array}{l}3.9=08 \\
9.3: 0.6 \\
7.6 \div 0.7 \\
6.3: 0.8 \\
5.5 \div 0.8 \\
3.1: 1.0 \\
2.3: 0.2 \\
4.0 \div 0.8 \\
5.9 \div 1.7\end{array}$ & $\begin{array}{l}4.5: 0.2 \\
9.3: 0.9 \\
7.3 \div 0.2 \\
6.1 \neq 0.9 \\
5.5: 0.8 \\
3.1: 1.0 \\
1.5 \div 0.2 \\
3.5 \neq 0.8 \\
5.2: 2.0\end{array}$ & $\begin{array}{l}3.7 \neq 0.9 \\
9.1 \neq 0.5 \\
7.3 \neq 0.2 \\
5.9 \neq 0.8 \\
5.5 \neq 0.8\end{array}$ & $\begin{array}{l}3.7: 0.9 \\
8.9: 0.2 \\
7.3: 0.2 \\
5.7: 0.6 \\
4.5: 1.0 \\
2.3: 0.8 \\
1.5: 0.2 \\
3.1: 0.8 \\
5.1=1.8\end{array}$ \\
\hline Average" & $5.7: 2.0$ & $6.7 \bullet 2.3$ & $5.3 \div 2.3$ & $5.1 * 2.4$ & $9.7 \div 2.1$ & $4.7 \div 2.4$ \\
\hline
\end{tabular}

'Average values and one standard deviation obtained from three replicates.

Average values and one standard deviation obtained from all data. 
Table H-7. Summary of drainable.water data for grouts prepared from Matrix 6

\begin{tabular}{|c|c|c|c|c|c|c|}
\hline \multirow[b]{2}{*}{ Run No. } & \multicolumn{6}{|c|}{ Drainable water (vol $\%)^{4}$ observed at } \\
\hline & $2 h$ & 10 & $7 d$ & $14 d$ & $21 d$ & $28 \mathrm{~d}$ \\
\hline $\begin{array}{l}\text { MX6.1 } \\
\text { MX6-2 } \\
\text { MX6-3 } \\
\text { MX6-4 } \\
\text { MX6-5 } \\
\text { MX6-6 } \\
\text { MX6.7 } \\
\text { MX6-8 } \\
\text { MX6-9 }\end{array}$ & $\begin{array}{l}3.1: 0.8 \\
5.2: 0.7 \\
2.9 \neq 0.2 \\
2.8 \div 0.4 \\
6.9 \neq 1.2 \\
4.3: 0.6 \\
5.9 \neq 0.5 \\
6.8 \neq 1.7 \\
3.2: 0.8\end{array}$ & $\begin{array}{l}3.2: 1.1 \\
5.2=0.7 \\
3.7: 0.2 \\
3.1=0.8 \\
7.7 \div 1.5 \\
4.7 \div 0.6 \\
6.4=0.8 \\
6.4 \div 2.1 \\
3.6 \div 0.6\end{array}$ & 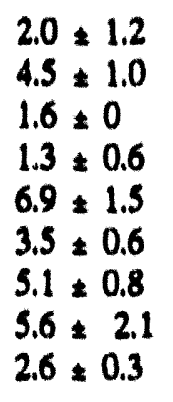 & $\begin{array}{l}1.5 \neq 0.8 \\
3.6 \neq 0.7 \\
1.9 \neq 0.2 \\
1.2 \neq 0.7 \\
6.3 \neq 1.6 \\
3.1 \neq 0.8 \\
4.7 \neq 0.8 \\
5.2 \neq 2.4 \\
2.2 \neq 0.3\end{array}$ & $\begin{array}{l}1.5 \pm 0.8 \\
3.6 \pm 0.7 \\
1.6 \pm 0 \\
1.2 \pm 0.7 \\
6.3 \pm 1.6 \\
2.9 \pm 0.6 \\
4.7 \pm 0.8 \\
5.1 \pm 2.2 \\
2.2 \pm 0.3\end{array}$ & $\begin{array}{l}1.3 \neq 0.6 \\
3.6 \pm 0.7 \\
1.6 \pm 0 \\
0.9 \pm 0.6 \\
5.5 \neq 1.5 \\
2.7 \neq 0.5 \\
4.7 \neq 0.8 \\
4.7 \neq 2.2 \\
1.8 \neq 0.9\end{array}$ \\
\hline Averageb & $4.6 \cdot 1.8$ & $4.9 * 1.8$ & $3.8 \pm 2.1$ & $3.3 \neq 2.0$ & $3.4 \div 1.9$ & $3.1 * 1.9$ \\
\hline
\end{tabular}

-Average values and one standard deviation obtained from three replicates.

'Average values and one standard deviation obtained from all data. 
Table H-8. Summary of drainable-water data for grouts prepared from Matrix 7

\begin{tabular}{lccccccc}
\hline & \multicolumn{7}{c}{ Drainable water (vol \%) observed at } \\
\cline { 2 - 8 } Run No. & $2 \mathrm{~h}$ & $1 \mathrm{~d}$ & $\mathbf{7 d}$ & $14 \mathrm{~d}$ & $21 \mathrm{~d}$ & $28 \mathrm{~d}$ \\
\hline MX7.1 & $2.8 \pm 1.1$ & $4.0 \pm 1.4$ & $3.6 \pm 1.4$ & $3.2 \pm 1.4$ & $3.1 \pm 1.3$ & $3.1 \pm 1.3$ \\
MX7.2 & $2.1 \pm 0.2$ & $1.7 \pm 12$ & $1.6 \pm 0$ & $1.6 \pm 0$ & $1.2 \pm 0$ & $0.8 \pm 0$ \\
MX7.3 & $4.4 \pm 0.7$ & $4.4 \pm 0.8$ & $4.0 \pm 0.4$ & $3.6 \pm 0.4$ & $3.5 \pm 0.6$ & $3.5 \pm 0.6$ \\
MX7.4 & $5.9 \pm 0.5$ & $8.1 \pm 0.6$ & $7.7 \pm 0.6$ & $7.1 \pm 0.6$ & $6.9 \pm 0.5$ & $6.8 \pm 0.4$ \\
MX7.5 & $4.0 \pm 0.7$ & $4.1 \pm 0.5$ & $3.5 \pm 0.9$ & $3.2 \pm 0.8$ & $3.1 \pm 0.6$ & $2.8 \pm 0.7$ \\
MX7.6 & $2.3 \pm 0.2$ & $2.3 \pm 0.2$ & $1.2 \pm 0.4$ & $1.3 \pm 0.5$ & $1.2 \pm 0.4$ & $1.1 \pm 0.5$ \\
MX7.7 & $4.8 \pm 1.1$ & $5.2 \pm 1.1$ & $4.7 \pm 1.2$ & $4.3 \pm 1.2$ & $4.3 \pm 1.2$ & $4.0 \pm 1.4$ \\
MX7.8 & $2.1 \pm 0.2$ & $2.0 \pm 0.4$ & $1.6 \pm 0$ & $1.2 \pm 0$ & $1.2 \pm 0$ & $0.9 \pm 0.2$ \\
MX7.9 & $4.0 \pm 0.8$ & $3.1 \pm 0.6$ & $3.1 \pm 0.6$ & $3.1 \pm 0.6$ & $2.7 \pm 0.8$ & $2.7 \pm 0.8$ \\
& & & & & & \\
Averageb & $3.6 \pm 1.4$ & $3.9 \pm 2.0$ & $3.4 \pm 2.0$ & $3.2 \pm 1.9$ & $3.0 \pm 1.9$ & $2.8 \pm 1.9$ \\
\hline
\end{tabular}

Average values and one standard deviation obtained from three replicates.

Average values and one standard deviation obtained from all data. 
Table H.9. Summary of drainable-water data for grouts prepared from Matrix 8

\begin{tabular}{lcccccc}
\hline & \multicolumn{6}{c}{ Drainable water (vol \%) observed at } \\
\cline { 2 - 7 } Run No. & $2 \mathrm{~b}$ & $1 \mathrm{~d}$ & $7 \mathrm{~d}$ & $14 \mathrm{~d}$ & $2.1 \mathrm{~d}$ & $28 \mathrm{~d}$ \\
\hline MX8-1 & $3.3 \pm 0.2$ & $3.3 \pm 1.0$ & $2.7 \pm 1.5$ & $2.7 \pm 1.5$ & $2.5 \pm 1.3$ & $2.3 \pm 1.2$ \\
MX8-2 & $6.5 \pm 0.2$ & $7.3 \pm 0.2$ & $6.9 \pm 0.2$ & $6.7 \pm 0.5$ & $6.4 \pm 0.4$ & $6.0 \pm 0.4$ \\
MX8-3 & $3.5 \pm 1.0$ & $3.2 \pm 1.4$ & $3.1 \pm 1.3$ & $2.8 \pm 1.1$ & $2.8 \pm 0^{\mathrm{b}}$ & $2.6 \pm 0.3^{\mathrm{b}}$ \\
MX8-4 & $6.7 \pm 0.5$ & $6.5 \pm 0.2$ & $5.7 \pm 0.5$ & $5.6 \pm 0.4$ & $5.6 \pm 0.4$ & $5.3 \pm 0.5$ \\
MX8-5 & $7.5 \pm 0.6$ & $7.7 \pm 0.8$ & $7.3 \pm 1.2$ & $7.1 \pm 1.3$ & $6.7 \pm 1.0$ & $6.7 \pm 0.9$ \\
MX8-6 & $7.5 \pm 0.5$ & $8.0 \pm 0$ & $7.1 \pm 0.2$ & $6.7 \pm 0.2$ & $6.4 \pm 0$ & $6.4 \pm 0.4$ \\
MX8-7 & $7.9 \pm 0.6$ & $8.8 \pm 1.1$ & $8.3 \pm 0.9$ & $8.1 \pm 0.8$ & $7.9 \pm 0.9$ & $7.6 \pm 0.7$ \\
MX8-8 & $5.6 \pm 0$ & $5.7 \pm 0.6$ & $5.6 \pm 0.7$ & $4.8 \pm 0.7$ & $4.8 \pm 0.7$ & $4.8 \pm 0.7$ \\
MX8-9 & $2.5 \pm 0.2$ & $2.6 \pm 0.3^{\mathrm{b}}$ & $2.2 \pm 0.3^{\mathrm{b}}$ & $2.0 \pm 0.6^{\mathrm{b}}$ & $1.8 \pm 0.3^{\mathrm{b}}$ & $1.6 \pm 0^{\mathrm{b}}$ \\
& & & & & & \\
Average $^{\mathrm{b}}$ & $5.7 \pm 2.0$ & $6.1 \pm 2.3$ & $5.5 \pm 2.2$ & $5.3 \pm 2.2$ & $5.2 \pm 2.1$ & $5.1 \pm 2.1$ \\
\hline
\end{tabular}

2Average values and one standard deviation obtained from three replicates.

${ }^{b}$ Average of only two replicates due to leaking cylinder on third.

${ }^{c}$ Average values and one standard deviation obtained from all data. 
Table H-10. Summary of drainable-water data for grouts prepared from Matrix 9

\begin{tabular}{lllllll}
\hline & \multicolumn{6}{c}{ Drainable water (vol \%) observed at } \\
\cline { 2 - 7 } Run No. & \multicolumn{1}{c}{$2 \mathrm{~b}$} & \multicolumn{1}{c}{$1 \mathrm{~d}$} & \multicolumn{1}{c}{$7 \mathrm{~d}$} & $14 \mathrm{~d}$ & \multicolumn{1}{c}{$21 \mathrm{~d}$} & \multicolumn{1}{c}{$28 \mathrm{~d}$} \\
\hline MX9-1 & $6.7 \pm 0.2$ & $7.3 \pm 0.2$ & $6.5 \pm 0.2$ & $6.4 \pm 0.4$ & $5.7 \pm 0.2$ & $6.0 \pm 0.4$ \\
MX9-2 & $8.0 \pm 0$ & $8.9 \pm 0.8$ & $8.4 \pm 1.1$ & $8.1 \pm 1.0$ & $7.9 \pm 0.8$ & $7.9 \pm 0.8$ \\
MX9-3 & $10.0 \pm 0.7$ & $10.9 \pm 2.3$ & $9.9 \pm 2.2$ & $9.9 \pm 2.2$ & $9.7 \pm 1.6$ & $9.9 \pm 1.9$ \\
MX9-4 & $6.1 \pm 1.2$ & $6.7 \pm 1.7$ & $6.9 \pm 0.5$ & $6.6^{\mathrm{b}}$ & $6.2^{\mathrm{b}}$ & $6.2^{\mathrm{b}}$ \\
MX9-5 & $7.9 \pm 0.2$ & $8.5 \pm 0.5$ & $7.5 \pm 0.2$ & $6.9 \pm 0.5$ & $6.8 \pm 0.7$ & $6.9 \pm 0.5$ \\
MX9-6 & $\mathbf{8 . 1 \pm 0 . 6}$ & $8.7 \pm 0.5$ & $7.7 \pm 0.5$ & $7.7 \pm 0.4$ & $7.5 \pm 0.5$ & $7.1 \pm 0.8$ \\
MX9-7 & $6.0 \pm 1.2$ & $6.5 \pm 2.2$ & $5.5 \pm 2.0$ & $4.0^{\mathrm{b}}$ & $4.0^{\mathrm{b}}$ & $4.0^{\mathrm{b}}$ \\
MX9-8 & $9.2 \pm 0.8$ & $10.1 \pm 0.8$ & $9.1 \pm 0.9$ & $8.9 \pm 0.8$ & $8.9 \pm 0.8$ & $8.7 \pm 0.6$ \\
MX9-9 & $6.5 \pm 0.6$ & $6.8 \pm 0.7$ & $5.7 \pm 1.0$ & $5.2 \pm 0.7$ & $5.5 \pm 0.8$ & $5.1 \pm 0.8$ \\
& & & & & & \\
Average $^{\mathrm{b}}$ & $7.6 \pm 1.5$ & $8.3 \pm 1.9$ & $7.5 \pm 1.7$ & $7.2 \pm 1.9$ & $7.1 \pm 1.8$ & $7.0 \pm 1.9$ \\
\hline
\end{tabular}

'Average values and one standard deviation obtained from three replicates.

${ }^{b}$ Average value obtained from two replicates.

cAverage values and one standard deviation obtained from all data. 
Table H-11. Summary of drainable-water data for grouts prepared from Matrix 10

\begin{tabular}{lllllll}
\hline & \multicolumn{6}{c}{ Drainable water (vol \%) $)^{\mathrm{a}}$ observed at } \\
\cline { 2 - 7 } Run No. & \multicolumn{7}{c}{$2 \mathrm{~h}$} & \multicolumn{1}{c}{$1 \mathrm{~d}$} & \multicolumn{1}{c}{$7 \mathrm{~d}$} & $14 \mathrm{~d}$ & $21 \mathrm{~d}$ & $28 \mathrm{~d}$ \\
\hline MX10-1 & $8.1 \pm 0.2$ & $9.7 \pm 0.2$ & $8.4 \pm 0.4$ & $8.3 \pm 0.5$ & $8.1 \pm 0.2$ & $7.7 \pm 0.8$ \\
MX10-2 & $7.5 \pm 0.5$ & $8.0 \pm 0.8$ & $7.1 \pm 0.8$ & $6.4 \pm 1.1$ & $6.5 \pm 1.3$ & $6.4 \pm 1.4$ \\
MX10-3 & $7.6 \pm 0$ & $7.5 \pm 0.5$ & $6.5 \pm 0.2$ & $6.4 \pm 0$ & $6.1 \pm 0.5$ & $6.3 \pm 0.2$ \\
MX10-4 & $7.2 \pm 0.4$ & $8.1 \pm 0.2$ & $6.8 \pm 0.4$ & $6.8 \pm 0.4$ & $6.5 \pm 0.6$ & $6.1 \pm 0.2$ \\
MX10-5 & $8.3 \pm 0.5$ & $9.3 \pm 0.6$ & $8.1 \pm 0.8$ & $8.0 \pm 0.7$ & $7.9 \pm 0.6$ & $7.7 \pm 0.6$ \\
MX10-6 & $11.9 \pm 0.2$ & $13.3 \pm 2.0$ & $12.1 \pm 2.3$ & $12.1 \pm 2.0$ & $12.0 \pm 2.1$ & $11.9 \pm 2.2$ \\
MX10-7 & $10.3 \pm 0.6$ & $11.2 \pm 0.8$ & $9.7 \pm 0.8$ & $9.6 \pm 0.7$ & $9.5 \pm 0.6$ & $9.3 \pm 0.5$ \\
MX10-8 & $8.8 \pm 0$ & $9.6 \pm 0.4$ & $7.9 \pm n 5$ & $7.7 \pm 0.9$ & $7.7 \pm 0.7$ & $7.7 \pm 0.7$ \\
MX10-9 & $10.4 \pm 1.1$ & $12.1 \pm 0.2$ & $11.5 \pm 0.6$ & $11.5 \pm 0.5$ & $11.1 \pm 0.6$ & $10.9 \pm 0.6$ \\
& & & & & & \\
Average $^{b}$ & $8.9 \pm 1.6$ & $9.9 \pm 2.0$ & $8.7 \pm 2.1$ & $8.5 \pm 2.2$ & $8.4 \pm 2.2$ & $8.2 \pm 2.2$ \\
\hline
\end{tabular}

"Average values and one standard deviation obtained from three replicates.

${ }^{b}$ Average values and one standard deviation obtained from all data. 
Table H-12. Summary of drainable-water data for grouts prepared from Matrix 11

\begin{tabular}{|c|c|c|c|c|c|c|}
\hline \multirow[b]{2}{*}{ Run No. } & \multicolumn{6}{|c|}{ Drainable water $(\mathrm{vol} \%)^{2}$ observed at } \\
\hline & $2 \mathrm{~h}$ & $1 \mathrm{~d}$ & $7 d$ & $14 \mathrm{~d}$ & $21 \mathrm{~d}$ & $28 \mathrm{~d}$ \\
\hline $\begin{array}{l}\text { MX11-1 } \\
\text { MX11-2 } \\
\text { MX11-3 } \\
\text { MX11-4 } \\
\text { MX11-5 } \\
\text { MX11-6 } \\
\text { MX11-7 } \\
\text { MX11.8 } \\
\text { MX11-9 }\end{array}$ & $\begin{array}{l}8.4 \pm 0.4 \\
7.2 \pm 0.8 \\
7.5 \pm 0.6 \\
7.7 \pm 0.2 \\
10.4 \pm 0.8 \\
9.1 \pm 1.2 \\
7.3 \pm 0.2 \\
8.8 \pm 0.4 \\
10.4 \pm 1.7\end{array}$ & $\begin{array}{l}9.6 \pm 0.4 \\
8.1 \pm 1.2 \\
7.7 \pm 0.8 \\
8.8 \pm 0.4 \\
11.1 \pm 1.3 \\
10.3 \pm 0.8 \\
8.0 \pm 0.4 \\
9.3 \pm 0.5 \\
11.7 \pm 1.3\end{array}$ & $\begin{array}{l}9.3 \pm 0.2 \\
7.2 \pm 1.1 \\
7.1 \pm 0.9 \\
8.0 \pm 0.4 \\
10.7 \pm 1.3 \\
9.6 \pm 0.8 \\
7.1 \pm 0.5 \\
8.7 \pm 0.6 \\
11.1 \pm 1.2\end{array}$ & $\begin{array}{l}9.1 \pm 0.5 \\
6.9 \pm 1.2 \\
6.7 \pm 0.9 \\
7.7 \pm 0.5 \\
10.3 \pm 1.0 \\
9.6 \pm 0.8 \\
6.7 \pm 0.5 \\
8.4 \pm 0.8 \\
10.9 \pm 1.0\end{array}$ & $\begin{array}{l}8.3 \pm 0.5 \\
6.7 \pm 0.9 \\
6.4 \pm 0.8 \\
7.6 \pm 0.4 \\
10.1 \pm 0.8 \\
9.5 \pm 0.8 \\
6.7 \pm 0.5 \\
8.0 \pm 0.7 \\
10.7 \pm 1.2\end{array}$ & $\begin{array}{l}8.3 \pm 0.5 \\
6.7 \pm 0.9 \\
6.3 \pm 0.6 \\
7.2 \pm 0 \\
9.7 \pm 0.8 \\
9.2 \pm 1.1 \\
6.7 \pm 0.5 \\
8.0 \pm 0.7 \\
10.5 \pm 1.0\end{array}$ \\
\hline Average $^{b}$ & $8.5 \pm 1.4$ & $9.4 \pm 1.5$ & $8.7 \pm 1.6$ & $8.5 \pm 1.7$ & $8.2 \pm 1.6$ & $8.1 \pm 1.6$ \\
\hline
\end{tabular}

"Average values and one standard deviation obtained from three replicates.

${ }^{b}$ Average values and one standard deviation obtained from all data. 
Table H-13. Summary of drainable-water for grouts prepared from Matrix 12

\begin{tabular}{lcccccc}
\hline & \multicolumn{6}{c}{ Drainable water (vol \%) observed at } \\
\cline { 2 - 7 } Run No. & $2 \mathrm{~h}$ & $1 \mathrm{~d}$ & $7 \mathrm{~d}$ & $14 \mathrm{~d}$ & $21 \mathrm{~d}$ & $28 \mathrm{~d}$ \\
\hline MX12-1 & $4.9 \pm 0.2$ & $5.3 \pm 0.5$ & $4.3 \pm 0.2$ & $4.0 \pm 0.4$ & $4.0 \pm 0.4$ & $4.0 \pm 0.4$ \\
MX12-2 & $6.5 \pm 0.2$ & $6.9 \pm 0.5$ & $5.3 \pm 0.5$ & $5.3 \pm 0.5$ & $5.3 \pm 0.5$ & $5.3 \pm 0.5$ \\
MX12-3 & $6.5 \pm 0.2$ & $7.5 \pm 1.2$ & $6.4 \pm 1.1$ & $6.4 \pm 1.1$ & $6.4 \pm 1.1$ & $6.4 \pm 1.1$ \\
MX12-4 & $5.6 \pm 0$ & $5.6 \pm 0$ & $4.0 \pm 0.4$ & $4.0 \pm 0.4$ & $4.0 \pm 0.4$ & $4.0 \pm 0.4$ \\
MX12-5 & $4.8 \pm 0.8$ & $5.2 \pm 0.4$ & $3.2 \pm 0$ & $3.5 \pm 0.5$ & $3.3 \pm 0.2$ & $3.2 \pm 0.4$ \\
MX12-6 & $4.8 \pm 0.8$ & $4.7 \pm 1.3$ & $3.6 \pm 1.2$ & $3.6 \pm 1.2$ & $3.6 \pm 1.2$ & $3.6 \pm 1.2$ \\
MX12-7 & $5.6 \pm 0.8$ & $5.9 \pm 1.3$ & $4.9 \pm 1.6$ & $4.9 \pm 1.6$ & $4.8 \pm 1.4$ & $4.8 \pm 1.4$ \\
MX12-8 & $5.2 \pm 0.7$ & $5.9 \pm 1.3$ & $4.7 \pm 1.3$ & $4.7 \pm 1.3$ & $4.5 \pm 1.2$ & $4.5 \pm 1.2$ \\
MX12-9 & $5.7 \pm 0.8$ & $5.9 \pm 0.9$ & $4.8 \pm 0.8$ & $4.8 \pm 0.8$ & $4.5 \pm 0.8$ & $4.5 \pm 0.8$ \\
& & & & & & \\
Average & $5.5 \pm 0.8$ & $5.9 \pm 1.1$ & $4.6 \pm 1.2$ & $4.6 \pm 1.2$ & $4.5 \pm 1.2$ & $4.5 \pm 1.2$ \\
\hline
\end{tabular}

Average values and one standard deviation obtained from three replicates.

${ }^{b}$ Average values and one standard deviation obtained from all data. 
Table H-14. Summary of drainable-water data for grouts prepared from Matrix 13

\begin{tabular}{lllllll}
\hline & \multicolumn{6}{c}{ Drainable water (vol \%) observed at } \\
\cline { 2 - 7 } Run No. & \multicolumn{7}{c}{$2 \mathrm{~h}$} & \multicolumn{1}{c}{$1 \mathrm{~d}$} & \multicolumn{1}{c}{$\mathbf{7 d}$} & $14 \mathrm{~d}$ & \multicolumn{1}{c}{$21 \mathrm{~d}$} & $28 \mathrm{~d}$ \\
\hline MX13-1 & $\mathbf{8 . 0 \pm 0 . 8}$ & $\mathbf{8 . 5} \pm 1.2$ & $6.9 \pm 1.0$ & $6.8 \pm 1.1$ & $6.8 \pm 1.1$ & $6.8 \pm 1.1$ \\
MX13-2 & $10.9 \pm 0.5$ & $11.9 \pm 0.6$ & $11.1 \pm 1.2$ & $10.8 \pm 1.4$ & $10.8 \pm 1.4$ & $10.8 \pm 1.4$ \\
MX13-3 & $\mathbf{8 . 3 \pm 0 . 5}$ & $\mathbf{8 . 9} \pm 0.8$ & $7.1 \pm 0.6$ & $6.9 \pm 0.5$ & $6.9 \pm 0.5$ & $6.9 \pm 0.5$ \\
MX13-4 & $6.9 \pm 0.5$ & $\mathbf{7 . 7} \pm 0.2$ & $6.7 \pm 0.5$ & $6.5 \pm 0.2$ & $6.3 \pm 0.5$ & $6.3 \pm 0.5$ \\
MX13-5 & $11.1 \pm 1.6$ & $13.3 \pm 0.9$ & $11.3 \pm 1.2$ & $11.3 \pm 1.2$ & $11.2 \pm 1.2$ & $11.2 \pm 1.2$ \\
MX13-6 & $7.5 \pm 0.5$ & $\mathbf{8 . 3} \pm 0.5$ & $6.4 \pm 0$ & $6.4 \pm 0$ & $6.4 \pm 0$ & $6.4 \pm 0$ \\
MX13-7 & $9.2 \pm 0.4$ & $10.3 \pm 0.2$ & $\mathbf{8 . 5} \pm 0.5$ & $\mathbf{8 . 4} \pm 0.4$ & $8.4 \pm 0.4$ & $8.4 \pm 0.4$ \\
MX13-8 & $10.3 \pm 0.5$ & $10.9 \pm 0.6$ & $9.1 \pm 1.0$ & $9.1 \pm 1.0$ & $9.1 \pm 1.0$ & $8.9 \pm 1.0$ \\
MX13-9 & $7.5 \pm 0.5$ & $\mathbf{8 . 3} \pm 0.2$ & $6.7 \pm 0.5$ & $6.7 \pm 0.5$ & $6.7 \pm 0.5$ & $6.7 \pm 0.5$ \\
& & & & & & \\
Average $^{b}$ & $\mathbf{8 . 8} \pm 1.6$ & $9.8 \pm 1.9$ & $\mathbf{8 . 2} \pm 2.0$ & $\mathbf{8 . 1} \pm 2.0$ & $\mathbf{8 . 1} \pm 2.0$ & $\mathbf{8 . 0} \pm 2.0$ \\
\hline
\end{tabular}

"Average values and one standard deviation obtained from three replicates.

${ }^{b}$ Average value and one standard deviation obtained from all data. 
Appendix I. AVERAGED UNCONFINED-COMPRESSIVE-STRENGTH DATA 
Table I-1. Summary of unconfined-compressivestrength values ${ }^{2}$ for grouts prepared from Matrix 1

\begin{tabular}{lc}
\hline $\begin{array}{l}\text { Run } \\
\text { No. }\end{array}$ & $\begin{array}{c}\text { Unconfined compressive strength } \\
\text { (psi) }\end{array}$ \\
\hline MX1-1 & $404 \pm 34$ \\
MX1-2 & $473 \pm 45$ \\
MX1-3 & $415 \pm 29$ \\
MX1-4 & $512 \pm 38$ \\
MX1-5 & $399 \pm 67$ \\
MX1-6 & $483 \pm 99$ \\
MX1-7 & $373 \pm 55^{c}$ \\
MX1-8 & $489 \pm 49$ \\
MX1-9 & $333 \pm 20$ \\
Average & $431 \pm 61$ \\
\hline
\end{tabular}

"Average values and one standard deviation obtained from nine replicates.

bAverage values and one standard deviation obtained from all data.

'Average values and one standard deviation obtained from seven replicates. 
Table 1.2. Summary of unconfined-compressivestrength values" for grouts prepared from Matrix 2

\begin{tabular}{lc}
\hline $\begin{array}{l}\text { Run } \\
\text { No. }\end{array}$ & $\begin{array}{c}\text { Unconfined compressive strength } \\
(\mathrm{psi})\end{array}$ \\
\hline MX2-1 & $439 \pm 28^{\mathrm{e}}$ \\
MX2-2 & $396 \pm 32$ \\
MX2.3 & $348 \pm 35$ \\
MX2-4 & $333 \pm 22$ \\
MX2-5 & $346 \pm 21$ \\
MX2-6 & $370 \pm 36$ \\
MX2-7 & $384 \pm 23$ \\
MX2-8 & $326 \pm 30$ \\
MX2-9 & $397 \pm 15^{d}$ \\
Averageb & $371 \pm 37$ \\
\hline
\end{tabular}

"Average values and one standard deviation obtained from nine replicates.

${ }^{b}$ Average values and one standard deviation obtained from all data.

'Average values and one standard deviation obtained from eight replicates.

Average values and one standard deviation obtained from seven replicates. 
Table 1.3. Summary of unconfined-compressivestrength values' for grouts prepared from Matrix 2R

\begin{tabular}{lc}
\hline $\begin{array}{l}\text { Run } \\
\text { No. }\end{array}$ & $\begin{array}{c}\text { Unconfined compressive strength } \\
\text { (psi) }\end{array}$ \\
\hline MX2R-1 & $391 \pm 46$ \\
MX2R-2 & $366 \pm 55$ \\
MX2R-3 & $371 \pm 50$ \\
MX2R-4 & $382 \pm 37$ \\
MX2R-5 & $379 \pm 30$ \\
MX2R-6 & $372 \pm 45$ \\
MX2R-7 & $329 \pm 26$ \\
MX2R-8 & $288 \pm 19$ \\
MX2R-9 & $265 \pm 19$ \\
Average & $349 \pm 45$ \\
\hline
\end{tabular}

Average values and one standard deviation obtained from nine replicates.

Average values and one standard deviation obtained from all data. 
Table 1-4. Summary of unconfined-compressive. strength values' for grouts prepared from Matrix 3

\begin{tabular}{|c|c|}
\hline $\begin{array}{l}\text { Run } \\
\text { No. }\end{array}$ & $\begin{array}{l}\text { Unconfined compreasive strengih } \\
\text { (pai) }\end{array}$ \\
\hline$M \times 3.1$ & $341 \neq 62$ \\
\hline$M \times 3.2$ & $306 \div 33$ \\
\hline$M \times 3.3$ & $351 \neq 53$ \\
\hline$M \times 3-4$ & $327 \div 20$ \\
\hline$M \times 3.5$ & $452 \div 20$ \\
\hline$M \times 3.6$ & $450 \div 15$ \\
\hline$M \times 3.7$ & $355 \div 17$ \\
\hline$M \times 3.8$ & $335 \div 26$ \\
\hline$M \times 3.9$ & $428 \div 13$ \\
\hline Averageb & $372 \div 56$ \\
\hline
\end{tabular}

'Average values and one standard deviation obtained from nine replicates.

-Average values and one standard deviation obtained from all data. 
Table 1.5. Summary of unconfined-compressivestrength values" for grouts prepared from Matrix 4

\begin{tabular}{|c|c|}
\hline $\begin{array}{l}\text { Run } \\
\text { No. }\end{array}$ & $\begin{array}{l}\text { Unconfined compressive strengih } \\
\text { (psi) }\end{array}$ \\
\hline MX4.1 & $492 \div 69$ \\
\hline$M \times 4-2$ & $500 \neq 40$ \\
\hline$M \times 4.3$ & $467 \div 62$ \\
\hline$M \times 4.4$ & $469 \div 31$ \\
\hline MX4.5 & $380 \div 22$ \\
\hline MX4.6 & $305 \div 28$ \\
\hline MX4.7 & $427 \div 19$ \\
\hline $\mathrm{MX} 4.8$ & $543=25$ \\
\hline$M \times 4.9$ & $312 \neq 41$ \\
\hline Averageb & $433 \div 84$ \\
\hline
\end{tabular}


Table 1-6. Summary of unconfined-compressivestrength values" for grouts prepared from Matrix 5

\begin{tabular}{lc}
\hline $\begin{array}{c}\text { Run } \\
\text { No. }\end{array}$ & $\begin{array}{c}\text { Unconfined compressive strength } \\
(p s i)\end{array}$ \\
\hline MXs.1 & $488 \pm 44$ \\
MXs.2 & $364 \pm 30$ \\
MXs.3 & $475 \pm 45$ \\
MXs.4 & $485 \pm 34$ \\
MXs.5 & $462 \pm 41$ \\
MXs.6 & $437 \pm 31^{\circ}$ \\
MXs.7 & $486 \pm 25$ \\
MXs.8 & $380 \pm 23$ \\
MXs.9 & $252 \pm 17$ \\
Average & $425 \pm 80$ \\
\hline
\end{tabular}

"Average values and one standard devlation obtained from nine replicates.

Average values and one standard deviation obtained from all data.

Average value and one standard deviation obtained from eight replicates. 
Table 1.7. Summary of unconfined-compressivestrength values" for grouts prepared from Matrix 6

\begin{tabular}{lc}
\hline $\begin{array}{l}\text { Run } \\
\text { No. }\end{array}$ & $\begin{array}{c}\text { Unconfined compressive strength } \\
(p s i)\end{array}$ \\
\hline MX6-1 & $602 \pm 42$ \\
MX6-2 & $612 \pm 84$ \\
MX6.3 & $449 \pm 40$ \\
MX6-4 & $398 \pm 22$ \\
MX6.5 & $448 \pm 76$ \\
MX6.6 & $443 \pm 87$ \\
MX6.7 & $481 \pm 30$ \\
MX6-8 & $336 \pm 35$ \\
MX6-9 & $488 \pm 40$ \\
Average & $473 \pm 89$
\end{tabular}

"Average values and one standard deviatlon obtained from nine replicates. 
Table 1-8. Summary of unconfined-compressivestrength values" for grouts prepared from Matrix 7

\begin{tabular}{lc}
\hline $\begin{array}{l}\text { Run } \\
\text { No. }\end{array}$ & $\begin{array}{c}\text { Unconfined compressive strength } \\
(\mathrm{psi})\end{array}$ \\
\hline MX6-1 & $430 \pm 44$ \\
MX6-2 & $443 \pm 21$ \\
MX6-3 & $383 \pm 30$ \\
MX6-4 & $236 \pm 22$ \\
MX6-5 & $367 \pm 29$ \\
MX6-6 & $465 \pm 35$ \\
MX6-7 & $280 \pm 22$ \\
MX6-8 & $450 \pm 21$ \\
MX6-9 & $337 \pm 23$ \\
Average & $377 \pm 80$ \\
\hline
\end{tabular}

${ }^{2}$ Average values and one standard deviation obtained from nine replicates.

${ }^{b}$ Average values and one standard deviation obtained from all data. 
Table I-9. Summary of unconfined-compressivestrength values * for grouts prepared from Matrix 8

\begin{tabular}{lc}
$\begin{array}{l}\text { Run } \\
\text { No. }\end{array}$ & $\begin{array}{c}\text { Unconfined compressive strength } \\
(\mathrm{psi})\end{array}$ \\
\hline MX8-1 & $451 \pm 53$ \\
MX8-2 & $421 \pm 34$ \\
MX8-3 & $403 \pm 28$ \\
MX8-4 & $392 \pm 48$ \\
MX8-5 & $297 \pm 24$ \\
MX8-6 & $234 \pm 31$ \\
MX8-7 & $315 \pm 35$ \\
MX8-8 & $489 \pm 52$ \\
MX8-9 & $470 \pm 50^{c}$ \\
Average & $386 \pm 86$ \\
\hline
\end{tabular}

Average values and one standard deviation obtained from nine replicates.

${ }^{b}$ Average values and one standard deviation obtained from all data.

${ }^{c}$ Average values and one standard deviation obtained from eight replicates. 
Table I-10. Summary of unconfined-compressivestrength values" for grouts prepared from Matrix 9

\begin{tabular}{lc}
\hline $\begin{array}{l}\text { Run } \\
\text { No. }\end{array}$ & $\begin{array}{c}\text { Unconfined compressive strength } \\
(\mathrm{psi})\end{array}$ \\
\hline MX9-1 & $475 \pm 144$ \\
MX9-2 & $417 \pm 35$ \\
MX9-3 & $362 \pm 85$ \\
MX9-4 & $388 \pm 39$ \\
MX9-5 & $367 \pm 32$ \\
MX9-6 & $393 \pm 47$ \\
MX9-7 & $448 \pm 23$ \\
MX9-8 & $269 \pm 33^{c}$ \\
MX9-9 & $369 \pm 23$ \\
Average & $388 \pm 59$ \\
\hline
\end{tabular}

${ }^{2}$ Average values and one standard deviation obtained from nine replicates.

${ }^{b}$ Average values and one standard deviation obtained from all data.

${ }^{c}$ Average values and one standard deviation obtained from eight replicates. 
Table I-11. Summary of unconfined-compressivestrength values" for grouts prepared

from Matrix 10

\begin{tabular}{lc}
\hline $\begin{array}{l}\text { Run } \\
\text { No. }\end{array}$ & $\begin{array}{c}\text { Unconfined compressive strength } \\
(\mathrm{psi})\end{array}$ \\
\hline MX10-1 & $377 \pm 55$ \\
MX10-2 & $410 \pm 46$ \\
MX10-3 & $412 \pm 21^{\mathrm{c}}$ \\
MX10-4 & $439 \pm 40$ \\
MX10-5 & $329 \pm 28^{c}$ \\
MX10-6 & $353 \pm 62$ \\
MX10-7 & $511 \pm 45$ \\
MX10-8 & $674 \pm 32$ \\
MX10-9 & $371 \pm 39$ \\
\hline Average & $431 \pm 106$ \\
\hline
\end{tabular}

Average values and one standard deviation obtained from nine replicates.

bAverage values and one standard deviation obtained from all data.

${ }^{c}$ Average values and one standard deviation obtained from eight replicates. 
Table I-12. Summary of unconfined-compressivestrength values" for grouts prepared from Matrix 11

\begin{tabular}{lc}
\hline $\begin{array}{l}\text { Run } \\
\text { No. }\end{array}$ & $\begin{array}{c}\text { Unconfined compressive strength } \\
(\mathrm{psi})\end{array}$ \\
\hline MX11-1 & $510 \pm 75$ \\
MX11-2 & $657 \pm 54$ \\
MX11-3 & $618 \pm 62$ \\
MX11-4 & $375 \pm 43$ \\
MX11-5 & $368 \pm 32$ \\
MX11-6 & $386 \pm 61$ \\
MX11-7 & $828 \pm 32$ \\
MX11-8 & $829 \pm 59$ \\
MX11-9 & $645 \pm 110$ \\
Average ${ }^{b}$ & $579 \pm 183$ \\
\hline
\end{tabular}

Average values and one standard deviation obtained from nine replicates.

${ }^{b}$ Average values and one standard deviation obtained from all data. 
Table 1-13. Summary of unconfined-compressivestrength values" for grouts prepared from Matrix 12

\begin{tabular}{lc}
\hline $\begin{array}{l}\text { Run } \\
\text { No. }\end{array}$ & $\begin{array}{c}\text { Unconfined compressive strength } \\
(\mathrm{psi})\end{array}$ \\
\hline MX12-1 & $554 \pm 49^{c}$ \\
MX12-2 & $517 \pm 49$ \\
MX12-3 & $494 \pm 46$ \\
MX12-4 & $491 \pm 35$ \\
MX12-5 & $597 \pm 77$ \\
MX12-6 & $587 \pm 49$ \\
MX12-7 & $603 \pm 45^{c}$ \\
MX12-8 & $424 \pm 22$ \\
MX12-9 & $488 \pm 28^{c}$ \\
Average & $527 \pm 73$ \\
\hline
\end{tabular}

"Average values and one standard deviation obtained from nine replicates.

${ }^{b}$ Average values and one standard deviation obtained from all data.

'Average values and one standard deviation obtained from eight replicates. 
Table I-14. Summary of unconfined-compressivestrength values" for grouts prepared from Matrix 13

\begin{tabular}{lc}
\hline $\begin{array}{l}\text { Run } \\
\text { No. }\end{array}$ & $\begin{array}{c}\text { Unconfined compressive strength } \\
(\mathrm{psi})\end{array}$ \\
\hline MX13-1 & $484 \pm 86$ \\
MX13-2 & $525 \pm 44$ \\
MX13-3 & $446 \pm 54$ \\
MX13-4 & $610 \pm 62$ \\
MX13-5 & $480 \pm 18$ \\
MX13-6 & $497 \pm 43$ \\
MX13-7 & $511 \pm 39$ \\
MX13-8 & $433 \pm 30$ \\
MX13-9 & $436 \pm 41$ \\
Average & $491 \pm 71$ \\
\hline
\end{tabular}

Average values and one standard deviation obtained from nine replicates.

${ }^{b}$ Average values and one standard deviation obtained from all data. 


\section{Appendix J. STATISTICAL COMPARISON OF AVERAGE DATA OBTAINED ON REFERENCE FORMULATTON}

The data are presented in number-line form for ease of comparison. On the number line, the ordinate values are arbitrary to factlitate visual inspection. If any two points are separated by the minimum distance on the number line, then they are statistically different. The minimum distance is determined by the "Q-test." 


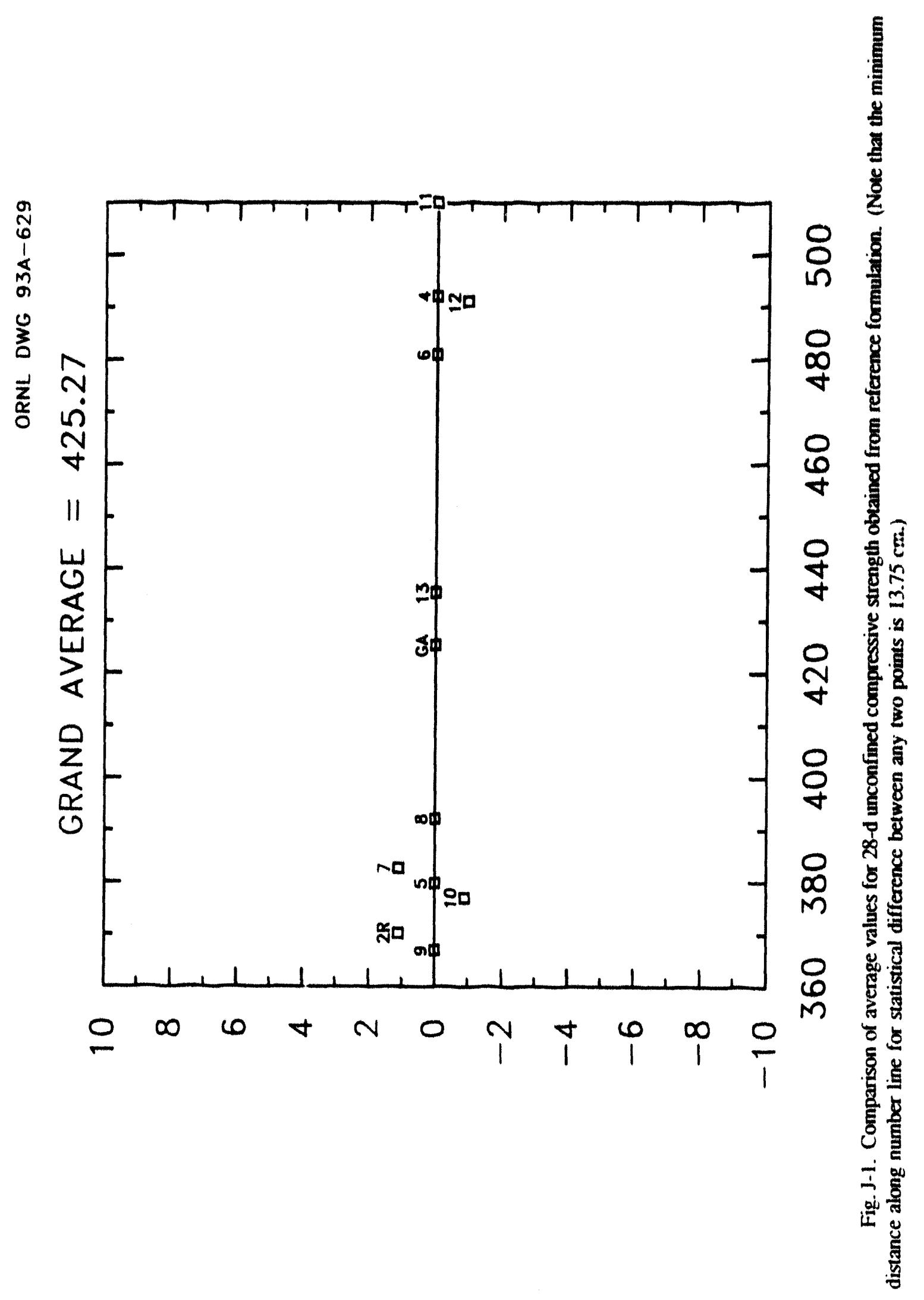




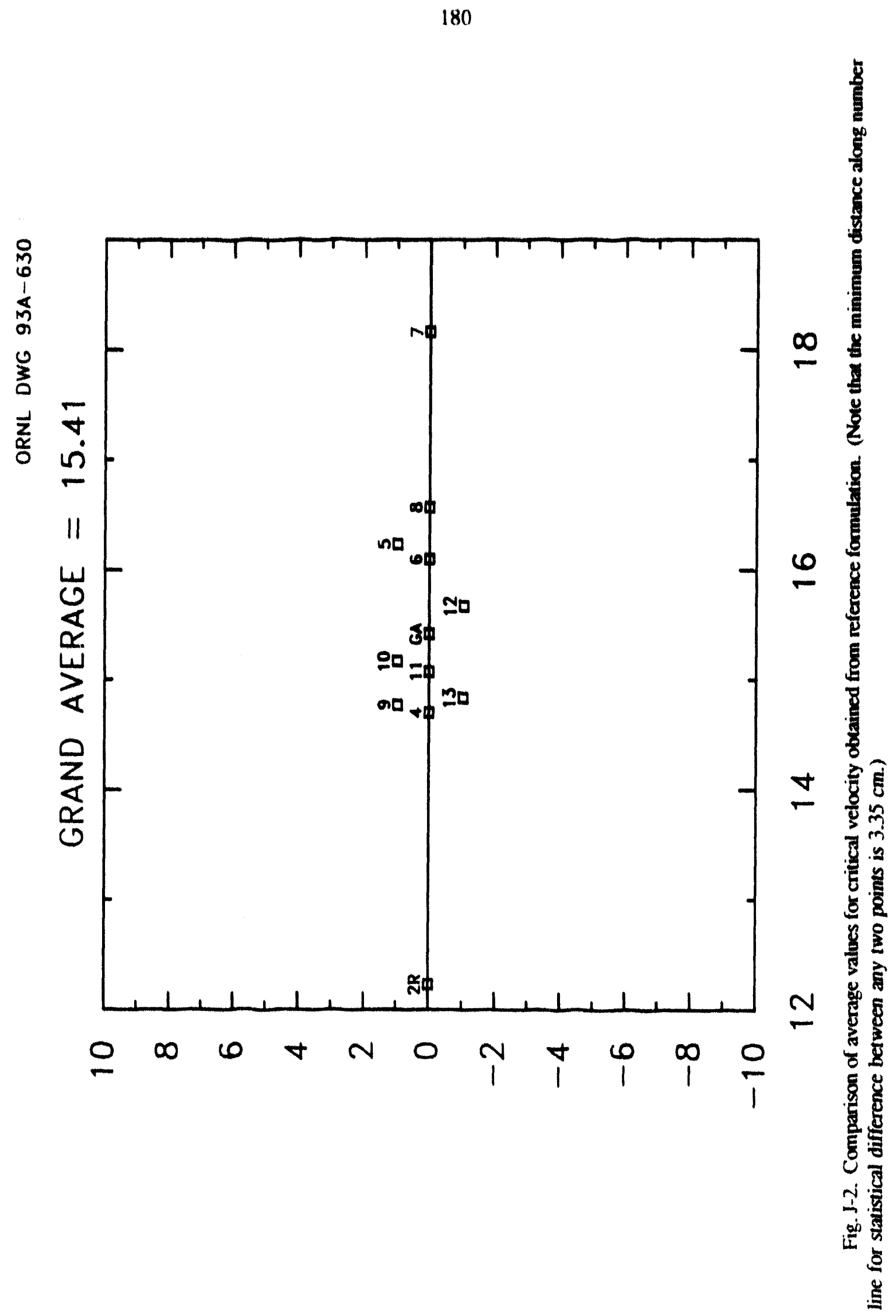




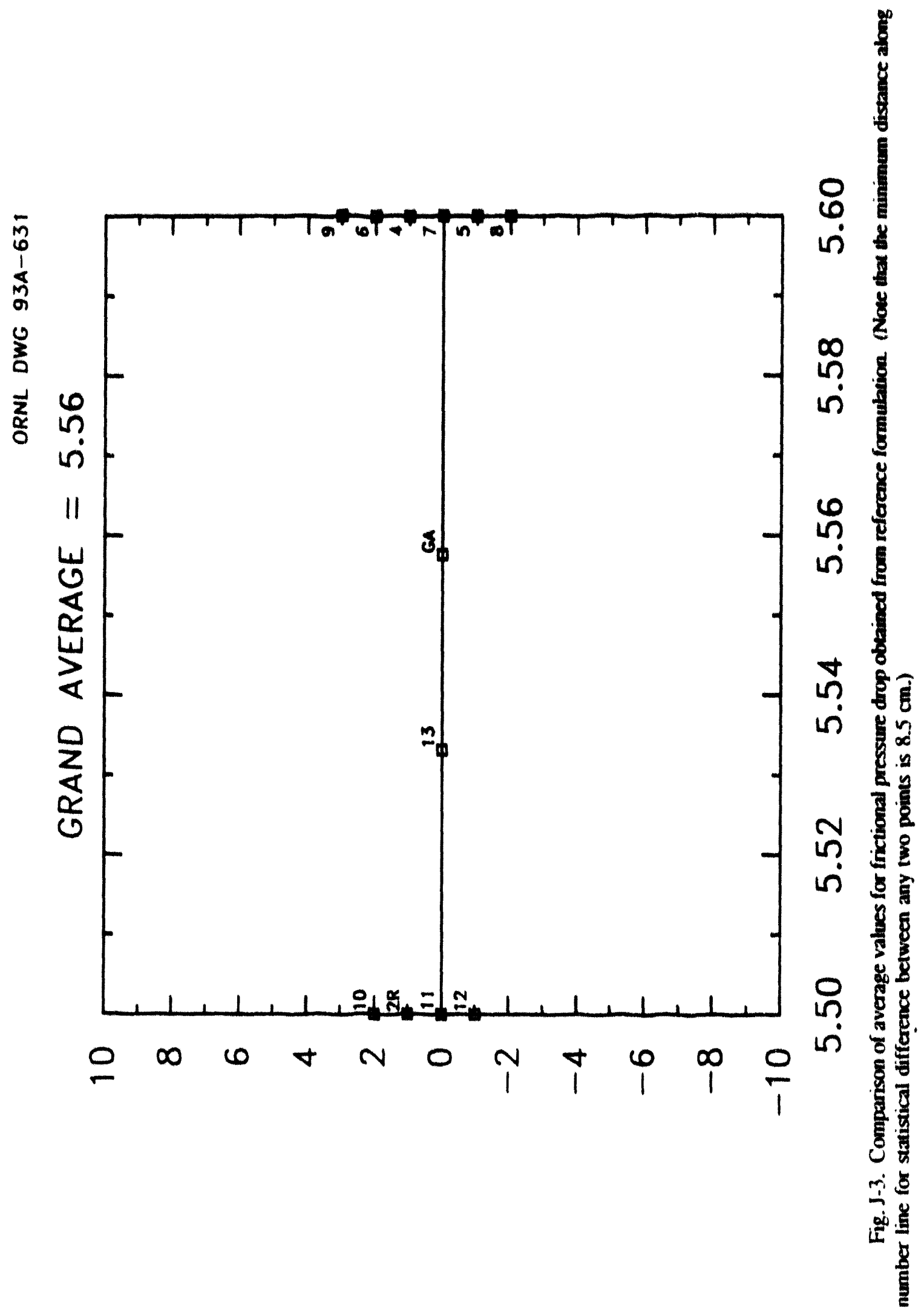




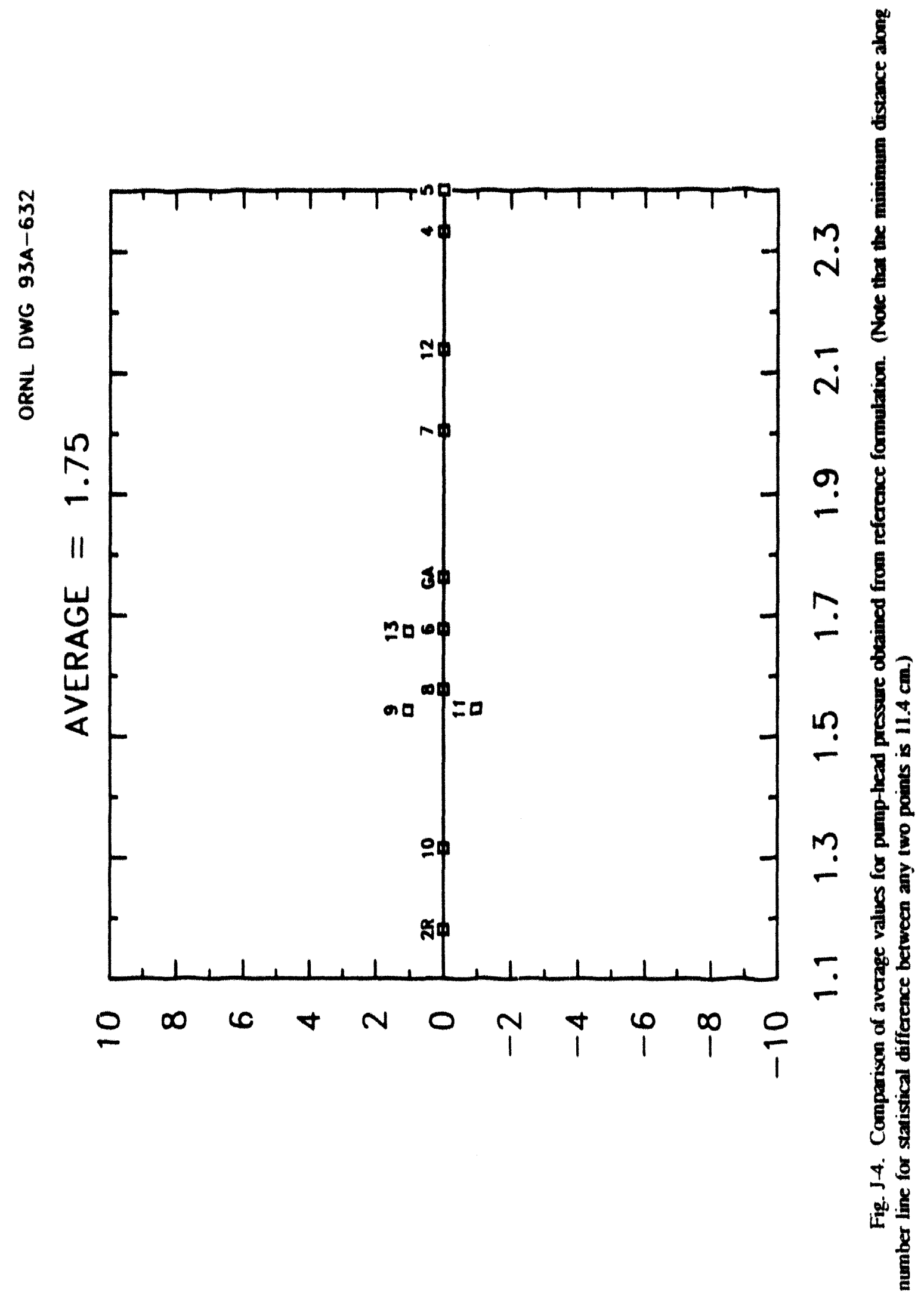




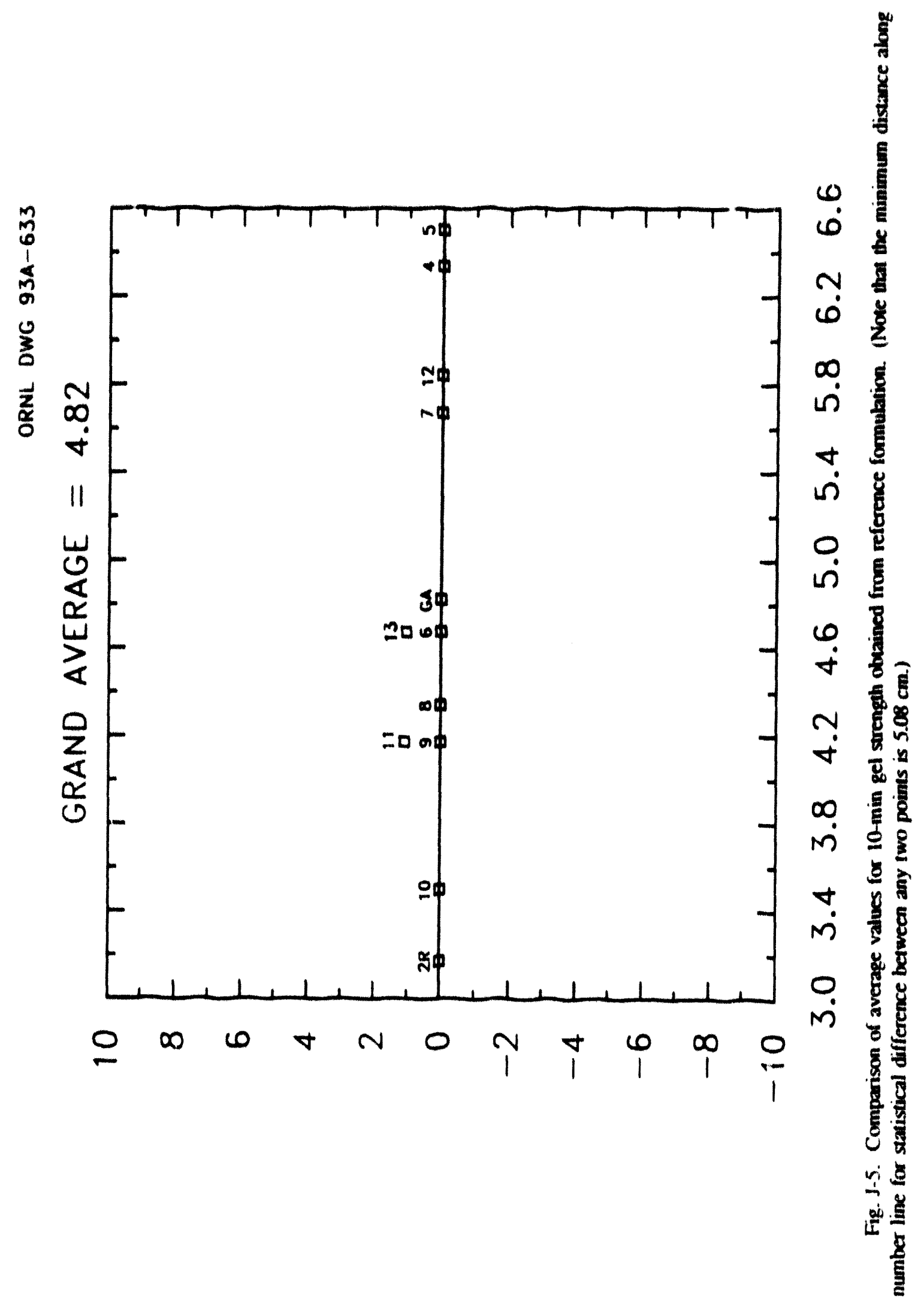




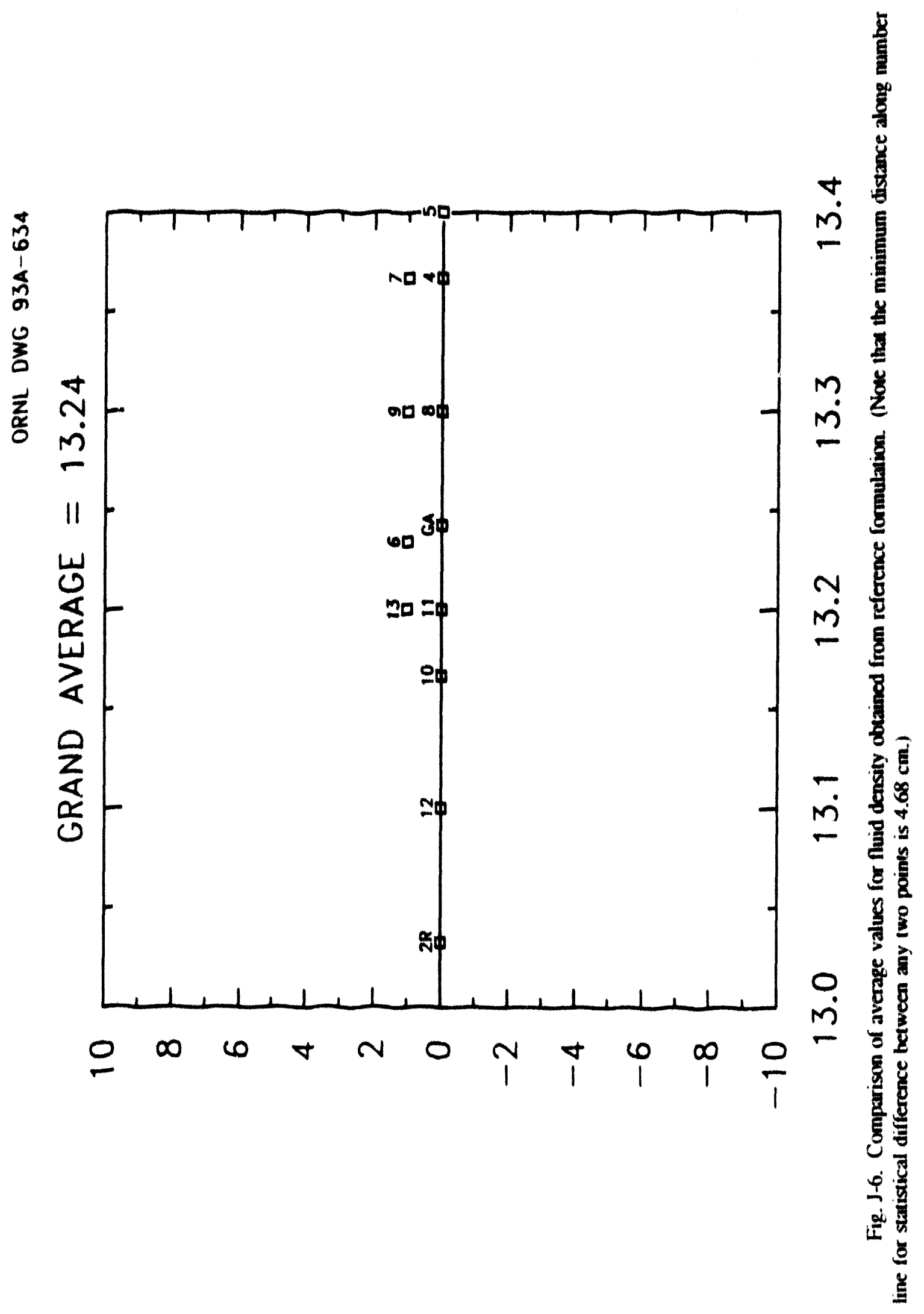




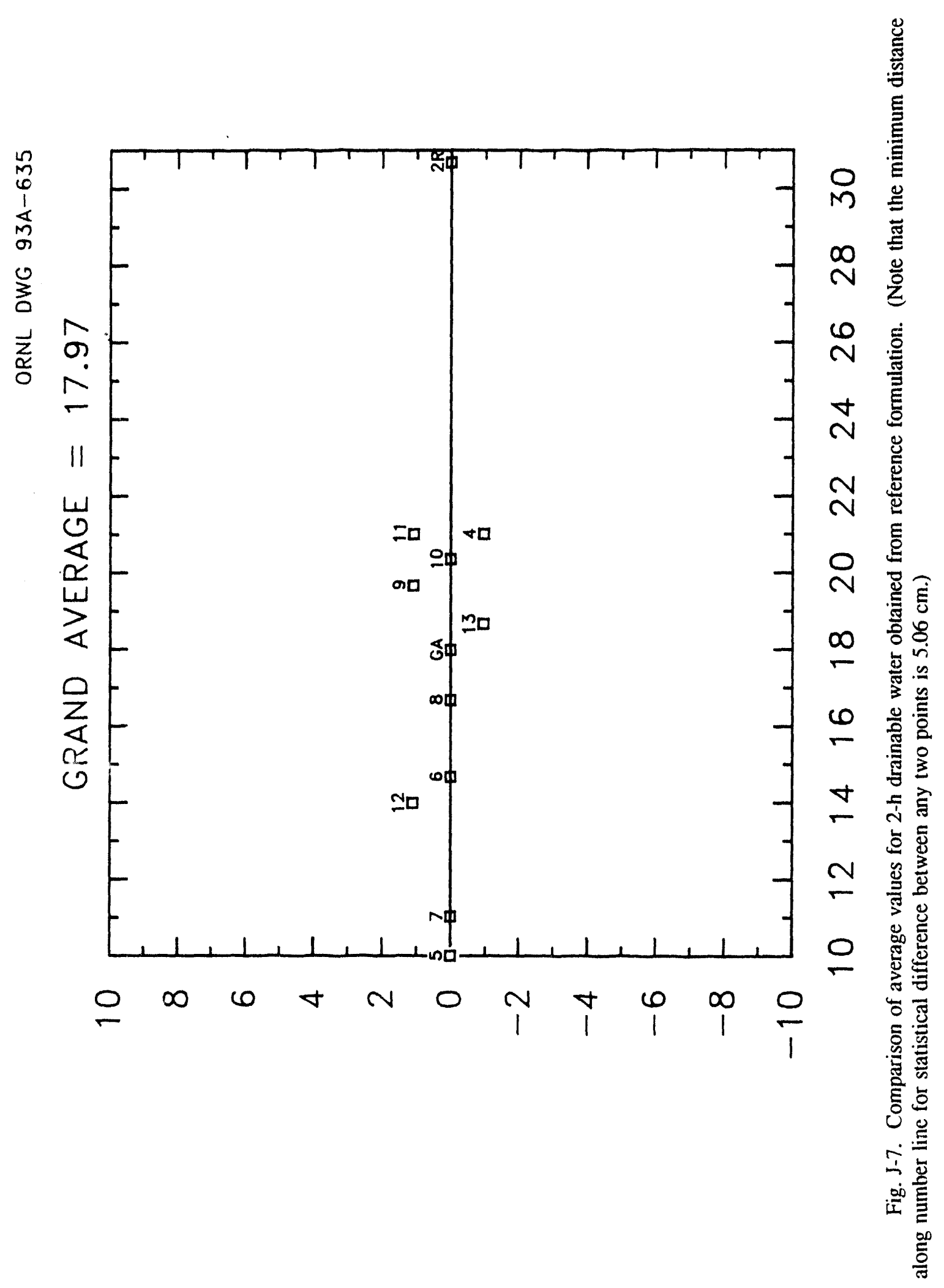




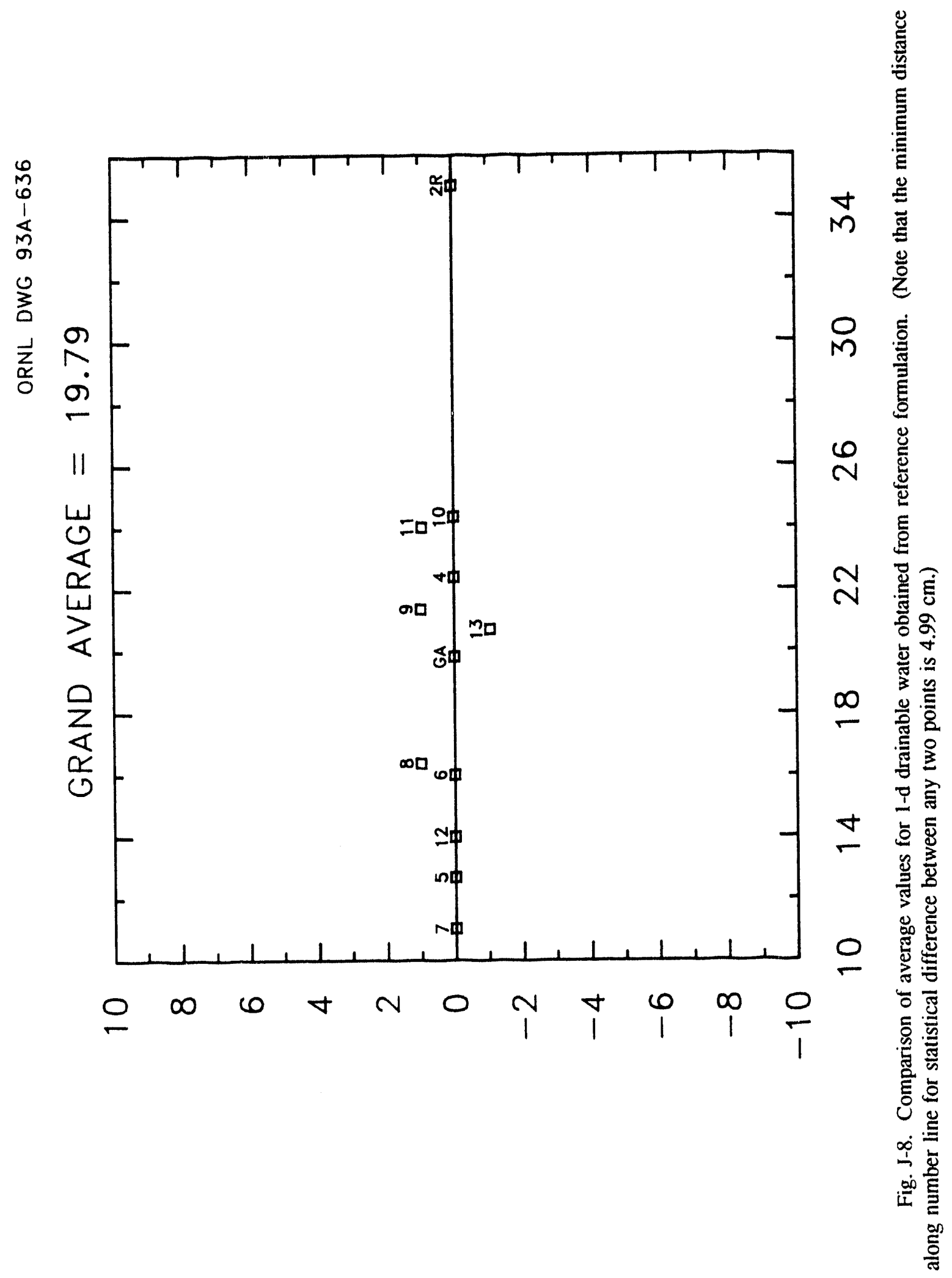




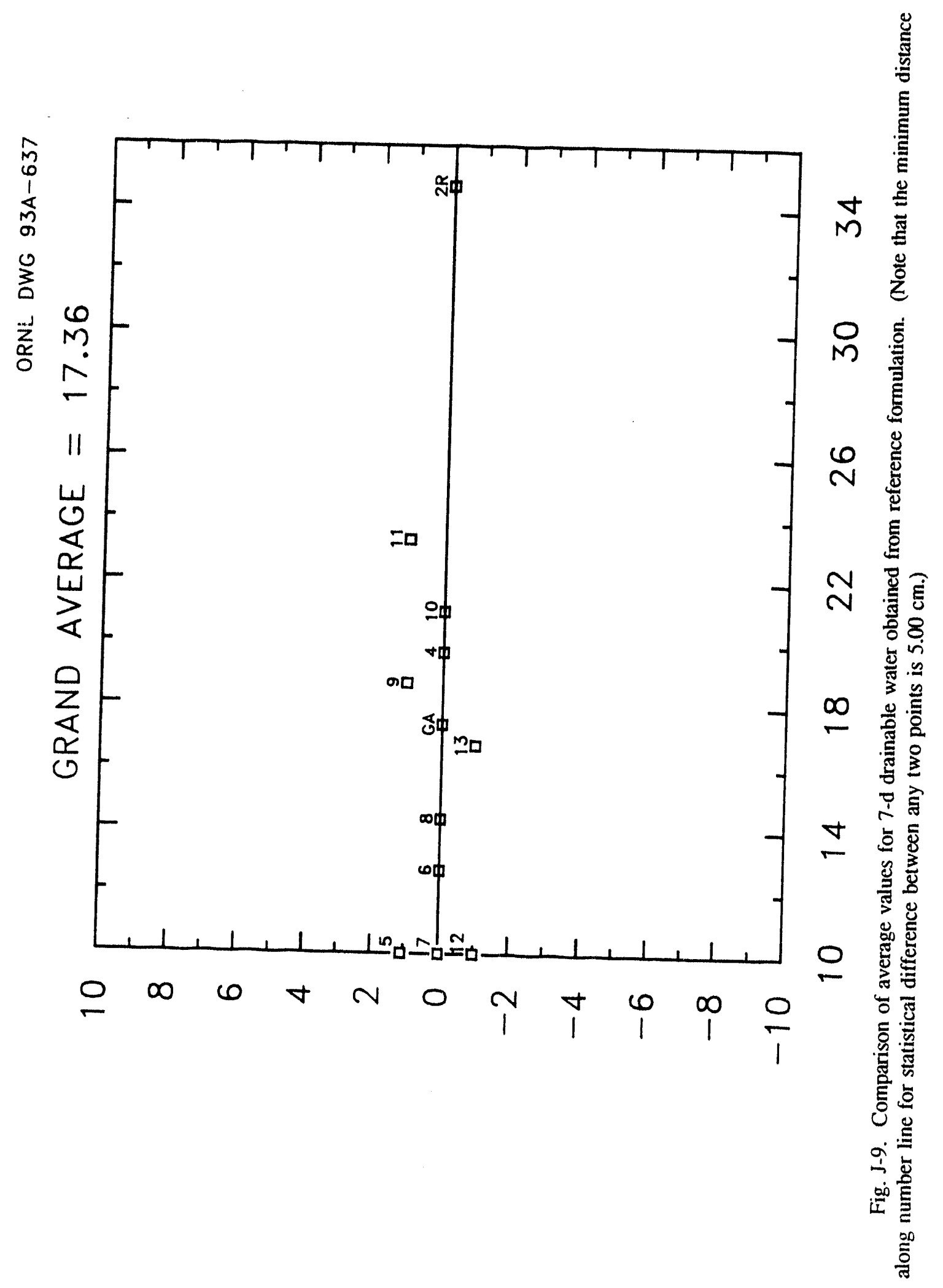




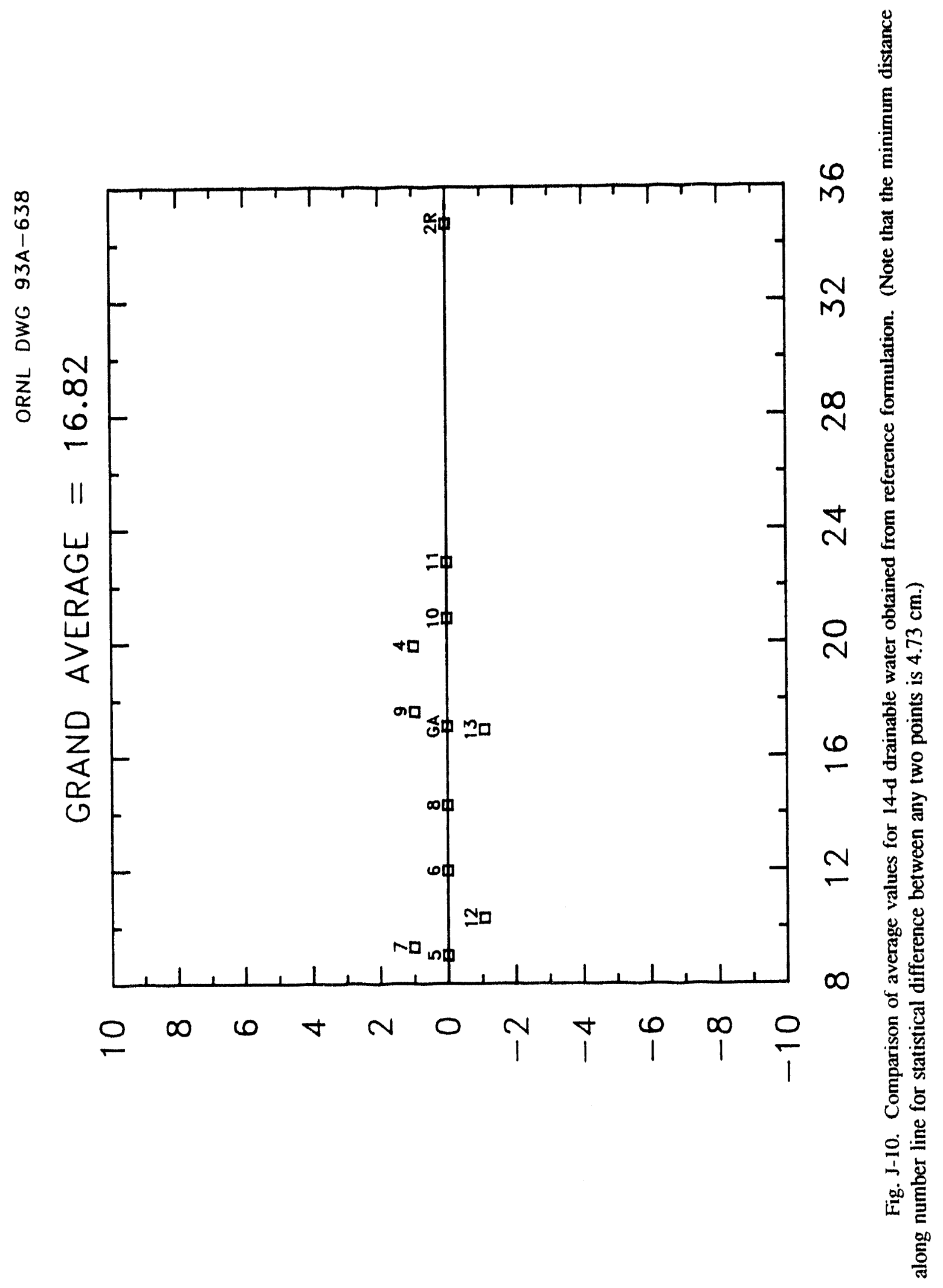




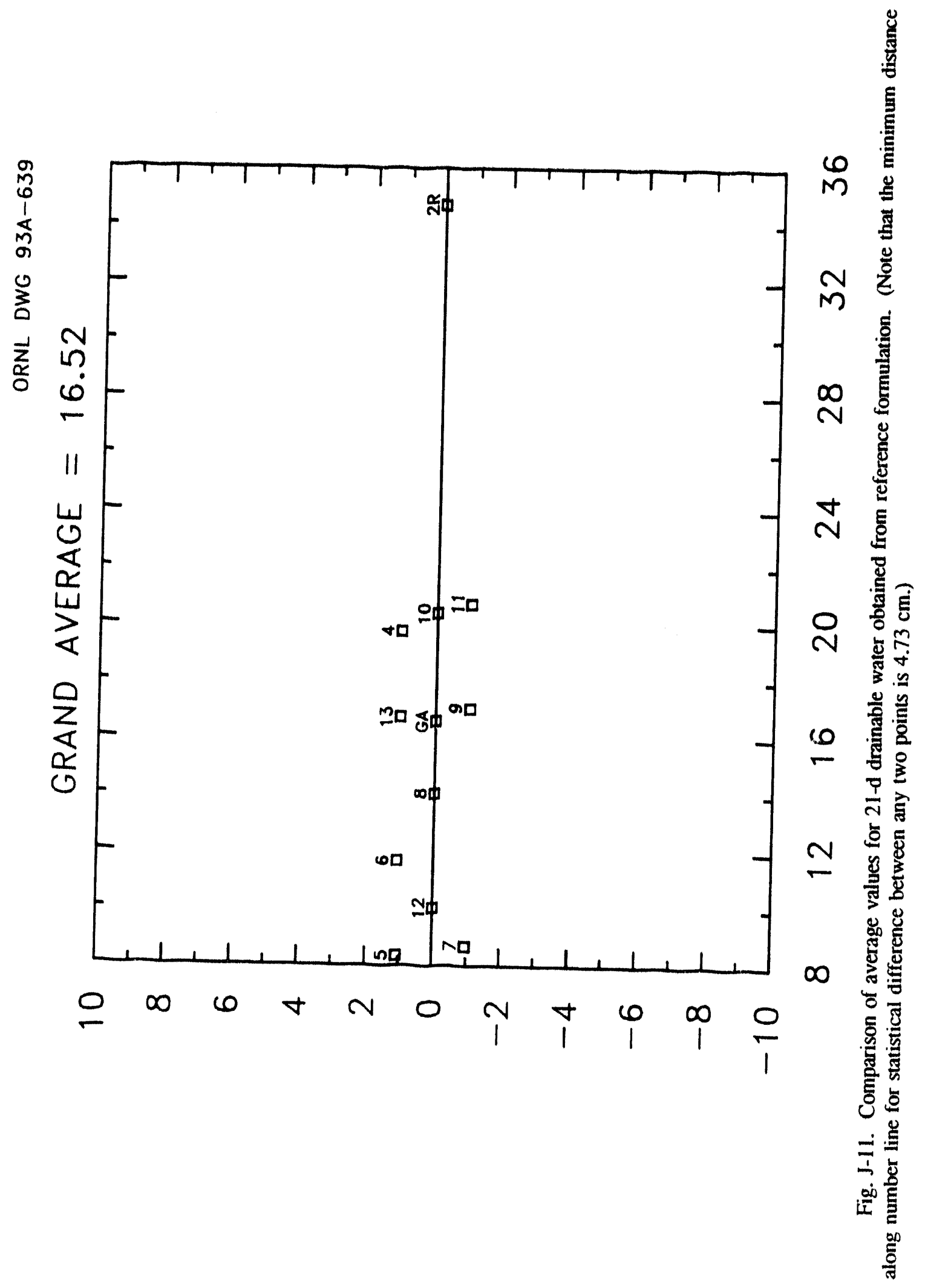




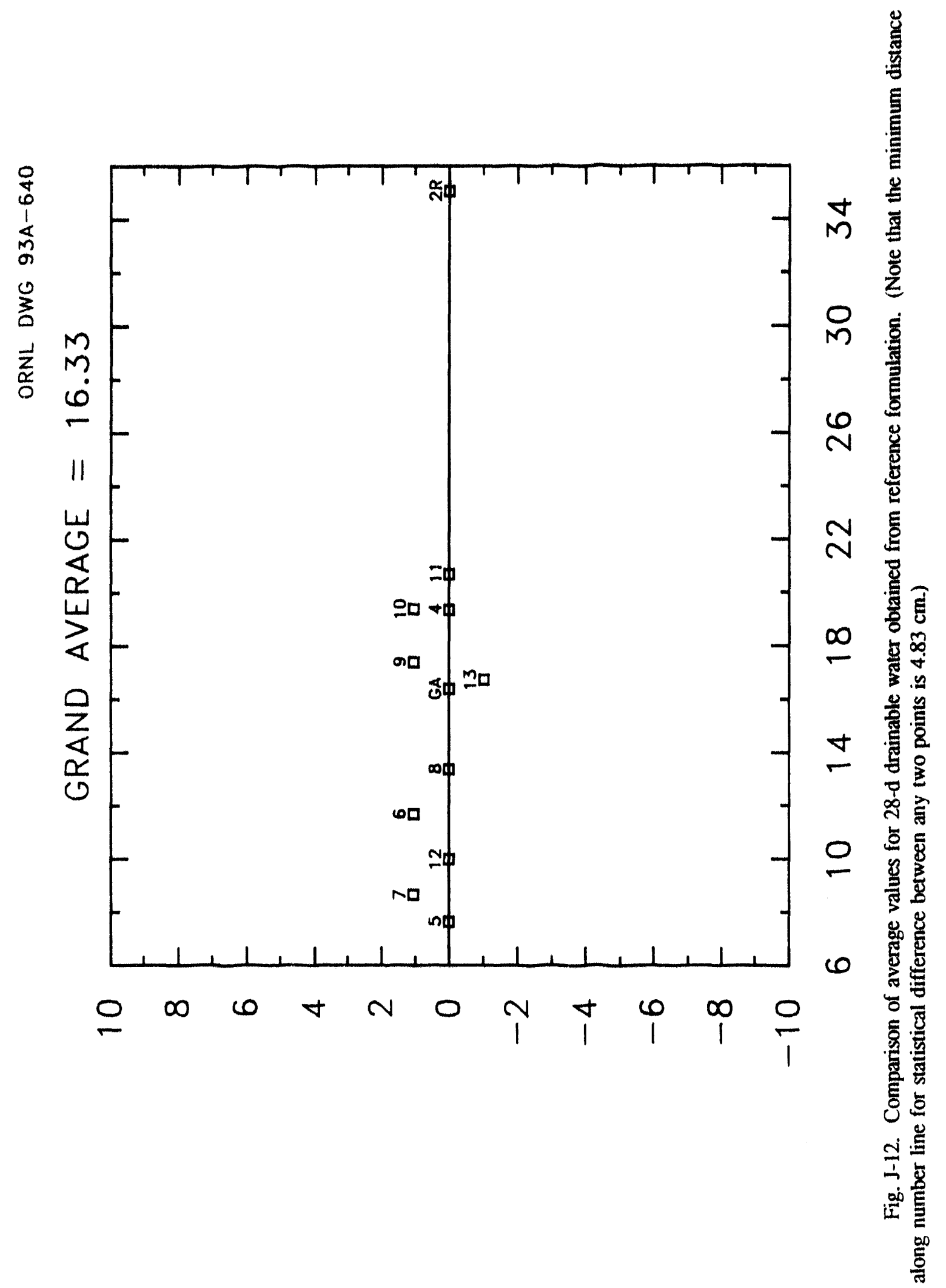




\section{Appendix K STATISTICAL, COMPARISON OF DATA OBTAINED BY AVERAGING ALL VALUES WITHIN A MATRIX}

The data are presented in number-line form for ease of comparison. On the number line, the ordinate values are arbitrary to faclitate visual inspection. If any two points are separated by the minimum distance along the number line, then they are statistically different. The minimum distance is determined by the "Q-test." 


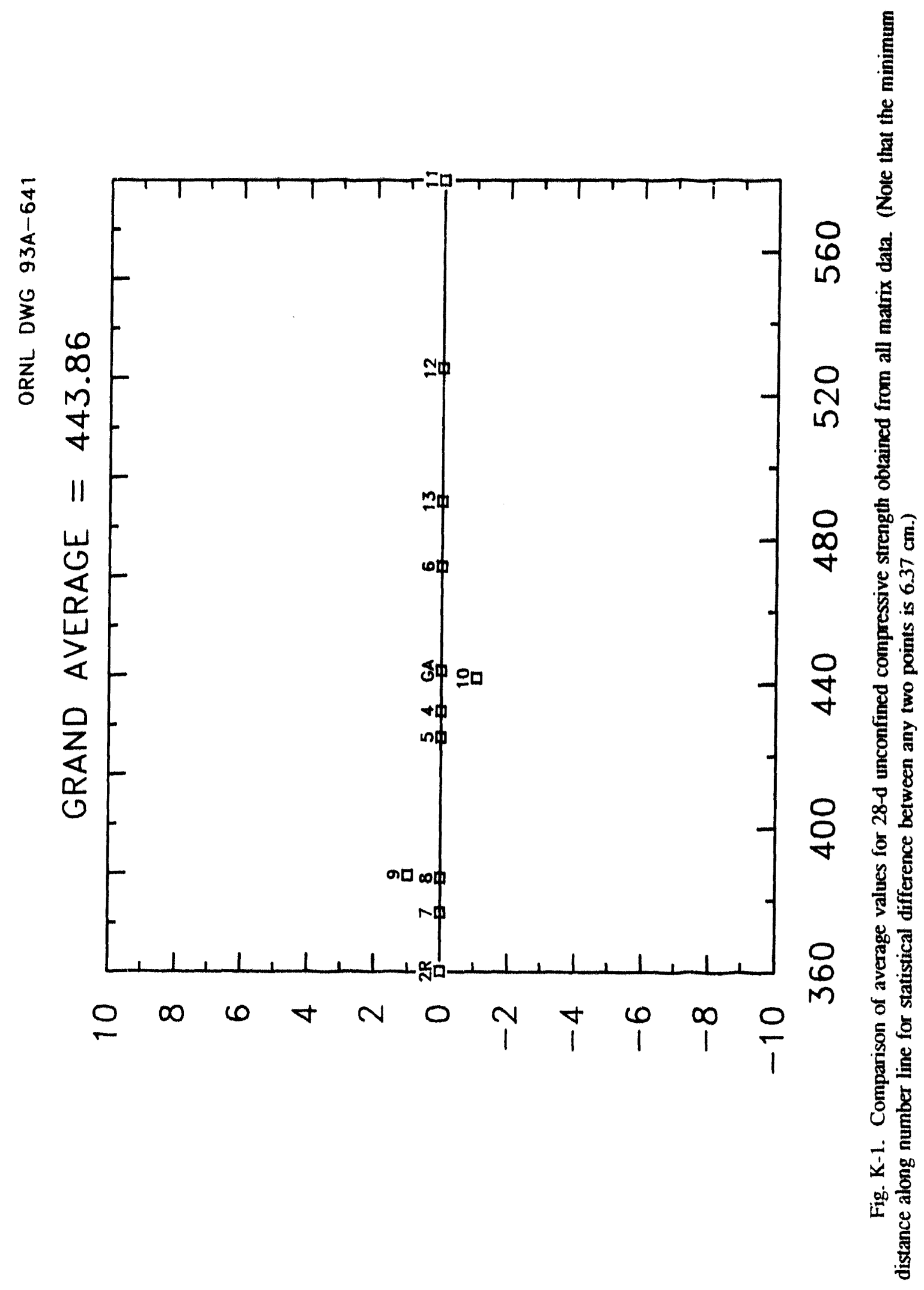




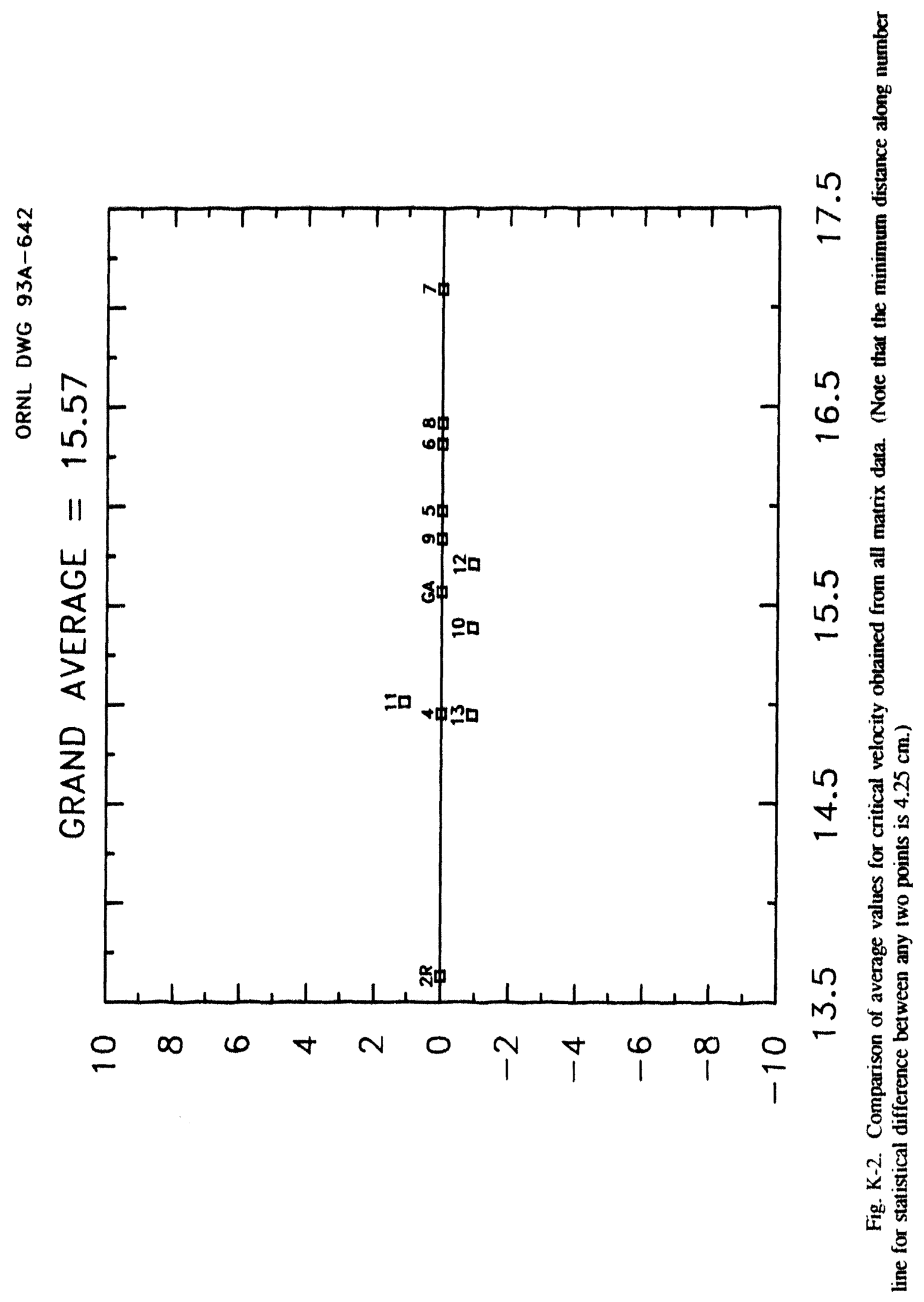




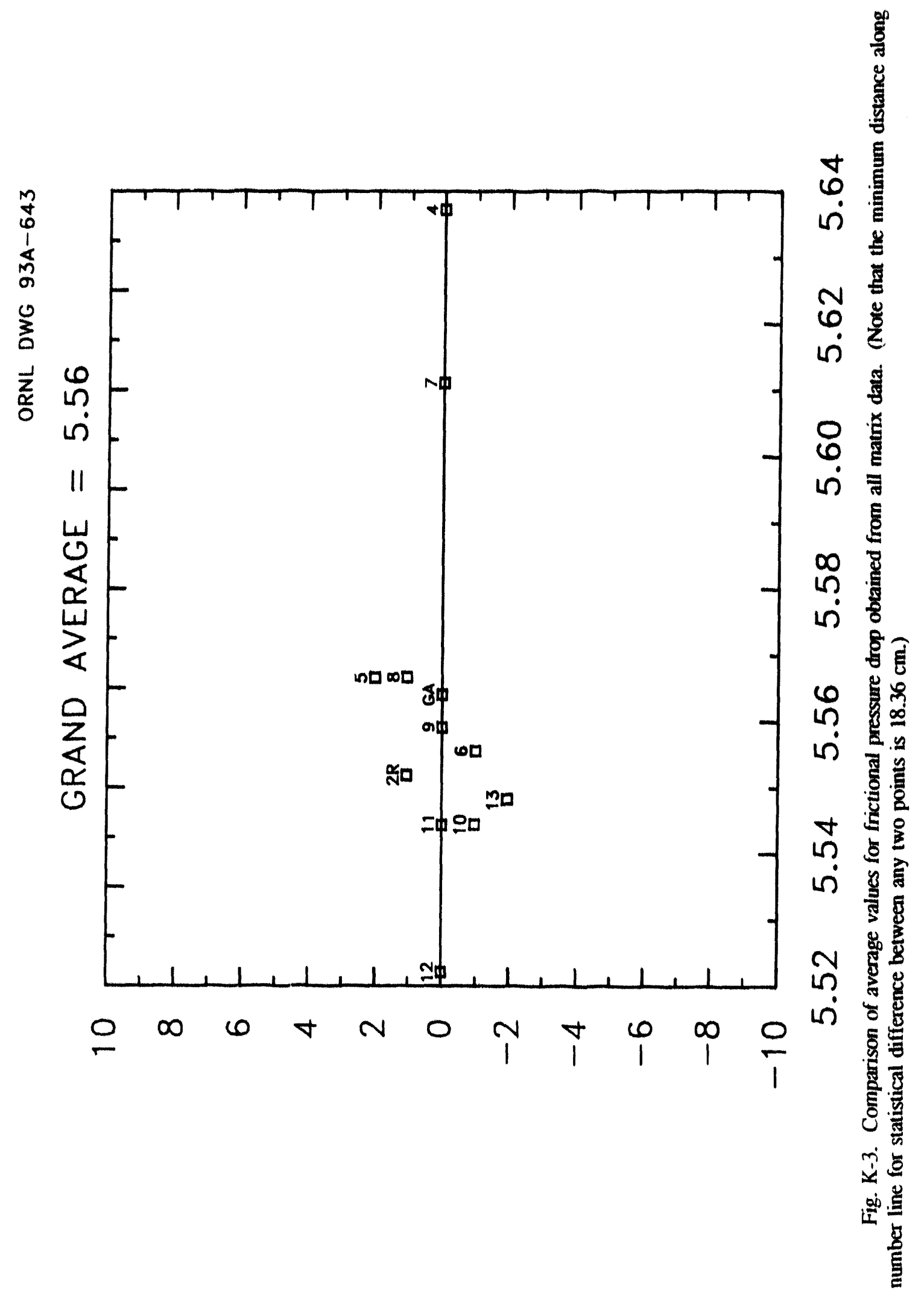




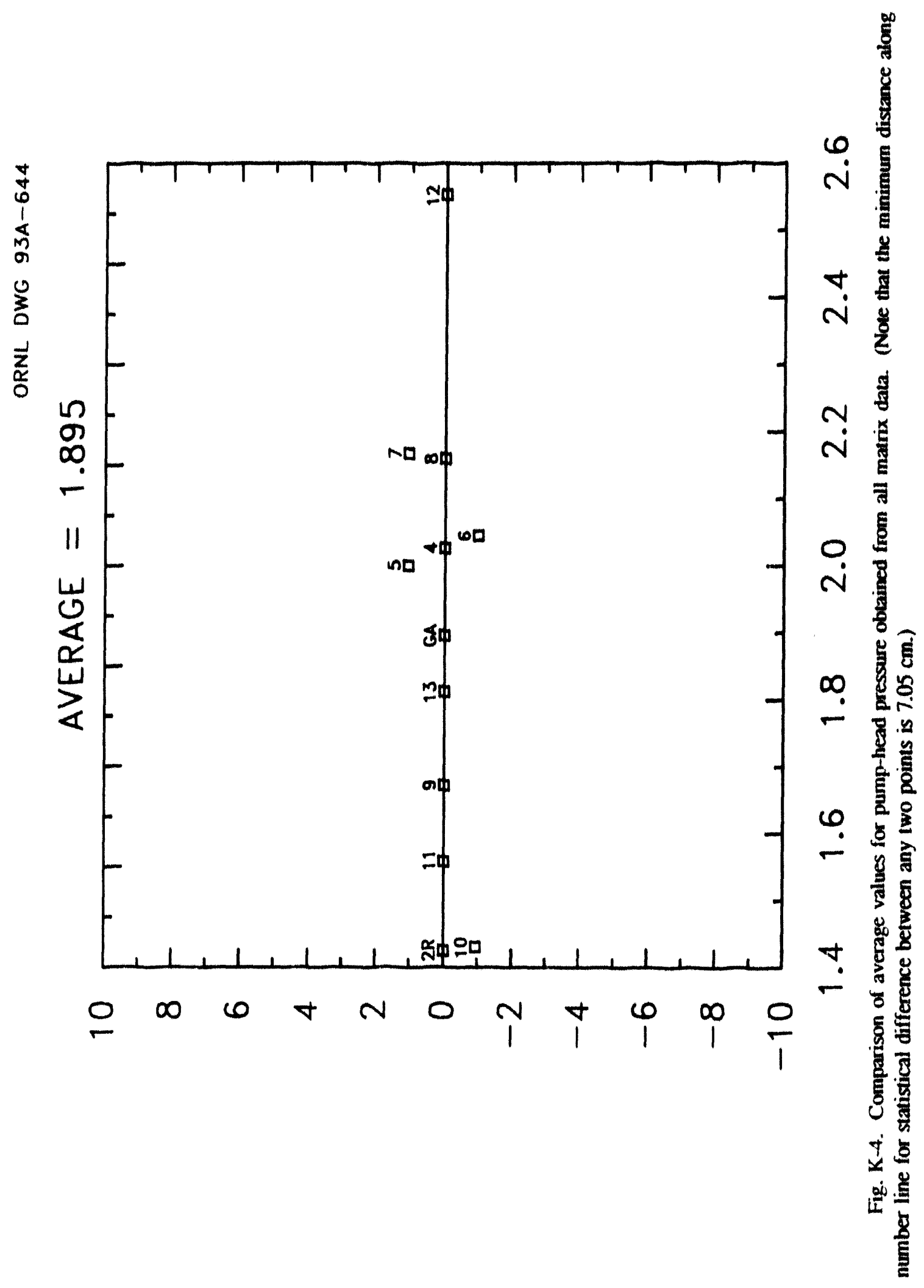




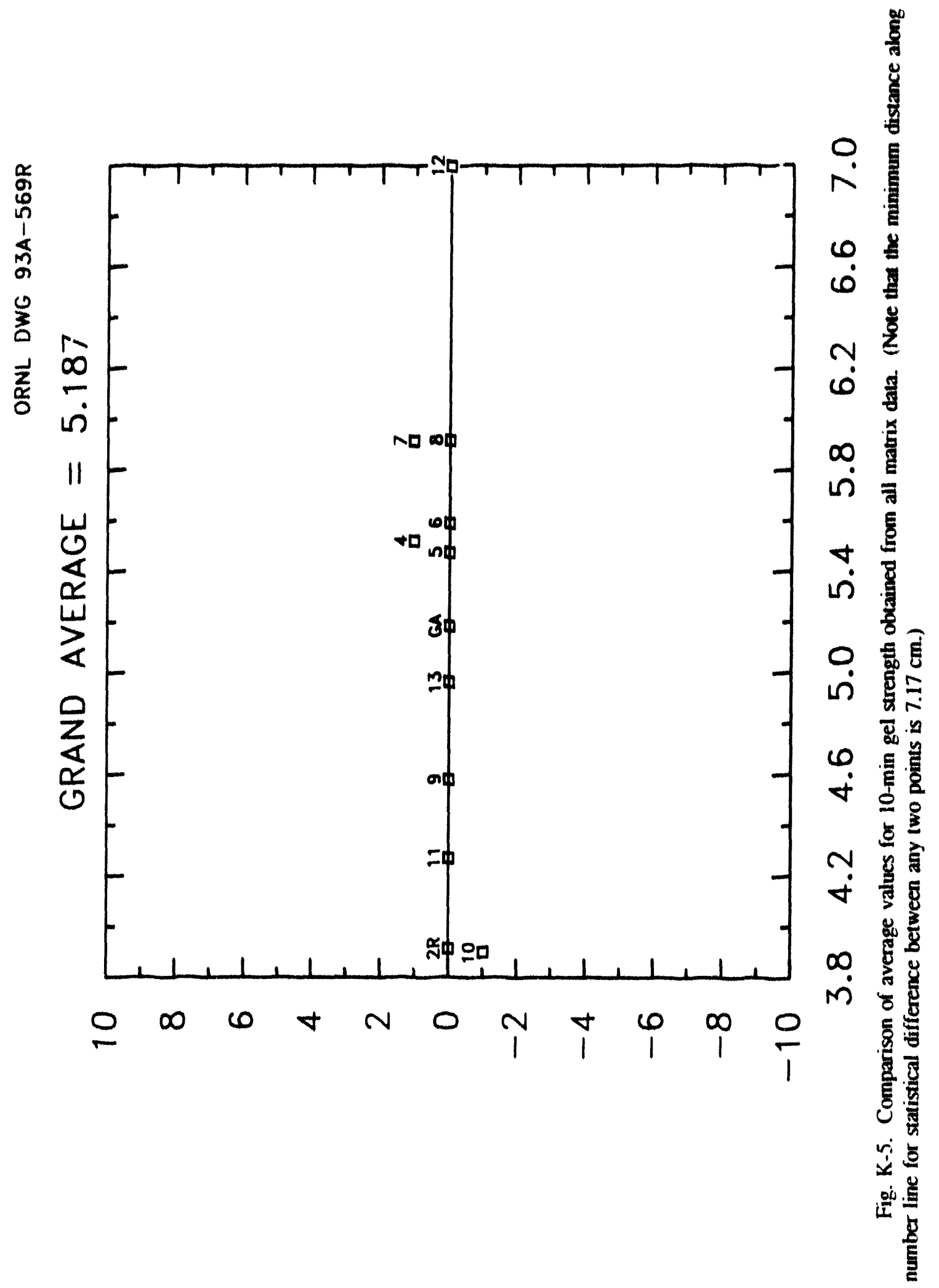




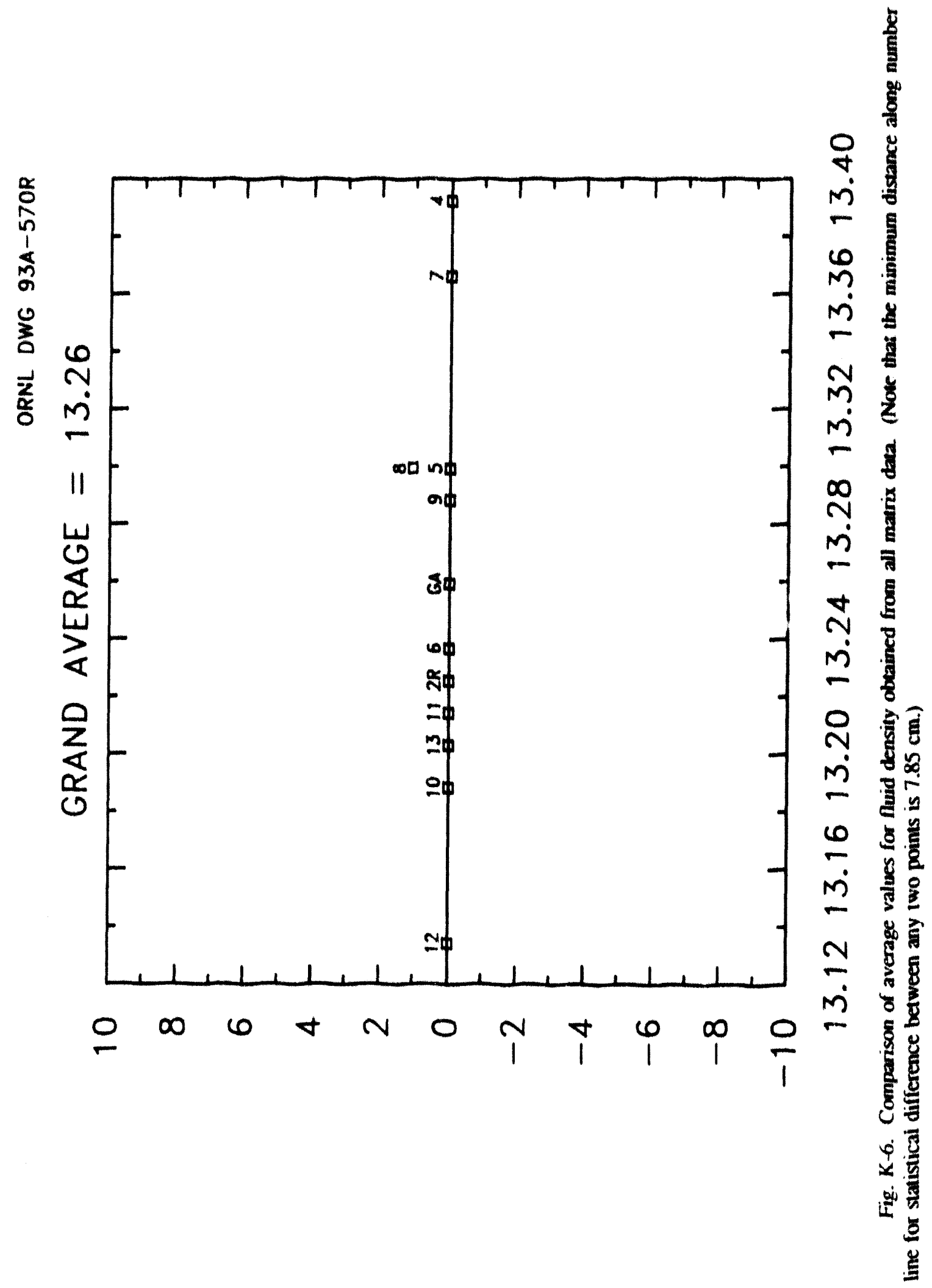




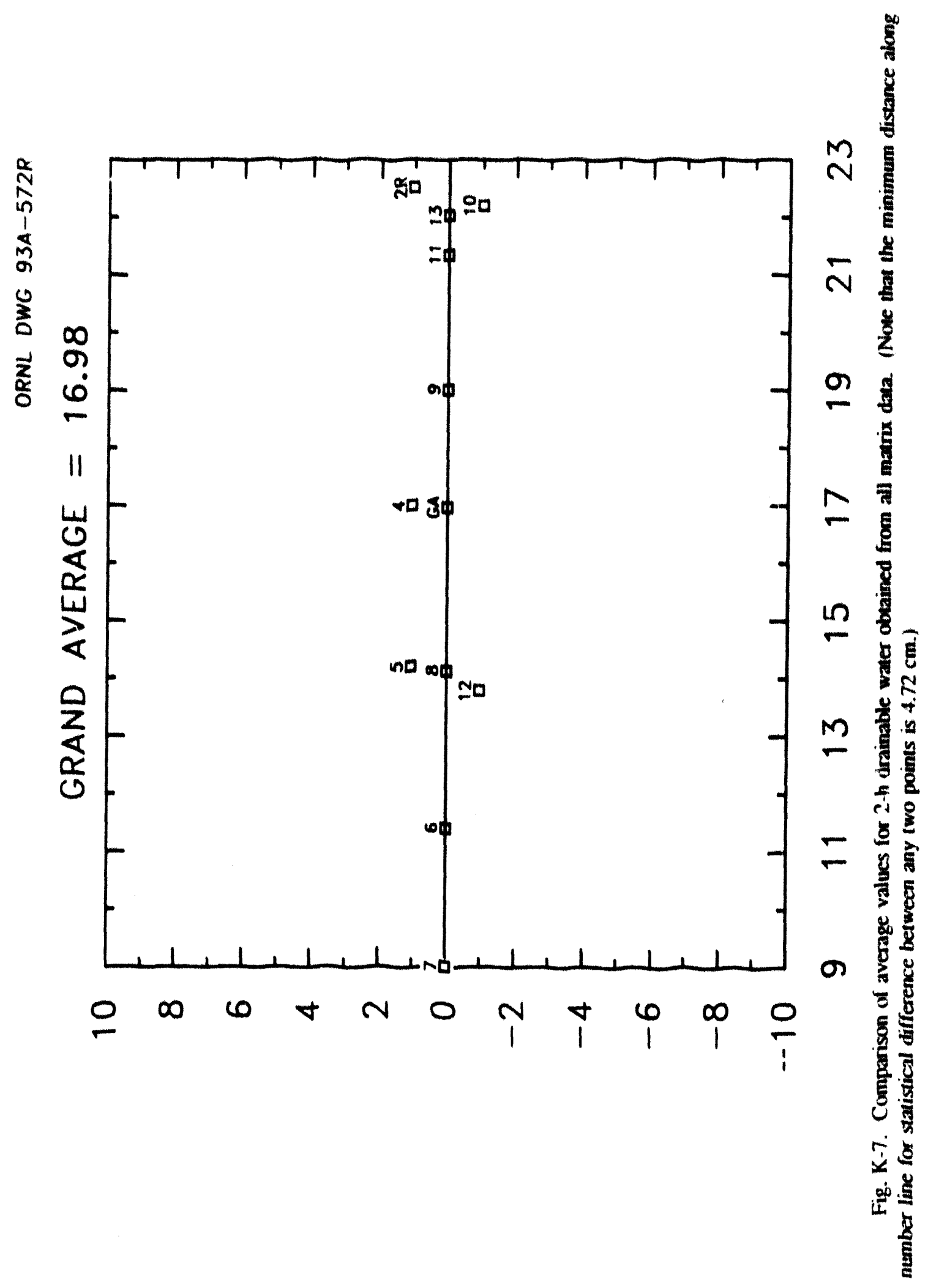




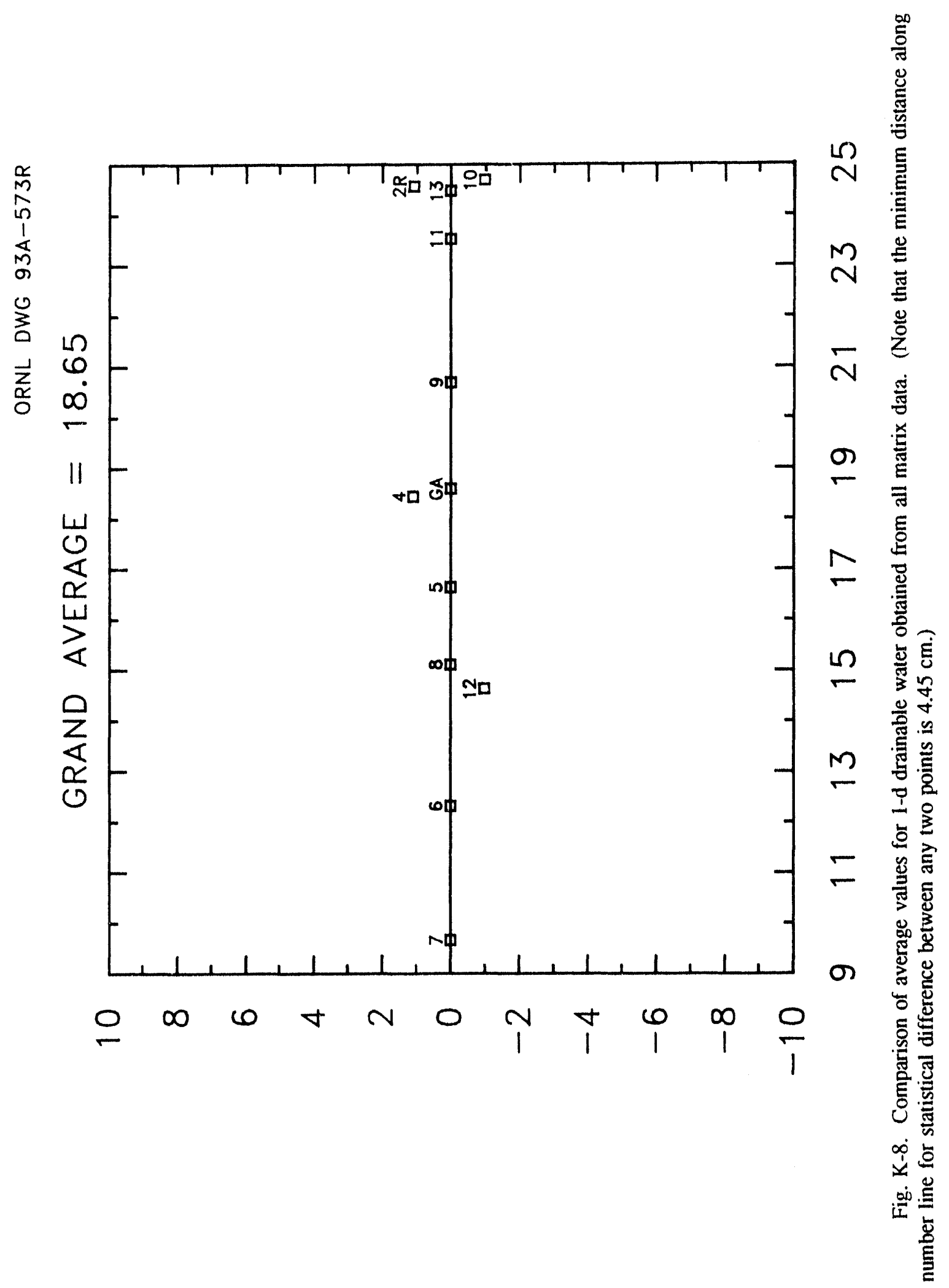




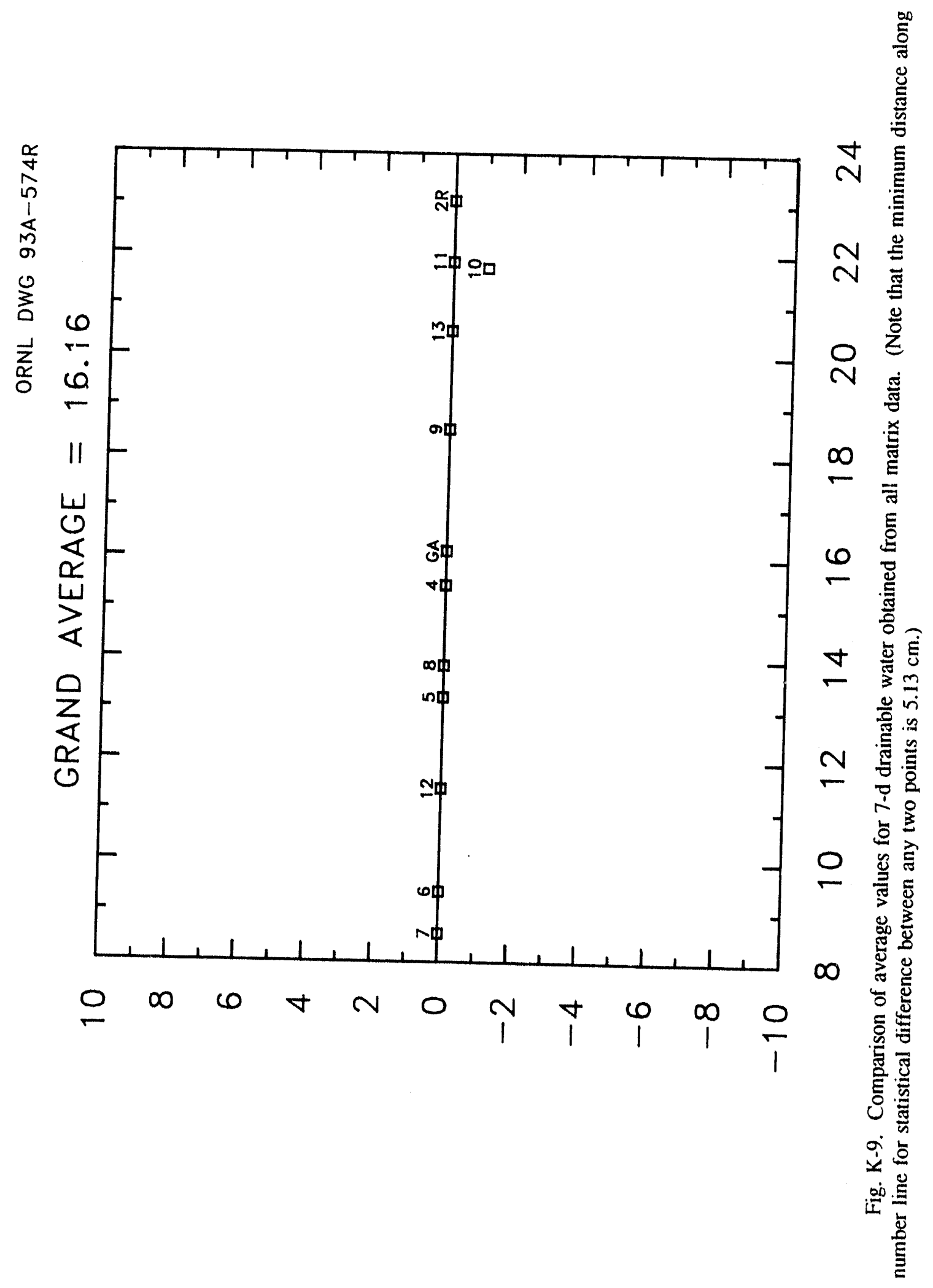




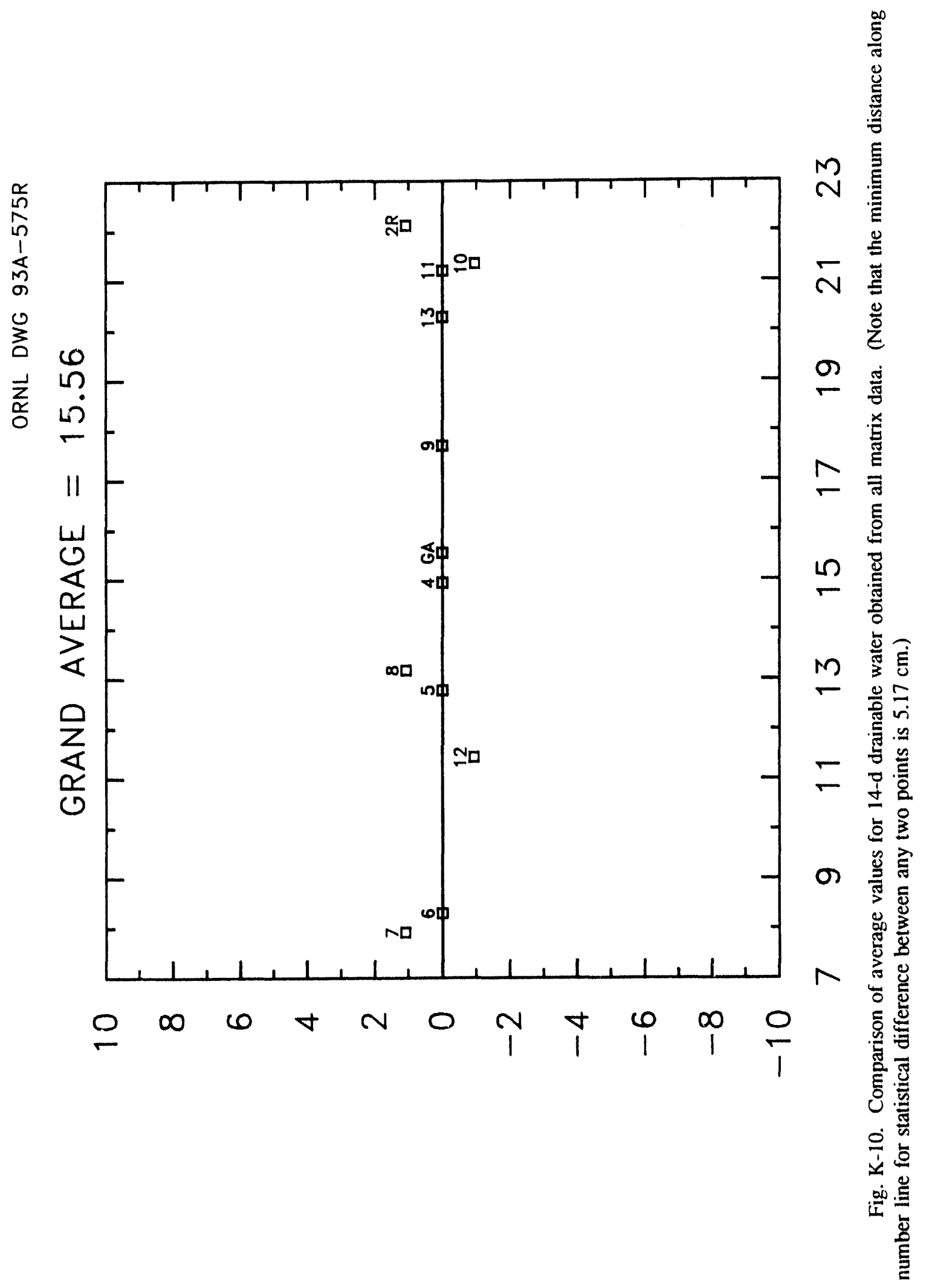




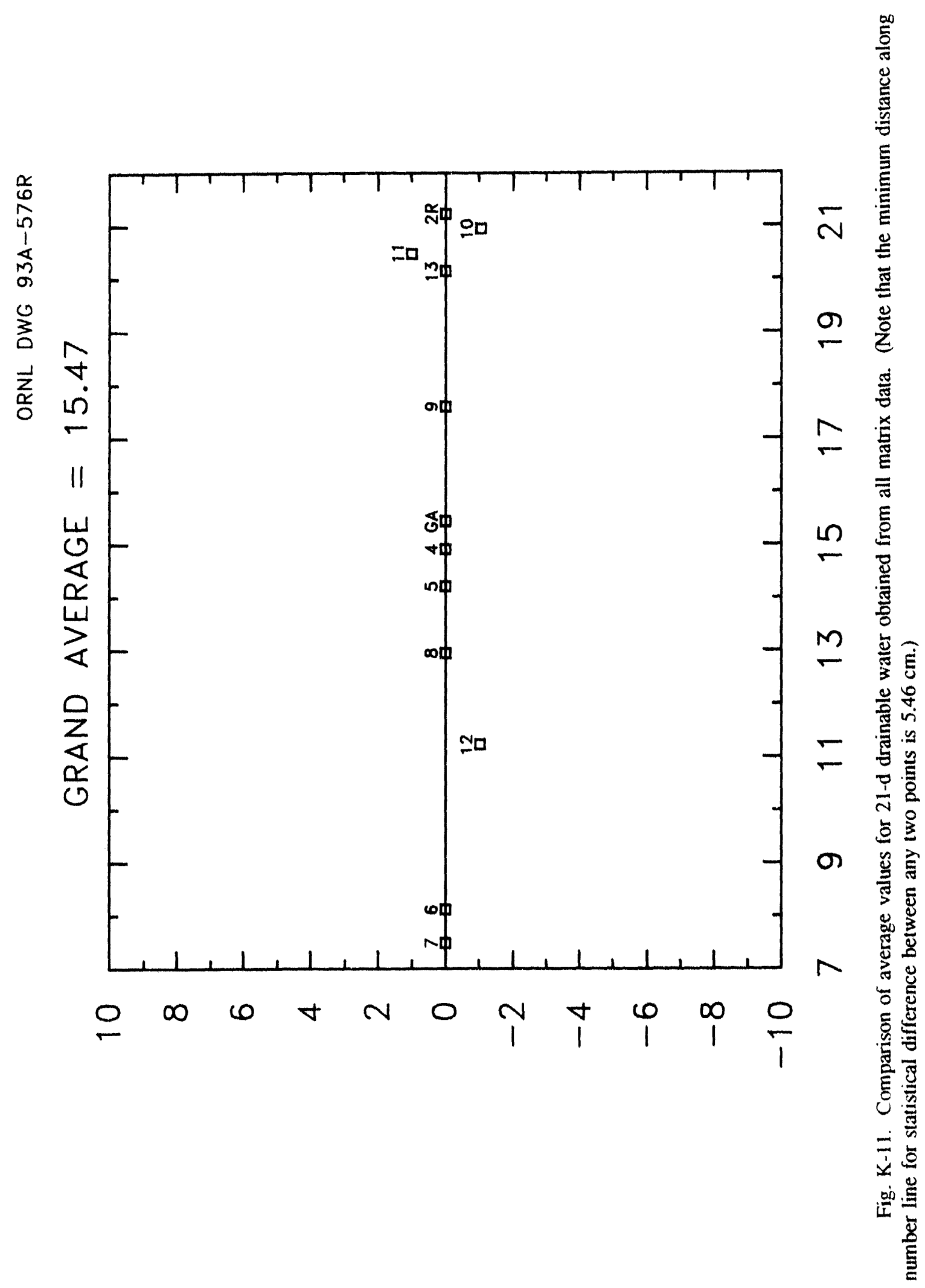




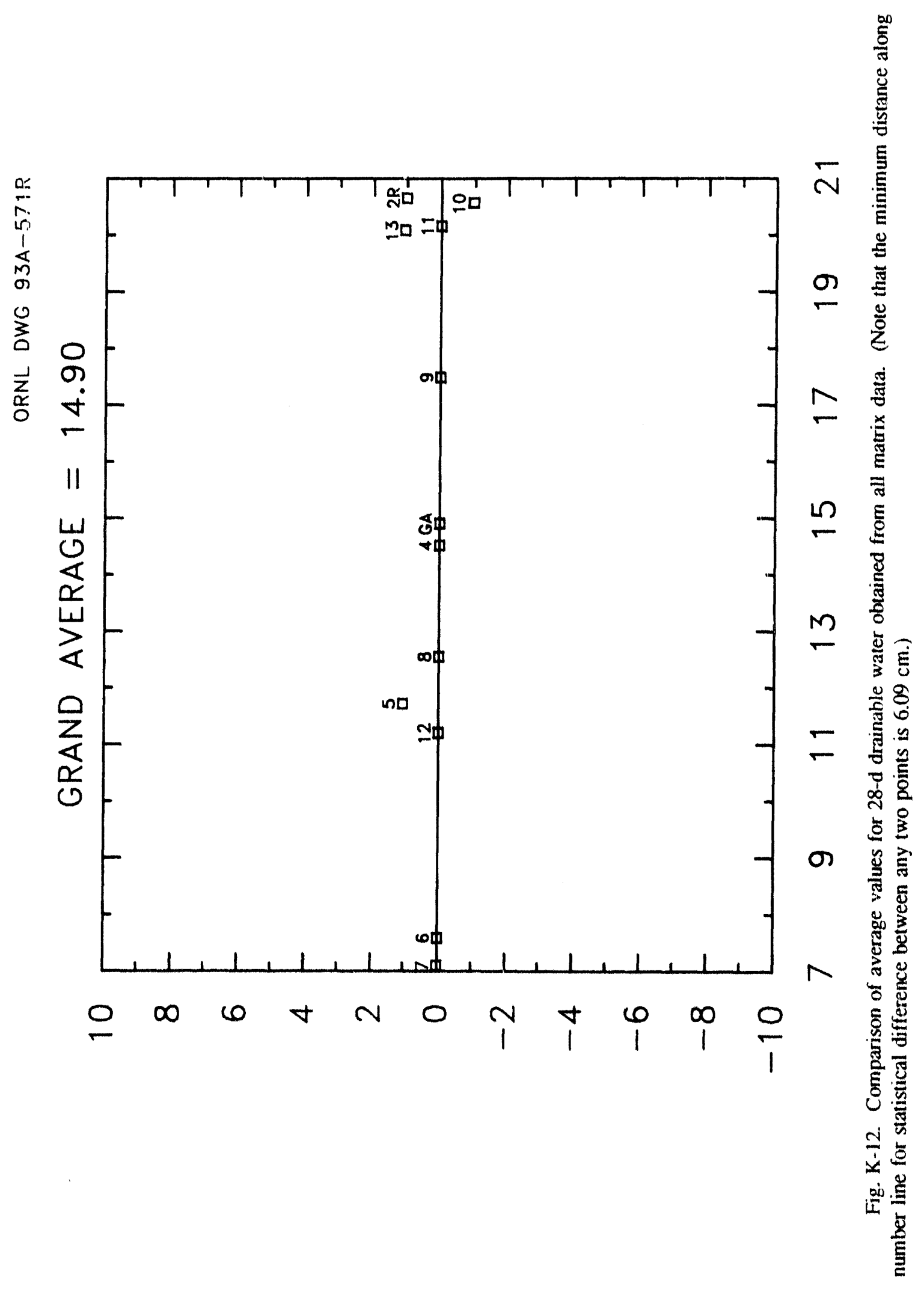




\section{INTERNAL DISTRIBUTION}

$\begin{aligned} \text { 1. } & \text { I. Beaty } \\ 2 . & \text { J. B. Berry } \\ 3 . & \text { W. D. Bostick } \\ 4 . & \text { C. H. Brown } \\ 5 . & \text { A. G. Croff } \\ 6 . & \text { G. D. Del Cul } \\ 7 . & \text { T. L. Donaldson } \\ 8-12 . & \text { C. L. Francis } \\ 13 . & \text { W. Fulkerson } \\ 14 . & \text { R. K. Genung } \\ 15-19 . & \text { T. M. Gilliam } \\ 20 . & \text { H. W. Godbee } \\ 21 . & \text { H. M. Henson } \\ 22 . & \text { J. R. Hightower } \\ 23 . & \text { E. K. Johnson } \\ 24 . & \text { R. L. Jolley } \\ 25 . & \text { K. H. King-Jones } \\ 26 . & \text { C. R. Kirkpatrick }\end{aligned}$

\author{
27. A. P. Malinaukas \\ 28. E. W. McDaniel \\ 29. I. L. Morgan \\ 30-34. S. C. Osborne \\ 35. S. M. Robinson \\ 36. M. K. Savage \\ 37-41. T. C. Scott \\ 42. J. L. Showmaker \\ 43. R. D. Spence \\ 44. O. K. Tallent \\ 45. D. R. Trotter \\ 46. J. H. Wilson \\ 47. Central Research Library \\ 48. ORNL Y-12 Technical Library \\ Document Reference Section \\ 49. Laboratory Records - RC \\ 50-51. Laboratory Records \\ 52. ORNL Patent Section
}

\section{EXTERNAL DISTRIBUTION}

53. J. J. Barich, U.S. Environmental Protection Agency, 1200 Sixth Avenue, Seattle, Washington 98101

54. J. Bradford, EG\&G Idaho, Inc., P.O. Box 1625, Idaho Falls, Idaho 83415-2109

55. K. C. Burgard, Westinghouse Hanford Company, P.O. Box 1970, Richland, Washington 99352

56. J. Cwynar, West Valley Nuclear Services Company, Inc., P.O. Box 191, West Valley, New York 14171-0191

57. T. T. Holmes, U.S. Army Corps of Engineers, Waterways Experiment Station, P.O. Box 631, Vicksburg, Mississippi 39180

58. A. J. Johnson, EG\&G Rocky Flats, P.O. Box 464, Golden, Colorado 80402-0464

59. C. A. Langton, Westinghouse Savannah River Company, P.O. Box 616, Aiken, South Carolina 29802

60. J. W. Liskowitz, Institute for Hazardous and Toxic Waste Management, New Jersey Institute of Technology, Newark, New Jersey 07102

61. R. O. Lokken, Battelle, Pacific Northwest Laboratorics, Battelle Boulevard, Richland, Washington 99352

62. G. Riebling, Westinghouse Hanford Company, P.O. Box 1970, Richland, Washington 99352

63. S. K. Rutherford, Westinghouse Environmental Management Company of Ohio, P.O. Box 398704, Cincinnati, Ohio 45239-8704

64. G. W. Veazey, Los Alamos National Laboratory, P.O. Box 1663, MS E524, Los Alamos, New Mexico 87545

65. J. H. Westsik, Jr., Battelle, Pacific Northwest Laboratories, Battelle Boulevard,Richland, Washington 99352 
66. C. C. Wiles, Risk Reduction Engineering Laboratory, U.S. Environmental Protection Agency, 26 West Martin Luther King Drive, Cincinnati, Ohio 45268

67. Office of Assistant Manager, Energy Research and Development, DOE-ORO, P.O. Box 2001, Oak Ridge, Tennessee 37831

68-69. Office of Scientific and Technical Information, P.O. Box 62, Oak Ridge, Tennessee 37831 

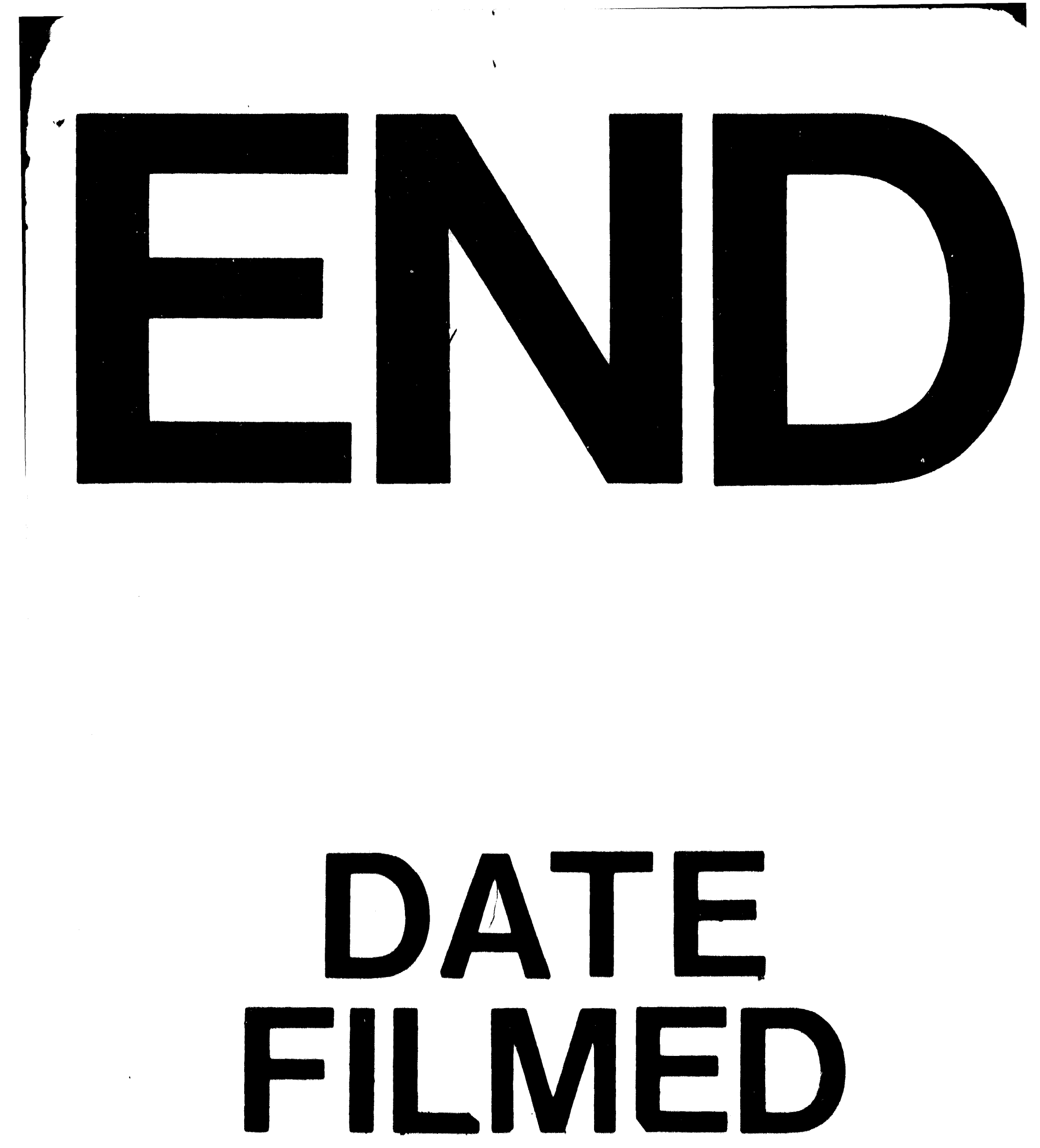

$$
12 / 16 / 93
$$




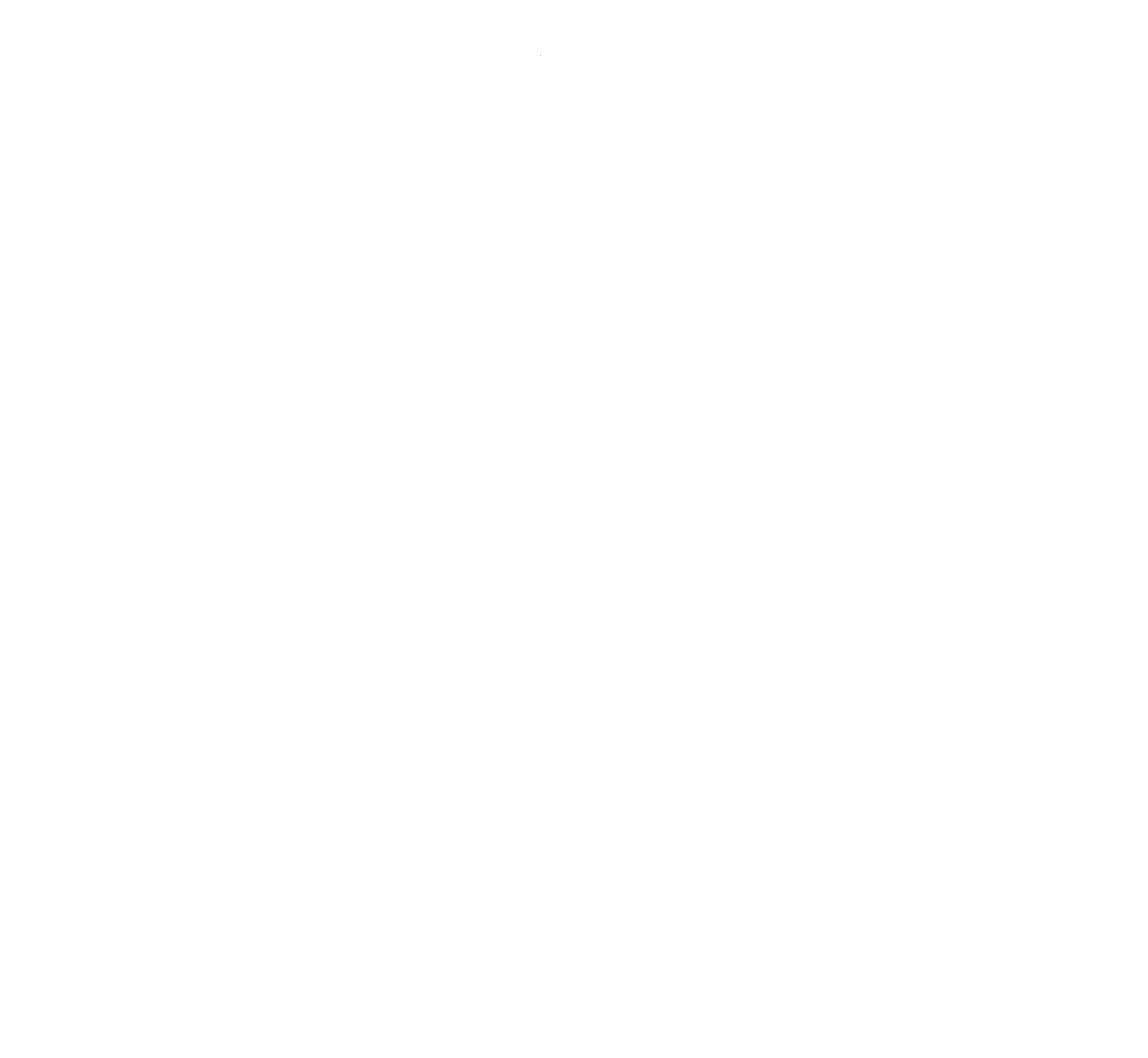

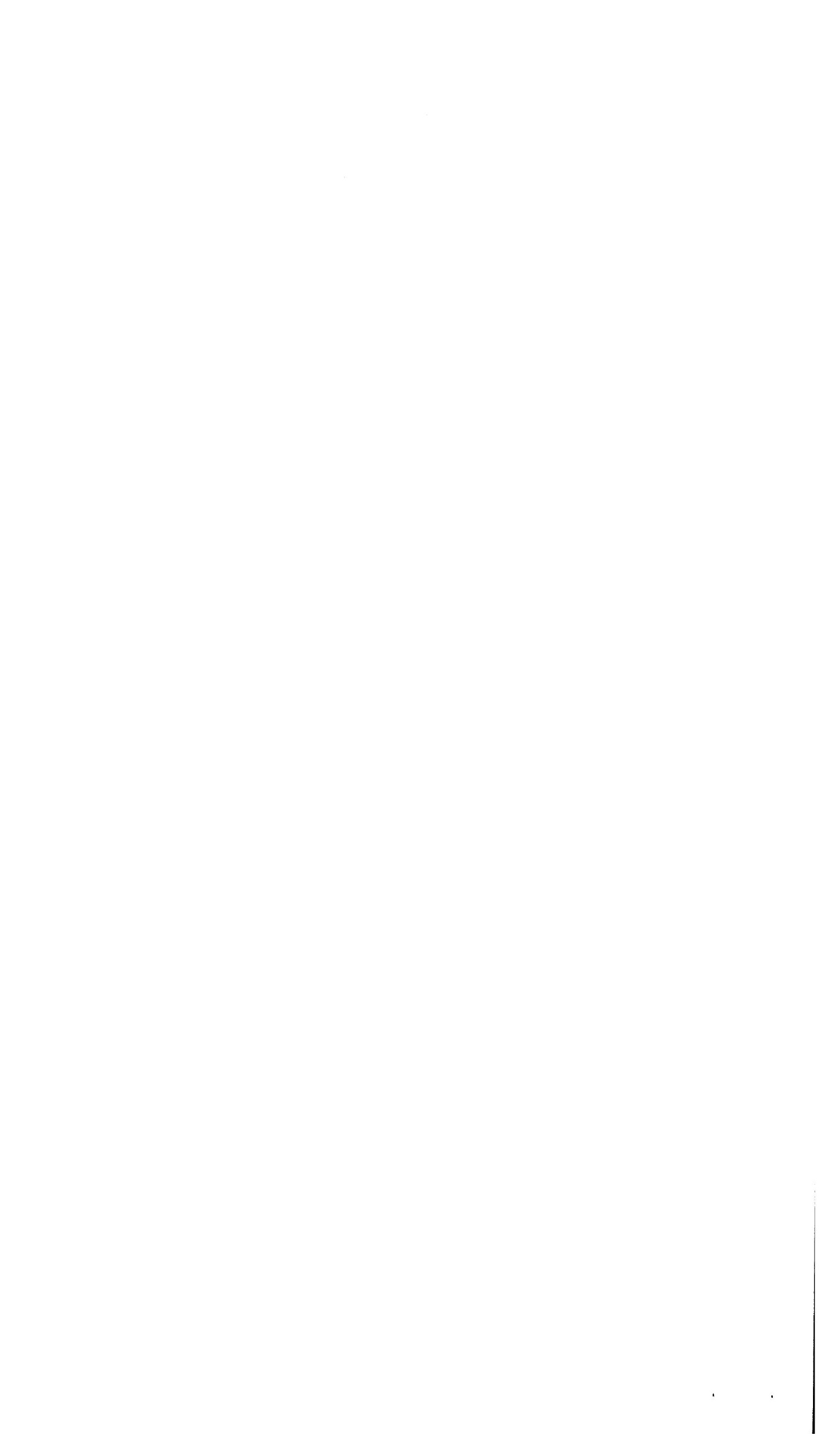

